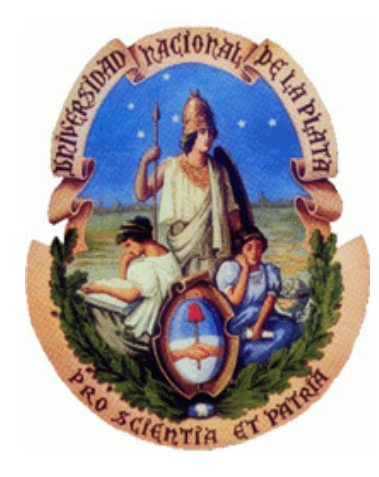

UNIVERSIDAD NACIONAL DE LA PLATA

FACULTAD DE PERIODISMO Y COMUNICACIÓN SOCIAL

Tesis realizada como requisito para optar al título de MAGISTER EN PERIODISMO Y MEDIOS DE COMUNICACIÓN

Título: Tinta verde. El modelo sojero en la prensa argentina.

\author{
Autor: Muchutti Arévalo, Claudia Andrea \\ Director: Lutczak, Oscar
}

Finalizada el 10 de mayo de 2015. 
Dedicado a quienes defienden la soberanía alimentaria, a quienes producen respetando la naturaleza, a los desplazados de sus tierras por el avance de la frontera agropecuaria y a los afectados por el uso irresponsable de agroquímicos. A ellos, mis innumerables horas de estudio y mi contribución al necesario debate sobre el modelo productivo sojero, desde el análisis mediático. 
Mi mayor agradecimiento es a mi director de tesis, el profesor Oscar Lutczak por haberme guiado y acompañado en la realización de este estudio. Probablemente, en Buenos Aires jamás lleguen a comprender lo dificil que es encontrar en el Nordeste un profesor que oriente a tesistas de posgrado en el ámbito del periodismo y lo gratificada que puede llegar a sentirse una estudiante cuando en medio de un viaje al caluroso Machagai, en pleno corazón chaqueño, el experto en análisis en discurso acepta brindar su ayuda. Mi deuda intelectual también es con el cuerpo de docentes de la Maestría y muy especialmente con César "Tato" Díaz por haber puesto en mi camino al gran Arturo Jauretche -en un seminario al que fui casi por obligación para poder presentar la tesis-, el pensador nacional que no se enseña en la Escuela y cuyo legado en defensa de la soberanía nacional continúa vigente, aún 40 años después de su muerte.

Mi gratitud a los compañeros de las cohortes 2008, 2009 y 2010 con quienes pude aprender desde una mirada federal y latinoamericana. Sin dudas, fueron el valor agregado de la maestría que ninguno en el grupo imaginaba encontrar.

Mi último agradecimiento- y no por eso el menos importante- es a mi familia: Oscar, Lussi, Tana, Ricardo, Rodri, Fito y Ana por ayudarme a cumplir el sueño de estudiar Periodismo en la Universidad Nacional de La Plata. 
"A la mañana temprano, entre mate y mate, el lector argentino lee el diario. Y más que para leerlo lo hace para descifrar el acertijo ¿qué quieren decir?, ¿quién los paga?, ¿adónde van?, ¿qué se proponen? Y uno a uno va resolviendo los problemas. Porque leer los diarios es más divertido que sacar palabras cruzadas. Es sacar la intención escondida y el interés venal. ¿Será el mate, con sus pausas meditadas, el que nos salva de la trampa con el hábito de la reflexión que lo apareja? ¿Será el mate, que nos ha dado este otro mate que nos defiende de la mentira organizada? Tome otro mate, amigo, y siga leyéndolos y oyéndolos. Pero entre mate y mate piense. Con eso basta. Y al dejar el diario, o cerrar el dial, diga como en el carnaval: ¡Te conozco, mascarita!'”. Arturo Jauretche (1958:11). 


\section{ÍNDICE}

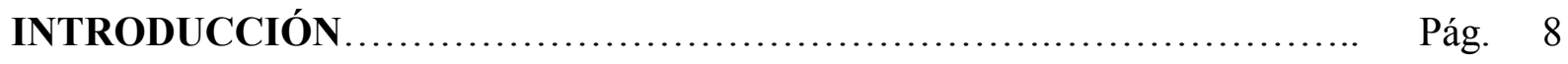

Justificación del tema........................................................ Pág. 8

Aportes......................................................................... Pág. 11

Presentación del problema................................................................. Pág. 12

Objetivos....................................................................... Pág. 12

\section{PRIMERA PARTE}

I.1. Marco Teórico/ Metodológico............................................... Pág. 14

I.2. El modelo productivo sojero: historia y características............................. Pág. 36

\section{SEGUNDA PARTE}

II.1. La rentabilidad del modelo agrosojero........................................ Pág. 50

II.2. Las patronales............................................................ Pág. 74

II.3. La política económica del Gobierno Nacional.................................. Pág. 94

II.4. Los controles de la Administración Federal de Ingresos Públicos (AFIP)........ Pág. 120

II.5. Organismos Genéticamente Modificados..................................... Pág. 136

II.6. Los silobolsas......................................................... Pág. 156

II.7. Los costos sociales del modelo agrosojero................................... Pág. 163

II.8. La tala de árboles....................................................... Pág. 177

II.9. La contaminación del medio ambiente...................................... Pág. 184

II.10. Los riesgos a la salud.................................................... Pág. 189

CONCLUSIONES ....................................................................... Pág. 205

PARA SEGUIR INVESTIGANDO ............................................... 228

APÉNDICE DOCUMENTAL ......................................................... Pág. 229

BIBLIOGRAFIA ........................................................................ Pán 230 


\section{Título}

Tinta verde. El modelo sojero en la prensa argentina.

\section{Palabras clave}

Análisis discursivo- modelo productivo sojero- prensa argentina.

\section{Resumen}

La investigación planteó como problema: ¿Cómo fue el tratamiento informativo sobre el modelo productivo sojero en las noticias construidas por los diarios La Nación y Página 12?

Sus principales objetivos fueron: Analizar cómo construyeron las noticias sobre el modelo productivo sojero argentino los diarios La Nación y Página 12. Reconocer qué estructuras y estrategias discursivas estuvieron implicadas en la expresión de la ideología de cada medio y con qué fin se las utilizó. Identificar las valoraciones efectuadas por cada diario en torno a los siguientes ejes temáticos: 1) La rentabilidad del modelo agrosojero. 2) Las patronales. 3) La política económica del Gobierno Nacional. 4) Los controles de la Administración Federal de Ingresos Públicos (AFIP). 5) Organismos Genéticamente Modificados. 6) Los silobolsas. 7) Los costos sociales del modelo agrosojero. 8) La tala de árboles. 9) La contaminación del medio ambiente y 10) Los riesgos a la salud.

El estudio aportó conocimientos sobre la soja y su construcción noticiosa en la prensa argentina. Entre otros aspectos pudo conocerse que en los diarios seleccionados existió un caudaloso flujo de información sobre el modelo productivo sojero en el periodo de agosto de 2013 a julio de 2014, pero el tratamiento informativo de las noticias construidas por cada diario fue disímil. En este sentido, puede señalarse que cada periódico diagramó y valoró los acontecimientos conforme principios editoriales que les permitieron organizar "la multitud de creencias sociales acerca de lo que sucede" (van Dijk, 2000).

El diario La Nación promovió en sus páginas el modelo hegemónico de producción agropecuaria argentina; es decir, el modelo sojero, basado en paquetes tecnológicos, semillas genéticamente modificadas, innovación en el sistema de labranza mediante la siembra directa, trabajo calificado y productos fitosanitarios; entre ellos, el glifosato. De igual modo, reprodujo las ideas de las instituciones nucleadas en la Mesa de Enlace, de las empresas multinacionales que elaboran eventos y variedades de semillas genéticamente modificadas y de las compañías encargadas de la exportación de cereales; haciendo eco de sus intereses de grupo y adhiriendo a sus reclamos. 
Además, la centenaria publicación omitió las luchas sociales de resistencia campesina e indígena que se suceden a lo largo del país debido al avance de la frontera agropecuaria. Mientras que Página 12 aborda el tema del modelo productivo sojero desde una mirada integral; informando sobre aspectos económicos, políticos, sociales, sanitarios y ambientales. El mismo periódico que en el rubro Economía reconoce la importancia que tiene para el país el ingreso de millones de dólares provenientes de los agronegocios; en el rubro Sociedad denuncia la existencia de conflictos sociales a causa del avance de la frontera agropecuaria e informa sobre casos de daños a la salud por el mal uso de productos fitosanitarios. Página 12 complejiza la realidad y tematiza sobre sectores vulnerables: campesinos que sufren el desalojo de "sus tierras", alumnos de escuelas rurales que fueron rociados con glifosato y vecinos de la localidad Islas Malvinas de Córdoba que se oponen a la instalación de una planta almacenadora de semillas. 


\section{INTRODUCCIÓN}

\section{Justificación del tema.}

En la década del `60, la soja era una rareza en la República Argentina y ocupaba un lugar marginal en su economía; por esos años, sólo existían cultivos experimentales con rindes insignificantes. Pero llegados los años `90, la expansión de la soja fue espectacular y la liberación de los cultivos transgénicos ${ }^{1}$ generó altos rindes. En 1993 la superficie sembrada alcanzó las 6 millones de hectáreas y en el 2000 superó las 10 millones. Hoy, la soja es el cultivo más importante de nuestro país con una superficie sembrada de 19,6 millones de hectáreas, según el promedio de las últimas tres campañas y una producción de más de 48 millones de toneladas. Según estimaciones de la Bolsa de Comercio de Rosario, se sembrarán 20,4 millones de hectáreas de la oleaginosa en 2014/ 2015 y se prevé una producción de 58 millones de toneladas. Los rindes obtenidos en los últimos años y los precios internacionales favorables, transformaron a la oleaginosa en el principal cultivo de la economía argentina. En 2013, la liquidación de divisas obtenida por la exportación de soja fue de USS 20.032 millones $^{2}$. "El modelo sojero ha contribuido con el logro de importantes superávit en la balanza comercial y fiscal necesarios para, entre otras razones, hacer frente al pago de los servicios de la deuda externa", señala Teubal, M. (2010).

Cabe señalar además, que nuestro país es el principal proveedor mundial de aceite de soja (exporta más de 4 millones de toneladas métricas al año) y harina de soja (19 millones de toneladas métricas al año), según datos del Centro de Exportadores de Cereales.

El auge de la oleaginosa en Argentina y en otros países se debe al gran impulso del gobierno de los Estados Unidos para promover el comercio de la soja a nivel mundial. La Asociación Americana de Soja ${ }^{3}$ se encargó de promocionar -a través de misiones técnicas internacionales- el reemplazo de la carne y leche de vaca por la "carne y leche de soja", explica Bravo, A. (2010). Pero el modelo agrosojero que por un lado, genera potencialidades económicas, moviliza una parte sustancial de las exportaciones y permite el ingreso de millones de dólares al país, es

\footnotetext{
${ }^{1}$ Cultivos modificados genéticamente para resistir el uso de herbicidas, desarrollados para la eliminación de hierbas y de arbustos. La primera semilla transgénica aprobada en Argentina fue la soja RR, en el año 1996, caracterizada por su resistencia al glifosato.

${ }^{2}$ Conforme datos del INDEC.

${ }^{3}$ La ASA agrupa a productores y otros sectores involucrados en el negocio de la soja en Estados Unidos.
} 
también el responsable de profundas consecuencias sociales y ambientales que pocos medios de comunicación se atreven a denunciar. La "sojización" de la frontera agropecuaria, concentrada históricamente en la Pampa Húmeda, hacia el Norte del país; en zonas tradicionalmente destinadas a la cría e invernada de ganado y a la producción de cultivos industriales como el algodón y el maíz. Este avance generó la tala de miles de hectáreas de monte nativo, el desalojo y represión de campesinos y pueblos originarios de sus tierras, el aumento de los cordones de pobreza en los pueblos y ciudades, la concentración y extranjerización de las tierras, la contaminación del medio ambiente por fumigaciones aéreas con glifosato, daños en la salud de la población por los agroquímicos y el encarecimiento de los alimentos que consumen las familias argentinas como consecuencia del monocultivo de exportación. Temas que son silenciados por la mayoría de los medios de comunicación para proteger los intereses de los sectores dominantes de la sociedad y que sólo salen a la luz en el rubro "Seguridad" cuando el avance sojero se cobra la vida de algún campesino que resiste el desalojo de su tierra.

El hecho de que un periódico ubique las noticias sobre la soja en una determinada sección o que se la evalúe en términos "positivos o negativos", se debe a que los medios, tal como señala Eliseo Verón, son dispositivos de producción de sentido (2001:14). Para este autor, lo que comúnmente llamamos actualidad es el "resultado de un proceso productivo" (1983: III), es un objeto que fue elaborado en "esa fábrica que es un medio informativo". "Los medios no copian nada (más o menos bien o más o menos mal), producen realidad social. Naturalmente medios hay muchos (diarios, canales de televisión, radios). De modo que hay muchos 'modelos de la actualidad'. Los distintos modelos de la actualidad están construidos para distintas audiencias”, explica Verón (ibidem).

Este estudio pretende analizar la construcción de noticias sobre el modelo productivo sojero que “fabricaron" -en términos de Verón- los diarios La Nación y Página 12, para el público al que están dirigidos. En la investigación se podrá observar cuáles son los argumentos a favor y en contra del monocultivo, a quién se le otorga la palabra, quiénes son los actores destacados y qué modelo de producción agrario propone cada diario.

\footnotetext{
${ }^{4}$ Entendida como un modelo de desarrollo agrario iniciado en la década del '90 y caracterizado por el uso de semillas genéticamente modificadas, siembra directa y glifosato, como se explicará más adelante.
} 
La "sojización" cuenta con "un aliado poderoso: los medios de comunicación corporativos que actúan como brazo comunicacional incondicional del agronegocio" a cambio de millonarias sumas en publicidad, denuncia la organización internacional GRAIN ${ }^{5}$. Y, explica que los mecanismos con que funciona esta alianza son: la ponderación de la agroindustria como panacea para la producción de alimentos; la cooptación del discurso del desarrollo sustentable a través de la propaganda; la negación de toda información sobre las luchas sociales de resistencia y los impactos ambientales; y finalmente, la estigmatización y criminalización de los movimientos y organizaciones sociales mostrándolos como subversivos o violentos.

También Pedro Peretti, ex director titular de la Federación Agraria Argentina (FAA), se pronuncia sobre la prensa y el modelo sojero. El productor se pregunta ¿cuándo aparecerá en los medios "lo que le cuesta al país este proceso de monocultivo inducido con concentración, vía migraciones rurales, cinturones de pobreza, inseguridad y salud? La pobreza rural nunca aparece, nunca dicen los miles de puestos de trabajo que destruyeron, las miles de chacras desaparecidas, los millones de compatriotas que se vieron obligados a migrar" (2013: 83-84 y 98). Afirma además, que deben ser pocos los nichos económicos que gasten más plata en lobby y publicidad que el sector sojero. Año tras año se invierten millones de pesos en publicidad -televisiva, gráfica, radial, online- propaganda, eventos, lunch, seminarios y expochacras, destinados a glorificar el monocultivo sojero.

\section{¿Por qué "Tinta verde"?}

Argentina es un país de fuerte tradición agropecuaria. Su principal actividad económica es la producción y exportación de alimentos. En este escenario, el periodismo agropecuario ocupa un espacio de importancia, a tal punto que la gran mayoría de medios de alcance nacional y provincial tienen segmentos o suplementos dedicados de manera específica a esta temática. También existen programas y canales de TV, revistas y sitios Web exclusivos sobre el agro. El auge de la soja en la década del '90 vino- de manera metafórica- a "teñir" la agenda de los medios argentinos, en general y de la prensa, en particular; en donde ocupa diferentes rubros

\footnotetext{
${ }^{5}$ Se trata de una institución sin fines de lucro que trabaja apoyando a campesinos y movimientos sociales en sus luchas por lograr sistemas alimentarios basados en la biodiversidad y controlados comunitariamente. Ver informe en: http://www.grain.org/es/article/entries/4739-la-republica-unida-de-la-soja-recargada
} 
conforme el enfoque de las noticias y los sistemas de clasificación de los diarios. De ahí el nombre "Tinta verde" que recibe este trabajo.

\section{Aportes.}

La investigación aporta conocimientos sobre la soja y su construcción noticiosa en la prensa argentina. A través de este estudio la sociedad puede conocer, entre otros aspectos, qué medios de comunicación impulsan el modelo hegemónico de producción agropecuaria y defienden los intereses económicos del sector agroexportador.

Mediante un análisis de las estrategias y estructuras discursivas se pudo revelar aquello que se encontraba implícito en los discursos de los diarios La Nación y Página 12 sobre el modelo productivo sojero. Teniendo en cuenta que los periódicos forman parte de la "arena de lucha" (de la que habla Bajtín) por la imposición del sentido y como señala Héctor Borrat (1989:10), cumplen un rol significativo como "actores políticos" cuyo objetivo esencial es influir en la opinión pública, ya que actúan como espacio de cristalización y significación social.

La originalidad del trabajo radica en que hasta el momento no existían estudios sobre la soja que sean abordados desde el campo del Periodismo, la Comunicación y la Semiótica. La mayoría de las investigaciones "clásicas" sobre la soja trabajan sobre aspectos técnico-científicos del cultivo y son abordadas desde las Ciencias Agrarias, con el objetivo de estudiar el manejo de la planta, sus enfermedades y la eficiencia en cosecha y postcosecha.

Por otra parte, en lo personal, como integrante del equipo de Comunicación Institucional del Servicio Nacional de Sanidad y Calidad Agroalimentaria (Senasa) este estudio aporta información cualitativa sobre el tratamiento periodístico del modelo agrosojero en dos diarios de alcance nacional que forman parte de los públicos con que se relaciona el organismo sanitario. Sus resultados brindan elementos para comprender la valoración positiva/ negativa que realizan las empresas periodísticas respecto de un modelo agrario exportador que impacta en la alimentación de la población nacional e internacional y al que algunos sectores contraponen con la Soberanía Alimentaria ${ }^{6}$.

\footnotetext{
${ }^{6}$ Según la Federación de Organizaciones Nucleadas en la Agricultura Familiar, la Soberanía Alimentaria se define como el derecho de los pueblos a la producción de alimentos sanos y nutritivos, producidos en forma sustentable y ecológica, accesibles y culturalmente adecuados. Postula, además, la libre decisión de los pueblos sobre cómo
} 
Sus resultados serán ampliamente difundidos en el ámbito académico, en congresos relacionados con el tema y en la revista de investigación científica "sns" del organismo sanitario, con fines de transferencia y extensión.

\section{Presentación del problema.}

En base a los presupuestos señalados, el siguiente problema guió la investigación: ¿Cómo fue el tratamiento informativo sobre el modelo productivo sojero en las noticias construidas por los diarios La Nación y Página 12 ?

El análisis abarcó el período comprendido desde agosto de 2012 a julio de 2014, coincidente con los meses de siembra y cosecha de la oleaginosa, respectivamente ${ }^{7}$. En agosto de 2012, el Ministerio de Agricultura, Ganadería y Pesca de la Nación, aprobó la comercialización en Argentina de Intacta RR2 $\mathrm{PRO}^{8}$, creada por la empresa Monsanto. Su llegada se produjo 16 años después de permitirse el uso de la primera generación de semillas modificadas genéticamente. En la campaña sojera 2012/ 2013 se registró una cosecha récord de 50,6 millones de toneladas de soja; $26 \%$ más que el bienio anterior. En este periodo también se dieron cotizaciones récords en la bolsa de Chicago por tonelada de soja a 549,04 dólares. Todos estos hechos han influido, en el recorte temporal de la investigación.

Para abordar el problema se trabajó con la definición de la "Construcción del acontecimiento" formulada por Eliseo Verón que desarrollaremos en el marco teórico.

Asimismo, en este trabajo, se entiende por "tratamiento informativo" a una serie de estrategias y estructuras discursivas que tienen que ver con el quehacer periodístico y que están implicadas en la expresión de la ideología que posee cada medio. El análisis de dichas estrategias y estructuras tendrá en cuenta las definiciones planteadas por Teun van Dijk, como veremos más adelante.

\section{La investigación tuvo como objetivos:}

- Analizar cómo construyeron las noticias sobre el modelo productivo sojero argentino los diarios La Nación y Página 12.

organizar la producción y el sistema alimentario poniendo en el centro de la escena a quiénes producen, consumen y distribuyen los alimentos por encima de las exigencias del mercado.

${ }^{7}$ Según el calendario de siembra y cosecha de cultivos del Instituto Nacional de Tecnología Agropecuaria (INTA).

${ }^{8}$ Resistente al glifosato con la producción de la toxina Bt. 
- Reconocer qué estructuras y estrategias discursivas estuvieron implicadas en la expresión de la ideología de cada medio y con qué fin se las utilizó.

- Comparar los discursos de cada medio y establecer semejanzas y diferencias en la construcción de noticias sobre la soja.

- Identificar las valoraciones efectuadas por cada diario en torno a los siguientes ejes temáticos: 1) La rentabilidad del modelo agrosojero. 2) Las patronales. 3) La política económica del Gobierno Nacional. 4) Los controles de la Administración Federal de Ingresos Públicos (AFIP). 5) Organismos Genéticamente Modificados. 6) Los silobolsas. 7) Los costos sociales del modelo agrosojero. 8) La tala de árboles. 9) La contaminación del medio ambiente. 10) Los riesgos a la salud.

- Indicar qué temas relacionados al monocultivo de la soja aparecieron con mayor asiduidad y cuáles fueron excluidos de la agenda de cada diario.

\section{Algunas aclaraciones para guiar la lectura de este análisis.}

El uso del formato "negritas" en las citas transcriptas de las unidades de análisis pertenecen a la autora del presente trabajo y fueron utilizadas para resaltar palabras o frases; las originales fueron quitadas.

Cabe señalar además, que en este trabajo se utilizará la denominación de Página 12 para la palabra silobolsas; salvo caso cuando se transcriban textuales de La Nación, en donde se denomina en forma separada "silos bolsas". De igual modo, se empleará la denominación UA para hacer alusión a las unidades de análisis.

En el Apéndice Documental que figura en un CD se encuentran las 60 unidades de análisis que forman parte de la investigación en dos tipos de archivos: PDF y JPG. 


\section{PRIMERA PARTE}

\section{I.1. MARCO TEÓRICO / METODOLÓGICO.}

Como ya se adelantó en la introducción, para abordar el objeto de estudio se utilizó la teoría de la “construcción del acontecimiento" que plantea Eliseo Verón (2002) y los trabajos de Teun van Dijk (2000 y 2003) en lo que respecta a su noción de "ideología” y al Análisis Crítico del Discurso (ACD).

En el libro "Construir el acontecimiento", Verón plantea que "los medios informativos son el lugar en donde la sociedades industriales producen nuestra realidad" y demuestra cómo cada medio construye la actualidad de acuerdo con el público al que se quiere llegar. El autor señala que los medios no copian nada sino que producen realidad social. Y así como hay distintos medios (diarios, canales de televisión, radios) también hay muchos 'modelos' de actualidad.

Para el semiólogo argentino, los diarios se diferencian en primera instancia por la manera en que estructuran el espacio discursivo dentro de cada página y en la organización del conjunto. El todo constituye la diagramación, la cual resulta de la combinación de dos modos de organización: el topográfico, que atañe a la presentación, la fragmentación y el relacionamiento de los espacios; y el taxonómico que tiene que ver con los sistemas de clasificación utilizados por cada diario para ordenar los acontecimientos del día.

Los criterios taxonómicos se clasifican en:

El rubro: en donde se ubica una clase de acontecimiento que el diario utiliza en forma regular. Por ejemplo: "Sociedad", "Internacionales".

La sección: se trata de una subclase de acontecimientos dentro de un rubro. Por ejemplo: "Educación", "Religión".

El seudorrubro o seudosección: se ubica una clase de acontecimientos que aparecen en el lugar de un rubro o sección pero es creado en función de un acontecimiento especial.

La articulación de lo topográfico y lo taxonómico; permite jerarquizar el acontecimiento dentro de lo actual, asignándole una importancia relativa, luego de clasificarlo dentro de un tipo.

En cuanto a la titulación, señala Verón que la mayoría de los diarios anuncian un acontecimiento; por ejemplo: "Accidente en el sistema refrigerante de una central nuclear en Estados Unidos" (Le Monde, 29 de marzo). Mientras que los semanarios enuncian situaciones: "Energía nuclear: lo que puede ocurrir en Francia” (Le Point, 9-15 de abril). 
“El semanario produce un discurso que está 'más allá' del acontecimiento singular”, plantea Verón (1981:180). En este caso no se tematiza la situación, sino que se la da por sabida y se alude a ella a través de alguna expresión que tenga relación.

Los titulares de los semanarios pueden estructurarse por un conjunto de operaciones a los que Verón llama: "efecto de reconocimiento", ya que a menudo el título utiliza una expresión existente dentro del campo cultural del lector. "Con el título, el semanario suscita ya una complicidad que recurre a la cultura de clase del lector", explica el autor (1981: 182).

Asimismo, se tomará como referencia "El análisis del 'Contrato de Lectura'. Un nuevo método para los estudios del posicionamiento de los soportes de los media" (Verón, 1985). En esta obra se plantea que el contrato de lectura es la relación que existe entre un soporte (texto) y su lectura. Este contrato funciona en un discurso a nivel de la enunciación, el cual concierne a las modalidades del decir. Mediante la enunciación, el discurso construye una imagen de aquél que habla (el enunciador), de aquel a quien se habla (enunciatario) y un nexo o relación entre ellos, conocido como el contrato de lectura.

El estudio del contrato de lectura implica todos los aspectos de la construcción de un soporte de prensa: la manera en que titula cada diario (títulos, subtítulos, copete, etc.), tipos de recorridos propuestos al lector, la ubicación, jerarquización y clasificación que realizan los diarios del hecho, las fuentes y citas que utiliza cada medio gráfico; las características que poseen las imágenes y fotografías; modalizaciones de compaginación, el tipo de lenguaje que se utiliza. y todas aquellas dimensiones que definan los modos en que el soporte constituye el nexo con su lector.

El contrato de lectura concierne también a la imagen, por lo que Verón realiza una clasificación de las fotos de prensa y de las revistas semanales:

La retórica de las pasiones: son imágenes de personajes marcados por la notoriedad (social, política, científica). En estas fotografías se muestra la expresión de la cara del personaje, las imágenes le han sido "arrancadas" al personaje, que "...ha sido sorprendido cuando su rostro expresaba un estado de espíritu, o una emoción”, explica Verón (1985).

En la foto pose, en cambio, el personaje ofrece su imagen al fotógrafo "un personaje que posa, trata de hacer ver no el accidente anecdótico sino su carácter. Por lo tanto, Paris Match transforma esta imagen en acontecimiento, en evento, lo que ella enuncia en tapa, es que esta 
semana, el personaje en cuestión habla en Paris Match, que está presente, aquí y ahora, para los lectores de la revista" (Ibidem).

Por otra parte, a fin de conocer el tratamiento informativo que realizan los diarios La Nación y Página 12 sobre el modelo productivo sojero se utilizará la técnica del Análisis Crítico del Discurso (ACD), propuesta por van Dijk. Definida como un "planteamiento especial dedicado a estudiar los textos y el habla" que "emerge de la crítica, la crítica semiótica, y en general, del modo sociopolítico consciente y oposicionista en que se investigan el lenguaje y el discurso". Gran parte de la labor del ACD se dirige a subrayar las ideologías que desempeñan un papel en "la reproducción de" o "resistencia" a la dominación o la desigualdad. Entre los objetivos del ACD hay un esfuerzo por descubrir, revelar o divulgar aquello que es implícito, que está escondido o que por algún motivo no es inmediatamente obvio en las relaciones de dominación discursiva o de sus ideologías subyacentes (van Dijk, 1997: 15-16-17).

Teun van Dijk define a las ideologías como las encargadas de organizar en las personas, como miembros de un grupo, la multitud de creencias sociales acerca de lo que sucede y les permiten actuar en consecuencia. Se definen como la base de las representaciones sociales compartidas por los miembros de un grupo (1999: 21).

Cabe destacar que esta investigación adoptó el concepto de ideología propuesto por van Dijk; dejando de lado el planteado por Eliseo Verón que entiende "la dimensión de lo ideológico como una dimensión analítica propia a todo discurso social. El concepto 'ideológico' designa no un tipo de discurso, sino una dimensión de todo discurso, a saber, aquella determinada por la relación entre las propiedades discursivas y sus condiciones de producción" (1980: 86). "Las ideologías también pueden influir en lo que se acepta como verdadero o falso, especialmente cuando dichas creencias son consideradas importantes para el grupo". Además, pueden tomar argumentos "a favor de, y explicaciones sobre, un orden social particular", asegura van Dijk (2000).

La hipótesis central de la que parte el autor es que para realizar un estudio de la manera en que se exhiben y reproducen las ideologías es necesario identificar y analizar las estructuras del discurso. Entre las que se encuentran: las figuras retóricas, las proposiciones, los tópicos, la lexicalización, lo implícito y lo explícito, las estructuras esquemáticas, la persuasión, etc. 
Figuras retóricas: son empleadas para dar o quitar énfasis a los significados en función de opiniones ideológicas. Desempeñan un papel importante en la manipulación ideológica, puesto que, por ejemplo, se pueden elegir metáforas para descalificar a nuestros enemigos, las comparaciones pueden utilizarse para atenuar nuestra culpa y la ironía para desafiar los modelos negativos de nuestro oponente.

Existe una gran variedad de figuras retóricas, por lo que sólo se mencionarán las que aparecen con más frecuencia en las unidades de análisis de este trabajo.

Imagen: es la representación de alguna cosa a la cual se la describe tal como si se la estuviera viendo.

Sinécdoque: consiste en designar una cosa con el nombre de otra, que es una parte de ella. Por ejemplo, el pan para designar a los alimentos.

Anáfora: es la repetición de la misma/s palabra/as al comienzo de una frase.

Eufemismo: consiste en la sustitución de una palabra por otra a la que se considera vulgar o de mal gusto. Por ejemplo, "conflicto bélico" por "guerra".

Antítesis: contrapone dos palabras o ideas de significado opuesto.

Antonomasia: es la utilización de un adjetivo que funciona como apelativo.

Hipérbole: es la exageración de los rasgos de una persona o cosa a la que se describe.

Personificación: es la representación de objetos inanimados como seres vivientes.

Asíndeton: se eliminan los nexos sintácticos -generalmente conjunciones- entre términos que van unidos, produciéndose un efecto de rapidez.

Polisíndeton: se repiten conjunciones para dar más expresividad a la frase.

Epíteto: es un adjetivo que se coloca delante de un sustantivo para expresar con mayor énfasis una cualidad.

Comparación: explica la semejanza entre dos ideas a través de un rodeo de palabras para decir algo con más fuerza, elegancia, atraer, impactar y fascinar al destinatario.

Ironía: da a entender lo contrario de lo que se dice.

Metáfora: se identifica un objeto con otro en virtud de una relación de semejanza pero suprimiendo el comparativo "como". Sirve para dar mayor énfasis a lo que se está diciendo y para mantener puntos de encuentro en el seno de determinado grupo social. 
Sinonimia: cuando dos o más términos se sustituyen en un mismo contexto sin alterar el significado del contexto.

Paradoja: une ideas contradictorias en un mismo pensamiento, el cual encierra una verdad. Aliteración: radica en la repetición de los mismos sonidos en una frase para producir sonoridad.

Estructuras esquemáticas. Otra propiedad de la ideología se basa en las estructuras esquemáticas globales o superestructuras que representan la forma global del texto y la conversación. Lo que aparece en la introducción, conclusión, apertura o cierre puede indicar importancia, relevancia o prominencia. "Resulta vital si la información está expresada en un titular o no (...) la información o la opinión negativa sobre las minorías puede aparecer así en el titular, y la información que es importante pero positiva sobre ellos, puede mantenerse (...) fuera de los titulares", explica van Dijk (2000: 338).

Las proposiciones. Quién es considerado el héroe o el villano, el victimario, o la víctima, qué roles deben ser enfatizados u ocultados; son cuestiones que en el discurso organizan la ideología. Persuasión. La ideología tiene también una función persuasiva, los hablantes intentan cambiar la mentalidad de los receptores de modo que sean coincidentes con sus creencias, intenciones y objetivos.

Tópicos. Un estudio de la ideología también comprende un análisis de los tópicos que trata el discurso. Los mismos están representados por (macro) proposiciones que pueden expresar opiniones e ideologías.

Según van Dijk, la ideología opera a partir de una estrategia global de comunicación denominada "cuadrado ideológico", la cual consiste en los siguientes movimientos:

1. Expresar/enfatizar información positiva sobre NOSOTROS.

2. Expresar/enfatizar información negativa sobre ELLOS.

3. Suprimir/des-enfatizar información positiva sobre ELLOS.

4. Suprimir/des-enfatizar información negativa sobre NOSOTROS.

Lo ideológico también se manifiesta en lo implícito y lo explícito. La información que está explícitamente aseverada puede enfatizar propiedades negativas de los otros o positivas del propio grupo. Mientras que lo implícito puede emplearse para suprimir o pasar por alto información negativa sobre el propio grupo. 
"Siguiendo el cuadrado ideológico, podemos suponer, como antes, que la información implicada no está explícitamente aseverada y, en consecuencia, no está enfatizada y, por lo tanto, será típicamente información que necesita ser ocultada en beneficio del hablante y del grupo propio", agrega van Dijk (2000: 335).

Ahora bien, un discurso puede expresar alguna información y obviar otra. Los discursos tienden a ser relativamente incompletos cuando hablan acerca del grupo o ideología al que alguien pertenece. Y presentar información excesivamente completa para reflejar negativamente a los otros grupos o positivamente a nosotros mismos. Ambos casos pueden afectar a los receptores ya se crean modelos distorsionados o incompletos de la realidad. Esto es lo que van Dijk denomina detalle o nivel de descripción.

Lexicalización. La ideología puede encontrarse también en las palabras escogidas para expresar un concepto. Como ilustra van Dijk, "el par 'luchador por la libertad' versus 'terrorista' es el ejemplo paradigmático de este tipo de lexicalización basado en la ideología".

Teniendo en cuenta el cuadrado ideológico los miembros del otro grupo pueden ser descriptos en términos neutros o negativos y los de nuestro grupo con palabras neutras o positivas.

Los gráficos. Para van Dijk las variaciones gráficas son tomadas como elementos fundamentales en la expresión de la ideología. El hecho de que una crónica aparezca en primera plana o en el interior de un periódico, a la derecha, arriba o abajo, con o sin fotografía, imágenes o en colores son elementos que influyen en la importancia o valor noticioso de determinados acontecimientos. "El juego discursivo" de Daniel Prieto Castillo (1999) es otra obra que aporta elementos para un análisis sobre el tratamiento informativo. Para este autor, todo discurso posee preferencia por ciertas estrategias, determinados recursos expresivos y términos por encima de otros y la inclusión de algunos temas. Esto sucede porque toda expresión discursiva posee una intención.

El trabajo realiza una descripción detallada sobre las "estrategias de fondo" del discurso; es decir, aquello que se quiere transmitir a los destinatarios, lo sepan o no los emisores. Las mismas comprenden:

Lo manifiesto y lo latente: lo primero alude al tema tratado y la manera en que se lo presenta y lo latente tiene que ver con la verdadera intención del discurso ${ }^{9}$.

\footnotetext{
${ }^{9}$ Como puede observarse, estos términos se corresponden con lo que van Dijk llama "explícito" e "implícito".
} 
Predicaciones: Mediante ellas se da determinada versión de una persona, de una situación, de una cosa; de manera positiva como negativa. Se predica mediante juicios, calificaciones o descripción de acciones. Se predica "por lo que decimos de algo o alguien; por lo que alguien dice; por lo que mostramos de algo o alguien", sostiene Prieto Castillo (1999: 90).

$\mathrm{Al}$ armarse un mapa de predicaciones, reagrupando todo lo que se dice de cada personaje o situación, se puede aclarar a dónde se dirige la intención del discurso.

Referencialidad: teniendo en cuenta que toda expresión discursiva es una versión, existen distintas formas de acercarse a un tema. Las versiones de alta referencialidad acercan lo más posible a un tema, mediante una adecuada cantidad de información o unos detalles precisos. La baja referencialidad está presente cuando la versión ofrece unas pocas notas de algo, con la intención de que con ellas se agote todo. Mientras que la distorsión referencial consiste en la inclusión de una información falsa, destinada a ocultar, mentir o distorsionar el tema. Cuando la información está organizada para que tengamos una idea contraria a lo que es o le sucede al tema al cual se alude.

Tipificaciones: con este recurso se reduce a alguien o algo a una estructura reconocible. A partir de una identificación se puede calificar o descalificar. "Cuando las tipificaciones se empobrecen y se cargan de emotividad, estamos ante estereotipos (don Quijote, Sancho)", formula Prieto Castillo (1999: 77). Cuando se tipifica no se entra en grandes detalles, sino que algunas notas permiten identificar a alguien sin esfuerzos.

Relaciones de armonía y de oposición: cuando todos concuerdan en una expresión discursiva y no hay conflicto alguno, se habla de relaciones de armonía. Mientras que las relaciones de oposición se dan cuando existe oposición y conflicto. Es necesario revisar por qué son presentadas ciertas oposiciones y quedan fuera otras. Las relaciones de oposición son una constante en los materiales de difusión colectiva, debido a que las relaciones sociales son conflictivas. Hay oposiciones clásicas que aparecen en todas las culturas: el bien y el mal, Dios y el Diablo, hombre y mujer, joven y viejo, civilización y barbarie, industrializado y no industrializado; entre otras. Todo se conjuga en los extremos, en la antítesis; no hay matiz alguno, no hay un puente entre los opuestos. Esta versión se refuerza en las versiones estereotipadas. "Cuando el recurso se reduce a un esquema que todo intenta abarcarlo e interpretarlo, los riesgos de un empobrecimiento están siempre presentes", señala Prieto Castillo (1999: 98). 
De igual modo, el autor señala que es importante preguntarse, ¿por qué este conflicto y no otro? y ¿por qué determinada solución y no otra? Teniendo en cuenta que la selección de los conflictos depende de la intención del emisor y de ciertas evaluaciones de los grupos destinatarios.

Lo dicho y lo no dicho: lo manifiesto y lo latente están en el discurso, en tanto que lo no dicho es algo excluido u ocultado, pero que incide sobre lo expresado. "Cuando alguien, por ejemplo, me habla de su niñez y excluye toda referencia a su padre, puedo leer algo en esa ausencia", ejemplifica el autor (1999: 77). Asimismo agrega, que si no poseemos datos como para reconocer lo que el discurso oculta o deja afuera, no se podrá tomar conciencia de esa ausencia. Por lo que resulta importante tomar el contexto en toda su complejidad.

La investigación de Prieto Castillo plantea también que existen "estrategias de superficie" que funcionan en el plano de la organización del enunciado; ya que cada frase posee un tipo de intención. Entre ellas se encuentran:

La universalización: es un juicio generalizado a todos los miembros de un grupo. Son ejemplos, "todos", "ninguno", "el hombre", "la mujer", "los indígenas". A través de estas formas pueden surgir versiones racistas o sexistas que se convierten en estereotipos más que peligrosos. En el discurso político, los adversarios son reducidos a unas pocas notas utilizándose todo tipo de universalizaciones.

La generalización: a partir de un caso se pueden sacar conclusiones y se generalizan a todos los casos semejantes.

Redundancia: se reiteran los temas con otras palabras a fin de insistir en algo.

Sentido de oportunidad: se utilizan palabras que cambian el sentido de lo que se está diciendo; por ejemplo, el empleo de un juego de palabras, un chiste, un apodo o un refrán popular.

Entre las estrategias de superficie, este autor sitúa a las figuras retóricas de la comparación, la metáfora, la antítesis y la sinécdoque, que ya fueron explicadas.

Según este autor, un discurso puede forzar una percepción única por parte de la gente mediante la “uniacentualidad significativa" y el "todo expresado". El primer concepto actúa por medio de redundancias, enfatizaciones, universalizaciones, hipérboles y busca dejar en los destinatarios una sola versión de un tema. Mientras que en "el todo expresado" el mensaje se cierra sobre sí mismo, está todo dicho y no hay más que agregar porque los destinatarios reciben una sobrecarga de información. 
Lo ideológico, para Prieto Castillo consiste en:

- lo que se predica de un sujeto.

- un modo de vida propuesto como válido.

- los modos de relacionarse y soluciones sociales que se hace vivir o adoptar a los sujetos del discurso.

- en la adopción de ciertas estrategias discursivas por encima de otras.

- se juega en las maneras de cerrar o abrir el discurso.

"Y, como toda expresión discursiva es una versión y toda versión implica un punto de vista, una perspectiva, y como todo punto de vista significa la enfatización de tales predicados en detrimento de otros, de tales relaciones sociales y modos de resolver la vida diaria en definitiva; y como todo se resuelve en una compleja trama de aceptaciones y rechazos, de esquemas positivos y negativos, de apoyos y oposiciones, no hay discurso que no tenga un carácter ideológico", sostiene Prieto Castillo (1999: 160).

Dentro de los estudios marxistas, el semiótico Mijaíl Bajtín plantea que "el área de la ideología coincide con la de los signos" y a todo signo pueden aplicársele criterios de una valoración ideológica (mentira, verdad, corrección, justicia, bien, etc.)

La palabra es el fenómeno ideológico por excelencia (...) "la misma representatividad de la palabra en cuánto fenómeno ideológico, su poder demostrativo, la claridad excepcional de su estructura sígnica bastarían para colocar a la palabra en el estudio de las ideologías”, plantea Bajtín (1929).

La palabra se encuentra acentuada ideológicamente y su sentido sólo se define plenamente por su contexto. Existen tantos significados de una palabra cuantos contextos haya en uso. Cuando el signo es objeto de múltiples acentuaciones se dice que está pluriacentuado.

Recapitulando a este autor, el profesor de semiótica Marcelino García (2004: 68) añade; "En cada momento histórico existe una constelación de temas (contenidos) expuestos a la atención pública en los que la sociedad deposita un acento valorativo, lo cual alude al horizonte social de una época y de un grupo dados: solo aquello que posea un valor social puede entrar en el mundo de la ideología, constituirse y consolidarse en él; por lo que el signo llega a ser la arena de la lucha (de clases) por la imposición de la valoración y acentuación ideológica que pretende el 
reconocimiento social y la legitimidad. Un aspecto importante del signo es su carácter multiacentuado, lo que le permite la confrontación de acentos sociales".

"El signo llega a la arena de la lucha de clases (...) donde se lucha por el discurso y no meramente a través de él”, formula Bajtín (idem).

Los diferentes grupos sociales luchan incesantemente por imponer un sentido en el lenguaje. El proceso generativo de los sentidos es dialéctico, "un sentido nuevo se revela en el viejo y con su ayuda, pero tan sólo para contraponérsele y para reestructurarlo" (Bajtín, idem).

Otro modelo de análisis discursivo que sirvió como base de esta investigación para describir el tratamiento periodístico es el planteado por Catherine Kerbrat Orecchioni en su libro "La enunciación de la subjetividad en el lenguaje". En este trabajo se explica que "toda unidad léxica es en cierto sentido, subjetiva, dado que las palabras de la lengua no son jamás otra cosa que símbolos sustituidos e interpretativos de las cosas" (1986: 91-92).

La autora reconoce que es imposible estudiar directamente el acto de la enunciación, por lo tanto, propone identificar y describir las huellas del proceso individual de producción en un enunciado lingüístico. Este trabajo tiene el objetivo de reconocer las marcas de la subjetividad del hablante en su discurso, marcas que se manifiestan primordialmente a través de los deícticos y de los subjetivemas. Según Orecchioni, existen diferentes categorías de adjetivos subjetivos:

Los adjetivos afectivos: enuncian una propiedad del objeto al que determinan y una reacción emocional del sujeto hablante frente a ese objeto. Implican un compromiso afectivo del enunciador: "el pobre hombre", "la vieja casa".

Los evaluativos no axiológicos: en esta clase se encuentran los adjetivos que, sin enunciar un juicio de valor, ni un compromiso afectivo del locutor implican una evaluación cualitativa o cuantitativa del objeto denotado por el sustantivo al que determinan". Esta clase se adjetivos posee un carácter gradual "el camino es demasiado largo", "bastante largo", "es muy largo".

Orecchioni parafrasea a Bally cuando señala que la norma es relativa al sujeto de enunciación: “Todo adjetivo en el grado positivo está cuantificado con relación a una unidad de medida que cada sujeto lleva en sí mismo... Una montaña es alta o baja según la idea que uno se hace de la altura de una montaña” (Bally, 1969: 196). 
Los evaluativos axiológicos: aplican a un sustantivo un juicio de valor, positivo o negativo. Mediante ellos se refleja la competencia ideológica del sujeto de la enunciación y se manifiesta una toma de posición a favor o en contra respecto al objeto denotado.

La presente investigación también ha sido influida por el trabajo: "Los estudios semióticos. El caso de la crónica periodística" de Ana Atorresi. En el capítulo III, titulado "Diferencias ideológicas y diseño en la construcción de acontecimientos" demuestra que el conjunto de los elementos que componen el diseño de una página de diario "funciona como una unidad capaz de definir, superponiéndose o complementándose con el elemento lingüístico, un modo característico de informar" (1996). La autora analiza los elementos paratextuales que se relacionan con el diseño de un periódico: composición o diagramación de la página, cromatismo, tipografía, titulación y fotografía.

Para Atorresi, la portada de un diario opera como "programa" que determina el recorrido de lectura de la publicación y desde aquí se pueden observar las primeras diferencias ideológicas entre los distintos medios.

La parte más importante y llamativa de la portada de un diario se ubica en la zona de la mitad hacia arriba y más importante aun es la parte superior izquierda que concuerda con la línea de indicatividad $^{10}$.

Otro aspecto fundamental del armado de la página de diario es el de la titulación. La importancia de una crónica se determina por el tamaño y la extensión del titular, factores a los que se suma el contraste entre la letra y el fondo. A través del aspecto de los titulares se pueden detectar diferencias ideológicas entre los medios.

Si un medio gráfico considera que un hecho deber ser construido como "el" acontecimiento del día, emplea el título desplegado o bandera que se caracteriza por ocupar todo el ancho de la página.

Los tipos de letras más conocidos en la diagramación periodística son: el romano, el abastonado, el itálico o bastardilla script, el manuscrito o, las variantes fantasía y el tipo máquina de escribir. El tipo máquina de escribir es empleado a veces, por Página/12, con connotaciones que sugieren que el diario forma parte del llamado "nuevo periodismo" (...). El tipo romano presenta "serif",

\footnotetext{
${ }^{10}$ Las convenciones de lectoescritura occidental determinaron que de acuerdo con la línea de indicatividad se lea de arriba hacia abajo y de la izquierda a la derecha.
} 
un elemento transversal en la terminación de la letra que sirve de adorno. El abastonado, por su parte, es de diseño simple y con líneas sin perfiles (se las llama “de palo seco"). El tipo itálico presenta una inclinación hacia la derecha, que imita a la escritura manual. Estos tres son los más habituales en la prensa, mientras que los "fantasía" (letras dibujadas) se usan en secciones especiales o avisos publicitarios.

Un titular con cuerpo catástrofe, ancho extendido y espesor extranegro, por ejemplo, sirve para expresar lo que el medio considera como un acontecimiento de gran magnitud.

En lo que respecta a las marcas del locutor que aparecen comúnmente en los textos periodísticos, se encuentran la ironía y a la ruptura de la isotopía estilística.

Mediante la ironía un hablante puede realizar dos afirmaciones a la vez, una de ellas literal y la otra sobreentendida. "Suele aparecer en los títulos de Página/12 y, en segundo lugar, de algunas secciones de Clarín y apunta a crear una complicidad con el lector en relación al enunciado sobreentendido" (Atorresi, 1996: 216). Los titulares irónicos "editorializan en la medida que expresan la opinión / interpretación del medio en torno del suceso en cuestión; el editorialismo político a partir del humor irónico es una de las constantes del nuevo periodismo", agrega Atorresi (1996: 217).

La ruptura de la isotopía estilística, por su parte, consiste en la irrupción del estilo que se venía empleando en el texto. "Página/12 suele desviar estilísticamente el relato periodístico hacia otros géneros discursivos (...) e incluye con frecuencia vocablos propios de la comunicación oral cotidiana, recurso también generalizado en Crónica” (Atorresi, 1996: 218).

Para analizar el papel que desempeñan las fotografías en las unidades discursivas se triangularán las clasificaciones propuestas por Thibault Laulan y Eliseo Verón.

Según Thibault Laulan ${ }^{11}$, la imagen posee tres usos, que no necesariamente aparecen separados:

Estético: la imagen se centra en sí misma, el valor proviene de la calidad y combinación de sus elementos.

Documental: la imagen se adhiere a la realidad, intenta reproducirla o señalarla en sus conexiones esenciales. La imagen que presenta grados de "documentabilidad" también presenta grados de "objetividad".

${ }^{11}$ En "El juego del discurso", de Daniel Prieto Castillo, pág. 165. 
Apelativo: la imagen está volcada hacia quien la percibe. Los elementos se combinan con el fin de impactar o involucrar al perceptor.

Jacques Durand, por su parte, propone una transposición de las figuras retóricas verbales a las imágenes. Así, la figura de oposición puede emplearse para contrastar imágenes de personas, ambientes y objetos.

La sinécdoque puede darse en una imagen que muestre un rostro, una mano, unos labios ya que se representa el todo a través de una parte.

En la hipérbole o exageración visual, los personajes u objetos aparecen en un tamaño fuera de lo normal y en la metáfora un elemento reemplaza a otro y tiende a enfatizarlo, por ejemplo, la paloma por la paz.

Un análisis del tratamiento periodístico también requiere el estudio de las citas y fuentes que aparecen en el discurso y el papel que desempeñan.

Se entiende por polifonía como la presencia de varias voces en un texto o enunciado. Según Atorresi, en la crónica aparecen dos clases de discursos referidos:

1. Los que pertenecen a los entrevistados (participantes, testigos, personalidades) y corresponden a la investigación que lleva a cabo el periodista.

2. Los pertenecientes a los informantes oficiales (voceros oficiales, fuentes policiales), los que conocen los hechos a partir de esa investigación fáctica.

Los diarios "populares" presentan mayor cantidad de declaraciones de testigos, incluso de personas relacionadas muy indirectamente con los hechos.

La prensa "seria", privilegia, en cambio, la voz de los organismos oficiales. Cualquiera sea la forma del discurso referido (directo, indirecto, narrativizado) implica un recorte y una selección de lo que dijo el otro y esto conlleva una marca ideológica, señala Atorresi.

Para analizar la función que cumplen las citas en cada discurso se tendrá en cuenta el trabajo elaborado por la profesora de semiótica Sandra Savoini, "La inclusión de la palabra del otro en el discurso informativo" (2004).

Aquí, se esboza que la alusión a las fuentes y la inclusión de citas buscan producir un efecto de realidad y hacer creer en la verdad de lo que se está diciendo. 
En las citas indirectas, hay una subordinación de la segunda fuente a la primera mediante una integración gramatical en la que se cambian deícticos, tiempos verbales y las personas, manteniendo estable sólo el contenido semántico del discurso citado.

El discurso directo inserta la palabra de otro en un discurso, pero manteniendo su independencia y conservando sus marcas. Provoca el efecto de verdad y traslada la responsabilidad de lo que se dice a otro.

La cita mixta integra los dos estilos anteriores (directo e indirecto) y la narrativizada es una cita en estilo indirecto donde se borran las diferencias entre la voz citada y la citante.

Algunas funciones de la cita:

- Difundir la palabra del otro para expresarse uno mismo, pero sin mostrar que fueron proferidas por otro.

- La cita autoridad: los enunciados se producen en función de la persona que habla, ya que su voz está autorizada.

- Cita prueba: sirve para sostener "probar" lo que se dice. El cronista narra un hecho y lo ratifica con la palabra del otro.

- Citas implícitas: se introduce la palabra ajena para refutarlo o bien respaldar las propias opiniones.

- Las citas con fines irónicos o polémicos.

Cabe señalar que las palabras o expresiones entrecomilladas pueden ser empleadas con dos finalidades:

1. pueden funcionar como una cita textual o un estilo directo.

2. pueden funcionar indicando distancia respecto de lo dicho.

En cuanto a las fuentes informativas, se tomará como referencia la clasificación que propone Lucrecia Escudero en su libro "Malvinas el gran relato". En primera instancia existen los medios de comunicación (televisión, radios, periódicos) que poseen un alto nivel de legitimidad porque tienen como soporte de veridicción el circuito mediático.

Las fuentes textuales institucionales oficiales son miembros de instituciones del poder político y social (presidentes, ministros, diplomáticos, etc.).

Con el nombre de fuentes oficiosas se designa a aquellos actores cuya identificación es imprecisa, ya sea porque mantienen el anonimato o porque la información brindada no es 
fácilmente verificable y puede dar paso a los rumores. Estas fuentes son conocidas como "off de récord" y se dividen en fuentes textuales oficiosas activas y pasivas. Las primeras presentan un grado de identificación aceptable que las inscribe en un universo referencial específico, como por ejemplo, los militares, los políticos o los diplomáticos. Mientras que las fuentes oficiosas pasivas son impersonales porque no explicitan su origen y se representan por expresiones del tipo: "los observadores sostienen que".

"Esta caracterización de las fuentes oficiosas pasivas señala un doble movimiento enunciativo que está presente en la forma en que el diario concibe el dar la información: por un lado éstas actualizan la modalidad del "deber" - el periódico debe recoger todas las versiones, aun aquellas que no pueden ser confirmadas -, pero al mismo tiempo estas fuentes permiten publicar la dimensión de lo que está en "secreto" como modalidad informativa.

"El recurso a estas fuentes textuales vuelve muy difícil la verificación de la información suministrada, pero al mismo tiempo arroja sobre la escena informativa datos y personajes con el objetivo de hacerlos circular", señala Escudero (1996:110).

Existen además agencias nacionales e internacionales, como Télam, D y N (Diarios y Noticias), NA (Noticias Argentinas), Reuters, ANSA, etc.

La función de las fuentes, es construir un espacio actual (las fuentes están allí y "hablan”) y real (las fuentes legitiman los hechos creando un efecto de veridicción).

\section{Metodología}

La investigación fue abordada desde el paradigma interpretativo ya que buscó comprender la producción de sentido realizada por los diarios La Nación y Página 12 sobre las noticias referidas al modelo productivo sojero.

El enfoque metodológico empleado fue cualitativo puesto que se pretendió llegar a una descripción del fenómeno estudiado. El modelo de análisis cualitativo "contempla la realidad de modo holístico, total, divergente, global (...) trata de comprender la realidad como un todo unificado" (Pérez Serrano, 1994: 104).

Según su finalidad, se realizó una investigación descriptiva, debido a que se buscó caracterizar un fenómeno a partir de variables o categorías. 
II.1. Universo y muestra. El universo de este trabajo está conformado por los periódicos nacionales La Nación y Página 12. Estos diarios forman parte de un mismo Género- $\mathrm{P}^{12}$, es decir, que son productos que se encuentran en una misma zona de competencia directa, que comparten cierta periodicidad, localización espacio-temporal y función informativa. Los criterios que influyeron en la elección de estos diarios fueron: la tirada -teniendo en cuenta que se trata de dos de los cuatro periódicos de mayor circulación a escala nacional-, la existencia de un tratamiento temático amplio, el carácter de vocero de la opinión pública y la trayectoria de cada medio.

Según Verón (2001:138), para dar cuenta de las condiciones productivas de un discurso se debe compararlo con otro discurso. Determinar cuáles son las propiedades que los caracterizan es determinar en qué son diferentes o similares uno del otro. "El análisis de los discursos sólo puede trabajar sobre las distancias interdiscursivas, es siempre interdiscursivo", señala el autor (ídem).

Es así, que en esta investigación se analizó la cobertura que hicieron los dos diarios nacionales mencionados, trabajando sobre las distancias interdiscursivas que permitieron identificar y comparar las construcciones de sentido en torno al acontecimiento.

Por otra parte, la muestra está constituida por las siguientes ediciones, desde agosto de 2012 a julio de 2014:

- Del diario La Nación: 25/08/2012, 12/10/2012, 03/11/2012, 09/02/2013, 16/02/2013, 27/02/2013, 28/02/2013, 21/03/2013, 22/03/2013, 25/03/2013, 26/03/2013, 30/03/2013, 19/04/2013, 27/04/2013, 28/04/2013, 02/05/2013, 03/05/2013, 04/05/2013, 10/05/2013, 15/05/2013, 18/05/2013, 01/06/2013, 07/06/2013, 01/02/2014, 25/01/2014, 03/02/2014, 04/02/2014, 27/02/2014, 05/03/2014, 14/03/2014, 28/04/2014 y 30/07/2014.

- Del diario Página 12: 14/08/2012, 22/08/2012, 05/10/2012, 07/10/2012, 16/10/2012, $12 / 11 / 2012$, 18/02/2013, 19/02/2013, 28/02/2013, 11/04/2013, 25/04/2013, 26/04/2013, $14 / 05 / 2013,20 / 05 / 2013,23 / 05 / 2013,10 / 06 / 2013,11 / 06 / 2013,12 / 06 / 2013,18 / 07 / 2013$, 20/08/2013, 05/09/2013, 18/11/2013, 23/11/2013, 31/01/2014, 07/02/2014, 21/02/2014, 08/04/2014, 15/04/2014 y 17/04/2014.

\footnotetext{
${ }^{12}$ Clasificación que hace Verón, para diferenciar productos, como ser periódico de información, revista femenina, revista científica, etc.
} 


\section{II.2. Selección de las unidades de análisis.}

Según Sergio Federovisky ${ }^{13}$, la soja no es un cultivo ni un producto de exportación sino un modelo; es decir, las formas que adquieren las relaciones de la sociedad, economía y naturaleza en un cierto momento histórico. "Un modelo o un sistema responde a un funcionamiento complejo, multivariable. Ese funcionamiento determina un escenario caracterizado por esa complejidad. Cuando se aíslan las consecuencias emergentes de ese escenario y se las analiza de manera lineal, se diluye la responsabilidad de 'el modelo' en la conformación de ese nuevo estadío", explica Federovisky (Le Monde diplomatique, edición 179: 8).

En base a estas definiciones y a fin de brindar un panorama completo sobre el objeto de estudio, abordarlo en su complejidad, organizar el análisis y efectuar comparaciones, se clasificó al corpus en 10 ejes temáticos: 1) La rentabilidad del modelo agrosojero. 2) Las patronales. 3) La política económica del Gobierno Nacional. 4) Los controles de la Administración Federal de Ingresos Públicos (AFIP). 5) Organismos Genéticamente Modificados. 6) Los silobolsas. 7) Los costos sociales del modelo agrosojero. 8) La tala de árboles. 9) La contaminación del medio ambiente. 10) Los riesgos a la salud.

Para el estudio, se seleccionaron 60 unidades de análisis (a las que denominaremos UA de aquí en adelante); 30 de La Nación y las restantes de Página 12. Cabe señalar, que no se trata de las únicas noticias sobre soja que se publicaron en ambos diarios en el período de estudio, pero a criterio de la investigadora resultan las más representativas respecto a los ejes temáticos y las que más elementos brindarán al análisis teniendo en cuenta los objetivos de la investigación. Las noticias que no se tuvieron en cuenta fueron consideradas menos significativas o reiterativas.

La muestra seleccionada no es probabilística; por lo tanto, la elección de las unidades no dependió de que todos tengan la misma probabilidad de ser elegidos, sino de la decisión de la investigadora. Es, además, intencional ya que sus unidades poseen características que se consideran podrían arrojar resultados significativos para el presente estudio conforme a los objetivos planteados.

A continuación figuran las UA, ordenadas conforme a los ejes temáticos, los periódicos que conforman la muestra y la fecha de publicación.

\footnotetext{
${ }^{13}$ Biólogo y periodista.
} 


\section{1) La rentabilidad del modelo agrosojero}

UA 1: "El ladrillo le gana al poder de compra de la soja 2012/2013” (La Nación, 09/02/2013).

UA 2: "La siguen cosechando con pala" (Página 12, 19/02/2013). UA 3: "Un doble impacto sobre el campo" (La Nación, 21/03/2013). UA 4: "Serán récord las cosechas argentinas de soja y de maíz” (La Nación, 22/03/2013). UA 5: “Granos gruesos con mayores rindes” (La Nación 30/03/2013). UA 6: “Advierten que se deteriora el poder de compra de la soja por la suba de los costos y la inflación” (La Nación, 19/04/2013). UA 7: “Mejor, imposible: la soja de 60 quintales" (La Nación, 27/04/2013). UA 8: "El precio de la soja subió por tercera rueda consecutiva" (La Nación, 10/05/2013). UA 9: “Alivio por los dólares de la soja” (Página 12, 14/05/2013). UA 10: "La soja sumó la quinta rueda alcista consecutiva en la Bolsa de Chicago" (La Nación, 27/02/2014). UA 11: "Dólares a granel y reservas en calma" (Página 12, 08/04/2014).

De un total de 452 noticias referidas a este eje temático y publicadas en el diario La Nación en el periodo de estudio, se seleccionaron 8 UA. Mientras que en Página 12 se elaboraron 37 noticias y se seleccionaron 3 .

\section{2) Las patronales}

UA 12: "La amenaza del lockout para presionar" (Página 12, 18/02/2013). UA 13: “Compromiso de los sojeros" (Página 12, 28/02/2013). UA 14: "Aumenta el malestar del campo con el gobierno" (La Nación, 21/03/2013). UA 15: "Rechazan los ruralistas la posible aplicación de la ley antiterrorista" (La Nación, 26/03/2013). UA16: "Nuevo lockout contra las retenciones" (Página 12, 12/06/2013). UA 17: "Abre las puertas con cosecha y quejas récord" (Página 12, 18/07/2013). UA 18: “La Rural también quiere pescar” (Página 12, 17/04/2014). UA 19: "Para el campo no hay avaricia en la venta de granos, sino prudencia" (La Nación, 01/02/2014).

En este eje temático se seleccionaron 3 UA de La Nación, de las 20 noticias publicadas y 4 UA de Página 12, de las 11 elaboradas.

\section{3) La política económica del Gobierno Nacional}

UA 20: “Los exportadores le darían a Moreno US\$ 1600 millones” (La Nación, 28/02/2013). UA 21: “Súper rindes en lotes de soja: de eso no se habla” (La Nación, 04/05/2013).UA 22: “Los dólares del campo quedaron en la mira oficial” (La Nación, 25/01/2014). UA 23: "Los 
responsables son los grandes" (Página 12, 31/01/2014). UA 24: Capitanich acusó a productores de 'amarrocar' la cosecha y dijo que se busca desestabilizar" (La Nación, 01/02/2014). UA 25: “Capitanich les pedirá a las cerealeras que liquiden más dólares” (La Nación, 03/02/2014). UA 26: “Cerealeras prometen aportar US\$ 6000 millones más” (La Nación, 04/02/2014). UA 27: "En la tercera reunión, se abrió la silobolsa" (Página 12, 07/02/2014). UA 28: “El próximo gobierno debe mejorar la relación con el campo', dijo Grobocopatel” (La Nación, 14/03/2014). UA 29: “Con excepción de la soja, el Gobierno no muestra signos de una década ganada" (La Nación, 28/04/2014).

De las 25 noticias elaboradas por el diario La Nación se seleccionaron 8 UA y de las 6 publicadas en Página 12, 2 forman parte de este análisis.

\section{4) Los controles de la Administración Federal de Ingresos Públicos (AFIP)}

UA 30: "La AFIP intensificó la presión a los productores de soja" (La Nación, 09/02/2013).

UA 31: "Los esclavos de la soja” (Página 12, 11/04/2013). UA 32: “A la caza de empresas fantasma" (Página 12, 26/04/2013). UA 33: "Por la cosecha de soja, la AFIP redobló el control en campos" (La Nación, 28/04/2013). UA 34: "El oscuro camino del cereal” (Página 12, 18/07/2013). UA 35: "Profundizan el control sobre la comercialización de la cosecha" (La Nación, 21/02/2014). UA 36: "Piedra libre a quienes se guardan la cosecha" (Página 12, 21/02/2014).

De las 19 noticias elaboradas por La Nación se seleccionaron 3 y de las 14 publicadas en Página 12, 4 forman parte de este estudio.

\section{5) Organismos Genéticamente Modificados}

UA 37: "La segunda generación de soja" (Página 12, 22/08/2012). UA 38: "La biotecnología vuelve a ser la mejor aliada" (La Nación, 25/08/2012). UA 39: "Destacan el papel de los transgénicos" (La Nación, 03/11/2012). UA 40: "La nueva soja que permite ahorrar hasta tres aplicaciones de insecticidas" (La Nación, 16/02/2013). UA 41: "La soja del futuro ya está en el país" (La Nación, 30/03/2013). UA 42: "Un día contra la multinacional" (Página 12, 23/05/2013). UA 43: "Una ONG ambientalista objeta una nueva semilla" (Página 12, 05/09/2013). UA 44: “Dos meses de bloqueo" (Página 12, 23/11/2013).

Para este estudio se seleccionaron 4 UA de La Nación, de las 15 noticias publicadas y 4 de Página 12, de las 9 construidas por el medio. 


\section{6) Los silobolsas}

UA 45: "Pocos dólares, mucha soja" (Página 12, 07/10/2012). UA 46:"Atacan silos bolsas y temen que sea para que el campo venda soja" (La Nación, 02/05/2013). UA 47: "La Rural ve la mano del Gobierno en el ataque a silos bolsas con soja" (La Nación, 03/05/2013).

De las 4 noticias elaboradas por La Nación, 2 fueron seleccionadas para el análisis y de las 6 publicadas por Página 12, 1 forma parte de este estudio.

\section{7) Los costos sociales del modelo agrosojero.}

UA 48: “Avance sojero" (Página 12, 14/08/2012). UA 49: "Denuncian el asesinato de un campesino" (La Nación, 12/10/2012). UA 50: "Denuncias de violencia contra campesinos" (Página 12, 16/10/2012). UA 51: "Un intento para frenar los ataques" (Página 12, 16/10/2012). UA 52: "Reclamos del otro campo” (Página 12, 17/04/2014).

La única noticia publicada por La Nación perteneciente a este eje temático en el período de estudio fue seleccionada para su análisis. Mientras que de las 7 noticias elaboradas por Página 12, se seleccionaron 3.

\section{8) La tala de árboles}

- UA 53: "Desmonte en zonas prohibidas" (Página 12, 12/11/2012). UA 54:"Las imágenes del desmonte" (Página 12, 20/08/2013). UA 55:"Desarrollaron un sitio para monitorear los desmontes" (La Nación, 30/07/2014).

De las 4 noticias construidas por Página 12, 2 forman parte de este estudio. Mientras que la única noticia publicada por La Nación fue seleccionada para su análisis.

\section{9) La contaminación del medio ambiente}

UA 56: "El delta del Paraná se está volviendo ingobernable" (La Nación, 01/06/2013). En el diario Página 12, no se encontraron noticias relacionadas con este eje temático en el período desde agosto de 2012 a julio de 2014. Mientras que la única noticia publicada por La Nación fue seleccionada para su análisis.

\section{0) Los riesgos a la salud}

UA 57: "Polémica por los transgénicos" (Página 12, 18/02/2013). UA 58: "La salud cercada de Avia Terai" (Página 12, 20/05/2013). UA 59: “Agrotóxicos pampeanos" (Página 12, 18/11/2013). UA 60: “La contaminación en las aulas” (Página 12, 15/04/2014). En el diario La Nación, no se encontraron noticias relacionadas con este eje temático en el período desde 
agosto de 2012 a julio de 2014. Mientras que de las 11 noticias construidas por Página 12, se seleccionaron 4 .

Tal como lo señala Verón, los periódicos comprenden numerosos tipos de discurso, de géneros y de subgéneros. En esta investigación se estudiará uno de ellos, el discurso de la información, dejándose de lado las opiniones y editoriales.

6.3. Recolección de datos. La investigadora trabajó con datos secundarios, que "han sido obtenidos por otros y llegan elaborados y procesados de acuerdo con los fines de quienes inicialmente los obtuvieron y manipularon. Como estas informaciones proceden de documentos escritos (...) damos a estos diseños el nombre de bibliográficos”, según plantea Sabino (1996: 95).

6.4. Técnicas de recolección de datos. La técnica del análisis de discurso permitió conocer cómo construyó cada diario las noticias sobre el modelo productivo sojero. Para Verón "el análisis de los discursos no es otra cosa que la descripción de las huellas de las condiciones productivas en los discursos, ya sean las de su generación o las que dan cuenta de sus efectos”. Se llama a las primeras condiciones de producción y, a las segundas, condiciones de reconocimiento. El análisis que se efectuó en esta investigación está centrado en la producción. Esto “implica buscar en el discurso (entendido como un fragmento de la Semiosis, relacionado con otros discursos, un producto de un proceso de producción de sentido que lleva las marcas que lo engendró) las huellas que son el soporte de operaciones discursivas que toman la forma de reglas (gramáticas) que definen las restricciones que operan en la generación de un tipo de discurso (informativo) o un Género-P (el diario, por ejemplo), aplicadas bajo ciertas condiciones."

Se utilizó además, la técnica del análisis crítico del discurso (ACD), propuesta por van Dijk, la cual se encuentra desarrollada en el Marco Teórico de la presente investigación.

6.5. Procesamiento y análisis de datos. Para realizar un análisis sistemático de los datos, se utilizó la técnica de Comparación Constante ideada por Barney Glaser y Anselm Strauss; y posteriormente, perfeccionada por ellos y otros investigadores. 
Cabe señalar que, para el desarrollo concreto del proceso de categorización del método comparativo constante se empleará el procedimiento práctico ideado por la Dra. María Teresa Sirvent, que emplea siete pasos:

1. Transcripción de todos los materiales empíricos disponibles (entrevistas, documentos, textos, etc.) en un cuadro de tres columnas:

- Registro $^{14}$

- Comentarios ${ }^{15}$

- Análisis ${ }^{16}$

2. Se debe conocer lo más completa y detalladamente el campo fenoménico que se va a estudiar. Para ello se deberá realizar una lectura detenida, profunda e intensiva de los materiales recogidos de la realidad.

3. Los incidentes llamativos deberán ser señalizados en el material, colocándoles un nombre, etiqueta, código o categoría que los identifique.

4. Se reconocen los temas recurrentes, identificando las categorías o grupos de categorías que se repiten con más frecuencia.

5. Se procede a fichar los temas recurrentes.

6. Se comparan los incidentes contenidos en las fichas buscando elementos comunes y no comunes.

7. Se escriben pequeños memorándums (memorias teóricas).

Durante el proceso comparativo habrá categorías que se podrán agrupar o integrar en una categoría más amplia.

Finalmente, el proceso comparativo se detiene cuando se llega a la "saturación teórica" de las categorías, esto se da cuando los datos analizados ya no producen información adicional sobre la categoría, con la cual identificar nuevas propiedades.

\footnotetext{
${ }^{14}$ Aquí hay que transcribir lo que se ha observado de la realidad, las preguntas y respuestas de una entrevista, etc.

${ }^{15}$ Destinada a la expresión de la subjetividad del investigador: allí se escriben las reacciones, emociones, preconceptos, sensaciones y valoraciones que le causa la realidad.

${ }^{16}$ Esta columna es completada más tarde, durante el tercer paso y subsiguientes.
} 


\subsection{EL MODELO PRODUCTIVO SOJERO: HISTORIA Y CARACTERÍSTICAS.}

El sector agropecuario argentino comenzó a sufrir profundas transformaciones en la década del 60 , cuando desde organismos internacionales como la ONU comenzaron a pronosticar que el aumento de la población mundial requeriría una mayor producción de alimentos. Se adoptó así, por una forma de producción a gran escala destinada a la exportación.

"La profundización del proceso de agriculturización, iniciado durante la primera modernización agraria en los años 60 y 70, encuentra en las últimas décadas su entronización con el crecimiento de la producción sojera. La 'sojización' resume las dinámicas que acompañan la recomposición de las formas de producción en el agro argentino", señalan Gras y Bidaseca (2010: 6).

La soja es una planta de la familia de las leguminosas que contiene sus semillas en vainas o chauchas como las lentejas, las arvejas y los garbanzos. El poroto, de un alto valor proteico, posee $83 \%$ de aceite y $17 \%$ de harina. Al extraerse el aceite queda como residuo una torta (pellets) utilizada para los alimentos balanceados de animales. Originaria de China, se extendió por todo el este asiático, convirtiéndose en un cultivo popular.

En nuestro país, el $20 \%$ de la producción de poroto se exporta en su estado natural y el resto se industrializa como harina y aceite. Más del $90 \%$ de estos productos se venden en el exterior, destinándose muy poco volumen al consumo interno.

Argentina es el principal proveedor mundial de aceite de soja (exporta más de 4 millones de toneladas métricas al año), seguido por Brasil (2,718 millones de toneladas métricas al año) y Estados Unidos (425 mil toneladas métricas al año). También es el primer exportador de harina de soja (19 millones de toneladas métricas al año), seguido por Brasil (14,792 millones de toneladas métricas al año) y Estados Unidos (4,690 millones de toneladas métricas al año) ${ }^{17}$.

Los principales promotores del cultivo, con la Asociación Americana de Soja a la cabeza, señalan que la oleaginosa es una solución para el hambre en el mundo pero la realidad indica que el $88 \%$ de la soja que se comercializa en el mundo se utiliza para la producción de aceite y el resto es empleado para combustible biodiesel en Europa y pasta para forraje ${ }^{18}$. De igual modo, los principales importadores de soja son China, Estados Unidos y la Unión Europea y no otros países con mayores índices de pobreza.

\footnotetext{
${ }^{17}$ Según un informe del año 2007 del Departamento de Agricultura de Estados Unidos (USDA), en BRAVO, A.; CENTURIÓN MERELES, H y otros; (2010: 13).

${ }^{18}$ Alimento para ganado.
} 


\section{Algo de historia.}

Los primeros cultivos de la soja en Argentina, datan de 1909 en la Estación Experimental de la Escuela de Agricultura y Ganadería de la provincia de Córdoba. En 1912, el entonces director de la institución, Adolfo C. Tonnelier, presentó un informe sobre las condiciones, factibilidad y posibilidades de desarrollo de una producción que en ese entonces se consideraba apta para el forraje.

En el año 1924, durante la presidencia de Marcelo T. de Alvear, el Ministerio de Agricultura a cargo de Tomás Le Bretón, importó variedades de semilla de soja provenientes de Europa a fin de determinar su adaptación en diversas zonas del país, lo que se traduce en un primer impulso estatal para incentivar el cultivo. En la década siguiente, la Refinería Río Segundo de Córdoba suministró semillas de soja a productores del lugar para abastecerse del cultivo y producir aceite, constituyéndose en un segundo estímulo, esta vez desde el ámbito privado.

En el año 1960, la superficie de hectáreas sembradas alcanzaba las 1014, al año siguiente aumentó a 10.260 y en 1962 se extendió más de 10 veces en relación a la campaña anterior, alcanzando las 21.110 hectáreas. Esto se debió a la creciente demanda internacional de aceites comestibles finalizada la Segunda Guerra Mundial y a la elaboración de productos alimenticios destinados a la ganadería en los países europeos.

El 5 de julio de 1962, Argentina exportó soja por primera vez en el buque "Alabama" portando 6.000 toneladas con destino al puerto alemán de Hamburgo. En los años siguientes, la Secretaría de Agricultura y Ganadería, el Instituto Nacional de Tecnología Agropecuaria (INTA) y las Universidades Nacionales promovieron la investigación del cultivo en un escenario caracterizado por la creciente demanda internacional de harinas.

En la década del 70, ocurrieron una serie de hechos que cambiarían la estructura productiva de nuestro país. En primer lugar, el calentamiento del Océano Pacífico a la altura del Ecuador provocó la disminución de las anchovetas peruanas. Esta especie de pescado era utilizada a nivel mundial para la producción de harina proteica- elemento indispensable para la industria de alimentos balanceados -y la soja se constituía como una alternativa. Por otra parte, en el año 1973 Estados Unidos tuvo una mala producción y cerró la exportación del cultivo. Esto ocasionó la elevación del precio de la soja y el aumento de su demanda a nivel mundial. 
Los entonces, secretario y subsecretario de Agricultura de la Nación, Horacio Giberti y Armando Palau ${ }^{19}$, respectivamente, vieron la oportunidad de impulsar el cultivo de soja en el país, pero faltaban semillas. Fue así como asesorados por el ingeniero agrónomo Ramón Agrasar se pusieron en contacto con universidades y empresas estadounidenses.

En octubre de 1974, dos Hércules del Ejército partieron a Estados Unidos para traer 40 toneladas $^{20}$ de variadas semillas de la oleaginosa que fueron sembradas en campos experimentales y de productores. A partir de allí se dio el crecimiento ininterrumpido del cultivo. Se pasó de 369.500 hectáreas sembradas en ese año, a 442.500 en 1975, llegándose a 2.100.000 en 1979, según datos de la Bolsa de Cereales y el Ministerio de Agricultura, Ganadería y Pesca de la Nación.

El otro gran salto de la soja se produjo el 3 de abril de 1996 durante el segundo gobierno del presidente Carlos Menem, cuando el secretario de Agricultura, Felipe Solá, autorizó mediante la Resolución 167 la introducción a la Argentina de la soja transgénica elaborada por la empresa biotecnológica Monsanto. Por ese entonces, Argentina poseía un marco económico e institucional caracterizado por políticas neoliberales, desregulación de los mercados y paridad cambiaria con el dólar.

El cultivo genéticamente modificado fue desarrollado por los genes RR (Roundup Ready) y Bt (Bacillus thuringiensis), el primero le provee resistencia a las aplicaciones del glifosato ${ }^{21}$, mientras que el segundo gen, previene el desarrollo de determinadas plagas o enfermedades del cultivo.

La nueva semilla dio paso al sistema de siembra directa que no requiere el desmalezado previo, ya que la fumigación con glifosato basta para matar todas las hierbas que crecen alrededor de la soja. El nuevo método permite reducir costos de producción en cuanto al combustible y mano de obra y evita la degradación producida por la agricultura intensiva. No obstante, Dabat y Paz (2012) aseguran que, si bien la siembra directa nació para resolver el problema de la conservación de suelos está siendo utilizada en exceso y su implementación a lo largo de varios años ocasiona la compactación del suelo y la consecuente pérdida de permeabilidad.

\footnotetext{
${ }^{19}$ Durante la presidencia de María Estela Martínez de Perón.

${ }^{20}$ Según el ingeniero del INTA Fernando Martínez (2010).

21 Herbicida de amplio espectro, desarrollado para eliminación de hierbas y arbustos.
} 
La difusión masiva de la siembra directa y los cultivos transgénicos no sólo estuvo a cargo de un grupo de empresas multinacionales lideradas por Monsanto, el Estado Argentino fue un actor fundamental en la promoción, investigación y desarrollo de las nuevas tecnologías para el agro, a través de distintos organismo públicos como el Instituto Nacional de Tecnología Agropecuaria (INTA), universidades nacionales y escuelas agronómicas. Otra institución, que se encargó de multiplicar la difusión tecnológica fueron los medios de comunicación a través de noticias, informes especiales y publicidades en los suplementos rurales de la gráfica, canales, revistas, programas de radio y páginas Web especializadas en el agro.

En la campaña 96/97 se sembró un 4\% de la superficie total con la nueva variedad de soja modificada genéticamente, en la campaña 98/99 llegó al 80\% y en 2001 al 90\% del área sembrada, según Barsky y Dávila (2008: 43).

La expansión vertiginosa de la oleaginosa transformó la estructura productiva de la agricultura en nuestro país que, de poseer una producción triguera a comienzos del siglo XX, que generaba el imaginario "del granero del mundo", pasó a tener una sojera en el XXI y generó nuevas formas de organización de la producción y comercialización de los productos.

Hasta la campaña 90/91 el trigo era el cultivo por excelencia con alrededor de 5,8 millones de hectáreas, mientras que la soja lo secundaba con 4,9 millones. En el siguiente año los cultivos se igualaron, como puede observarse en el Cuadro $\mathrm{N}^{\mathrm{o}}$ 1. La última campaña en la que el trigo superó a la soja fue la del 96/97, a partir del siguiente año la oleaginosa fue el cultivo por excelencia y ningún otro logró superarla hasta el momento.

\section{Cuadro No 1: Comparación entre la superficie sembrada de trigo y soja en Argentina.}

\begin{tabular}{|c|c|c|}
\hline PERIODO & TRIGO & SOJA \\
\hline $1990 / 91$ & $5.817 .300 \mathrm{Ha}$. & $4.939 .000 \mathrm{Ha}$. \\
\hline $1991 / 92$ & $5.007 .000 \mathrm{Ha}$. & $5.007 .000 \mathrm{Ha}$. \\
\hline $1992 / 93$ & $4.957 .500 \mathrm{Ha}$. & $5.320 .000 \mathrm{Ha}$. \\
\hline $1993 / 94$ & $5.658 .400 \mathrm{Ha}$. & $5.817 .490 \mathrm{Ha}$. \\
\hline $1994 / 95$ & $5.877 .600 \mathrm{Ha}$. & $6.011 .240 \mathrm{Ha}$. \\
\hline $1995 / 96$ & $5.880 .300 \mathrm{Ha}$. & $6.002 .160 \mathrm{Ha}$. \\
\hline $1996 / 97$ & $7.968 .000 \mathrm{Ha}$. & $6.669 .500 \mathrm{Ha}$ \\
\hline $1997 / 98$ & $6.000 .000 \mathrm{Ha}$. & $7.176 .250 \mathrm{Ha}$. \\
\hline $2000 / 01$ & $6.496 .600 \mathrm{Ha}$. & $10.664 .330 \mathrm{Ha}$. \\
\hline $2005 / 06$ & $5.222 .485 \mathrm{Ha}$. & $15.393 .474 \mathrm{Ha}$. \\
\hline $2008 / 09$ & $4.732 .205 \mathrm{Ha}$. & $18.032 .805 \mathrm{Ha}$. \\
\hline $2010 / 11$ & $4.574 .080 \mathrm{Ha}$. & $18.886 .634 \mathrm{Ha}$. \\
\hline
\end{tabular}

Fuente: datos de la Bolsa de Cereales y el Ministerio de Agricultura y Ganadería de la Nación. 
"La siembra de soja empezó como una actividad esencialmente de pequeños productores de la pampa húmeda, pero la "sojización", vino de la mano de un modelo de desarrollo agrario dictado por el neoliberalismo a principio de los '90, compuesto por semillas transgénicas, siembra directa y glifosato, que trajo aparejado una altísima concentración de tierras y rentas y por ende, la expulsión de miles de chacareros y puso al borde del nocaut a la chacra mixta, que fue el tipo de explotación que trajo tantos beneficios no solo al sector sino al conjunto del país", señala Peretti (2013: 34).

El crecimiento de la soja en el país, no es un hecho aislado en América Latina. En 2012 Argentina, Bolivia, Brasil, Paraguay y Uruguay sembraron 50 millones de hectáreas con soja; es decir, 500 mil $\mathrm{Km}^{2}$. Una superficie $150 \mathrm{mil} \mathrm{Km}^{2}$ mayor que la extensión de Alemania. Un “desierto verde" del tamaño aproximado del estado español, señala Juan Luis Berterretche ${ }^{22}$.

Luego de años de uso indiscriminado de glifosato, las malezas fueron adquiriendo resistencia al herbicida, fue así que las corporaciones biotecnológicas invirtieron millones de dólares en busca de semillas para suceder a la RR.

El 15 de junio de 2012, luego de 16 años de que la Soja RR1 se introdujera en Argentina, la presidenta Cristina Fernández de Kirchner informó que la empresa Monsanto realizaría inversiones en el país. Un mes más tarde, el ministro de Agricultura, Ganadería y Pesca de la Nación, Norberto Yahuar, anunció junto a ejecutivos de Monsanto la aprobación del uso comercial de una nueva variedad especialmente desarrollada para nuestro país y Brasil, la denominada INTACTA Roundup Ready (RR) 2 PRO con máxima tolerancia a la aplicación del glifosato y modificaciones en el poder del insecticida que combate a las tres lagartas principales que atacan a la oleaginosa.

El 91\% de las semillas de soja transgénica que se utilizan en el mundo, devienen de la biotecnología de Monsanto, que como propietaria de la patente INTACTA RR2 PRO, cobra regalías cuando el productor compra sus semillas.

La llegada del nuevo transgénico se produjo en un marco político e institucional distinto, de posconvertibilidad, con la presencia de un gobierno crítico al neoliberalismo imperante en los '90, que recurrió a medidas proteccionistas para regular la economía y que asumió un rol activo en aspectos sociales y educativos. Sin embargo, en lo que respecta al modelo agrícola, el

${ }^{22}$ En Ecoportal.net 
monocultivo de exportación sojera se ha consolidado debido a que la recaudación fiscal, vía retenciones, posee una fuerte dependencia de las exportaciones generadas por el agro.

Los críticos de la mega agricultura exigen la intervención estatal como único medio para revertir a largo plazo los efectos devastadores que ocasiona este sistema. En este sentido, Dabat y Paz (2013: 61) señalan que, "se vuelve cada vez más necesario y urgente que el Estado intervenga para evitar perjuicios económicos, a través de una adecuada rotación del uso del suelo, la promoción de las economías regionales y la diversificación de la producción agropecuaria para reducir el precio de los alimentos que conforman la canasta alimentaria interna. A su vez, para evitar perjuicios ambientales, debe garantizar la prohibición de avanzar más allá de la frontera agrícola sobre tierras ricas en flora y fauna irrecuperables y sobre poblaciones que no practican el cultivo de soja...".

El uso de transgénicos en la agricultura ha despertado un debate a escala global y su discusión es recurrente en las mesas de trabajo y reuniones ordinarias de la Organización de las Naciones Unidas para la Agricultura y la Alimentación (FAO). Desde el organismo internacional señalan que, "la biotecnología ofrece instrumentos poderosos para el desarrollo sostenible de la agricultura, la pesca y la actividad forestal, así como de las industrias alimentarias. Cuando se integra debidamente con otras tecnologías para la producción de alimentos, productos agrícolas y servicios, la biotecnología puede contribuir en gran medida a satisfacer, en el nuevo milenio, las necesidades de una población en crecimiento y cada vez más urbanizada"23.

Para la FAO, la biotecnología puede propiciar el desarrollo agrícola en los países en desarrollo y es una herramienta para ayudar a reducir el hambre y la pobreza en el mundo.

Una investigadora de la Universidad Nacional de La Plata (UNLP) que se inscribe en esta postura es la coordinadora de Proyectos de la Fundación REDBIO Internacional (FRI) de la FAO, Sandra Sharry. "Ningún trabajo científico serio ha probado que los alimentos derivados de organismos genéticamente modificados dañen la salud. Además, en la Argentina, son sometidos a muchísimos controles de bioseguridad y de ADN. Muchos analistas consideran que los alimentos con modificaciones en el perfil de nutrientes poseen un gran potencial, ya que permitirían reducir la incidencia de problemas relacionados con la salud", manifestó la profesora en una entrevista publicada en el diario HOY de La Plata (16/05/2004).

\footnotetext{
${ }^{23}$ En http://www.fao.org/biotech/fao-statement-on-biotechnology/es/
} 
De igual modo señala, "El desarrollo de procesos biotecnológicos es una ventaja para países del tercer mundo, más aún cuando los mercados son cada vez más competitivos en términos de producción y costos (...) Una estrategia de política de ciencia y tecnología en un país es fundamental. En Argentina este es un tema prioritario desde hace mucho tiempo. Además, el Gobierno aumentó el presupuesto para ciencia y tecnología",24.

\section{Aspecto económico.}

El agronegocio provee de divisas al país que permiten equilibrar las cuentas externas y elevar el Producto Bruto Interno (PBI). Como señalan Dabat y Paz (2012), "la fortaleza de la demanda internacional de soja generó un ingreso de dólares a la Argentina en los últimos 10 años que permitió superar la crisis del comienzo de la década pasada, dejar atrás la insolvencia fiscal y convertir el estrangulamiento externo en desendeudamiento externo".

En Argentina se cobra una tasa del 35\% por los derechos de exportación a la soja, comúnmente denominas "retenciones". La devaluación de la moneda nacional en el año 2001 y el aumento del precio internacional de la soja ocasionaron un fuerte crecimiento de la recaudación por derechos a la exportación.

El 11 de marzo de 2008, con el precio internacional de la soja en su mejor momento, el Gobierno nacional pretendió aumentar la recaudación por derechos de exportación de los cuatro principales cultivos (soja, trigo, girasol y maíz) mediante un esquema de retenciones móviles. Se dictó así la Resolución 125 que elevó las alícuotas promedio y estableció un sistema de ajuste automático ante variaciones en los precios internacionales. Ante esta medida, las organizaciones de productores rurales Sociedad Rural Argentina, Confederaciones Rurales Argentinas, Federación Agraria Argentina y CONINAGRO llevaron adelante una serie de medidas de protesta que culminaron cuando la Resolución fue anulada.

En el año 2009 se implementó el Fondo Federal Solidario (conocido como Fondo Sojero) por el cual, del total de dinero que recauda la Nación en concepto de retenciones a las exportaciones de soja, el 70\% es para el Gobierno Nacional y el 30\% para las provincias. De ese 30\%, un 70\% es para cada Gobierno Provincial y un 30\% para repartir entre todos los municipios que componen la provincia.

\footnotetext{
${ }^{24}$ Diario La Razón, Bolivia. 22/05/2005.
} 
Dicho dinero únicamente puede ser utilizado por los mandatarios provinciales y jefes comunales para la mejora o la construcción de infraestructura sanitaria, educativa, hospitalaria, de vivienda y vial; tanto en ámbitos urbanos como rurales, y no puede ser usado para brindar aumento o recomponer los salarios de los empleados públicos. En la actualidad, el fondo de la soja es uno de los principales recursos que tienen los municipios para hacer obras.

Durante la campaña 2010/ 2011, el complejo sojero aportó al Estado nacional 7.564,9 millones de dólares en concepto de impuesto a las exportaciones. Como detallan Dabat y Paz (2012), los números favorables permitieron financiar la Asignación Universal por Hijo, las nuevas jubilaciones, el aumento de presupuesto para educación, obras de infraestructura y vivienda, las políticas sociales en general, los subsidios en los servicios públicos, el aumento del presupuesto en educación, ciencia y tecnología, la recomposición salarial de los empleados públicos, el apoyo a la industria y la promoción a la economía social.

En el año 2013, el complejo oleaginoso representó un 36,9\% del total de las exportaciones de la Argentina, constituyéndose como el principal sector que origina el ingreso de dólares a la economía.

Según la Cámara de la Industria Aceitera de la República Argentina (CIARA) y el Centro de Exportadores de Cereales (CEC), el sector agroexportador liquidó U\$S 23.161,5 millones durante 2013 y U\$S 23.069 millones en 2012.

En el cuadro $\mathrm{N}^{\circ} 2$, se puede observar la importancia del complejo oleaginoso para la economía nacional en el marco de las exportaciones. De los 55.780,00 millones de dólares que ingresaron al país en 2007 en concepto de exportaciones, 13.602,00 millones corresponden a la soja.

En el año 2013, la soja representó un negocio de 20.032 millones de dólares, que equivale a lo que facturaron la industria automotriz y el petróleo juntos, según puede observarse en el cuadro $\mathrm{N}^{\mathrm{o}} 3$, que figura seguidamente.

El modelo sojero funciona a través de la implementación de un paquete tecnológico que requiere el uso de semillas modificadas genéticamente, innovación en el sistema de labranza (mediante la siembra directa), maquinarias precisas y automatizadas (cosechadoras y sembradoras electrónicas, sensores, balanzas, etc.), trabajo calificado (ingenieros agrónomos e industriales, biólogos, bioquímicos, etc.) y grandes cantidades de agroquímicos (herbicidas, pesticidas, fertilizantes, etc.). En este sentido, Dabat y Paz (2012) señalan que, "la masiva aplicación del 
paquete tecnológico en el ámbito agrícola generó un cambio holístico con repercusión en el aumento de los rendimientos de los cultivos".

Cuadro $\mathrm{N}^{\mathbf{2}}$ 2. Evolución de las exportaciones totales y de los complejos oleaginosos en Argentina, 1997-2007. En millones de dólares.

\begin{tabular}{|l|c|r|r|r|r|r|}
\hline & $\mathbf{1 9 9 7}$ & $\mathbf{2 0 0 3}$ & $\mathbf{2 0 0 4}$ & $\mathbf{2 0 0 5}$ & $\mathbf{2 0 0 6}$ & $\mathbf{2 0 0 7}$ \\
\hline $\begin{array}{l}\text { Total } \\
\text { exportaciones }\end{array}$ & $\mathbf{2 6 . 4 3 0 , 9 0}$ & $\mathbf{2 9 . 9 3 8 , 8 0}$ & $\mathbf{3 4 . 5 5 0 , 2 0}$ & $\mathbf{4 0 . 0 1 3 , 0 0}$ & $\mathbf{4 6 . 4 5 6 , 4 0}$ & $\mathbf{5 5 . 7 8 0 , 0 0}$ \\
\hline $\begin{array}{l}\text { Complejos } \\
\text { Oleaginosos }\end{array}$ & $\mathbf{4 . 7 3 0 , 8 0}$ & $\mathbf{8 . 0 3 1 , 5 0}$ & $\mathbf{8 . 4 5 9 , 8 0}$ & $\mathbf{9 . 3 1 7 , 8 0}$ & $\mathbf{9 . 9 5 3 , 1 0}$ & $\mathbf{1 4 . 3 3 9 , 0 0}$ \\
\hline Complejo soja & $3.232,70$ & $7.194,50$ & $7.678,50$ & $8.317,50$ & $8.926,20$ & $13.602,00$ \\
\hline $\begin{array}{l}\text { Complejo } \\
\text { girasol }\end{array}$ & $1.214,00$ & 712,60 & 663,20 & 840,80 & 810,70 & 764,00 \\
\hline $\begin{array}{l}\text { Otros } \\
\text { complejos } \\
\text { oleaginosos }\end{array}$ & 284,00 & 124,40 & 118,10 & 159,50 & 216,20 & 32,00 \\
\hline
\end{tabular}

Fuente INDEC. Elaboración: Barsky, O. y Dávila M. (2008: Pág. 68).

Cuadro N$^{0}$ 3. Evolución de los principales complejos económicos en Argentina en millones de dólares.

\begin{tabular}{|l|c|r|r|r|r|r|}
\hline & $\mathbf{2 0 0 8}$ & $\mathbf{2 0 0 9}$ & $\mathbf{2 0 1 0}$ & $\mathbf{2 0 1 1}$ & $\mathbf{2 0 1 2}$ & $\mathbf{2 0 1 3}$ \\
\hline $\begin{array}{l}\text { Total } \\
\text { exportaciones }\end{array}$ & $\mathbf{7 0 . 0 1 8 , 8 4}$ & $\mathbf{5 5 . 6 7 2 , 1}$ & $\mathbf{6 8 . 1 8 7 , 2 1}$ & $\mathbf{8 3 . 9 5 0 , 2 1}$ & $\mathbf{8 0 . 9 2 7 , 1}$ & $\mathbf{8 1 . 6 6 0}$ \\
\hline $\begin{array}{l}\text { Complejos } \\
\text { Oleaginosos }\end{array}$ & $\mathbf{1 8 . 3 9 4 , 2}$ & $\mathbf{1 3 . 9 6 3 , 7 3}$ & $\mathbf{1 8 . 0 7 9 , 3 5}$ & $\mathbf{2 2 . 0 1 3 , 7 8}$ & $\mathbf{1 9 . 3 2 7 , 9 5}$ & $\mathbf{2 0 . 9 8 5}$ \\
\hline $\begin{array}{l}\text { Complejo soja } \\
\text { Complejo }\end{array}$ & $\mathbf{1 6 . 6 0 8 , 6}$ & $\mathbf{1 2 . 9 8 9 , 7 3}$ & $\mathbf{1 7 . 3 1 7 , 1 5}$ & $\mathbf{2 0 . 5 6 0 , 5 5}$ & $\mathbf{1 8 . 0 6 0 , 3 8}$ & $\mathbf{2 0 . 0 3 2}$ \\
\hline $\begin{array}{l}\text { Compol } \\
\text { girasol }\end{array}$ & $\mathbf{7 . 2 4 6 , 8 6}$ & $\mathbf{5 . 9 8 1 , 5 4}$ & $\mathbf{8 . 6 1 9 , 5 1}$ & $\mathbf{1 0 . 6 2 7 , 1 5}$ & $\mathbf{1 0 . 1 6 7 , 7}$ & $\mathbf{1 1 . 6 2 8}$ \\
\hline $\begin{array}{l}\text { Complejo } \\
\text { automotriz }\end{array}$ & $\mathbf{7 . 6 6 2 , 0 4}$ & $\mathbf{3 . 9 3 1 , 1 9}$ & $\mathbf{5 . 4 1 6 , 7 6}$ & $\mathbf{9 . 4 2 5 , 5}$ & $\mathbf{1 0 . 5 4 0 , 2 3}$ & $\mathbf{9 . 4 4 2}$ \\
\hline $\begin{array}{l}\text { Complejo } \\
\text { cerealero }\end{array}$ & $\mathbf{8 . 5 1 0 , 3 3}$ & $\mathbf{6 . 7 7 2 , 1}$ & $\mathbf{7 . 2 1 3}$ & $\mathbf{7 . 3 8 7 . 9 6}$ & $\mathbf{7 . 5 6 4 , 0 3}$ & $\mathbf{6 . 4 6 2}$ \\
\hline $\begin{array}{l}\text { Complejos } \\
\text { petrolero- } \\
\text { petroquímico }\end{array}$ & & & & & \\
\hline
\end{tabular}

Fuente INDEC.

Otra de las innovaciones en el agro argentino es la utilización del silobolsa, elemento que permite una nueva forma de almacenar los granos a un bajo costo sin que el productor deba recurrir a los silos tradicionales. 
La "sojización" se caracteriza además, por la transformación en la que se produce la concentración de tierra, ya que la misma no es vendida sino arrendada. Esto libera a los pequeños y medianos productores de tener que invertir cuantiosas sumas de capital en maquinaria agrícola, insumos y semillas. Y, por otro lado, los productores ya no son personas físicas sino pooles de siembra, empresas financieras internacionales que arrendan tierras, tercerizan todos los procesos productivos y operan como intermediarios de grupos multinacionales. Unos 3000 pools manejan el $60 \%$ de la soja, mientras que el porcentaje restante es dividido entre 200.000 productores agropecuarios y pequeñas y medianas empresas.

A su vez, siete empresas multinacionales manejan el $80 \%$ de las ventas al exterior de la oleaginosa en Argentina; ellas son $\mathrm{ADM}^{25}$, Bunge, CHS Argentina, Dreyfus, Cargill, Nidera y Toepfer $^{26}$. El porcentaje restante está a cargo de cooperativas de pequeños y medianos productores como ser A.C.A. de Coninagro y A.F.A de Federación Agraria.

\section{Los costos del modelo.}

Ahora bien, el avance sojero que por un lado beneficia a la economía por el ingreso de dólares, ha provocado la expansión de la frontera agropecuaria hacia el Norte de nuestro país, en zonas donde tradicionalmente se sembraba trigo, en el caso de Santa Fe y algodón, en Santiago del Estero y Chaco. "En Argentina, la soja sustituyó una vastísima serie de productos agrícolas. Se redujeron por ende las áreas dedicadas a producciones típicamente pampeanas, tales como girasol, maíz y sorgo. Pero también afectó otras producciones como el cultivo de frutales en la zona ribereña, el maní en la provincia de Córdoba y la producción de lentejas y arvejas en la provincia de Buenos Aires", indica Rodríguez (2008: 89).

Según datos de los censos nacionales agropecuarios, la superficie destinada a la producción en nuestro país pasó de 33.105.585 hectáreas en 1988 a 38.064.983 en 2002; acrecentándose un 15\%. Se incorporaron 4.959.396 hectáreas de plantaciones, de las cuales 2.307.569 corresponden a provincias extrapampeanas, donde el incremento fue de un $50.3 \%$ a diferencia de un $9.3 \%$ de las provincias pampeanas.

\footnotetext{
${ }^{25}$ Archer Daniels Midland Company.

${ }^{26}$ Según datos del Ministerio de Agricultura de la Nación, en los años 2012 y 2013.
} 
Las mejores tierras para el cultivo de cereales y la actividad ganadera (cría, engorde y lechería) son las de la Pampa Húmeda, pero los elevados alquileres de la zona a causa de la soja han provocado que los empresarios migren hacia la Mesopotamia y el Nordeste, donde también se incrementó el precio de la renta.

Como asegura Adámoli, J. (2013) dicha expansión "no respondió a ningún proceso de planificación, las regulaciones que había rara vez fueron respetadas y las numerosas transgresiones producidas no tuvieron sanciones efectivas". El ingeniero agrónomo advierte sobre la urgente necesidad de declarar nuevas superficies de bosques y ecosistemas como áreas protegidas a fin de conservarlos.

La expansión de la frontera agrícola además de avanzar sobre los diversos cultivos que se consumen en el mercado interno y aumentar los precios de los alimentos, provoca la pérdida de biodiversidad por destrucción de ecosistemas naturales. Miles de hectáreas de bosques nativos han sido eliminados por el cultivo de exportación y existe un alto riesgo de desaparición de las yungas en la provincia de Salta y de los bosques de quebrachos en el este de Santiago del Estero y sudoeste de Chaco.

"Entre 2004 y 2012 las topadoras arrasaron 2.501.912 hectáreas, el equivalente a 124 veces la superficie de la Ciudad de Buenos Aires. Otra forma de decir lo mismo: en Argentina se arrasan 36 canchas de fútbol por hora. Los datos surgen del cruce de relevamientos oficiales y de ONG's. La causa, tan obvia como impune, el avance de la frontera agropecuaria, con cultivos transgénicos (soja y maíz) y la ganadería intensiva. El desmonte no es solo impacto ambiental, también implica conflictos por la tierra, represiones y asesinatos de campesinos e indígenas", denunció el periodista Darío Aranda en la revista MU (marzo de 2013).

De igual modo, el boom agrario es responsable de la degradación de los suelos fértiles en nuestro país. El estudio del INTA titulado, "Extracción y balance de nutrientes en los suelos agrícolas de la Argentina" (Cruzate y Casas: 2012) alerta sobre el registro de una elevada extracción de nutrientes no repuestos en igual magnitud, que provoca un deterioro progresivo en la fertilidad de los suelos poniendo en peligro la sustentabilidad de los sistemas productivos.

El trabajo detalla que en la campaña 2010/11 se extrajeron 3.93 millones de toneladas de nitrógeno, fósforo, potasio, sodio y calcio, de los cuales sólo se repusieron 1.6 millones de toneladas. Lo que representa un $34.6 \%$ de reposición y un déficit de casi el $65 \%$. Estos datos 
demuestran que se está practicando una agricultura extractiva, casi minera y sin reposición de nutrientes.

Por otra parte, en el afán de incorporar mayor superficie de tierras para el monocultivo, cientos de campesinos e integrantes de pueblos originarios fueron obligados en los últimos años a desalojar sus campos. En las provincias de Santiago del Estero, Chaco y Formosa son innumerables las denuncias penales por usurpación de sus propias tierras, causantes de detenciones, maltratos y muertes de campesinos. Además, cientos de familias rurales se han trasladado a las ciudades formando las villas miserias.

En los últimos tres años la provincia de Santiago del Estero fue escenario de la muerte de 3 campesinos que resistían el avance del modelo agrosojero. Sandra Ely Juárez, de 33 años, madre de dos niños, murió de un paro cardíaco frente a una topadora el 13 de marzo de 2010 en el paraje campesino de San Nicolás. Cristian Ferreyra, de 23 años, padre de un niño y militante del Movimiento Campesino de Santiago del Estero (MOCASE), fue asesinado el 16 de noviembre de 2011 en el paraje San Antonio, al norte de la provincia. Y, Miguel Galván, de 40 años, también perteneciente al MOCASE, fue asesinado en el paraje Simbol el 10 de agosto de 2012.

Según un comunicado de la Unión de Asambleas Ciudadanas (2010), "la judicialización y criminalización de las asambleas, comunidades y movimientos sociales que defienden sus territorios, es una de las estrategias desplegadas desde los sectores del poder para acallar las voces de la resistencia frente al modelo productivo, extractivo, exportador y opresor que nos imponen, producto de las políticas de recolonización que asolan nuestro continente en general y a nuestro país en particular".

El incremento de la superficie sembrada con soja va aparejado del aumento de agroquímicos. En el año 2011 se aplicaron 238 millones de litros de glifosato, que implican un acrecentamiento del $119 \%$ respecto a la cantidad utilizada en $1996^{27}$. El glifosato es el principio activo del herbicida conocido comercialmente con la marca "Roundup" producido por la empresa Monsanto. Si bien este fitosanitario es promocionado por su baja toxicidad, está comprobado que genera contaminación en suelo y aguas por su excesiva utilización y por falta de rotación de la tierra. De igual modo, cada vez son más las denuncias de campesinos con problemas de salud a lo largo del país.

${ }^{27}$ En GENOK, "Producción de soya en el Cono Sur de las Américas”; 31 de julio de 2012. 
En marzo de 2015, la Agencia Internacional para la Investigación sobre el Cáncer (Iarc), dependiente de la Organización Mundial de la Salud (OMS), agregó a cinco pesticidas como cancerígenos "posibles" o "probables" para los humanos (categoría 2A de la escala del Iarc). Inmediatamente la empresa Monsanto, principal productora mundial del agroquímico, salió a cuestionar esta clasificación para el glifosato. La firma aseguró en un comunicado "no comprender cómo el panel del Iarc pudo haber establecido una clasificación que contradice las evaluaciones científicas y regulatorias”.

En la investigación denominada "Pocos ganan, muchos pierden. Soja, agroquímicos y salud" (Álvarez, Conci y otros: 2009) quedó demostrado que en el departamento Río Segundo de la provincia de Córdoba se verificó un aumento en el peso relativo y en las tasas de mortalidad por enfermedades del sistema respiratorio y el sistema endócrino, coincidente con el aumento en el empleo de productos químicos debido al incremento de la producción agroindustrial. Asimismo, se advierte que la exposición a los productos químicos produce intoxicaciones, generando dificultades respiratorias, diarrea, vómitos, problemas de fertilidad, cáncer de pulmón, malformaciones en fetos, consecuencias en el sistema hormonal, leucemia y cáncer nasal; entre otros efectos.

"En agosto del año 2010, en la Ciudad de Córdoba, convocados por la Facultad de Ciencias Médicas de la Universidad Nacional de esa localidad, se llevó a cabo el Primer Encuentro Nacional de Médicos de Pueblos Fumigados, con el fin de generar un espacio de análisis y reflexión académica y científica sobre el estado sanitario de los pueblos fumigados, y de escuchar y contener a los miembros de los equipos de salud que vienen denunciando y enfrentando este problema”, explica Damián Verzeñassi (2014: 37).

Los detractores del modelo agrosojero denuncian que la soberanía alimentaria está en peligro. Como señala INCUPO “en Argentina casi el 90\% de la tierra está dedicada al monocultivo de exportación y no a satisfacer nuestras necesidades alimentarias. Fueron desplazados la lechería, el cultivo de maíz, el trigo, la lenteja, huertas y otros alimentos de consumo interno. Estamos perdiendo la capacidad de asegurar nuestra alimentación y de decidir qué alimentos queremos consumir, qué producir y dónde vender" 28 .

\footnotetext{
${ }^{28} \mathrm{http} / / /$ redaf.org.ar/wp-content/uploads/2008/04/las-protestas-rurales.pdf
} 
En esta misma línea se posiciona Pedro Peretti, director titular de Federación Agraria Argentina (FAA); quien sostiene que, "el debate central y madre de todas las batallas de la política agropecuaria del país es quién siembra y produce los alimentos, lo hacen miles de campesinos y chacareros o algunos cientos de megaempresas. En esto no hay neutralidad posible, es responsabilidad de todos participar en el debate de cómo se sirve la mesa de los argentinos" (2013:18).

Según Peretti, el tema agropecuario sólo aparece en los suplementos especializados de los grandes diarios, y pregunta además, cuándo aparecerá en los medios lo que le cuesta al país, este proceso de monocultivo, inducido con concentración, vía migraciones rurales, cinturones de pobreza y salud. "La pobreza rural nunca aparece, nunca dicen los miles de puestos de trabajo que destruyeron, las miles y miles de chacras desaparecidas, los millones de compatriotas que se vieron obligados a migrar", señala Peretti. 


\title{
II. SEGUNDA PARTE
}

\section{II.1. La rentabilidad del modelo agrosojero.}

\author{
"Bajo el falso pretexto de una crisis económica sin precedentes, \\ está por consumarse la gran estafa a los intereses y a las aspiraciones \\ de la nacionalidad. Quienes en este momento ejercen el poder y \\ tienen fuerza para convertir en ley sus decisiones, deben asumir \\ la tremenda responsabilidad de la política económica (...) \\ En la reforma económica está el secreto de nuestro porvenir libre o esclavo, \\ del bienestar o de las penurias de los argentinos...".
}

Arturo Jauretche (2010: 30)

UA 1. La noticia seleccionada se ubica en el suplemento Campo del 9 de febrero de 2013; segmento especial destinado al sector agropecuario que acompaña al diario La Nación todos los sábados. Puede señalarse además, que ocupa alrededor del $48 \%$ de la página 7 , lo que denota la importancia que se le otorga al tema.

El diario titula de manera informal, utilizando expresiones propias de la jerga económica y emplea el recurso de la comparación para cotejar el valor de dos productos de diferentes rubros en un periodo determinado: "El ladrillo le gana al poder de compra de la soja 2012/13".

Por otra parte, en la bajada señala de manera latente que en la actualidad los productores no obtienen ganancias elevadas de la cosecha y conlleva a relacionar el panorama actual con la crisis económica del año 2001: "La oleaginosa tiene el mismo poder adquisitivo de bienes de construcción que en los momentos más críticos de la economía".

A lo largo del discurso se emplea la comparación para explicar cómo en la campaña 2012/2013 se deterioró el poder de compra que tenía la soja respecto al ladrillo, en diferentes años:

- "Una estimación propia indica que el poder de compra interno de un camión de soja puede quedar en 12,4 metros cuadrados en este 2013, un 11\% por debajo del nivel de 2012 y un $29 \%$ por debajo del promedio de los últimos 21 años".

- "En 2002 un camión de soja de 28 toneladas valuado a los precios internos podía financiar casi 30 metros cuadrados de construcción (...)".

- "En setiembre de 2005 el nivel de actividad de la construcción (según mediciones del Indec) ya superaba los máximos de la década de los 90". 
- "En 2012 un camión de soja pudo comprar 13,8 metros cuadrados de construcción. Para tener una perspectiva histórica, este valor está un 25\% por debajo del nivel promedio del período posconvertibilidad (18,4 metros cuadrados por camión) y, lo que sorprende, un $15 \%$ por debajo del nivel del período de la convertibilidad (16,3 metros cuadrados por camión). Adicionalmente, hay que retroceder hasta 2001 para encontrar un valor menor (12,8 metros cuadrados)".

También emplea la figura retórica de la metáfora para señalar que la oleaginosa tiene el mismo "poder de marcar" o "poder adquisitivo" relacionados en términos de construcción que en el año 2001: "La soja tiene hoy casi el mismo poder de fuego en términos de bienes construcción que en los momentos más críticos de la economía argentina”.

En lo referente a los subjetivemas, en el discurso se utilizan evaluativos no axiológicos para explicar las causas del poder de compra de la soja: "Elevados impuestos $(35 \%$ derechos de exportación)" y "Una inflación doméstica en bienes construcción excepcionalmente alta (promedia el 25\% anual entre 2009 y 2012)". Y, se emplea también el evaluativo axiológico “desfavorables" para establecer un juicio de valor negativo sobre los "términos de intercambio" de la soja.

El diario responsabiliza de manera implícita al Gobierno Nacional de la desfavorable situación económica que atraviesan los productores, aunque sin mencionarlo: "Se mantienen sin cambios los derechos de exportación y la política comercial que se aplica sobre la soja”.

Por otra parte, omite explicar que la devaluación sufrida por el peso argentino respecto al 2001 benefició al sector agroexportador, teniendo en cuenta que la producción cotiza en dólares. Esto se conjuga con la estrategia global del discurso que señala, de manera latente, que el productor se encuentra perjudicado en medio de un panorama económico desfavorable. Según van Dijk (1997: 38 y 39), si se informa de una noticia de forma "sesgada", es porque normalmente el modelo mental del periodista contiene características y opiniones que favorecen una perspectiva ideológica específica sobre el suceso.

Para finalizar, se utiliza una fotografía que según su uso se clasifica como documental, en la cual se observan tres máquinas cosechadoras y una contenedora realizando la zafra en un predio de soja. Y, a través de un gráfico se expone cuántos metros de construcción se pudieron financiar con un camión de soja de 28 toneladas; desde el 2001 a 2012. Como fuente figuran el Ministerio 
de Agricultura, Ganadería y Pesca de la Nación (MAGyP), Bolsas de Cerealeras y el propio diario La Nación. Dicho gráfico es editorial debido a que el periódico selecciona información desfavorable para el sector en términos económicos. Recordemos además, que para van Dijk, los gráficos son elementos fundamentales en la expresión de la ideología y una forma de otorgarle valor noticioso al acontecimiento.

UA 2. En el título, "La siguen cosechando con pala", Página 12 utiliza expresiones propias de la comunicación oral cotidiana a fin de crear complicidad con el lector en relación al enunciado sobreentendido. Quien lee el titular, lo relaciona con la frase conocida "la siguen juntando con pala", que indica abundancia o ganancia. Esta estrategia de fondo es a lo que Prieto Castillo (1999: 120) llama "sentido de oportunidad", recurso que juega un papel fundamental en el uso lúdico del lenguaje y que sirve para llamar la atención del lector.

La noticia se encuentra ubicada en el rubro Economía en la edición del 19 de febrero de 2013 y ocupa el 75\% de la página número 8. Debajo y a la derecha figura otra noticia sobre la oleaginosa titulada, "Con el viento a favor", que ocupa el 15\% de la página. El espacio que el matutino le brinda a los discursos sobre la soja y la ubicación en una de las secciones más importantes es una primera manera de jerarquizar el hecho.

Tanto en la volanta como en la bajada se desmiente el relato de los empresarios del agro sobre una "supuesta crisis" y señalan que éste discurso no se condice con los precios de la tierra, la carne y la soja:

- "Las quejas ruralistas no se corresponden con la situación del agro", señala la volanta.

- "La evolución que registraron en los últimos años los precios de la tierra y dos productos clave como la carne y la soja desmienten el relato empresario sobre una supuesta crisis del sector agropecuario", explica la bajada.

El discurso utiliza indicadores como el precio de la tierra, la carne y la soja para dar cuenta de la rentabilidad del sector y refutar el argumento de la Mesa de Enlace cuando "afirma que el campo atraviesa un momento difícil debido a la política agropecuaria nacional" y amenaza con medidas de fuerza. Asimismo, predica que: "Los presidentes de las entidades rurales buscan ampliar aún más sus ganancias...” y por otra parte, refuta los pronósticos catastróficos y 
desalentadores de analistas y ruralistas con respecto al clima y a los precios internacionales de la soja:

"Luego de haber alcanzado un pico de 533 dólares a fines de agosto de ese año (2011), el precio de la oleaginosa empezó a retroceder y fueron varios los analistas que pronosticaron un futuro sombrío para el país. Los ruralistas decían que la baja del precio, combinada con una sequía que entonces preveían como apocalíptica, dejaría al campo en una situación crítica. Sin embargo, nada de eso ocurrió. Las lluvias trajeron alivio a los productores y la cotización de la soja se recuperó. En la actualidad, cotiza a 520 dólares en el mercado estadounidense”.

Para contradecir el argumento de los empresarios y exponer la bonanza del sector utiliza datos de la Cámara de la Industria y Comercio de Carnes y Derivados, los mercados de Liniers y Chicago, que operan como fuentes textuales institucionales oficiales, según la clasificación de Lucrecia Escudero. Las mismas dan un efecto de veracidad y de alguna manera vienen a probar el argumento del enunciador.

En el discurso se emplea la comparación para demostrar el acrecentamiento de la rentabilidad del sector agrario con el paso del tiempo. Para ello, se coteja el valor de la tierra en febrero de 2013, 6 meses antes a febrero de 2013, en los últimos 10 años y en junio de 2002 en distintas áreas geográficas: 1) La zona maicera de Pergamino, Rojas y Salto. 2) Los campos trigueros de Tres Arroyos, San Cayetano y Necochea. 3) Los campos mixtos de Bragado, 9 de Julio, Viamonte y Lincoln. 4) Los dedicados a la cría de ganado, Tapalqué, Rawch, Maipú y Dolores. 5) Y, de invernada de Trenque Lauquen, Villegas y Rivadavia.

Por citar algunos ejemplos:

1) "En la zona tradicionalmente maicera de Pergamino, Rojas y Salto, la hectárea se vende actualmente a 16.500 dólares en promedio, un 5,7 por ciento menos que el pico registrado hace seis meses, pero un 132,7 por ciento más que el promedio de los últimos diez años (7089 dólares) y un 560 por ciento más que el piso registrado en junio de 2002 (2500 dólares)".

2) "En los campos trigueros de Tres Arroyos, San Cayetano y Necochea la hectárea cotiza a 6500 dólares, un 13,4 por ciento menos que hace seis meses, pero un 128 por ciento más que el promedio de los últimos diez años (2848 dólares) y un 712,5 por ciento más que en junio de 2002 (800 dólares)". 
Compara además el aumento registrado en el precio de novillos, novillitos, vaquillonas y terneros: “...si se toma en consideración la evolución desde febrero de 2009 se puede ver que en cuatro años el kilo vivo de novillo trepó de 3,04 a 9,72 pesos (219,5 por ciento), el de novillito de 3,24 a 10,62 pesos $(227,7)$, el de vaquillona de 3,16 a 10,17 pesos $(221,9)$ y el de ternero de 3,37 a 10,99 pesos (226,2 por ciento), todos muy por encima de la inflación acumulada en el período”. Y, para finalizar, compara el precio de la soja en el Mercado de Chicago, Estados Unidos, en los períodos de agosto y diciembre 2011 y febrero 2013:

- “Cuando Cristina Fernández de Kirchner asumió su segundo mandato, el 10 de diciembre de 2011, la tonelada de soja cotizaba a 408 dólares en Chicago. Luego de haber alcanzado un pico de 533 dólares a fines de agosto de ese año, el precio de la oleaginosa empezó a retroceder y fueron varios los analistas que pronosticaron un futuro sombrío para el país. Los ruralistas decían que la baja del precio, combinada con una sequía que entonces preveían como apocalíptica, dejaría al campo en una situación crítica. Sin embargo, nada de eso ocurrió. Las lluvias trajeron alivio a los productores y la cotización de la soja se recuperó. En la actualidad, cotiza a 520 dólares en el mercado estadounidense”.

Según este medio, la Mesa de Enlace argumenta una crisis que en realidad no existe y devela que el sector agropecuario amenaza con medidas de fuerza porque busca ampliar aún más sus ganancias.

En cuanto a las palabras escogidas para mencionar al sector, el diario utiliza las siguientes: "Mesa de Enlace", "empresarios", "ruralistas", “entidades rurales" y "productores".

De igual modo, el sector agropecuario aparece asociado con las siguientes palabras que aluden al buen momento económico que atraviesa: "rentabilidad", “evolución de los precios", "ganancias", "negocio muy rentable", "aumento", “fuerte suba", "bonanza" e “inversión”.

Según la clasificación que realiza Thibault Laulan, la fotografía es documental, ya que la imagen se adhiere a la realidad o intenta reproducirla en sus conexiones esenciales. La misma, muestra una extensa plantación de soja y en su epígrafe señala: "Los presidentes de las entidades rurales buscan ampliar aún más sus ganancias”.

Por su parte, la subnota titulada "Con el viento a favor", que acompaña a la noticia principal, utiliza expresiones propias del lenguaje popular para significar que se avizora un panorama 
favorable. Eliseo Verón llama "efecto de reconocimiento" a la estrategia por la cual un medio titula en complicidad con el lector, al emplear expresiones existentes en su campo cultural.

El título, que no explicita el tema, se apoya en la volanta para explicar que las "proyecciones para la soja" son favorables.

En el primer párrafo se confirma y amplía lo que resaltan los elementos de lectura rápida: "Las proyecciones para la campaña agrícola 2012/2013 mantienen por encima de los 50 millones de toneladas la cosecha de soja”.

Se utiliza como fuente un informe de la Bolsa de Cereales de Buenos Aires que describe un panorama optimista para el agro, contraponiéndose a los pronósticos catastróficos de sequía anunciados por los ruralistas:

- “... las lluvias que cayeron durante el fin de semana en extensas áreas productivas, fundamentalmente el norte y centro de nuestro país, mejoraron las proyecciones para la oleaginosa".

- "Se percibe una lenta pero efectiva mejora de la oferta hídrica de los lotes".

- "Mientras que las entidades patronales agropecuarias amenazan con realizar un lockout sojero, las lluvias mejoraron sus perspectivas de rendimiento".

UA 3. La noticia "Un doble impacto sobre el campo" fue publicada en el rubro Economía del diario La Nación, en su edición del 21 de marzo de 2013. Se sitúa en el extremo inferior de la página 15, debajo de la nota titulada "Imparable, el dólar paralelo aceleró su escalada en una jornada cargada de rumores" y ocupa alrededor del 15\% de su espacio.

En la bajada se resalta que ante la suba del dólar paralelo, los productores podrían suspender sus ventas por la incertidumbre y se teme un alza en los insumos del sector agropecuario; variables especulativas que se desarrollarán a lo largo del discurso: "Los productores podrían retener sus ventas por la incertidumbre; temor a una suba en los insumos".

En la noticia se establecen conjeturas poco alentadoras sobre los efectos que sufriría el sector agropecuario, en general y sojero, en particular, a partir de la escalada del dólar paralelo:

- "Por un lado, llevaría a los productores a retener sus ventas de granos a la espera de una suba mayor del billete oficial". 
- "Por otra parte, los insumos del sector entrarían en zona de aumentos, ya que, si bien se importan al dólar oficial, a las empresas proveedoras se les podría hacer más cara y complicada la reposición de productos".

Para avalar estas predicciones, utiliza la palabra de consultoras privadas y de la Sociedad Rural, a través de citas directas:

- “Los productores evitarán vender granos a menos que sea necesario. Todos prefieren tener granos que pesos. Es más, no sería raro que cuando se liquide la cosecha nueva se vuelquen al dólar, incluso pagándolo a precio blue, lo cual hará que siga subiendo aun más', expresó Guillermo Villagra, consultor de Openagro".

- “Le saca incentivos a vender más [al productor] ', subrayó Gustavo López, consultor de Agritrend, sobre la disparada del 'paralelo'”.

- "Ernesto Ambrosetti, economista jefe de la Sociedad Rural Argentina (SRA), cree que el productor prevé una devaluación más importante del peso. 'Piensa que se va a devaluar un poco más rápido de lo que lo venía haciendo', señaló".

En estos ejemplos, la palabra ajena es utilizada como cita autoridad ya que los enunciados se producen en función de la persona que habla.

Por otra parte, para probar que el desfasaje entre el dólar oficial y el blue también afectarán al productor a la hora de comprar insumos, se utiliza la voz de un empresario rural que respalda las opiniones del enunciador y otorga un efecto de veracidad al discurso:

- “La preocupación del productor es que aumenten los insumos estratégicos para la incorporación de tecnología', indicó. 'En realidad, los insumos ya están haciendo el seguimiento del blue', advirtió el productor Néstor Roulet".

- "La brecha en el dólar produce distorsiones. Y sobran los ejemplos. Según Roulet, si con la venta de soja a unos 1650 pesos la tonelada el productor fuera a comprar dólares en el mercado blue, recibiría 193 dólares. Esto es, un 41\% menos que los 324 dólares que obtendría si consiguiera los dólares en el mercado formal".

Como puede observarse, la palabra ajena refuerza la idea de un pronóstico económico desfavorable para el sector agroexportador y construye la idea de un sector que es víctima de "un gobierno ávido de dólares", como lo señala de manera textual. 
A modo de resumen, en este discurso el productor se encuentra asociado a las siguientes descripciones: "espera una suba mayor del billete oficial", "prefieren retener granos que pesos", “prevén una devaluación del peso” y le preocupa que aumenten los insumos.

UA 4. La noticia titulada "Serán récord las cosechas argentinas de soja y maíz" se ubica en la página 14 del rubro Economía en la edición del 22 de marzo de 2013 del diario La Nación, ocupando un $10 \%$ de su espacio. La nota, encarada en términos productivos, toma como fuente al Ministerio de Agricultura, Ganadería y Pesca de la Nación (MAGyP) que informa acerca de su primera estimación sobre las cosechas 2012/2013 de soja y maíz, vaticinando resultados máximos en la producción sojera y maicera.

El diario reproduce la palabra del organismo nacional en calidad de "voz autorizada", a través de una cita directa: "en caso de no producirse situaciones adversas (falta de lluvias o heladas tempranas), las primeras evaluaciones permiten estimar una producción de soja de 51.30 millones de toneladas".

A través de la estrategia de la comparación coteja la cifra de la cartera agropecuaria con los otorgados por instituciones privadas del ámbito nacional y por el Departamento de Agricultura de los Estados Unidos (USDA): "El dato brindado por el Minagri en su estimación mensual de marzo quedó levemente por debajo de los 51,50 millones de toneladas calculados por el USDA, pero bastante por encima de los 48,50 millones proyectados por la Bolsa de Cereales de Buenos Aires (BCBA) y de los 48 millones previstos por la Bolsa de Comercio de Rosario (BCR)”.

En el extremo inferior izquierdo de la página aparece otra noticia sobre el tema que nos ocupa; titulada, "La soja se cotizó con fuertes mejoras y volvieron las ventas". La misma detalla el precio que se pagó por el producto en diferentes mercados, tanto internos como del exterior. Como puede observarse, el diario La Nación hace alusión al valor de la oleaginosa para informar a sus lectores que presumiblemente formen parte de la cadena de producción sojera o se encuentren interesados en el tema.

La noticia utiliza las siguientes fuentes textuales institucionales oficiales, buscando un efecto de veracidad: Bolsa de Comercio de Rosario (BCR), Mercado a Término de Buenos Aires (Matba) y bolsas de Cereales de Buenos Aires (BCBA) y de Chicago. 
Para explicar el comportamiento del mercado externo y su impacto en el argentino, utiliza el reporte diario de la BCR que señala, "por las importantes subas registradas en la Bolsa de Chicago y ante la necesidad de algunos compradores locales, los precios de la soja argentina repuntaron ayer en el mercado disponible local e incentivaron la venta de unas 30.000 toneladas". Seguidamente, se realiza un balance sobre lo que se pagó por la soja en diferentes mercados:

- "La soja con entrega entre abril y mayo se negoció a 325 dólares por tonelada en San Lorenzo, San Martín y en Timbúes, con una mejora de 10 dólares. 'Por la mañana circuló el rumor de que una fábrica concertó negocios a 327 dólares por tonelada', dijo la BCR”.

- "En Bahía Blanca y en Necochea las subas fueron de 3 y de 5 dólares, dado que los exportadores propusieron 326 y 320 dólares por tonelada, respectivamente".

- "Los contratos mayo y julio de la soja en el Mercado a Término de Buenos Aires (Matba) aumentaron ayer US\$ 4,90 y 5,50, mientras que sus ajustes fueron de 328,90 y de 332,20 dólares por tonelada".

- "El origen de la tónica alcista estuvo -como suele suceder- en la Bolsa de Chicago. Allí, las pizarras mostraron subas de US\$ 10,75 y de 9,65 sobre las posiciones mayo y julio de la soja, cuyos ajustes resultaron de 532,42 y de 523,79 dólares por tonelada”.

De igual modo, utiliza como fuente a la agencia de noticias internacional Reuters para explicar la situación de mercados internaciones debido a que la demanda externa podría requerir la producción sojera de Argentina: "China está vendiendo entre 1 y 1,5 millones de toneladas de soja de sus reservas estatales a los molinos para aliviar una ajustada oferta tras los problemas de logística en los puertos de Brasil, dijeron ayer operadores chinos. La soja ofrecida por Sinograin, la compañía que administra las reservas estatales, formaba parte del stock de porotos importados, que deberá ser repuesto en el futuro con embarques de América del Sur o de EE.UU., dijeron los operadores".

Como puede observarse, la cotización de la soja en diferentes mercados está asociada a términos que describen un panorama favorable para los productores: "importantes subas", repunte de los precios, aumentos, "mejora de 10 dólares", "subas" y "tónica alcista".

Las dos noticias aquí analizadas predicen un excelente panorama para la producción y cosecha de la soja en la campaña 2012/2013, que según el MAGyP alcanzaría un récord de de 51.30\% millones de toneladas y por otra parte, destacan la importante suba del precio de la oleaginosa en 
mercados y bolsas nacionales e internacionales. Dichas noticias, sin dudas contrastan con UA 3, publicada por el mismo diario en la edición del día anterior, en la que se pronostica un escenario desfavorable para los productores, que podrían retener sus ventas de granos a la espera de una suba mayor del billete oficial y que se ven afectados por los dos tipos de cambio del dólar (oficial y el blue) a la hora de comprar insumos. Estos dos escenarios tan disímiles planteados por el diario La Nación, hacen suponer que la situación caótica del sector agrario, descrita en la UA 3, no es tal y que el productor se verá beneficiado con los aumentos del precio de la soja en dólares, como lo detalla la UA 4.

UA 5. "Nuevas variedades de soja e híbridos de maíz presentó Syngenta en Santa Isabel”, titula el diario La Nación en la tapa del suplemento Campo, el 30 de marzo de 2013. En el interior del mencionado suplemento, la noticia ocupa alrededor del $45 \%$ de la página 5 . La cantidad de espacio utilizado y el hecho de haberla anunciado en la portada indican que se trata de un acontecimiento jerarquizado.

El título "Granos gruesos con mayores rindes" utilizado en la página 5 no resulta del todo informativo por lo que necesita de otros elementos de lectura rápida para adelantar de qué tratará. Es así que en la bajada destaca el nombre de la compañía biotecnológica que organizó una jornada en una localidad santafesina para promocionar nuevas variedades de soja y maíz: "Expo Syngenta. En la muestra, realizada en Santa Isabel, provincia de Santa Fe, se vio la nueva tecnología que permitirá mejores estándares para la producción de soja y maíz; la visitaron más de 600 productores y técnicos".

El discurso resalta información positiva sobre la nueva tecnología propuesta por la compañía Syngenta y alega que la utilización de este paquete permitirá que los productores adquieran granos gruesos de soja y de maíz, y mayores rindes, tal como lo resalta el primer párrafo de la noticia: "Toda la tecnología que permitirá explorar nuevos potenciales en la búsqueda de mejores estándares de rendimiento para granos gruesos se vio en la nueva edición de Expo Syngenta, realizada en Santa Isabel, provincia de Santa Fe, a la que asistieron más de 600 productores y técnicos". 
El discurso señala de manera explícita que los productos de Syngenta permitirán mayores rindes y de manera implícita que al utilizar la tecnología propuesta por dicha compañía, los productores podrán obtener mayores ganancias económicas al momento de vender la cosecha.

En la noticia se intenta persuadir a los lectores dedicados al agro para que adquieran las variedades de semillas que comercializa Syngenta y para ello, se mencionan los atributos positivos del producto: "Entre las nuevas variedades comerciales de soja se destacaron dos de alto rendimiento: una, de madurez III medio, que garantiza baja susceptibilidad al vuelco, es resistente al cancro del tallo y a MOR, y la otra, de un grupo III largo, de muy baja susceptibilidad al vuelco, resistente al cancro del tallo, ideal para el norte de Santa Fe".

De igual manera, se pretende instruir al productor de soja y maíz sobre los adelantos en materia de tecnología. En este sentido, reproduce la palabra autorizada -a través de citas directas e indirectas- de los expertos del grupo CREA y de la Universidad del Litoral que disertaron en el evento:

- "En una de las estaciones, Diego Pérez, del CREA Rosario, se refirió al manejo de las densidades de siembra y su impacto en los rindes. (...) Presentó más de 60 ensayos realizados en dos campañas con densidades de 9 a 33 plantas por metro cuadrado, y concluyó que el mayor rinde se obtuvo entre 16 a 20 plantas por metro cuadrado en grupos 4 largo sembradas en noviembre”.

- "Precisamente, la tecnología Plenus, por su alto poder germinativo, ’permite bajar la densidad de siembra, generando un importante ahorro de semillas', explicaron los técnicos. Viene en tres formatos: con protección contra enfermedades; con tres fungicidas y un insecticida, y para quienes tengan problemas de nematodos, todos con formulaciones en inoculantes desarrollados con Rizobacter”.

- "La estación enfermedades en soja estuvo a cargo de Margarita Sillon, de la Universidad del Litoral, quien propuso cambiar el concepto de control por el de manejo. `Se debe pensar en dos frentes de protección: uno a la siembra y otro foliar. Arrancar con un buen tratamiento de semillas y combatir enfermedades foliares es una doble estrategia que potencia los resultados. En este caso la combinación de Plenus y Amistar Xtra incrementó los rindes', dijo". 
Al igual que en la UA 7, en esta noticia también se promocionan las nuevas variedades de semillas de Syngenta, compañía que destina grandes sumas de dinero a las publicidades de página completa en el suplemento Campo de La Nación. Otro dato, no menos importante, es que el mencionado diario forma parte de la organización de las ferias Expoagro y La Nación Ganadera, donde se realizan negocios vinculados a maquinarias, productos transgénicos y agroquímicos y donde también participa Syngenta. Esto puede explicar porqué el diario le otorga espacio a los eventos organizados por la compañía y la menciona en sus noticias.

Teniendo en cuenta el cuadrado ideológico planteado por van Dijk, en la noticia enfatiza información positiva sobre el nuevo producto de la marca Syngenta, como puede observarse en las siguientes predicaciones: "potencia los resultados", "incrementó los rindes", "permitirá explorar nuevos potenciales", "mejores estándares de rendimientos", "alto rendimiento", "alto poder germinativo" y "ahorro de semillas".

El texto está acompañado de una fotografía que documenta la presencia de un gran número de personas en la muestra realizada en Santa Isabel, provincia de Santa Fe.

UA 6. La noticia titulada "Advierten que se deteriora el poder de compra de la soja por la suba de los costos y la inflación" se encuentra ubicada en la página 20 del rubro Economía del diario La Nación, en su edición del 19 de abril de 2013. Si bien, no se trata de una noticia que sea mencionada en la tapa, ocupa el 50\% de la página en su parte superior y está acompañada de una fotografía del cultivo, lo que demuestra la jerarquización del acontecimiento.

Este periódico, fiel a su público -conformado entre otros sectores por productores sojerosaborda el tema de la soja desde una perspectiva financiera y lo analiza en términos de rentabilidad, dejando de lado aspectos sociales.

La noticia predica que el sector rural se encuentra "afectado por la inflación" y victimiza al productor sojero enfatizando en la pérdida de su poder adquisitivo, como ocurre también en la UA 3, titulada "Un doble impacto sobre el campo" (La Nación 21/03/2013). Para probar lo que señala, el enunciador recurre a un informe de Ieral Fundación Mediterránea, que manifiesta: “el poder de compra de la soja caería este año, si se lo compara con 2012, un 12\% en términos de bienes de la construcción y un $11,8 \%$ respecto de bienes de consumo". 
Además, se otorga la palabra, a través de citas directas e indirectas, al economista Juan Manuel Garzón de Ieral Córdoba, que en su calidad de voz autorizada refuerza la idea de un deterioro económico: "mientras en el período 2002/05 con un camión cargado de soja (28 toneladas) se podían comprar 24 metros cuadrados de una propiedad, este año los productores pueden adquirir 11,8 metros cuadrados".

Otra fuente utilizada es un estudio de la consultora Empiria que opera como "cita autoridad", ya que los enunciados se producen en función de la institución que habla: "un estudio de la consultora Empiria afirma que el ahorro en soja será casi inevitable por una conjunción de estos factores: 'Expectativas devaluatorias, cepo cambiario y la tasa de interés real negativa en pesos'”. Cabe señalar que a través de esta declaración el diario La Nación reconoce que la cosecha de soja es retenida debido a "expectativas devaluatorias".

En cuanto al cuadrado ideológico propuesto por van Dijk, la noticia enfatiza en que el productor se encuentra afectado económicamente. En este sentido argumenta que, "el costo de la canasta de bienes de consumo aumentó un 25\% y el costo de la construcción un 26\%", lo que desaceleró la edificación en las grandes ciudades. Por otra parte, suprime información sobre la ganancia que genera la producción de soja, teniendo en cuenta la cotización de la oleaginosa en el mercado internacional y su valor en dólares. Esto tiene que ver con lo que Prieto Castillo denomina "lo dicho y lo no dicho" (1999:81), una estrategia de fondo del discurso que requiere información del contexto y antecedentes que permitan leer lo que se nos está negando u ocultando con alguna intención.

Y finalmente el discurso, enfatiza que el Estado Nacional se beneficia con la producción de soja, señalando que, “en concepto de derechos de exportación, recaudaría entre 9050 millones y 9600 millones de dólares en 2013, lo que supone entre 700 millones y 1200 millones más que el año pasado".

UA 7. Con el título "Mejor imposible: la soja de 60 quintales", la tapa del suplemento Campo del diario La Nación resalta la situación favorable de la oleaginosa en torno a los altos rindes en lotes del centro sur de Santa Fe y el sudeste cordobés. Una extensa fotografía, que junto a los elementos de titulación ocupan el $50 \%$ de la página, adelanta que se trata de la noticia más importante del suplemento que acompaña la edición del 27 de abril de 2013. En la imagen 
aparece Roberto Levingston, un productor de la zona El Trébol, Santa Fe, rodeado de una plantación de la oleaginosa y en el fondo se vislumbra desenfocada una cosechadora. En cuanto a la clasificación que realiza Verón sobre las fotografías, se trata de una "foto pose" en la que el personaje ofrece su imagen al fotógrafo y por otra parte, es documental porque demuestra un lote que otorgó altos rindes.

En el interior del suplemento, el tema aparece desarrollado en las páginas 4, 6 y 7. En la cuarta, con un análisis económico titulado, "Transición bajista de la soja en Chicago". En la sexta, con la noticia principal titulada, "La soja inalcanzable se hace realidad: 60 quintales". Y, finalmente, en la séptima con dos notas tituladas, "Mal en el NOA y dispar en otras regiones" y "Preocupación por las empresas". Cabe señalar que en las páginas 6 y 7 aparece el seudorrubro "La campaña agrícola", como una manera de clasificar y jerarquizar el hecho.

La noticia titulada, "La soja inalcanzable se hace realidad: 60 quintales", está encarada en términos de productividad y rendimiento del cultivo oleaginoso, y posee fines instructivos/educativos para los lectores que puedan dedicarse a la producción de la soja. En este sentido, señala que los resultados fueron posibles debido a la conjunción de condiciones climáticas, paquetes tecnológicos, manejo y genética. Además, se explica que a mayores rindes, mayores ganancias para los productores.

En la noticia se predica que la productividad fue posible también debido al uso de las siguientes semillas genéticamente modificadas: "Don Mario, Nidera y Syngenta"; compañías que publicitan con frecuencia en el suplemento rural del centenario diario ${ }^{29}$ y que auspician las distintas feriasremates de La Nación Ganadera ${ }^{30}$, emprendimiento organizado por el periódico homónimo. Por lo que la noticia que nos ocupa podría ser clasificada como una "publinota"; nombre utilizado en la jerga periodística para señalar que la información contiene publicidad encubierta, que en este caso beneficia a empresas "socias" de La Nación.

En cuanto al cuadrado ideológico, el diario expresa información positiva sobre las semillas genéticamente modificadas otorgándole la palabra a Rodolfo Rossi, especialista en soja de la

\footnotetext{
${ }^{29}$ Por ejemplo, en la página 7 del suplemento Campo de la edición del sábado 9 de febrero de 2013 aparece una extensa publicidad de Syngenta que dice: "Con Amistar Xtra, las enfermedades quedan bien lejos de su soja. Hojas verdes por más tiempo. Mayores rindes. Más energía que se convierte en más kilos por hectárea".

${ }^{30}$ Entre ellas, La Nación Ganadera Olavarría, llevada a cabo anualmente en la provincia de Buenos Aires y La Nación Ganadera Norte, en Resistencia, provincia de Chaco.
} 
firma Nidera, quien asegura que, "la genética está dando cada vez más sorpresas, como la de los altos rindes que ahora se conocen. Hay regiones del norte de Buenos Aires y el sur de Santa Fe que tuvieron un comienzo muy favorable por el almacenaje de agua. Esto para los grupos III largos y IV, que se siembran en los mejores lotes, aseguraron un piso alto de rinde. Además, en lotes promedio el grupo V corto también empujó y contribuyó a levantar el piso con varios lotes con rindes altos. Ambos ejemplos tienen que ver con la genética, cada vez mejor en las nuevas variedades".

Por otra parte, enfatiza información negativa sobre el Gobierno Nacional: "Un productor de la misma zona de Livingston, que prefirió no identificarse por miedo a que el Gobierno tome los altos rindes como un indicador equívoco sobre el sector, se confesó: 'Mi promedio en soja va a estar en algo más de 50 quintales. En algunos lotes la máquina llegó a medir más de 60 quintales, algo que nunca había visto y que parecía imposible de lograr'".

En la noticia se otorga la palabra con fines educativos, al ingeniero agrónomo, Mauricio Kunicic y al productor Roberto Livingston; quienes comentan sus experiencias sobre los rendimientos de la oleaginosa:

- "'Hay que hacer todo de primera para lograr la mayor productividad', dice, a modo de lema, Kunicic. En rigor, esos lotes de súper rindes tuvieron tres aplicaciones de fungicidas, dos en estado vegetativo y otra en R 3 [estado reproductivo], fertilización con 150 kilos de superfosfato simple, control y aplicaciones de herbicidas contra chinche y aplicación foliar en R 5 de una mezcla de macro y micronutrientes para potenciar el rinde".

- "'Esto fue una combinación de ambiente, tecnología, manejo y genética', resaltó (Kunicic). Precisamente, por el lado de la genética se inclinó por sembrar DM 4612, una variedad de Don Mario de grupo cuatro medio".

- "'En mi caso no hubo variedades que aflojaran', señaló (Roberto Livingston). Entre las variedades que siembra hay materiales de Don Mario, Nidera y Syngenta".

En estas citas, el ingeniero Kunicic y el productor Livingston resaltan la productividad alcanzada en sus lotes de soja al haber utilizado las tecnologías de Don Mario, Nidera y Syngenta. 
Se utiliza además, la palabra de referentes de la Bolsa de Cereales de Buenos Aires y de la firma Nidera, que según la clasificación de Lucrecia Escudero pertenecen a las denominadas fuentes textuales institucionales oficiales:

- "En la Bolsa de Cereales de Buenos Aires también tienen registros de lugares con súper rendimientos. Maximiliano Zavala, analista de la entidad, los detalló: 'En Tortugas, 60qq/ha; en Cañada de Gómez, 50qq/ha; en Venado Tuerto, 50qq/ha; Peyrano también 50qq/ha; en Chovet 50qq/ha y en San Jorge, 60qq/ha'. Zavala aclaró: 'Obviamente, son lotes puntuales'",

- "Rodolfo Rossi, especialista en soja de la firma Nidera, cree que la genética está dando cada vez más sorpresas como las de los altos rindes que ahora se conocen”. Como puede observarse, en esta cita indirecta aparece una descripción positiva para los adelantos en materia genética.

En cuanto a los subjetivemas, se utilizan evaluativos no axiológicos para valorar cualitativa y cuantitativamente la productividad de la soja: "La soja inalcanzable se hace realidad: 60 quintales", "Hubo súper rindes en lotes enteros en el centro sur de Santa Fe y el sudeste de Córdoba", "Un récord que cruzó la barrera de lo imposible".

Se emplean además, evaluativos axiológicos para valorar positivamente los rindes de la cosecha: "Es la sorpresa positiva de la campaña...", "La buena nueva se vio en ciertos lugares de la zona núcleo, como en el centro sur de Santa Fe".

En este discurso se vuelve a observar un gran contraste con las UA 3 y UA 6, en las cuales el diario La Nación describe un panorama económico desfavorable para los productores y los victimiza.

UA 8. La noticia titulada "El precio de la soja subió por tercera rueda consecutiva", se ubica en el rubro Economía del diario La Nación, en su edición del viernes 15 de mayo de 2013. El discurso se sitúa en el extremo inferior izquierdo de la página 15, rodeada de cuadros que informan acerca de las cotizaciones de productos (trigo, maíz, girasol, sorgo, soja y cebada) en el Mercado a Término de Buenos Aires (Matba) y de los granos en puertos argentinos y en el exterior (mercado de Chicago, Kansas y FBO golfo de México). También se detalla información sobre los precios 
en pesos de productos a granel en Cámaras Arbitrales y el valor de la soja en el mercado a término de Rosario Rofex.

Dicha información específica hace suponer un sujeto enunciatario interesado en temas económicos, concernientes a la actividad agropecuaria.

La noticia informa sobre el aumento del valor de la oleaginosa en la Bolsa de Comercio de Rosario, la cotización a futuro del mes de julio en el mercado de Chicago y la previsión para la cosecha de granos y oleaginosas del año 2013 en Brasil. Para ello utiliza fuentes textuales institucionales oficiales buscando un efecto de veracidad y como prueba de lo que se dice:

- "En el mercado de Chicago los futuros agrícolas cerraron con subas, impulsados por la acción compradora de los fondos especulativos en la previa a la publicación de un nuevo informe de oferta y demanda del Departamento de Agricultura de los Estados Unidos (USDA, por sus siglas en inglés). Los ajustados inventarios en los Estados Unidos y la firmeza de la demanda sostuvieron los precios de la soja, mientras que la situación climática norteamericana dio sostén a los cereales".

- "Mientras tanto el Instituto Brasileño de Geografía y Estadísticas (IBGE) informó ayer que aumentó su previsión para la cosecha de granos y oleaginosas de 2013, que alcanzará niveles históricos de 185 millones de toneladas, con producción récord de soja y maíz”.

- "Según un despacho de la agencia AFP datado en Brasilia, la cosecha del año superará un $14 \%$ la del año anterior, que ya fue un récord con 162 millones de toneladas. Agrega la información que la producción de soja aumentará 23,3\% este año, para alcanzar 81 millones de toneladas, después de una contracción en 2012 debido a problemas climáticos".

- "Según la Dirección de Informaciones y Estudios Económicos de la Bolsa de Comercio de Rosario, la mercadería en condición fábrica se negoció abiertamente a 1670 pesos por tonelada con descarga en Puerto General San Martín, Villa Gobernador Gálvez, Ricardone, San Lorenzo, Arroyo Seco, General Lagos y Timbúes, diez pesos más que anteayer".

- "En el Mercado a Término de Buenos Aires (Matba) los contratos para los mismos meses se ajustaron en 327,70 y 328,10 dólares por tonelada, con mejoras de 2,30 y 2 dólares, respectivamente". 
Para finalizar, se puede señalar que en la noticia que es objeto del análisis se trata a la soja como una mercancía, que puede venderse o comprarse, y conforme a las predicaciones puede inferirse que el discurso está dirigido a productores de la oleaginosa, acopiadores, industriales (molinos o aceiteras), exportadores e inversores.

Puede observarse además, que el diario La Nación no utiliza estos datos favorables sobre cotización de la soja en las noticias referidas a los reclamos de la Mesa de Enlace; como se verá más adelante en el eje temático $\mathrm{N}^{\circ} 2$ "Las Patronales". Sino que omite estas cifras para presentar la realidad de manera fragmentada y así victimizar al sector agroexportador.

UA 9. La noticia seleccionada para el análisis se ubica en el rubro Economía, en la edición del 14 de mayo de 2013 del diario Página 12 y ocupa alrededor del 65\% de la página 8.

Su título, "Alivio por los dólares de la soja" no especifica quién se siente aliviado, pero al leer el cuerpo de la nota se interpreta que se trata del Gobierno Nacional, como puede observarse en este fragmento: "persiste un problema de escasez en la oferta de dólares, que presiona sobre las reservas internacionales del Banco Central a través de las importaciones y el pago de la deuda externa. De ahí que el Gobierno haya implementado el blanqueo de ahorros en divisas”. Según Verón, este tipo de titulares en los que se enuncia una situación son utilizados generalmente en los semanarios y no en los diarios, donde se anuncia un hecho.

La volanta resalta la cantidad de dinero que ingresó al país por la venta de la oleaginosa: "La semana pasada liquidaron 726 millones y ya llevan 8 mil millones en el año". Mientras que la bajada hace hincapié en que, "La venta de dólares provenientes de exportaciones del agro se aceleró y en el sector esperan que siga en este ritmo hasta mediados de año. Influyeron la buena cosecha de la soja y los atractivos precios internacionales".

La noticia es abordada en términos económicos y se centra en la dinámica de la liquidación de divisas del agro. A diferencia de las UA del diario La Nación que hemos abordado, esta noticia no informa sobre la cotización de la tonelada de soja en los mercados a término ni acusa al Gobierno por las altas retenciones, la inflación o la escalada del dólar paralelo. Sino que, manifiesta la cantidad de dólares que ingresaron hasta el momento en el país y de manera latente, lo importante que resulta para el Gobierno la liquidación de divisas y su empleo en las reservas 
del Banco Central y el pago de compromisos externos. De ahí que evalúa como un "alivio" el ingreso de los dólares por la venta de soja.

El diario otorga la palabra a quien fuera secretario de Comercio Interior, Guillermo Moreno, quien evalúa lo que hubiera sucedido de no haber ingresado al país los dólares por la venta de la soja: "Moreno consideró que la situación política ‘hubiese sido de una gravedad notable si los grandes exportadores hoy no nos estuvieran liquidando las divisas'. 'Estaríamos ante un problema extremadamente serio, pero las están liquidando' agregó. En función de la buena entrada de dólares por esa vía 'no se habla más de no vender soja', señaló el funcionario”.

En lo referido al cuadrado ideológico de van Dijk, las palabras de Moreno también son empleadas para enfatizar información negativa sobre los grandes productores y exportadores, a quienes acusa de poseer intereses contrarios al proyecto nacional y popular que lleva adelante el Gobierno: "Moreno analizó que `los exportadores están emparentados, casados con sus proveedores, que son los socios de la Rural', en relación con la clase terrateniente. 'Por primera vez, diría, se produjo una gran división entre los grandes exportadores y la oligarquía dueña de la soja, que beneficia al proyecto nacional y popular'”.

Por otra parte, se reproduce, a través de una cita indirecta, una declaración de Moreno en donde devela la concentración que existe en el sector agropecuario: "El funcionario también mostró con cifras la concentración que existe en el agro. Detalló que sólo 24 personas jurídicas en el país producen el 40 por ciento del trigo, materia prima de alimentos de consumo popular, al tiempo que el 80 por ciento de la producción de soja pertenece al 20 por ciento de los productores”.

En la noticia, los productores que llamaron a no vender soja aparecen categorizados en función de su situación e intereses económicos, como: "terratenientes nucleados en la Mesa de Enlace", "férreos opositores", "socios de la Rural", "clase terrateniente" y "oligarquía dueña de la soja". Además, se los asocia negativamente a los términos: "boicot", "concentración" y se los responsabiliza de querer generar un "desgobierno".

Por su parte, para mencionar a las empresas exportadoras se utilizan términos relacionados a su potencial económico: "multinacionales", "grandes exportadores" y "corporaciones". Y, se las asocia de manera negativa con barajar "la posibilidad del lockout".

En otro orden de cosas, la noticia predica de manera positiva la relación que el Gobierno mantiene con las empresas de cereales: "El propio Moreno mantiene un buen diálogo con las 
cerealeras. En ese sentido, en el sector destacan como una reunión fundamental, para la tranquilidad del Gobierno, la que se produjo entre las firmas y el secretario a comienzos de abril. Allí le aseguraron que no habría problemas con la liquidación de las divisas, a pesar de la oposición de las corporaciones, que barajaron la posibilidad del lockout”.

En cuanto a la fotografía, se trata de una imagen documental, según la clasificación de Thibault Laulan ya que adhiere a la realidad en sus conexiones esenciales, en este caso por retratar a un buque trasatlántico cargado de containers con soja a granel.

UA 10. "La soja sumó la quinta rueda alcista consecutiva en la Bolsa de Chicago", tituló el diario de los Mitre el 27 de febrero de 2014, en un escenario caracterizado por el atraso en las ventas de la nueva cosecha de la oleaginosa pese a las cotizaciones elevadas del producto en los diferentes Mercados y Bolsas.

Por aquellos tiempos, las pizarras de la Bolsa de Chicago alcanzaron a ofrecer hasta 517,08 dólares por tonelada de soja, como informa la noticia. Pero en octubre del mismo año, con la caída internacional en los precios, la oleaginosa llegó a cotizar a 354 dólares la tonelada. Según la nota "Especuladores hechos bolsa" publicada el 9 de octubre de 2014 en la revista Veintitres, los productores que retuvieron la cosecha en silobolsas "perdieron 1.400 millones de dólares por no haber liquidado antes la cosecha".

El discurso seleccionado se ubica en el extremo superior de la página 16, en el rubro Economía y ocupa un $30 \%$ de su espacio. A su derecha, figura un cuadro con las cotizaciones de los granos a término en el país y en el exterior, y abajo, una noticia que hace referencia a la suba de los precios de la hacienda en el mercado de Liniers; lo que indica la importancia que tiene para el diario La Nación la información sobre los precios del agro.

El título de la noticia enfatiza en la cotización favorable de la soja en la Bolsa de Chicago y la bajada agrega datos sobre el valor del producto en algunos mercados: "Las nuevas mejoras superaron los 3 dólares por tonelada y elevaron el valor de la oleaginosa estadounidense hasta US\$ 517,08 dólares; en Rosario se pagaron hasta 355 dólares”.

El discurso presenta una versión de alta referencialidad que acerca lo más posible a un tema mediante una adecuada cantidad de información y detalles precisos sobre las diferentes cotizaciones de la soja; para ello, utiliza como fuentes textuales institucionales oficiales a las 
bolsas de Chicago, de Comercio de Rosario (BCR) y de Cereales de Buenos Aires y al Mercado a Término de Buenos Aires (Matba). Los datos aportados por dichas instituciones sirven como prueba de lo señalado por el enunciador en referencia a la mejora de los precios de la soja:

- "Las pizarras de Chicago mostraron alzas de US\$3,03 y de 3,58 sobre los contratos marzo y mayo de la soja, cuyos ajustes resultaron de 517,08 y de 513,31 dólares por tonelada".

- "La Bolsa de Comercio de Rosario (BCR) indicó que en operaciones puntuales y por mercadería con entrega inmediata ‘el precio trepaba nuevamente hasta 355 dólares'”.

- "En el Mercado a Término de Buenos Aires (Matba), las posiciones mayo y julio de la soja aumentaron US\$ 0,20 y 1,50, mientras que sus ajustes fueron de 309 y de 313,50 dólares por tonelada".

A lo largo del discurso pueden observarse léxicos que refieren a la situación positiva de los precios de la soja: "sumó", "alcista", "mejoras", "alzas", "saldo positivo" "elevado" y "aumentaron".

Otra fuente textual institucional oficial consultada en su calidad de voz autorizada para aportar datos sobre la cantidad de soja comercializada es el Ministerio de Agricultura de la Nación: "En su nuevo informe semanal de comercialización agrícola, el Ministerio de Agricultura de la Nación indicó ayer que entre la exportación y la industria suman compras de soja 2013/2014 por 4.893.000 toneladas, un $36,68 \%$ por debajo de las 7.727 .700 adquiridas a igual fecha del año anterior. Respecto de la campaña 2012/2013, entre ambos sectores compraron 42.810 .300 toneladas de soja, sobre una cosecha sostenida por el organismo en 49,3 mill./t". En este párrafo es importante resaltar que el diario La Nación reconoce que hacia fines de febrero de 2014 se vendió un 36,68\% menos de soja que en igual período del año anterior y evalúa que "sigue atrasada la venta de soja de la nueva cosecha"; a diferencia del diario Página 12 que califica a la oleaginosa como "retenida" por productores que especulan con una nueva devaluación del peso argentino.

El discurso predica además, sobre una de las causas de la tendencia alcista de la soja en el mercado: "Entre los fundamentos que volvieron a alentar ayer las compras de los fondos especuladores en el mercado estadounidense se destacaron las complicaciones que se registran en Brasil, donde los excesos de lluvias están demorando la cosecha en el estado de Mato Grosso, el 
principal productor de la oleaginosa brasileña. Esta situación, que atenta no sólo contra el volumen, sino contra la calidad, se sumó a las pérdidas potenciales que habría generado la falta de humedad adecuada en determinadas zonas agrícolas del centro-norte de Brasil”. Esto hace presuponer que el discurso del diario La Nación está dirigido a los productores que se dedican o tienen previsto sembrar soja y por este motivo, se brinda un panorama general sobre la situación de la siembra, cosecha y comercialización de la oleaginosa.

UA 11. La noticia seleccionada fue publicada en el diario Página 12, el 8 de abril de 2014 en el rubro Economía. Ocupa alrededor del $70 \%$ de la página 5, sobre la línea de indicatividad y presenta un titular desplegado a modo "bandera" que ocupa todo el ancho de la página. Estos elementos indican que se trata de un acontecimiento jerarquizado por el medio. Su título "Dólares a granel y reservas en calma" enuncia una situación favorable para la economía argentina dos meses después de la devaluación del peso oficial realizada a fines de enero de 2014. Con la metáfora "dólares a granel", el diario alude a la liquidación de divisas provenientes de la venta de productos agrícolas que se comercializan sin empaquetar y en cantidades abundantes. Y, por otra parte, utiliza el subjetivema "en calma" para caracterizar de manera positiva el estado de las reservas del Banco Central.

Si bien el título no resulta del todo informativo, se sustenta en la volanta para explicitar de qué trata la noticia: "Los exportadores de cereales aceleran liquidaciones y se consolida la estabilidad cambiaria”. Mientras que la bajada vuelve a resaltar información positiva sobre la situación de la economía argentina a causa de la exportación de cereales y sus derivados. Por un lado, detalla que, "Las ventas de dólares provenientes de los agroexportadores sumaron 625 millones en la última semana y 5055 millones desde inicios del año". Y, por otra parte, califica como "estable" al mercado cambiario y señala que el Banco Central "recupera reservas".

La noticia utiliza como fuentes a la Industria Aceitera (Ciara), al Centro de Exportadores de Cereales (CEC) y al Banco Central de la Nación Argentina para brindar datos favorables sobre la liquidación de divisas por ventas al exterior y el stock de reservas. Según la clasificación de Lucrecia Escudero las mismas corresponden a fuentes textuales institucionales oficiales y son expuestas para ratificar la palabra del cronista y probar lo que está diciendo con datos suministrados por instituciones que poseen autoridad. Por ejemplo señala: 
- "La liquidación de divisas por ventas al exterior de cerealeras y aceiteras alcanzó la semana pasada a 625,5 millones de dólares, más del doble que en igual período del año pasado, según reportaron la Cámara de la Industria Aceitera (Ciara) y el Centro de Exportadores de Cereales (CEC)".

- "Según datos de Ciara-CEC, los exportadores de granos liquidaron la semana pasada un 109 por ciento por encima de los registros de un año atrás, cuando en el mismo período habían ingresado 299,2 millones de dólares".

- "Según los datos (del Banco Central) al jueves de la semana, con los ajustes contables pertinentes, las reservas finalizaron en 26.729 millones de dólares. Este dato se publica con 48 horas de dilación respecto del comunicado preliminar, que informó ayer que el stock fue de 27.137 millones".

Lejos de describir un panorama caótico, Página 12 alude a la existencia de un momento favorable en la economía argentina por la venta de granos al exterior, que puede observarse en la utilización de los subjetivemas: "estabilidad" y "calma" que describen al mercado cambiario. A diferencia del diario La Nación que alude a una "crisis cambiaria", como veremos en las UA 19, $20,22,24,25$ у 26.

Además, teniendo en cuenta el cuadrado ideológico planteado por van Dijk, Página 12 enfatiza información positiva sobre la liquidación de divisas provenientes de la venta al exterior de ceraleras y aceiteras. Esto puede observarse en:

- El campo semántico de lexemas utilizados para describir la situación del Banco Central: "pudo aprovechar la liquidez del mercado y recomponer reservas", "registró su mayor compra de divisas en dos años", "absorbió 40 millones de dólares", "En febrero recuperó su posición de comprador neto -la última vez fue en junio pasado”. El stock de reservas de 27.137 millones, "permitió reducir el impacto de los pagos de deuda y de importación de energía".

- Y, en el campo de lexemas de las acciones que se producen en el mercado cambiario: "El dólar enlaza su quinta rueda consecutiva sin cambios a 8,01 pesos, mientras que continuó el descenso de la cotización en las transacciones del paralelo, cerrando a 10,60 pesos, debajo del costo para la compra de moneda extranjera con fines turísticos". "La 
calma en el mercado cambiario, donde, más allá de mínimas oscilaciones diarias, la cotización del dólar se mantiene en los 8 pesos, le quitó margen de acción a las cuevas”. Por otra parte, el discurso explica que la liquidación se produjo entre otras causas debido al “compromiso adoptado por el sector durante una reunión que mantuvo en febrero último con el jefe de Gabinete, Jorge Capitanich, y el ministro de Economía, Axel Kicillof. También son influidos por un tipo de cambio alto, tras la devaluación del peso de fines de enero último, y cotizaciones en baja para los commodites". Con cual destaca la gestión del Gobierno Nacional en su intervención para solicitar a las cerealeras la venta de granos y de manera implícita señala que la devaluación del peso oficial favoreció a los productores.

Finalmente, el discurso advierte a los productores rurales que los precios de la producción agropecuaria podrían bajar a nivel mundial: "El escenario para el mediano y largo plazo es a la baja para los precios de los commodities agropecuarios, y en el sector entienden que el juego de retener cosecha podría ser contraproducente. Según estimaciones del sector, la cosecha gruesa de la soja, que se extenderá hasta fines de junio, superará los 53 millones de toneladas, con precios en torno de 540 dólares la tonelada en Chicago". Este pronóstico del diario finalmente se cumplió y si en mayo de 2014 las pizarras de la Bolsa de Chicago llegaron a ofrecer hasta 503,03 dólares por tonelada de soja, en noviembre del mismo año el producto llegó a valer 354 dólares la tonelada. De manera que los productores que guardaron la cosecha en silobolsas se vieron perjudicados por el descenso del valor internacional.

Por otra parte, la noticia está acompañada por una fotografía que retrata el momento de la cosecha en que los granos de soja caen al camión que los acopia, por lo que se trata de una imagen documental e ilustrativa. Mientras que en su epígrafe destaca un dato positivo para la economía del país: "Los exportadores aumentaron el ritmo de liquidaciones en abril, duplicando el de un año atrás”. 


\section{II.2. Las patronales.}

\begin{abstract}
"Así se crean intereses locales que simulan ser nacionales, pero que son de dependencia. Antes hemos hablado del caso de los invernadores, que si bien desarrollan una etapa necesaria de parte de nuestra producción ganadera, aparecen como la única expresión de nuestra ganadería, manejan sus organismos representativos y dirigen la politica de nuestro país, que está en crisis o no está, según les va a ellos, con el apoyo de los grandes diarios y la vocinglería de los llamados 'expertos"”.
\end{abstract}

Arturo Jauretche (2010:100).

UA 12. El discurso que es objeto de este análisis se encuentra en el rubro Economía de la edición del 18 de febrero de 2013 del diario Página 12 y ocupa el 60\% de la página 6, arriba de la línea de indicatividad; lo que denota una manera de jerarquizar el hecho.

El diario titula, en complicidad con el lector que comprende el significado de la palabra que aparece en idioma inglés: "La amenaza del lockout para presionar". Dicha expresión que podría traducirse como "paro patronal" o "cese de las ventas" fue utilizada con asiduidad por éste y otros medios durante el conflicto entre la Mesa de Enlace con el Gobierno Nacional por la Resolución 125 en el año 2008. Se puede inferir además, que se trata de un título editorial, ya que para el diario el posible cese de la venta de soja se produciría para "presionar" a un Gobierno ávido de dólares. En la volanta se amplían los elementos para comprender el hecho: "El titular de la Rural afirmó que los productores evalúan dejar de vender soja". Téngase en cuenta que para van Dijk, lo ideológico se halla representado también en las estructuras esquemáticas globales y lo que aparece en los titulares puede indicar relevancia; más aun cuando se emite una opinión positiva o negativa hacia un sector.

Y, finalmente la bajada aporta elementos para contextualizar el hecho y explicar por qué las cuatro entidades que conforman la Comisión de Enlace proponen el cese de las ventas: "El empresario aseguró que ésa fue una de las propuestas que surgieron en la asamblea que realizó la Mesa de Enlace el viernes, en Pehuajó. Dijo que la medida podría ser por tiempo indeterminado si el Gobierno se niega a recibirlos".

El discurso trata sobre la amenaza de la Comisión de Enlace de Entidades Agropecuarias (CEEA) de "dejar de vender soja a mediados de abril por tiempo indeterminado sino logran avances en la 
negociación con el Gobierno". Y, sobre la decisión de las entidades que integran la Mesa de no aceptar reuniones por separado con el entonces ministro de Agricultura, Norberto Yauhar, quien se ofreció a recibirlos en el mes de marzo, pero de manera individual. Como puede observarse, aparece nuevamente la estrategia de fondo de las relaciones de conflicto, de las que habla Prieto Castillo, pero a diferencia de La Nación, Página 12 señala que esta relación de oposición es entre la Mesa de Enlace y el Gobierno y no entre el "campo" -como sector homogéneo- y el Gobierno.

El discurso predica además, sobre las próximas asambleas que realizará la Mesa de Enlace: “El titular de la Rural indicó que la próxima asamblea de productores se llevará a cabo el $1^{\circ}$ de marzo en la localidad de Roque Sáenz Peña, en Chaco. 'De ahí vamos a ir a Santa Fe, Córdoba, Entre Ríos, para ver si realmente los productores de esas zonas están decididos también a llevar adelante medidas como se planteó en Pehuajó y organizarlas', señaló”.

Se utiliza como fuente las declaraciones radiales (sin mencionar al medio) de Luis Miguel Etchevehere, presidente de la Sociedad Rural Argentina, quien señala lo resuelto en la Asamblea de la Mesa de Enlace realizada en Pehuajó. Para ello, se emplean citas directas e indirectas: "De hecho, aclaró que una de las principales decisiones que se adoptó en la asamblea de productores es 'mantener unida la Mesa de Enlace' y 'no ir a reuniones con el ministro (de Agricultura, Norberto Yauhar) que sean por separado'. ' (Se decidió) ir todos juntos, por los problemas en común que hay', agregó. El ruralista sostuvo entonces que la principal propuesta fue realizar un cese de comercialización de soja. `Paro por tiempo indeterminado o por el plazo que se decida', aseguró".

Por otra parte, reproduce la palabra del presidente de la Rural, como voz autorizada, refiriéndose a la participación de referentes agropecuarios en la política: "De cara al año electoral, Etchevehere destacó que desde la dirigencia agraria van a `seguir propiciando la participación en política, en el partido que elijan los productores, no como sector, sino como ciudadanos que somos de Argentina. Nos parece que nuestra visión mezclada con la visión de otras personas que participan en política puede ser un gran aporte al país', alegó."

Al momento de explicar las causas del posible cese de las ventas, Página 12 las enuncia sin reproducir a través de citas directas la palabra del titular de la Rural, como lo hace el diario La Nación en las UA 14 y 15. De esta manera, se exponen las causas de manera descriptiva 
omitiendo los comentarios y evaluaciones negativas de Etchevehere hacia el Gobierno: "Los ruralistas cuestionan la política agropecuaria, la decisión oficial de querer anular la cesión del predio de Palermo a la Sociedad Rural, la eliminación de los formularios de inscripción de operaciones granarias, que para Federación Agraria representaba un negocio de diez millones de pesos anuales, y la disolución del ex Renatre, que era manejado por Gerónimo 'Momo' Venegas. Además, denuncian que la AFIP los presiona para que vendan la soja que tienen acumulada en los silo-bolsas".

De acuerdo a lo planteado por Ana Atorresi en lo referido a la polifonía, la estrategia de mencionar los temas sin otorgarle la palabra al referente de la Rural, conlleva sin dudas una marca ideológica.

UA 13. La presente unidad de análisis se halla dispuesta en la página 13 del rubro Economía, en la edición del jueves 28 de febrero de 2013 del diario Página 12. El hecho de ubicar la noticia en una sección fija a la que el periódico le otorga relevancia y de dedicarle alrededor del $60 \%$ de la página mencionada, es una primera forma de categorizar y valorar el acontecimiento.

Su título, "Compromiso de los sojeros" no es puramente informativo, debido a que enuncia una situación, pero se apoya en los demás elementos de lectura rápida para poder comprenderse. De este modo, en la volanta se resalta que, "Prometieron liquidar 1600 millones de dólares en treinta días", dejando al descubierto que existe una millonaria suma de granos sin comercializar. Mientras que la bajada señala: "Los empresarios se reunieron ayer con Guillermo Moreno, y le dijeron que tratarán de acelerar la liquidación de divisas. Al 24 de febrero se liquidó un 30 por ciento menos que hace un año".

El discurso trata sobre una reunión entre el entonces secretario de Comercio Interior, Guillermo Moreno y los representantes de la Cámara de la Industria Aceitera (Ciara) y del Centro de exportadores de cereales, en la que las empresas exportadoras de soja se comprometieron a liquidar 1600 millones de dólares en 30 días. Y, agrega además que, "Según un informe de esta cámara, al 24 de febrero se había liquidado un 30 por ciento menos de divisas que hace un año. Esto obedeció a cierta especulación por parte de los productores y la industria vinculada con los movimientos en el tipo de cambio". Como se podrá apreciar en la UA 20, correspondiente a la noticia que elabora el diario La Nación sobre el mismo hecho, el periódico de los Mitre interpreta 
que los productores de soja retienen la comercialización de la oleaginosa "para hacer frente a inversiones como la siembra de trigo y otros gastos relacionados con su actividad"; es decir, que la utilizan como un ahorro.

En cuanto a la polifonía de voces, el diario emplea fuentes textuales institucionales oficiales que buscan un efecto de realidad a través de la palabra autorizada:

- "Se hizo un repaso del proceso de comercialización de la soja y derivados en marcha. Estuvieron representadas el 90 por ciento de las empresas exportadoras y comercializadoras del sector', expresó Alberto Rodríguez, titular de Ciara. Según un informe de esta cámara, al 24 de febrero se había liquidado un 30 por ciento menos de divisas que hace un año".

- "Un informe del Banco Ciudad, entidad presidida por el macrista Federico Sturzzeneger, había dicho que `el retraso que experimenta la siembra de granos demorará la liquidación de divisas hasta mediados de mayo, hecho que generará una mayor tensión en el mercado cambiario local'",

Por otra parte, el diario evalúa de manera positiva que, "De concretarse el pedido de Moreno, las liquidaciones de divisas llegarán antes, y con ellas cierto alivio sobre la presión en el tipo de cambio".

Cabe señalar además, que a diferencia del diario La Nación, en Página 12 se alude a las empresas que estuvieron presentes en la reunión y se explica cuántas toneladas de soja vendieron algunas de ellas en el bienio 2011-2012:

- "Allí estuvieron los directivos de Bunge, Cargill, Molinos, Vincentin, Dreyfus, Aceitera General Deheza, y de la Asociación de Cooperativas Argentinas (ACA), una entidad vinculada con Coninagro, una de las patronales agropecuarias que forman parte de la Mesa de Enlace".

- "En cuanto al segmento exclusivo de granos, sin contemplar aceites ni subproductos, Cargill pasó de vender 6,2 millones de toneladas en 2011 a 5,9 millones en 2012. Su participación en el mercado pasó de 16,3 al 14,64 por ciento. Otra empresa que cedió participación en este segmento de mercado fue Dreyfus. En 2011 exportó granos por 4,8 millones de toneladas, con una participación de 12,6 por ciento. Al año siguiente, sus ventas fueron de 4,1 millones de toneladas, con una participación de 10,18 por ciento. 
También se encuentran los casos de ADM, cuya participación en el mercado pasó del 12 al 11,24 por ciento, y Nidera, cuya participación cayó un punto porcentual".

En cuanto a la imagen, se trata de una fotografía que documenta a los representantes de las empresas exportadoras de soja y en especial al presidente de Ciara, como lo señala el epígrafe: “Alberto Rodríguez, titular de Ciara (en el extremo derecho), luego del encuentro con Moreno".

UA 14. La noticia que es objeto de éste análisis, se encuentra ubicada en la página 18 del rubro Economía del diario La Nación, en su edición del 21 de marzo de 2013. El hecho de categorizar la noticia sobre una asamblea de la Comisión de Enlace en una sección tan importante para el periódico, es una primera forma de clasificar y valorar el acontecimiento. Se puede inferir además, que para el centenario diario las entidades que forman parte de la Mesa de Enlace juegan un papel trascendental en la economía del país, por el ingreso de divisas producto de las exportaciones y por el movimiento de capital en el mercado interno.

En el título "Aumenta el malestar del campo con el Gobierno", puede observarse que para el diario La Nación la totalidad del sector agrario se encuentra representado en las cuatro entidades que conforman la Comisión de Enlace de Entidades Agropecuarias (CEEA): Sociedad Rural Argentina, Confederaciones Rurales Argentinas (CRA), Federación Agraria Argentina (FAA) y Coninagro; cuando el campo está conformado también por agricultores familiares, pueblos originarios, cooperativas, etc., nucleados a su vez en otras asociaciones.

Cabe señalar además, que en el título se hace alusión a una "relación de oposición" entre el “campo" y el Gobierno, que aparecerá desarrollada a lo largo de la noticia. Según Prieto Castillo (1999: 97), esta estrategia de fondo del discurso es una constante en los medios de comunicación. "El hecho de centrarse en seres, situaciones, ideologías, ambientes opuestos, no es casual; las relaciones sociales son conflictivas", indica el autor. De igual modo, se trata de un título editorial, en el que se enuncia una situación.

La bajada, brinda datos contextuales del acontecimiento y resalta la inoperancia del Gobierno Nacional hacia los pedidos del sector agropecuario: "Asamblea. En un nuevo encuentro de productores, esta vez en Río Cuarto, hubo reclamos a la falta de respuestas oficiales".

El primer párrafo vuelve a predicar que el Gobierno hace caso omiso a los reclamos del sector agropecuario y que los ánimos de éste último están cada vez más caldeados: "El ánimo en los 
productores agropecuarios de base se va crispando a medida que las respuestas oficiales que demandan no llegan. Así se notó ayer en una nueva asamblea convocada por la Comisión de Enlace de Entidades Agropecuarias (CEEA), realizada en la Sociedad Rural de Río Cuarto, Córdoba, y a la que asistieron más de 1000 personas".

La noticia utiliza como fuentes a las cuatro entidades de la Mesa de Enlace para expresar información negativa sobre el Gobierno Nacional a quien acusan de llevar adelante “desacertadas políticas macroeconómicas” y para victimizar al sector agropecuario por el pago de impuestos:

- "No podemos cargar sobre las espaldas del campo todo el peso de la recaudación impositiva, ni mucho menos el peso del descontrolado gasto público ni el de las desacertadas políticas macroeconómicas', dijo en el encuentro de ayer el presidente de la Sociedad Rural Argentina, Luis Miguel Etchevehere".

- "Por su parte, el presidente de Confederaciones Rurales Argentinas (CRA), Rubén Ferrero, explicó que `existe una gran necesidad de los productores de movilizarse por la delicada situación que atraviesan con una notoria pérdida de rentabilidad y competitividad que hace que se trabaje muchas veces a pérdida'”,

- "Por su parte, Eduardo Buzzi, presidente de la Federación Agraria Argentina (FAA), señaló: ‘Para los productores agropecuarios, estos diez años de kirchnerismo han sido una década perdida'”.

- "En tanto, el presidente de Coninagro, Carlos Garetto, instó a los productores ’a seguir participando de las entidades representativas, para hacer escuchar la situación y las necesidades de nuestros pares, hombres y mujeres de campo que trabajan en pos de seguir manteniendo la actividad como el motor de las economías de nuestros lugares de origen'. Y concluyó: 'Acá no hay diáspora, acá hay unidad de los productores y sus entidades representativas'",

En cuanto a la lexicalización, La Nación emplea las siguientes palabras para nombrar a la Comisión de Enlace: “campo", "productores” y "productores agropecuarios”. Como podrá verse a lo largo de la investigación, la estrategia de presentar al campo como una unidad sin estamentos que posee los mismos intereses, es una constante en las noticias de La Nación y va 
aparejada de presentar a la Mesa de Enlace como una entidad fuerte y legítima que representa al sector.

El texto está acompañado de una imagen que documenta a los referentes de la Comisión de Enlace: Garetto, Etchevehere, Bagni, Ferrero y Buzzi en la Asamblea de Río Cuarto.

UA 15. La unidad seleccionada se ubica en el rubro Economía del diario La Nación en su edición del 26 de marzo de 2013; ocupando el 45\% de la página 14. Como ya se observó en la UA11, el centenario diario categoriza las noticias sobre la Mesa de Enlace en el rubro Economía y no en otras como Política, a pesar de que el Gobierno forme parte del quién en la noticia. Esto denota que para el diario de los Mitre, la soja es una mercancía y el sector agrario juega un rol muy importante en la economía del país.

Por la cantidad de espacio que el periódico le otorga al tema puede inferirse además, que las decisiones, acciones y opiniones de la Mesa de Enlace, son consideradas noticiables.

En el título "Rechazan los ruralistas la posible aplicación de la ley antiterrorista", pueden señalarse dos aspectos; el primero es que el verbo antecede al sujeto para resaltar la acción y el segundo es que, como ya se observó en la UA 14, el diario presenta a los productores como un sector homogéneo que posee los mismos intereses, cuando diferentes estudios han demostrado que se trata de un sector diverso, estratificado y mucho más complejo de lo que el matutino nacional pretende describir.

La bajada, por su parte, amplía los datos del título y contextualiza el hecho brindando información positiva sobre el sector: "En una asamblea, dirigentes de la Mesa de Enlace dijeron que los productores ya vendieron la soja de la campaña pasada y que la actual apenas comenzó a ser cosechada". De manera latente se intenta señalar que no hará falta sancionar la ley antiterrorista debido a que los productores ya vendieron la soja de la campaña anterior y que recién comenzaron a cosechar la actual.

El discurso seleccionado trata sobre una asamblea de productores organizada en Tucumán por la Mesa de Enlace en la que, "rechazaron la posible utilización de la ley antiterrorista por parte del Gobierno para obligar a los productores agropecuarios a vender soja y enfrentar así la crisis cambiaria", como señala el primer párrafo. 
Al igual que en la UA 14, en este discurso aparece una relación de oposición y conflicto entre los ruralistas y el Gobierno de Cristina Fernández de Kirchner. En este sentido, es importante remarcar que el periódico La Nación se inclina por resaltar los reclamos de los ruralistas y reproducir las descalificaciones de la Mesa de Enlace hacia el Gobierno.

En lo referido a las fuentes, se menciona al diario El Cronista Comercial, que en su edición del 25 de marzo de 2013 señaló que según "fuentes no consignadas pero con acceso a despachos oficiales, el texto de la ley comenzó a ser analizado por el Gobierno con el propósito de presionar a exportadores y productores a vender soja ante la escasez de divisas".

La palabra del "otro" también se emplea para victimizar al sector productivo:

- "Por su parte, el diputado nacional y productor Juan Casañas (UCR-Tucumán) dijo que los productores del NOA 'corren con desventaja'. El legislador expresó: 'Las retenciones, las distorsiones y el valor de los fletes nos duelen mucho más a los productores de aquí que a los de la pampa húmeda. Por eso necesitamos políticas especiales, como la compensación del flete'”.

- “A los productores de azúcar de Tucumán les bajaron el precio que les pagaban en la cosecha el año pasado, mientras que en la góndola del supermercado el producto pasó de 6,50 a 7,60 el kilo desde fin de 2012 hasta ahora', dijo Ferrero" (presidente de CRA).

Asimismo, se emplea como fuente la palabra de los presidentes de las entidades que conforman la Mesa de Enlace, en calidad de fuentes institucionales autorizadas, con el fin de expresar información negativa sobre el Gobierno Nacional y de defender sus intereses de grupo:

- “Es una práctica fascista', denunció el presidente de la Sociedad Rural Argentina (SRA), Luis Miguel Etchevehere. Para el dirigente, el Gobierno `quiere controlar todo lo que sea industria, comercio y producción'”.

- "Para el presidente de Confederaciones Rurales Argentinas (CRA), Rubén Ferrero, la posible aplicación de esa norma contra productores es 'un apriete más del Gobierno', en referencia a inspecciones que realizó la AFIP en campos y acopios durante enero y febrero pasados. El dirigente dijo que la soja de la campaña pasada ya fue vendida y que de la actual recién comienza a ser cosechada. 'Es inaplicable esa ley' para la producción, expresó”. 
El diario emplea además, la palabra autorizada del jefe de la Administración Federal de Ingresos Públicos (AFIP), Ricardo Echegaray, para desatar la polémica y negar las versiones sobre la aplicación de la ley antiterrorista: "dijo respecto del posible uso de la ley antiterrorista que `las versiones corren por cuenta del diario que las publicó y que el organismo a su cargo ‘sólo aplica la ley penal tributaria'”".

Por otra parte, La Nación minimiza las declaraciones de Echegaray cuando denuncia las deudas millonarias que mantienen las empresas cerealeras con el Estado argentino: "El funcionario, además, criticó a las cerealeras y dijo que mantienen una deuda con el fisco. 'Cargill debe 228 millones de dólares; Bunge, 126 millones; LDC, 141 millones; Aceitera General Deheza, 48 millones; Molinos, 197 millones; Nidera, 132 millones; Vicentín, 62 millones, y Oleaginosa Moreno, 17 millones de dólares', dijo el funcionario". Y cierra la nota señalando que, "Los exportadores rechazan esa acusación", sin investigar o ahondar en el tema, en ésta u otras ediciones.

Cabe señalar que las declaraciones del funcionario nacional no se encuentran incluidas en el cuerpo del texto sino en un destacado en el medio del discurso que lleva el subtítulo "La AFIP contra las cerealeras". Expresión editorial que evalúa la existencia de una supuesta animosidad del Estado contra un sector del agro, cuando en realidad dicho sector se encuentra infringiendo sus obligaciones fiscales. De este modo, se puede inferir que el diario La Nación avala el accionar de las cerealeras que infringen la ley y las describe como víctimas de un Gobierno que se ensaña con ellas.

En este discurso, el Gobierno aparece asociado a proposiciones, predicaciones y léxicos negativos: "fascismo", "crisis cambiaria", "quiere controlar todo lo que sea industria, comercio y producción”, “comenzó a analizar la ley antiterrorista para presionar a exportadores y productores a vender soja ante la escasez de divisas", "la posible aplicación de esa norma es 'un apriete más del Gobierno'”, "posee una actitud de revanchismo hacia el sector agropecuario".

Por otra parte, predica que, "Frente a la Sociedad Rural de Tucumán, además, hubo pintadas de La Cámpora con la leyenda ‘democracia o corporación'”. Señalando de manera implícita el hostigamiento hacia el sector agropecuario por parte de grupos cercanos al Gobierno. 
Puede observarse también que, al igual que en otras unidades de análisis, se utiliza el recurso de la universalización para expresar que los "ruralistas" están representados en las cuatro entidades que conforman la Mesa de Enlace.

En cuanto a los subjetivemas, se emplea un evaluativo axiológico para victimizar a los ruralistas al señalar que atraviesan una “crítica situación”. Según van Dijk, la figura retórica del epíteto (adjetivo delante del sustantivo) es empleada para dar énfasis a los significados en función de opiniones ideológicas.

Por otra parte, en lo referido a la lexicalización, se emplea las siguientes palabras para mencionar a los productores: "ruralistas", "productores agropecuarios" y "miles de productores".

Para finalizar, la imagen que acompaña a la noticia documenta un momento de la asamblea con Etcheverre (SRA), Ferrero (CRA), Buzzi (FAA) y Garetto (Coninagro) en el estrado. También puede observarse un cartel de grandes dimensiones que reza, "Sociedad Rural de Tucumán, $1908 \%$.

UA 16. El discurso seleccionado se encuentra en la edición del 12 de junio de 2013 del diario Página 12, en las páginas 12 y 13 del rubro Economía, formando una falsa central. La cantidad de espacio que ocupa- alrededor del 10\% de la primera página y el $90 \%$ de la segunda- y la extensa fotografía que retrata a los cuatro referentes de la Mesa de Enlace, indican la importancia que el periódico le otorga al acontecimiento.

En el título, "Nuevo lockout contra las retenciones" se omite al sujeto de la oración, lo que en gramática se conoce como "sujeto tácito". No obstante, al utilizar la expresión en inglés "lockout", el lector puede presuponer que se trata de la Mesa de Enlace. Cabe destacar que en este elemento de lectura rápida se hace foco en la verdadera intención de los ruralistas: suspender los impuestos por la venta de productos del agro al exterior.

La volanta aporta datos sobre el contexto y menciona a la entidad que promueve la medida de fuerza: "La Mesa de Enlace hará su protesta entre el sábado 15 y el miércoles 19 próximos". Mientras que la bajada resalta por un lado, la existencia de fracturas en el interior de dos organizaciones que conforman la mesa, lo que señala de manera implícita que no todos sus integrantes están de acuerdo con las decisiones adoptadas y por otra parte, que la demora de las ventas será en un plazo menor que el anunciado días atrás: "Las cuatro entidades que conforman 
el bloque rural llamaron a un cese de comercialización más corto que lo anticipado, con divisiones internas en Coninagro y Federación Agraria. Reclaman el fin de los derechos de exportación y otra política ganadera".

Página 12 emplea palabras propias del lenguaje cotidiano que resultan informales para la redacción del género informativo pero que ayudan a captar la atención de los lectores y demuestran la complicidad que existe entre enunciador y enunciatario: "Los ruralistas suelen decir que...", “... muy lejos de la semana completa de lockout que habían preanunciado", "Luego de ese faltazo..." y "El gran ausente del encuentro...".

El discurso utiliza además, fragmentos de la conferencia de prensa realizada por la Mesa de Enlace, en donde intervienen el periodista y Julio Currás, de Federación Agraria:

-“En febrero de este año, el Consejo Directivo de FAA mandató a la conducción de la entidad para asistir a una reunión con Yauhar, por fuera de la Mesa de Enlace. ¿Por qué desoyeron ese mandato? -preguntó este diario a Julio Currás”.

-“En realidad, lo que pasó fue que podíamos ir solos en el caso de que el resto de las entidades hiciera lo mismo. Como ninguna había aceptado la invitación, no fuimos respondió Currás".

Como puede observarse, la palabra "del otro" es empleada a fin de demostrar en primera medida, que existen fracturas en el seno de la FAA; por otro lado, que el diálogo con el Gobierno no está cerrado como argumentan las entidades del agro y finalmente que, las organizaciones no aceptarán asistir a reuniones por separado de la mesa que integran.

A lo largo del discurso se emplean fuentes textuales institucionales oficiales con fines polémicos. El periódico introduce la voz autorizada de las entidades rurales para luego confrontarlas con informes provenientes de otras fuentes y datos de la realidad que demuestran el buen momento que atraviesa el sector:

- “La soja ha dejado de ser negocio, porque aumentó la inflación y la alta presión tributaria', manifestó Currás. Según un informe publicado en el sitio web Economía del Bicentenario, a septiembre de 2012, un productor propietario de su tierra obtuvo una rentabilidad bruta que osciló entre un 130 y 200 por ciento. Y para el caso de los productores que tuvieron que arrendar, el margen fue de 53 por ciento”. 
- "Otra variable que incide en la rentabilidad agropecuaria son los costos de los insumos básicos para la cosecha. Los ruralistas suelen decir que parte de sus problemas se deben al aumento constante de costos. Sin embargo, este argumento no apareció plasmado en el comunicado. Según un trabajo de la Corriente Agropecuaria Nacional y Popular (Canpo), en base a datos de la revista especializada Márgenes Agropecuarios, los costos de los insumos de la campaña 2013-2014 bajaron en comparación con la cosecha anterior".

- “Esta no es una medida conspirativa ni golpista. Hace un año y medio que vimos a Yauhar (ex ministro de Agricultura). No nos atiende. Vemos al Gobierno inmóvil frente a los problemas. Este es un paro (lockout patronal) más. No descartamos ninguna otra medida gremial', sostuvo Etchevehere. Sin embargo, el ministro del área convocó a las entidades, por separado, cuatro veces. Ninguna quiso asistir por separado”.

- "Sin querer ser irrespetuosos con la investidura presidencial, queremos soluciones concretas. Una política agropecuaria en serio', manifestó Rubén Ferrero, titular de CRA. La Mesa de Enlace indicó que existe una dispersión de precios entre lo que recibe un productor y lo que se paga en las góndolas. Pero como pedidos concretos, los ruralistas reclamaron una baja masiva de retenciones hasta 'su eliminación total' y un aumento del mínimo no imponible en el Impuesto a las Ganancias y Bienes Personales”.

Como fuentes utiliza también dos comunicados, uno de la Mesa de Enlace donde revelan el verdadero motivo de la nueva protesta (a) y otro de la agrupación La Netri en donde se demuestran las internas de la FAA (b):

a). "Hay que disminuir las retenciones hasta su total eliminación y mientras existan, segmentarlas, eliminar los ROEs e implementar un Programa Ganadero Integral con objetivos a largo plazo que permitan recuperar el stock para normalizar la explotación de carne vacuna y recuperar los mercados que perdimos por tanta sinrazón'. Este es el anteúltimo párrafo del comunicado redactado antes de la conferencia de prensa realizada en la sede porteña de FAA. Estas palabras dan cuenta del principal objetivo de los ruralistas desde la resolución 125 hasta el momento, la eliminación de todos los derechos de exportación”. 
b). "Luego de ese faltazo, los integrantes de la agrupación La Netri, que busca disputarle poder a Buzzi, publicaron un comunicado criticando la actitud de la conducción federada. 'Queremos afirmar nuestra posición de respeto a las instancias orgánicas de la entidad y nuestra profunda preocupación ante la actitud de la actual conducción de desoír el mandato del Consejo Directivo', indicaron a través de su comunicado”.

Por otra parte, puede observarse que el discurso seleccionado presenta una versión de alta referencialidad -estrategia de fondo planteada por Prieto Castillo- que acerca lo más posible a un tema, mediante una adecuada cantidad de información.

En otro orden de cosas, el discurso de Página 12 expresa de manera implícita que la Mesa de Enlace no es una organización sólida que representa plenamente los intereses de las entidades que la componen, ya que en interior de las instituciones existen fracciones que replantean las decisiones de las mismas y su participación en la Mesa, como es el caso de la FAA y Coninagro:

"El titular de Coninagro, Carlos Garetto, reconoció la fuerte interna que está atravesando la entidad que preside. A través de un comunicado, les recomendó a las federaciones que forman parte de la entidad pero que no comulgan con la conducción -alineada a la Mesa de Enlace- que den un paso al costado. 'Frente a la actual coyuntura, hemos decidido pedirles a la federaciones que analicen su desvinculación', puede leerse en el comunicado. Esta es la primera vez que la conducción de Coninagro hace público su conflicto interno. En la Federación Agraria también existen pujas. Su titular desde hace catorce años, Eduardo Buzzi, logró desplazar a varios de sus colaboradores cercanos durante el conflictivo 2008, quienes pasaron a integrar los distintos frentes de oposición, como La Netri o Grito de Alcorta".

Y, por otra parte, el discurso deja entrever que las medidas adoptadas para la protesta no poseen la misma fuerza que tuvieron durante el conflicto por la Resolución 125 y que son más bien "simbólicas":

- “La Mesa de Enlace realizará un nuevo lockout entre el sábado 15 y el miércoles 19 próximos. La medida de fuerza sólo abarcará tres días hábiles, muy lejos de la semana completa de lockout que habían preanunciado horas antes a la conferencia de prensa de ayer. Es decir, el llamado al cese de comercialización para todas las producciones agropecuarias, a excepción de los alimentos perecederos, será 'simbólico', aunque los 
ruralistas aclararon que si la presidenta Cristina Fernández de Kirchner no les da `alguna solución', profundizarán la protesta".

Por otra parte, en la imagen que acompaña al texto aparecen Carlos Garetto de Coninagro; Rubén Ferrero, de CRA; Julio Currás, de Federación Agraria y Luis Etchevehere, de la Sociedad Rural, en el marco de la reunión de la Comisión de Enlace de Entidades Agropecuarias llevada a cabo en la sede de la Federación Agraria Argentina. Se trata de una fotografía instantánea en la que los personajes se encuentran tomando asiento detrás de una mesa que haría las veces de estrado y a pesar de su informalidad documenta el hecho.

UA 17. El discurso seleccionado se encuentra ubicado en las páginas 4 y 5 (a modo de falsa central) en el rubro Economía del diario Página 12, en su edición del 18 de julio de 2013. Posicionar el acontecimiento en las primeras páginas y dedicarle el 70\% del espacio mencionado son maneras de jerarquizar la noticia.

El título, "Abre las puertas con cosecha y quejas récord"; por un lado, omite al sujeto del cual hace referencia y por otra parte, aparece la figura retórica de la paradoja, a través de la cual se unen dos ideas contradictorias en un mismo pensamiento. Es decir, presenta dos variables para señalar de manera implícita que pese a los elevados resultados de la producción, hay abundantes reclamos.

La volanta menciona al sujeto que en el título es tácito y brinda detalles espacio- temporales para comprender el hecho: "La Sociedad Rural inicia hoy su tradicional exposición en Palermo, con un discurso crítico al gobierno nacional".

Por su parte, la bajada plantea una contradicción entre la realidad del sector productivo y el discurso de la Mesa de Enlace: "A pesar de que los indicadores de rentabilidad y producción agropecuaria evidencian que el sector rural sigue disfrutando de una etapa de fuerte expansión, los dirigentes de la Mesa de Enlace endurecen sus críticas al Gobierno”.

Cabe destacar que los elementos de lectura rápida adelantan la existencia de una relación conflictiva entre la Sociedad Rural y el Gobierno Nacional y develan que esta oposición se lleva adelante pese a la rentabilidad agropecuaria y al contexto de expansión que atraviesa el sector rural. 
A lo largo de la noticia, Página 12 expresa de manera implícita que las críticas al Gobierno por parte del sector agropecuario son en vano, debido a que el campo atraviesa por una situación de bonanza.

El discurso manifiesta de manera irónica que, "El dirigente de la SRA, como el resto de los integrantes de la Mesa de Enlace, viene repitiendo desde hace cinco años el mismo latiguillo: ‘El campo no da para más'”. Y, seguidamente, Página 12 refuta este argumento señalando que, "la cosecha 2012-2013 alcanzó un record histórico, con 105 millones de toneladas, donde se destacaron el maíz, la soja y la cebada".

En otro orden de cosas, utiliza la estrategia de la interrogación para poner en duda el argumento brindado desde sectores políticos cercanos al agro: "Rápido de reflejos, el ruralista del PRO Jorge Srodek recalcó que el resultado de la actual campaña fue solamente gracias al "esfuerzo de los productores'. ¿Será así?”.

En cuanto a las fuentes, utiliza informes y la palabra autorizada de economistas para refutar las versiones dadas por la Mesa de Enlace y demostrar el contraste que existe entre las quejas emitidas por las patronales y el buen momento que transita el agro argentino:

- "Según un informe de la Cátedra Nacional de Economía Arturo Jauretche, la rentabilidad para los productores-propietarios de tierras se incrementó desde la salida de la convertibilidad hasta la actualidad en un 223 por ciento, mientras que para los arrendatarios los beneficios tuvieron una suba del 690 por ciento".

- 'Un trabajo realizado por Ernesto Mattos (Cemop), titulado 'Las corporaciones agrarias y la presión tributaria', analizó la situación de la zona núcleo de la provincia de Buenos Aires, puntualmente sobre el Inmobiliario Rural. 'Mientras el sector agropecuario que se vincula a la producción de soja para exportación sólo aporta a la recaudación un 11 por ciento (2012), por utilizar la tierra sólo aportaron un 3,25 por ciento en relación con la recaudación total de impuestos', indicó Mattos".

- 'Los hombres de la Rural reclaman por un tipo de cambio alto, una devaluación, pero no dicen nada del costo de los arrendamientos que cobran. Hubo un fuerte incremento de los alquileres de la tierra que tiene un duro impacto sobre los agricultores de menor tamaño", sostiene Nicolás Zeolla, economista de la cátedra Jauretche. 
Nuevamente, se trata de un discurso de alta referencialidad que acerca lo más posible a un tema, utilizando una adecuada cantidad de información, a diferencia de los discursos de baja referencialidad de La Nación, donde la versión ofrece unas pocas notas de algo con la intención de que con ellas se agote todo.

Por otra parte, predica que los ruralistas tienen la intención de que el Gobierno elimine las retenciones: "Durante el último lockout patronal, la Mesa de Enlace-SRA, Federación Agraria, CRA y Coninagro- reclamó la eliminación total de las retenciones, su viejo anhelo desde aquella madrugada de 2008. Para justificar este reclamo, sostuvo que la presión tributaria para el sector es una de las más fuertes de la región".

Y, finalmente, respecto a la fotografía, se trata de una imagen que documenta la inauguración de la Rural en año 2012; acto presidido por Hugo Biolcati, entonces presidente de la Sociedad Rural y Mauricio Macri, jefe de Gobierno porteño.

UA 18. "La Rural también quiere pescar", titula el diario Página 12 en su edición del 17 de abril de 2014. El acontecimiento está ubicado en el rubro Economía y ocupa un 30\% de la página 12, en su costado inferior, por debajo de la línea de indicatividad. Estos factores indican que el periódico no le brinda tanta relevancia al acontecimiento.

El título no resulta informativo; el lector debe avanzar hasta los últimos párrafos de la noticia para comprender lo que el periodista desea manifestar. Con esta expresión se alude a que la Sociedad Rural busca que la Corte Suprema de Justicia de la Nación declare la inconstitucionalidad de las retenciones como ocurrió en 2002 con una medida implementada por el Ministerio de Economía que establecía alícuotas a la actividad pesquera.

Página 12 titula de manera informal, en complicidad con su lector que acepta enunciados poco informativos pero que a su vez resultan atractivos y despiertan su curiosidad. La volanta resulta más explicativa y agrega elementos para la comprensión del hecho: "Presentación judicial por las retenciones".

La noticia trata sobre la presentación de una demanda realizada por la SRA en el Juzgado de Primera Instancia en lo Contencioso Administrativo Federal $\mathrm{N}^{\mathrm{o}} 11$ que solicita la "inconstitucionalidad" de los derechos de exportación agropecuarios "luego del fallo de la Corte Suprema que estableció que las retenciones son 'tributos' que deben ser fijados por el Congreso”. 
En el discurso aparece descripta una relación de conflicto entre la Sociedad Rural, que busca invalidar las retenciones y la Corte Suprema de Justicia que ya falló a favor de la implementación de este tributo. En esta relación de oposición, el discurso descalifica a la SRA al señalar que a pesar de la existencia de un fallo de la Corte a favor de las retenciones, "desplegó su arsenal retórico en contra de los derechos de exportación agropecuarios" argumentando que las retenciones son "confiscatorias" y que su actual aplicación "viola la división de poderes".

En el discurso se cita un comunicado de la SRA para luego polemizar y cuestionar sus argumentos: "La acción judicial de la Fundación SRA se fundamenta en la violación de otros principios constitucionales tales como el derecho de propiedad (por confiscatoriedad), la igualdad ante la ley, la razonabilidad y proporcionalidad y la división de poderes. Sin embargo, su primer argumento para impugnar las retenciones fue la violación del principio de legalidad por el Poder Ejecutivo, castigada por el reciente fallo de la Corte Suprema', sostuvo la Sociedad Rural a través de un comunicado, y agregó que 'el fallo de la Corte refuerza el reclamo del campo'”.

En contrapartida con estas expresiones, el enunciador toma como fuente textual institucional oficial el fallo del máximo órgano judicial en donde se expide a favor de la medida dispuesta por el Congreso de la Nación al considerar que posee atributos positivos para la economía del país: "Sin embargo, la Corte también especificó que los derechos de exportación son `instrumentos estatales de política económica' que pueden utilizarse para 'proteger la producción local, los precios en el mercado interno o las condiciones de competitividad'". De igual modo, otorga la palabra al diputado oficialista, Jorge Landau, que se manifiesta a favor del procedimiento llevado adelante para la aprobación de las retenciones y por lo tanto, desacredita las expresiones de la SRA que señala una supuesta "violación a la división de poderes": "Las retenciones agropecuarias aplicadas por el Poder Ejecutivo son facultades delegadas ratificadas por el Congreso de la Nación. 'Se las aprobó para que el Estado no pueda ser cuestionado', sostuvo a Página/12 el diputado Jorge Landau (FpV)".

Por otra parte, el diario explica que, "la Corte declaró la inconstitucionalidad de una resolución del Ministerio de Economía que establecía retenciones a la actividad pesquera. Pero sólo lo hizo por los pocos meses que fueron desde el dictado de dicha resolución, en marzo de 2002, hasta que el Congreso convalidó las decisiones adoptadas por el Ejecutivo, en agosto del mismo año". Este 
párrafo (el anteúltimo de la noticia) sirve para comprender el título del discurso, como señalamos anteriormente.

En lo que respecta a la fotografía, es ilustrativa. La misma retrata una máquina cosechando soja y su epígrafe señala: "La entidad agropecuaria pide eliminar las retenciones".

UA 19. La noticia titulada, "Para el campo no hay avaricia en la venta de granos, sino prudencia" fue publicada en el rubro Política del diario La Nación, en su edición del 1 de febrero de 2014. Ocupa alrededor del $15 \%$ de la página 12 y se sitúa a la derecha de la noticia que lleva como título, "Capitanich acusó a productores de 'amarrocar' la cosecha y dijo que se busca desestabilizar", que se examinará más adelante en la UA 24.

El título de La Nación se basa en una generalización al señalar que "el campo", en su totalidad y como unidad homogénea, desmiente tener una actitud avara y alega que se trata más bien de una actitud prudente. A medida que se avanza en la lectura de la noticia, el periódico de los Mitre explicita, al citar las fuentes, que lo que denominan "campo" está conformado por las instituciones que conforman la Mesa de Enlace. La bajada, por su parte, brinda elementos para comprender de qué se trata la noticia y brinda información negativa sobre el Gobierno de Cristina Kirchner: "La Mesa de Enlace respondió las acusaciones del Gobierno y señaló la falta de previsibilidad".

El discurso reproduce los descargos de la Mesa de Enlace; a través de la palabra del presidente de la Sociedad Rural Argentina, Luis Miguel Etchevehere; del entonces titular de Coninagro, Carlos Garetto y del senador de Unión por Entre Ríos, Alfredo De Angeli, tras las declaraciones del Jefe de Gabinete "que acusó de avaros a los chacareros que no comercializan su producción y de 'amarrocar' porque tienen capacidad de ahorro". Según la clasificación de Lucrecia Escudero se trata de fuentes textuales institucionales oficiales, por tratarse de miembros de instituciones del poder político y social.

Dichas fuentes describen la existencia de un panorama desfavorable para la actividad agropecuaria debido a la situación económica que atraviesa el país y a las medidas implementadas por el Gobierno Nacional:

- 'La Mesa de Enlace rechazó los planteos oficiales, al refutar que no actúa con `avaricia', como sostiene el Gobierno, sino `con prudencia en un mercado donde sus insumos están 
atados a la cotización de un dólar futuro que desconocen, en un escenario de inflación que supera el 30\% anual'. Las entidades afirmaron que 'los productores saben que deben afrontar los gastos de la presente campaña en total incertidumbre sobre los costos de sus insumos, en un escenario de nulo financiamiento y con la responsabilidad de mantener las fuentes de trabajo y de cumplir los compromisos contraídos'”.

- 'Para Luis Miguel Etchevehere, presidente de la Sociedad Rural Argentina: 'Es un acto de responsabilidad de los productores que pueden guardar parte de la cosecha y no venderla toda junta ya que, en un contexto de 30 por ciento de inflación, si vende toda la cosecha de golpe sabe que ese dinero valdrá un 30 por ciento menos y que no podrá afrontar sus gastos futuros. Sería bueno que el Gobierno explique por qué después de haber recibido tanto dinero del campo no le alcanza; y por qué está dilapidando las reservas de todos los argentinos'”.

- "Esta vez los que están pasando la factura al Gobierno no son los empresarios sino la sociedad. Es una lástima que el Gobierno no haya escuchado a tiempo los mensajes de alarma. Ahora intenta buscar un culpable para echarle la culpa. Es hora que asuma su responsabilidad', afirmó Carlos Garetto, presidente de Coninagro”.

- "Entre los que le respondieron al jefe de Gabinete, Jorge Capitanich, se sumó el senador de Unión por Entre Ríos, Alfredo De Angeli, que desmintió que los pequeños y medianos productores guarden la soja para especular. 'Están desfinanciados y endeudados y no pueden aguantar la fuerte carga impositiva que tienen a nivel provincial y nacional. El Gobierno sigue confundiendo a la sociedad porque generalizan, pero en las chacras, yo no veo las silobolsas'”.

Meses más tarde, en octubre de 2014, en un contexto caracterizado por caída de los precios internacionales de la soja, Eduardo Buzzi, por entonces presidente de la Federación Agraria, reconoció que fue un error aconsejar a los productores que retengan la producción: "El productor perdió y hasta podríamos decir que se equivocó. Nos equivocamos en haber retenido granos y no haber vendido cuatro meses atrás. Esto es objetivamente así”, señaló el dirigente revista Veintitrés ${ }^{31}$.

\footnotetext{
${ }^{31}$ Revista Veintitrés, "Especuladores hechos bolsa”, 9 de octubre de 2014.
} 
El discurso emplea además, una expresión popular y una metáfora que aluden a la idea de un conflicto entre lo que denominan "el campo" y el Gobierno: "La poca predisposición que tiene el campo para vender parte de los 4000 millones de dólares de las cosechas de granos se mantiene bajo la mira del Gobierno. Esta vez las declaraciones del jefe de Gabinete, Jorge Capitanich, que acusó de avaros a los chacareros que no comercializan su producción y de 'amarrocar' porque tienen capacidad de ahorro, encendió nuevamente la mecha del enfrentamiento".

La noticia está acompañada de un espacio titulado "Estrategias para defenderse de la inflación" en donde aparecen destacados en letras de tamaño mayor al utilizado en la noticia y en estilo negrita que contienen las declaraciones de 1) Luis M. Etchevehere, 2) Carlos Garetto y 3) Pedro Apaolaza, vicepresidente de la CRA:

1) “Con 30\% de inflación, el que vende la cosecha de un golpe no podrá afrontar sus gastos futuros".

2) "No respondemos al Gobierno sino a la sociedad: el campo invierte gracias a que programa la venta".

3) "Éste es un país libre, así que vamos a vender cuando creamos que es oportuno hacerlo". El diario La Nación utiliza destacados para resaltar información que considera relevante. En este caso las declaraciones de dirigentes rurales que justifican porqué guardan la producción en silobolsas. Téngase en cuenta, que según van Dijk, las variaciones gráficas son tomadas como elementos fundamentales en la expresión de la ideología de los medios. 


\title{
II.3. La política económica del Gobierno Nacional.
}

\author{
"Muchas veces he dicho que nuestro problema agrario es un \\ problema de envase. Por ahi es por donde es más urgente \\ nuestra metalurgia. Porque con envase e industrialización, \\ toda la estructura agraria del país se modifica (...) \\ Nuestros cereales también pueden salir elaborados, \\ si no en todo en parte, como los aceites vegetales (...) \\ El envase es esencial para la industrialización \\ de nuestra producción rural". \\ Arturo Jauretche (2010: 122).
}

UA 20. La noticia seleccionada se encuentra en la página 14 del rubro Economía, en la edición del 28 de febrero de 2013 del diario La Nación. A diferencia de la noticia "Compromiso de los sojeros" (UA 13), donde el diario Página 12 le dedicaba el 60\% del espacio de la página 6; este discurso ocupa sólo el $25 \%$ de la página, se ubica debajo de la línea de indicatividad y no presenta fotografía. Lo cual indica la escasa jerarquización del acontecimiento.

El título, de carácter informativo, resalta: "Los exportadores le darían a Moreno US\$ 1600 millones". Mientras que la bajada aporta datos contextuales que ayudan a la comprensión del hecho: "El secretario recibió a los grandes operadores y pidió que compren la soja que tienen sin vender los productores".

El discurso trata sobre una reunión entre las empresas que comercializan el $90 \%$ de la soja y el entonces secretario de Comercio Interior, Guillermo Moreno. Oportunidad en la que el funcionario les solicitó que, "que apuren la compra de la oleaginosa que aún está en manos de los productores y que las fábricas con mercadería en su poder la vendan”.

A diferencia del discurso de Página 12 sobre el mismo hecho, el diario La Nación resalta que Moreno tuvo un buen trato con los empresarios. Para ello, emplea citas directas e indirectas de fuentes textuales oficiosas activas, que presentan un grado de identificación que las inscribe en un sector específico. Esto puede deberse a que el periódico intenta preservar la identidad de quien brindó información o a que pretende "poner en boca de alguien" lo que editorialmente supone:

- "Según confiaron fuentes empresarias, Moreno se mostró tranquilo y tomó como 'una reunión de análisis' el encuentro con los exportadores. No obstante, sutilmente solicitó que se aceleraran las compras y ventas de soja”. 
- "Lo pidió, pero no como una imposición. Fue como una especie de reflexión en el marco del análisis de la cosecha', dijo un empresario. Y agregó que Moreno habría expresado la siguiente sugerencia sobre la harina de soja en poder de las fábricas: 'Muchachos, esto que queda hay que venderlo'”.

- 'Otro de los concurrentes destacó el costado cordial que habría mostrado el funcionario. 'Más de uno se sorprendió porque no sabíamos con qué iba a salir. Pero él nos dijo que necesitaba de primera mano conocer cómo estaba la comercialización, y allí se hizo un análisis', contó”.

Todas estas declaraciones son utilizadas para rectificar lo que el mismo diario señaló en su edición del día anterior (27-02-2013), cuando "fuentes del sector" habían adelantado que en la reunión, "el funcionario redoblaría la presión sobre los operadores para que liquiden las divisas". "Los exportadores que asistieron al encuentro, cuya convocatoria sorpresiva fue anticipada ayer por LA NACION, lo hicieron presumiendo que Moreno iba a descargar una fuerte presión para que liquidaran más divisas o que, a cambio de un mayor ingreso de dinero con el pago por adelantado por retenciones, extendiera los plazos para concretar los embarques", se excusa el periódico en su edición del 28 de febrero, luego de haber pronosticado un panorama sombrío para los grandes operadores.

El discurso también emplea fuentes textuales institucionales oficiales, para lograr un efecto de veracidad:

- "Precisamente, Alberto Rodríguez, presidente de la Cámara de la Industria Aceitera y el Centro de Exportadores de Cereales (Ciara-CEC), señaló a LA NACION: 'El tema fue hacer un análisis sobre cómo se estaba realizando la comercialización 2011/2012 y las perspectivas de la 2012/2013, particularmente de soja. Él (por Moreno) quería saber cómo estaba la comercialización y qué esperábamos nosotros'”.

- "Ante la agencia oficial Télam, luego Rodríguez vaticinó que vendidas esas producciones ‘ingresarán al país unos mil seiscientos millones de dólares'".

Finalmente, cabe destacar que según evalúa La Nación, los productores sojeros no comercializan toda la soja porque la utilizan como un ahorro: "suelen retener (la mercadería) para más adelante para hacer frente a inversiones como la siembra de trigo y otros gastos relacionados con su actividad". 
UA 21. "Súper rindes en lotes de soja: de eso no se habla", resalta el diario La Nación en un titular del suplemento "Campo", publicado el sábado 4 de mayo de 2013. La nota se ubica en la página 2 y ocupa el 30\% de su espacio, sobre la línea de indicatividad. La disposición y superficie empleadas la convierten en la principal noticia de la página.

Como puede observarse, no se trata de un título informativo que anuncie un acontecimiento, sino que más bien se enuncia una situación. Como señala Verón, en este caso no se tematiza la situación, sino que se la da por sabida y se alude a ella a través de alguna expresión que tenga relación. Para comprender el título, el lector debe avanzar en la lectura de la noticia y llegar al tercer párrafo, en donde se explica que los productores evitan hablar de los buenos rindes de la cosecha por miedo a "sufrir alguna persecución de la AFIP".

El primer párrafo del discurso compara de manera irónica lo que califica negativamente como la "balbuceante defensa" del entonces ministro de Economía, Lorenzino, con el voto "No positivo" del ex vicepresidente de la Nación, Julio Cobos. El evaluativo axiológico "balbuceante" refleja la postura en contra del enunciador: "Después de la especie de voto No positivo que terminó realizando el ministro de Economía, Hernán Lorenzino, en su balbuceante defensa de las cifras del Indec ante las cámaras de la televisión griega, valen hasta los índices más heterodoxos para saber lo que realmente pasa en la economía". En este fragmento también se señala de manera implícita que se desconoce lo que realmente pasa en la economía del país.

Teniendo en cuenta las estructuras del discurso, esta UA emplea de manera reiterada las figuras retóricas de la comparación, la ironía y la metáfora, para enfatizar información negativa sobre el Gobierno Nacional y categorizar como "víctimas" a los productores. Por ejemplo, compara de manera irónica la situación de los productores con la del organismo encargado de estadísticas y censos nacionales: “Tengo un lote que me rindió 64 quintales por hectárea, pero no lo comentes. Si hay que mencionarlo poné que se lograron 50 quintales', recomendaba un productor en un intento por generar su propio Indec privado, 'truchando' a la baja sus propios rindes de excepción". En este caso, tanto el instituto nacional como los productores son descalificados y se los relaciona con el término coloquial "trucho", que significa falso.

En otra ocasión se emplea la figura retórica de la metáfora para comparar al Gobierno con un toro que puede embestir con nuevas retenciones a los productores que posean buenos rindes: "Lo cierto es que hay un ambiente de temor generalizado a sacar la cabeza ya sea por sufrir alguna 
persecución de la AFIP, por la inseguridad privada o por mostrarle la muleta del torero al Gobierno como para que embista con nuevas retenciones".

Utiliza además, la figura retórica de la hipérbole para exagerar y enfatizar en la sequía registrada en el norte argentino por esos tiempos: "En la única región donde no funciona este fenómeno de ocultamiento de rindes de excepción es en el norte del país incendiado por una seca de dos campañas que no dejó cultivo en pie".

Por otra parte, se emplean expresiones del campo popular en complicidad con el lector que sabe a lo que se refieren: "Pero de las sojas de 60 quintales y aún más, que se lograron con bastante frecuencia en la región de Marcos Juárez, Córdoba, ni pío. La tendencia a silbar bajito y no andar haciendo alardeo alguno es tan fuerte que no ha dejado en los bares ni a los fanfarrones de siempre".

En el discurso se justifica que la "actitud reticente de los productores" se debe a "la inflación y la incertidumbre que provoca una brecha entre el dólar oficial y el marginal que ya superó el 70\%”. Y, a partir de esta explicación, los productores son tratados y calificados de manera explícita como víctimas del modelo económico del Gobierno Nacional:

- "Los chacareros saben que vienen perdiendo poder de compra año a año".

- 'La primera víctima de este ambiente donde nadie quiere ser destacado es la producción. Se encuentra afectado el mismísimo espíritu del que produce, que tiene que lidiar ya no con un Estado convertido en el 'socio bobo', como lo suele describir el dirigente Néstor Roulet al mencionar que con las retenciones sólo comparte las ganancias, sino con un Estado policial".

En este último ejemplo, también se señala de manera implícita que el Estado persigue y reprime a los productores a través de diferentes medidas.

En otro orden de cosas, el discurso se vale de fuentes textuales institucionales oficiales, para reforzar la idea de que los productores se encuentran "afectados" y para alertar sobre un posible panorama de competitividad negativo debido a que el Gobierno no realiza negociaciones bilaterales que favorezcan la exportación de la cosecha:

- “Según un trabajo de Juan Manuel Garzón, economista jefe de la Fundación Mediterránea, la soja puede comprar un 12,2\% menos que el año pasado en términos de bienes de construcción y un $11,8 \%$ en relación a bienes de consumo". 
- "La presentación que realizó el ex secretario de Agricultura, Marcelo Regúnaga, en la jornada organizada por la Fundación Producir Conservando, dejó en claro los costos que se pagan por la ausencia de negociaciones agrícolas para acceder a mercados relevantes de nuestra oferta exportable. 'Con la excepción de Brasil, nuestros competidores están trabajando con nuestros principales mercados en una agenda de negociaciones que pueden afectar nuestra la competitividad en la próxima década', alerta Regúnaga”.

En los párrafos finales, el enunciador explicita su postura desfavorable hacia las políticas económicas del Gobierno, a través de evaluativos axiológicos:

- "Si aislarse y silbar bajito no es bueno para los productores, tampoco lo es para el país".

- "A la ya larga lista de dificultades para exportar se debería agregar la ausencia de negociaciones agrícolas".

Teniendo en cuenta las predicaciones de los diferentes actores del discurso, la AFIP está asociada a la palabra "persecución"; el Gobierno al verbo "embestir" y el Indec está ligado al término "trucho". Léxicos negativos que reflejan la posición del enunciador respecto al tema.

UA 22. El 22 de enero de 2014, el dólar oficial llegó a \$ 7,75; un día antes se cotizaba a \$ 6,17. En este contexto caracterizado por la devaluación de la moneda oficial en un $12 \%$, el diario La Nación tituló, "Los dólares del campo quedaron en la mira oficial" en una noticia publicada el 25 de enero de 2014. La misma se encuentra en el seudorrubro "La crisis cambiaria/ El impacto en la economía real"; creado por el periódico en función de la devaluación para ubicar noticias relacionadas con el tema. Este apartado, utilizado por el diario para ordenar los acontecimientos del día se ubica a su vez en el rubro "Política económica". Cabe destacar que el matutino nacional categoriza de manera negativa la situación monetaria al calificarla como una "crisis". El título utiliza la expresión de uso popular "en la mira" para señalar que los dólares provenientes de las exportaciones agropecuarias son el blanco u objeto al que apunta el Gobierno Nacional que aparece mencionado de manera implícita a través de la expresión "oficial". Mientras que la bajada otorga cifras que ayudan a la comprensión del título: "En los últimos meses dejaron de ingresar US\$ 4000 millones por granos que todavía están en manos del sector productivo". 
En este discurso, el diario La Nación reconoce que los productores tienen "retenidos" 4000 millones de dólares por la cosecha de trigo, maíz y soja pero justifica que "la poca predisposición" de los ruralistas para vender los granos se debe a varios motivos: "por la devaluación acelerada del dólar oficial, por las trabas a la comercialización del trigo y del maíz, un permanente reclamo de la Mesa de Enlace, y por la actual incertidumbre económica".

A lo largo de la noticia, se justifica que los productores "retienen" la cosecha debido a la política económica del Gobierno Nacional que "prefirió perjudicar al campo" poniendo "trabas" a la comercialización de sus productos, en vez de tenerlo como "el mejor aliado". Teniendo en cuenta el cuadrado ideológico de van Dijk, el periódico expresa información negativa sobre el Gobierno, al que califican como "el gran responsable" de la actitud de los ruralistas:

- "Pero vale la pena detenerse en lo que ocurrió en cada uno de estos cultivos para entender que el gran responsable del comportamiento que tienen los productores, que funcionan con la lógica de un agente económico, es el mismo Gobierno. Que en lugar de ser un beneficiario directo del ingreso de dólares en el país prefirió primero perjudicar al campo y después terminar perjudicándose".

En la noticia se señala de manera implícita que las políticas del Gobierno, a través de las "trabas" a la comercialización del trigo y el maíz, causaron la falta de dólares que "provocó un tembladeral económico". Para sustentar esta evaluación utiliza la palabra autorizada de Gustavo López, director de Agritend: "Según Gustavo López, los 4000 millones de dólares en granos que se tienen retenidos se explican por los 600 millones que todavía no se vendieron de trigo, los 1000 millones de maíz y los 2400 millones de soja de la vieja y nueva cosecha”.

Por otra parte, para reforzar la idea que el Gobierno terminó perjudicándose con sus decisiones económicas utilizan las metáforas de "tirar un tiro en el pie" y "apuntar al otro pie para pegarse el tiro":

- "En el caso del trigo, el Gobierno se acaba de tirar un tiro en el pie con el anuncio del ministro de Economía, Axel Kicillof, que en lugar de liberar 1,5 millones de toneladas en forma inmediata (...) liberó sólo 500.000 toneladas. La consecuencia fue que, en lugar de tener vendido más del $50 \%$ de la cosecha de trigo, se tiene comercializada sólo el $25 \%$. Una diferencia de 600 millones de dólares". 
- "Con el maíz, el Gobierno le apuntó al otro pie para pegarse el tiro. Sin anuncios de ningún tipo en cuanto a cupos de exportación, ni señales de cambios en el proceso de otorgamiento de ROE's (registro de operaciones al exterior) el desaliento de los productores se expresó en que tienen vendidas al momento sólo 1,7 millones de toneladas contra los 8 millones de toneladas que, según Gustavo López, hubieran sido vendidas de acuerdo con la comercialización de las últimas campañas. Otros 1000 millones que no ingresaron".

En cuanto a la polifonía de voces, el periódico también emplea la palabra autorizada de Ernesto Ambrosetti, economista de la Sociedad Rural Argentina quien evalúa que "hasta que no se estabilicen los precios relativos, es muy difícil que los productores se larguen a vender sus granos. 'La devaluación nominal no mejora por sí sola la competitividad del agro. Se necesita un plan integral para controlar la inflación, generar confianza y que se reacomoden los precios relativos hasta estabilizarse', afirmó Ambrosetti”.

Como puede observarse el diario plantea, a través de la voz de un referente de la SRA que la devaluación del dólar oficial no resulta beneficiosa para los chacareros que exportan su producción. Esta idea es reforzada en un destacado de la noticia que tiene como título, "Inquietud por los insumos" en donde se advierte que la devaluación perjudica a los productores que deben importar insumos: "La devaluación del dólar oficial también provoca preocupación entre los productores por el posible desabastecimiento de algunos insumos estratégicos que se importan, como algunos herbicidas, fertilizantes o repuestos de la maquinaria agrícola, ya que se perdieron los precios de referencia".

Por otra parte, la noticia se encuentra acompañada por una fotografía, clasificada como documental, que ilustra a una máquina guardando granos de soja en un silobolsa; cuyo epígrafe destaca: "Quedan 10 millones de toneladas de soja sin vender".

UA 23. El 31 de enero de 2014, la moneda local cerró a 8,01 pesos en el mercado mayorista, con lo que registró una devaluación de $18,63 \%$ en dicho mes. El mismo día, Página 12 ocupó alrededor del $70 \%$ de su portada con una noticia en la que su principal fuente, el ministro de Agricultura, Carlos Casamiquela advierte que, "Los responsables son los grandes". 
El título se encuentra en letras mayúsculas, en formato negrita y cursiva; en un tamaño que sobresale respecto a los demás titulares que aparecen y en color blanco sobre un fondo negro; todo esto a fin de atraer la mirada del lector desde el momento en que posa su vista en el diario. Cabe destacar que el periódico utiliza la palabra autorizada y en cita directa del funcionario nacional para titular la noticia más importante de tapa y de la edición. Y si bien no resulta del todo informativo, destaca la idea central de la noticia: que para el Gobierno los grandes productores y exportadores agropecuarios tienen retenida la cosecha. La bajada aporta datos y cifras para la compresión del acontecimiento en la portada: "El ministro de Agricultura, Carlos Casamiquela, le dijo a Página 12 que calcula que 'hay ocho millones de toneladas de granos sin liquidar' y que 'los pequeños y medianos productores no tienen espalda financiera para hacerlo'. Están en juego 3500 millones de dólares”.

Una extensa fotografía en la que aparece el titular de la cartera agropecuaria ocupa el 60\% del espacio total de la portada. Conforme a la clasificación realizada por Verón, corresponde a la retórica de las pasiones, al retratar a un personaje marcado por su notoriedad política. En la fotografía se muestra la expresión de la cara del personaje que se encuentra concentrado en lo que dice y sus manos abiertas como explicando algo.

La noticia ocupa alrededor del $50 \%$ de las páginas 2 y 3 , que se encuentran diagramadas a modo de falsa central. Ubicado en el rubro Economía y emplazado en las dos páginas más importantes de la edición, es sin dudas "el" acontecimiento de la jornada.

El título, "Hay ocho millones de toneladas sin liquidar", que vuelve a citar de manera directa la palabra de Casamiquela, se encuentra desplegado a "modo bandera", ocupando todo el ancho de la página 3 y un fragmento de la 2. Por su parte, la volanta y la bajada destacan información negativa sobre los exportadores, que según el ministro: retienen en silobolsas "granos exportables por 3500 millones de dólares", "presionaron" por la devaluación y "Ahora, con el nuevo dólar, siguen presionando".

En esta unidad de análisis, Página 12 reconoce la existencia de un campo que posee diferentes estratos y realidades: pequeños, medianos y grandes productores; a diferencia del diario La Nación que como hemos visto en las unidades de análisis 14 y 19 y como se observará en la UA29, plantea la existencia de un campo homogéneo. 
- "Página/12 habló con varios productores sojeros, pequeños, y les consultó si estaban dispuestos a vender soja con el actual tipo de cambio. La respuesta fue que ellos no tenían los granos, sino que ya habían sido vendidos a los exportadores”.

- "Los pequeños y medianos productores no tienen capacidad de mantener en silos y silobolsas su producción. Generalmente venden cuando van sacando cosecha. Quien tiene stock de soja cuenta con una espalda financiera importante" (Casamiquela).

Por otra parte, el discurso devela que para la Mesa de Enlace el Estado se queda con la ganancia de la cosecha de soja pero omiten mencionar la existencia de los grandes exportadores: "En el conflicto por la Resolución 125, los dirigentes de la Mesa de Enlace explicaban que con el nivel de retenciones que se pretendía aplicar, la ganancia del productor quedaría en prácticamente cero. $\mathrm{Su}$ argumento era que con los derechos de exportación móviles el Estado se quedaría con casi todo el valor de la cosecha de soja. Dentro de esa ecuación, en ningún momento aparecían los grandes exportadores. Ahora ocurre lo mismo".

Por otra parte, el discurso hace referencia a la concentración de la producción y exportación de granos en el país, algo que no es mencionado en las unidades de análisis del diario La Nación: "Si bien la producción primaria de granos supera las 100 millones de toneladas, con 73.000 productores distribuidos en todo el país, sólo el 6 por ciento concentra el 54 por ciento de la producción. En el caso de la soja, un poco más de la mitad de la totalidad de la cosecha es exportada por Cargill, Noble Grain, ADM, Nidera y Bunge. Las diez primeras cerealeras del país explican el 96 por ciento de las ventas al exterior”.

La fotografía que acompaña la noticia en la página 3 retrata un primer plano del rostro de Casamiquela mientras otorga la entrevista a Página 12. También se trata de una imagen que corresponde a la retórica de las pasiones, según la clasificación de Verón, debido a fue "arrancada" al personaje que "ha sido sorprendido cuando su rostro expresaba un estado de espíritu o una emoción" (1985).

Página 12 emplea fuentes textuales institucionales oficiales, según la clasificación de Lucrecia Escudero. La principal corresponde, como ya señalamos al ministro Casamiquela, referente de un sector del poder político. La palabra ajena es introducida a través de citas directas e indirectas, en función de la persona que habla, ya que su voz está autorizada. El discurso es construido como 
noticia y no en forma de entrevista porque de esta forma es posible agregar la palabra de otros actores con orientación divergente a las declaraciones del funcionario nacional.

Teniendo en cuenta el cuadrado ideológico propuesto por van Dijk, el titular de la cartera agropecuaria otorga información negativa sobre los exportadores, a quienes acusa de reclamar una devaluación, especular, presionar al Gobierno y querer erosionarlo:

- "Hace tres meses, los exportadores, a través de la Mesa de Enlace, reclamaban una devaluación. Y ahora con el nuevo tipo de cambio siguen presionando. Según nuestros cálculos, hay 8 millones de toneladas de granos, mayormente soja, sin liquidar. Esto equivale a 3500 millones de dólares que podrían ingresar al país”. Este fragmento con declaraciones del funcionario nacional indica de manera implícita, la connivencia entre la Mesa de Enlace y los grandes exportadores.

- "El ministro de Agricultura, Carlos Casamiquela, cuestionó en diálogo con Página/12 a la dirigencia agropecuaria y a los exportadores por llevar adelante una estrategia de especulación, al no vender su producción, con el objetivo de erosionar al gobierno nacional".

- "Uno presupone que la decisión de no vender soja se había tomado con un dólar en torno de los cinco pesos. Hoy la situación es totalmente diferente. Después de esta devaluación, vemos una estabilidad manifiesta del tipo de cambio, lo que presupone que deberían vender", agregó el funcionario.

El discurso también reproduce, a través de una cita directa, la palabra de Carlos Garetto, por entonces presidente de la Confederación Intercooperativa Agropecuaria (Coninagro), para luego polemizar y dar un ejemplo concreto de la connivencia entre la Mesa de Enlace y los exportadores: “'No creo que esto (por el dólar a 8 pesos) sea un incentivo a liquidar, más cuando hay un proceso inflacionario en pesos. Hoy no sabemos el tipo de cambio, no sabemos en dónde se va a parar y por ahora no se va a liquidar', manifestó Carlos Garetto, titular de Coninagro. (...) Entonces, cuando los dirigentes de la Mesa de Enlace explicitan que 'no hay incentivos para liquidar la cosecha retenida', no estarían reclamando por la rentabilidad de los pequeños productores como declaman, sino que hablarían en nombre de los grandes exportadores. Esta es la visión que prima en distintas áreas del Poder Ejecutivo”. 
Y, por otra parte, reproduce la palabra de la Corriente Agraria Nacional y Popular (Canpo)organización identificada con los objetivos del Gobierno Nacional- que propone un nuevo sistema de comercio exterior: "El eje central de la política de comercialización debe ser la regulación estatal del comercio exterior, con la creación de una Agencia Nacional de Comercialización que garantice a los pequeños y medianos productores el real valor de su producción".

UA 24. La noticia titulada 'Capitanich acusó a productores de `amarrocar' la cosecha y dijo que se busca desestabilizar" fue publicada en el diario La Nación en su edición del 1 de febrero de 2014. Se trata del discurso más importante de la página 12, por ocupar alrededor del 35\% de su espacio y estar ubicada sobre la "línea de indicatividad". Otro factor que indica la jerarquización del acontecimiento es el tamaño de las letras del título, que sobresalen respecto a los demás.

Cabe destacar que la noticia se encuentra ubicada en el seudorrubro "La crisis cambiaria / Reservas y precios, dos frentes abiertos"; creada por la centenaria publicación luego de la devaluación de enero de 2014 para clasificar información referida al tema. La primera parte del seudorrubro, que evalúa de manera negativa la situación económica del país, es utilizada también para clasificar las UA 19, 20, 22, 24, 25 y 26.

El título resalta las declaraciones del ex jefe de Gabinete de Ministros, Jorge Capitanich, sobre los granos almacenados en silos y silobolsas. En este sentido, reproduce la expresión "amarrocar", perteneciente al dialecto lunfardo que significa juntar dinero u objetos de valor con avaricia y utiliza comillas, para distanciarse de la palabra ajena.

La Nación publica esta información dos días antes de realizarse una reunión entre referentes de las cámaras que nuclean a las firmas comercializadoras y exportadoras con representantes del Gobierno, con el objetivo de negociar la liquidación de la soja acopiada.

La aparición de esta noticia, en la antesala del mencionado encuentro, conlleva a pensar que el medio podría estar advirtiendo a las empresas cerealeras, el clima en el que se desarrollaría la reunión, teniendo en cuenta que el Gobierno evalúa de manera negativa la acción de almacenar granos.

La Nación utiliza como fuente textual institucional oficial la palabra de Capitanich para luego polemizar y contrastarla con las declaraciones de referentes del sector rural que aparecen en la 
noticia titulada, "Para el campo no hay avaricia en la venta de granos, sino prudencia". Esta última se encuentra en la misma página del periódico; a la derecha del discurso seleccionado y fue analizada en la UA 19.

El enunciador utiliza citas directas para trasladar la responsabilidad de lo que se dice al "otro" y citas indirectas que van enlazando la palabra propia y la ajena. Esto le permite realizar evaluaciones negativas sobre la situación del Gobierno de Cristina Fernández de Kirchner a quien adjetiva con los evaluativos axiológicos: "preocupado" y viviendo un "malestar" debido al faltante de reservas. De igual modo, evalúa que Capitanich "endureció" su discurso destinado a los productores rurales:

- "Preocupado por el drenaje de reservas del Banco Central, el Gobierno endureció su discurso hacia los productores agropecuarios, a los que acusó de 'amarrocar' cosechas, y volvió a insistir en que hay intentos de 'desestabilización' que conjugan 'exponentes' políticos, sindicales y económicos".

- "En la línea trazada por la presidenta Cristina Kirchner, el jefe de Gabinete, Jorge Capitanich, fue más duro de lo habitual ayer en su conferencia de prensa matinal. El malestar de la Casa Rosada por lo que consideran una jugada especulativa de los exportadores de granos fue expuesto sin medias tintas: fue lo primero que resaltó el ministro coordinador, antes de avanzar en un repaso de otros temas y de que se abriera la minirronda de tres preguntas de los periodistas". En este fragmento también puede observarse el uso de la expresión popular "sin medias tintas" que significa decirlo todo sin reserva. Por otra parte, utiliza un adjetivo evaluativo no axiológico para calificar de manera negativa las conferencias de prensa del ex jefe de Ministros, a través del diminutivo "mini”".

En cuanto a la lexicalización o palabras utilizadas para expresar un concepto, el medio señala de manera explícita la existencia de un "conflicto" entre el Gobierno y quienes guardan la cosecha: "Para tratar de zanjar el conflicto, el funcionario convocó a un encuentro, pasado mañana, a las cámaras que nuclean a las firmas comercializadoras y exportadoras".

El diario también reproduce las declaraciones de Capitanich en las que identifica al sector rural que guarda la cosecha: "Si bien diferenció entre los pequeños y grandes productores, Capitanich aseguró que están las condiciones dadas para vender las cosechas. 'Existen ciertas conductas que 
tienen que ver con la avaricia u otro tipo de carácter especulativo', argumentó. Según dijo, se trata de empresarios con capacidad de ahorro, lo que los habilita a acumular en silos bolsas sin necesidad de liquidar para encarar la siembra siguiente".

Otras fuentes textuales institucionales oficiales utilizadas son los referentes de los poderes Ejecutivo y Legislativo, Axel Kicillof y Julían Domínguez:

- "El Ministerio de Economía, comandado por Axel Kicillof, sostiene que hay por lo menos 8 millones de toneladas de soja sin exportar, lo que equivaldría a 4000 millones de dólares".

- “También el ex ministro de Agricultura y actual presidente de la Cámara de Diputados, Julián Domínguez, reflotó una vieja iniciativa. 'Tenemos que impulsar una agencia nacional de comercialización de cooperativas de productores. No puede quedar en manos de las diez empresas que manejan el comercio exterior de granos', dijo, en su paso por Villa María, Córdoba". Nótese que el diario utiliza el evaluativo no axiológico "vieja" para descalificar el proyecto oficial.

En el discurso aparece además, una fuente oficiosa activa que presenta un grado de identificación aceptable que la inscribe en un universo referencial específico. Según Escudero, "el recurso de estas fuentes textuales vuelve muy difícil la verificación de la información suministrada, pero al mismo tiempo arroja sobre la escena informativa datos y personajes con el objetivo de hacerlos circular" (1996:110): "Según dijeron fuentes oficiales a LA NACION, la idea es sostener el dólar a $\$ 8$, con lo cual existe un escenario de 'previsibilidad' en la política cambiaria y aseguran que está descartada de plano una devaluación mayor”.

La nota también hace referencia a un encuentro entre Capitanich y el empresario cárnico Alberto Samid y utiliza una imagen de la reunión para ilustrar la nota a fin de documentar el hecho.

Finalmente, utiliza como fuente la cuenta que posee Luis D'Elía en la red social Twitter, a quien el diario La Nación califica de manera negativa y despectiva: "El piquetero oficialista Luis D'Elía pidió desde Twitter aplicar la ley de abastecimiento para incautar granos acopiados por productores. 'Sembró a \$ 5 y quiere cosechar a \$14, a costillas de toda la comunidad argentina', disparó desde su cuenta. También responsabilizó a los productores por la devaluación de la moneda". 
UA 25. En la noticia titulada "Capitanich les pedirá a las cerealeras que liquiden más dólares", el diario La Nación anunció, el 3 de febrero de 2014, la reunión que ese mismo día llevaría el ex jefe de Gabinete de Ministros, Jorge Capitanich, con empresarios del sector. El discurso se ubica en el rubro Política, el más importante de la publicación, seguido de Economía y ocupa alrededor del $15 \%$ de la página 5 .

El diario de los Mitre utiliza además, el seudorrubro "La crisis cambiaria| Estrategia de la Casa Rosada"; sistema de organización creado por el medio después de la devaluación del peso oficial en enero de 2014, para ubicar noticias relacionadas con dicho tema. El mismo seudorrubro acompaña a las UA 19, 22, 24 y 26. Cabe señalar, que el matutino tamaño sábana evalúa de manera negativa la situación económica del país, al indicar la existencia de una "crisis".

El diario La Nación utiliza un lenguaje informal, ligado a la literatura, para descalificar al Gobierno Nacional, en su nuevo intento por solicitar que las empresas exportadoras liquiden la producción. Recordemos que cuando Guillermo Moreno ocupaba el cargo de secretario de Comercio se realizó una reunión de similares características con empresas del sector cerealero, como pudo observarse en las UA 12 y 20: "El Gobierno volverá a desplegar hoy una de sus jugadas más repetidas en medio de la tormenta cambiaria. A media mañana, el jefe de Gabinete, Jorge Capitanich, se verá con los representantes de las principales compañías cerealeras del país. Buscará saber, de acuerdo con la terminología que utiliza el Gobierno, cuánto stock tienen en 'silobolsas'. También les pedirá que apuren la exportación de lo almacenado para ingresar dólares al país y contener, de esa manera, la crónica pérdida de reservas del Banco Central. Es lo mismo que reclamó en los últimos días a través de discursos en público”.

En el fragmento anterior puede observarse además, la utilización de una metáfora para describir en términos negativos la situación económica del país, al señalar la existencia de una "tormenta cambiaria".

El diario adelanta que en la reunión podrían participar también el ministro de Economía, Axel Kicillof y el presidente del Banco Central, Juan Carlos Fábrega; a quienes categoriza de manera irónica como "viejos conocidos para las cerealeras", debido a los reiterados encuentros mantenidos por el mismo tema. 
La Nación plantea además, la existencia de un conflicto entre el Gobierno y el sector cerealero y teniendo en cuenta el cuadrado ideológico de van Dijk, brinda información negativa sobre el primero y positiva sobre el segundo:

- "A fines del año pasado, las empresas acordaron con los tres funcionarios realizar exportaciones y comprar una letra del Banco Central por más de 1800 millones de dólares. Pese al guiño de las compañías, el Gobierno volvió a la carga en los últimos días contra el sector. Capitanich acusó el viernes a los grandes productores agrícolas de 'amarrocar' sus stocks de soja por 'avaricia', algo que demoraba la liquidación de divisas".

En cuanto a las predicaciones, el periódico evalúa de manera negativa que "la reunión se realizará en medio de un clima enrarecido debido a las últimas críticas oficiales hacia el sector". Lo cual conlleva a pensar que La Nación podría estar advirtiendo a los referentes del sector cerealero en qué términos se desarrollaría la reunión.

En lo referente a la lexicalización, en este discurso la cosecha sin liquidar se denomina "granos que no se vendieron hasta el momento" y "granos almacenados". A diferencia del diario Página 12 que emplea la expresión "cosecha retenida", que posee connotaciones negativas.

La Nación utiliza como fuente textual institucional oficial las palabras de 1) Jorge Capitanich para brindar datos sobre la cantidad de dinero que se estimaba liquidar con la venta de la cosecha y 2) del especialista Gustavo López, que actúa como voz autorizada para brindar detalles sobre los granos que aún no se habían vendido:

1) "Según el jefe de Gabinete, hay 'proyecciones en materia de liquidaciones de exportaciones de cereales equivalentes a entre 27.000 y 30.000 millones de dólares, entre stock no liquidado y a liquidar, producto de la nueva cosecha y también con la venta de otros bienes que se exportan'. También destacó que 'la meta alcanza para este año a los 94.000 millones de dólares'”.

2) “Como ya informó LA NACION, al país habrían ingresado 4000 millones de dólares por granos que no se vendieron hasta el momento, según un cálculo que hizo el consultor del mercado granario Gustavo López, director de Agritend. Se explican por los 600 millones que todavía no se vendieron de trigo, los 1000 millones de maíz y los 2400 millones de soja de la vieja y la nueva cosecha”. 
En el discurso también le otorga la palabra, a través de una cita indirecta, a Ernesto Ambrosetti, economista de la Sociedad Rural, quien brinda información negativa sobre el Gobierno al señalar que mantiene una deuda con los exportadores: "Señaló, sin embargo, que el Gobierno les debe a los exportadores los derechos de exportación por dos millones de toneladas de trigo que fueron adelantadas en la campaña anterior y que más tarde el entonces secretario de Comercio Interior, Guillermo Moreno, no permitió exportar. Y aclaró que las liquidaciones de divisas de los exportadores son normales".

Y, finalmente, en el discurso aparecen fuentes oficiosas activas a las que denomina "fuentes del sector privado que pidieron reserva de sus nombres". Las mismas informaron que el encuentro de Capitanich con los referentes del sector agroexportador "fue pactado a mediados de la semana pasada".

UA 26. En la noticia titulada “Cerealeras prometen aportar US\$ 6000 millones más”, el diario La Nación informa sobre el resultado de la reunión llevada a cabo entre el entonces jefe de Gabinete de Ministros, Jorge Capitanich, y representantes de la mesa directiva del Centro de Exportadores de Cereales.

El centenario periódico publica el acontecimiento en su edición del 4 de febrero de 2014, en el rubro "Política" y en el seudorrubro "La crisis cambiaria/ Impacto en el mercado y en los salarios"; creado por el medio después de la devaluación del peso oficial en enero de 2014, para ubicar noticias relacionadas con dicho tema. Como ya señalamos en otras UA, La Nación evalúa de manera negativa la situación económica del país, al indicar la existencia de una crisis.

La noticia, se ubica casi en el centro de la página 6 y ocupa alrededor del $25 \%$ de la misma. La cantidad de espacio asignado al discurso y su posicionamiento en la página indican que se trata de un acontecimiento de escasa relevancia para el periódico; a diferencia de Página 12 que le otorga el $60 \%$ de su tapa y lo ubica en sus páginas 2 y 3 , diagramadas a modo de falsa central (ver UA 27).

Al igual que en el título, la bajada enfatiza información sobre el compromiso del sector cerealero: “Los empresarios le aseguraron al Gobierno que superarán las ventas de 2013”.

El mismo diario, que en su edición del 1 de febrero de 2014 mencionaba un "conflicto" entre el Gobierno y las firmas comercializadoras y exportadoras; en esta ocasión alude al consenso entre 
ambas partes: "El Gobierno y las cerealeras acordaron realizar una nueva reunión esta semana para hablar sobre cuál podría ser la liquidación mensual que los exportadores proyectan para todo el año".

El día anterior, La Nación también había adelantado que la reunión se realizaría "en medio de un clima enrarecido debido a las últimas críticas oficiales hacia el sector" y que el Gobierno les pediría a las cerealeras que "apuren la exportación de lo almacenado". Sin embargo, este discurso baja el tono negativo con el que se había referido días antes a la reunión y señala: "Según pudo reconstruir La Nación, no hubo exigencias del Gobierno a los exportadores para que aporten en lo inmediato algún monto adicional de divisas". Lo cual indica que el periódico especulaba con una reunión áspera que finalmente se llevó a cabo de otro modo.

El discurso predica que el Gobierno se encuentra necesitado de los dólares provenientes de la soja: "Ante la necesidad del Gobierno de que el campo venda lo que aún tiene sin comercializar de la última cosecha de soja, los exportadores les llevaron ayer al jefe de Gabinete, Jorge Capitanich; al ministro de Economía, Axel Kicillof, y al presidente del Banco Central, Juan Carlos Fábrega, una noticia positiva: estimaron ante los funcionarios que este año la agroexportación aportará entre 27.000 y 29.000 millones de dólares, es decir, entre 4000 y 6000 millones más que en 2013”. De igual modo, califica como positivo el hecho de liquidar los granos de soja.

En este discurso aparecen más fuentes oficiosas activas que las habituales, teniendo en cuenta que, como venimos observando en las UA anteriores el diario La Nación utiliza en su mayoría fuentes textuales institucionales oficiales:

- "Como sector, creemos que la comercialización de la cosecha va a ser fluida', señaló una fuente de esa cámara”.

- “Tenemos una perspectiva positiva para el año, para la cosecha y la liquidación de divisas', señaló por su parte una fuente de la cerealera Dreyfus, una de las multinacionales del sector".

- "No obstante, trascendió que los funcionarios se mantuvieron firmes en las medidas económicas ya tomadas con relación al dólar. Fue, según interpretaron operadores, una advertencia de que no habría una nueva devaluación". 
Cabe resaltar que La Nación utiliza datos de la consultora FyO, que estima que la soja sin vender es de 4,6 millones de toneladas que representan un valor de US\$ 2400 millones. A diferencia de Página 12, que en su edición del 31 de enero se basó en las estimaciones del ministro de Agricultura, Carlos Casamiquela, para informar acerca de la existencia de ocho millones de toneladas de granos sin liquidar, una cifra que casi duplica las estimaciones de la consultora. Nótese que La Nación prefiere utilizar datos suministrados por instituciones privadas antes que los aportados por las dependencias oficiales.

Finalmente, el discurso utiliza un evaluativo no axiológico para restar importancia al stock de granos no liquidados: "lo que los productores aún tienen de soja sin vender es ínfimo", ya que representan un 9\% de la cosecha total que "se ubicó en 49,3 millones de toneladas".

UA 27. El 7 de febrero de 2014, la portada de Página 12 pone foco en el compromiso de las cerealeras para liquidar los granos que tenían retenidos en silos y silobolsas. El acontecimiento ocupa el $60 \%$ de la tapa y fue construido con el ingenioso estilo que caracteriza al matutino nacional. "Se abrió la canilla", titula en letras mayúsculas, con estilo cursiva y negrita y a un tamaño superior al propio logo del diario. Sobre el título se ubica un fotomontaje en el que aparece un grifo por el que caen granos de soja. Como puede observarse, la imagen y el título son apelativos; es decir, están volcados hacia quien los percibe y se combinan con el fin de impactar al perceptor. Esta construcción metafórica conlleva a interpretar que la liquidación de granos estaba obstruida o retenida pero ahora puede fluir.

La bajada, más informativa, ayuda a la comprensión del acontecimiento: "Tras una nueva reunión con el Gobierno, finalmente las cerealeras cedieron y se comprometieron a liquidar dos mil millones de dólares en este mes".

El periódico jerarquiza el acontecimiento ubicándolo- dentro del rubro Economía- en sus páginas internas más importantes, la 2 y 3 , diagramadas a modo de falsa central. De igual manera, emplea un titular desplegado a modo bandera y una extensa fotografía que ocupa alrededor del $30 \%$ de la página 3.

En el interior del periódico, el título de la noticia emplea una metáfora para enfatizar que tras una serie de encuentros se comercializará la producción que estaba retenida: "En la tercera reunión, se abrió la silobolsa”. Página 12 señala este enunciado en complicidad con el lector que 
está informado sobre el tema y entiende lo que el periódico quiere expresar. A esta operación que generalmente se utiliza en los titulares de los semanarios, Verón llama efecto de reconocimiento. La volanta agrega cifras y datos contextuales que suman elementos para comprender el acontecimiento y subraya que, "Las cerealeras se comprometieron a liquidar exportaciones por 2000 millones de dólares durante febrero". De igual modo, la bajada agrega que según Capitanich, "los exportadores asumieron el compromiso de liquidar parte de las divisas demoradas".

El discurso trata sobre el compromiso asumido por empresas exportadoras de cereales y oleaginosas para liquidar 2000 millones de dólares durante el mes de febrero, correspondientes al remanente de la cosecha pasada, en el marco de una reunión convocada por autoridades del Gobierno. El periódico evalúa que, "se trata fundamentalmente de soja retenida en silobolsas e instalaciones de acopio en zonas rurales". Teniendo en cuenta los léxicos utilizados en el discurso, el verbo retener implica “caer bajo el poder de alguien",32, por lo que posee connotaciones negativas, a diferencia de otros términos como "guardar" o alojar" empleados en La Nación. En términos bajtianos, podríamos decir que cada periódico utiliza palabras con diferente "acentuación ideológica" para referirse a la producción que no se comercializa y cada uno lo hace en función de la intención que posee.

En cuanto a las fuentes, el diario emplea declaraciones de empresarios en citas indirectas: "Sin embargo, en función de las nuevas condiciones del mercado cambiario (posdevaluación), las principales firmas exportadoras consideraron que está garantizada la liquidación de aquella cifra en el transcurso del mes, por decisión de los productores y porque ellos mismos así le aconsejarían hacer a sus clientes, sostuvieron en estos encuentros".

El periódico también utiliza como fuente la red social Twitter para reproducir las declaraciones que hizo en su cuenta el entonces jefe de Gabinete, Jorge Capitanich, sobre el compromiso de los exportadores: "Indicó allí que la decisión de las cerealeras se había tomado `en base a la estabilidad cambiaria y las proyecciones derivadas del flujo de exportaciones'".

Se utiliza también como fuente textual institucional oficial, la palabra del ministro Carlos Casamiquela, quien había estimado en más de 3500 millones de dólares el valor del producto con destino a exportación que se encontraba retenido. El discurso toma esta cifra como

\footnotetext{
${ }^{32}$ Definición de la Real Academia Española.
} 
verdadera, ya que fue formulada por la voz autorizada del máximo responsable de la cartera productiva, y seguidamente evalúa: "El monto comprometido por los exportadores es significativamente menor, aunque atiende de manera suficiente una necesidad de las cuentas externas para mantener cierto equilibrio en el mercado de divisas $y$ en las reservas internacionales del Banco Central”.

Finalmente, se utiliza la palabra del secretario de Comercio, Augusto Costa, quien desmintió rumores que señalaban que el Gobierno impediría la importación de bienes e insumos para la producción: "Ante los rumores que se han generado en torno de la imposibilidad de acceder a las divisas para la importación de insumos, `el gobierno nacional está dando claras señales de previsibilidad para las variables macroeconómicas, desestimando todas las campañas destinadas a generar incertidumbre'",

Cabe destacar que Página 12 describe al mercado cambiario en términos positivos, como equilibrado o "calmado"; a diferencia de La Nación que señala la existencia de una "tormenta cambiaria" (UA 25, 03/02/2014): "El alivio en el mercado cambiario se vio reflejado en el descenso del dólar en sus distintas versiones. En el mercado mayorista cotizó a 7,88 pesos, el oficial de referencia para bancos y casas de cambio se ubicó en 7,89 pesos para la punta vendedora (dos centavos menos que el miércoles), mientras que las operaciones de contado con liquidación bajó 38 centavos, a 11,62 pesos, y el denominado “dólar Bolsa” se redujo a 10,83. El mercado ilegal o "dólar blue”, casi sin operaciones, informó una caída de 15 centavos, a 12,40”. Por otra parte, el periódico emplea una imagen que documenta o prueba la existencia de la reunión y en su epígrafe señala: "Capitanich, Kicillof y Fábrega recibieron a los dirigentes cerealeros, encabezados por Hugo Kranjc, de Cargill”.

UA 28. El viernes 14 de marzo de 2014, La Nación construye una noticia basada en la palabra del productor y empresario agroindustrial Gustavo Grobocopatel, ingeniero agrónomo que conduce una de las principales compañías agropecuarias del país y que el mismo diario había calificado, en su edición del 2 de diciembre de 2007, como "el ambicioso rey de la soja".

“El próximo gobierno debe mejorar la relación con el campo', dijo Grobocopatel”, titula el diario de los Mitre en la página 16 del rubro "Economía", que a su vez tiene como seudorrubro la insignia: "Expoagro 2014". Esta sección especial fue creada para ubicar noticias relacionadas con 
la muestra agropecuaria a campo abierto que posee como accionistas a los diarios Clarín y La Nación.

Nótese cómo el diario jerarquiza la palabra ajena y titula a través de una cita directa que expresa el deseo de un empresario en defensa de los intereses de un sector particular de la ruralidad ligado a la exportación. Además, la frase indica de manera implícita la existencia de un conflicto entre el Gobierno y el "campo", en tanto sector homogéneo que no posee estratos.

La volanta destaca de manera positiva la figura del entrevistado resaltando que se trata de, "La visión de uno de los principales empresarios". Por su parte, la bajada especifica que el ingeniero se encontraba "de visita en la muestra del sector agropecuario" y agrega que el agricultor opinó que el sector "tiene que seducir al resto de la sociedad para un proyecto inclusivo".

En este discurso, la palabra ajena es introducida para persuadir a los lectores; es decir, como explica van Dijk, para cambiar la mentalidad de los receptores de modo que sean coincidentes con las creencias, intenciones y objetivos del hablante. El centenario matutino reproduce la evaluación de un líder de opinión que hace lobby y se diferencia de la política del Gobierno Nacional de Cristina Kirchner: “El próximo gobierno va a tener que adoptar una política hacia el agro diferente de la actual y tendrá que mejorar la relación con el campo', afirmó Gustavo Grobocopatel, CEO (director ejecutivo, en castellano) del grupo Los Grobo, que ayer recorrió Expoagro. 'El desafío para el sector será seducir al resto de la sociedad para un proyecto inclusivo; la brecha entre ricos y pobres se tiene que reducir por el crecimiento del PBI per cápita y no por nivelar hacia abajo', explicó".

De igual manera, la palabra del "otro" se reproduce en función de la persona que habla, ya que su voz está autorizada al tratarse de un referente con poder e influencias económicas. En una de sus declaraciones, Grobocopatel opina que el empresario argentino "debería integrarse más en los temas que exceden su función, como lo político y lo social". Y, en otra, demuestra su opinión favorable sobre la conformación de multinacionales y la compra de empresas argentinas: "Hace unas semanas, el agro se vio conmovido con el anuncio de la compra del 51\% de Nidera por parte del grupo chino Cofco. 'Es una noticia positiva, forma parte de una tendencia global de grandes grupos de China y Japón que buscan empresas de la Argentina para crecer', explica. 'Nosotros soñamos con ser una empresa global, la Argentina necesita más multinacionales de la alimentación', afirmó". 
Por otra parte, La Nación reproduce declaraciones autorreferenciales del empresario sojero que aluden de manera positiva a sus logros empresariales: "Mi abuelo, cuando empezó en Carlos Casares, hacía de todo: sembraba, cosechaba, iba al banco y arreglaba los alambres; hoy nosotros nos hemos transformado en una empresa que da todos esos servicios a los productores, es una integración radial', explicó”. Y, además, explica su visión o estrategia empresarial: “El asesoramiento es vender know-how (saber cómo o saber hacer); detrás de eso habrá empresas argentinas de maquinaria e insumos que podrán vender sus productos a esos países', dijo".

El acontecimiento construido por La Nación se asemeja a las notas elaboradas en los magazines que algunos autores denominan "revistas del corazón", en donde se muestra la vida de celebridades poderosas del ámbito político, social, económico y de la farándula. Esto puede observarse en las predicaciones que realiza del empresario Grobocopatel: "Su agenda mensual necesita más de 30 días. Hace unas semanas estuvo reunido con el papa Francisco en el Vaticano, como parte de una delegación de católicos, musulmanes y judíos. Antes fue a Albania, donde asesora a los productores de ese país que trabajan en apenas una hectárea. También estuvo en Colombia, con el presidente Juan Manuel Santos, para asesorarlo en la puesta en producción de cuatro millones de hectáreas para soja y maíz. Y al mismo tiempo trabaja en la integración de las compañías que integran Los Grobo, cuya estructura se modificó con la compra de la empresa de agroquímicos Agrofina".

El diario también predica sobre la composición del grupo, aunque no da detalles sobre su capital ni hace referencia a la concentración existente por parte de multinacionales, que operan en el país:

- "Los Grobo creó una fábrica de pastas secas en Chivilcoy y aún mantiene un molino harinero en Brasil"'.

- “Los Grobo vendió el año pasado su compañía en Brasil al grupo japonés Mitsubishi y luego compró la compañía norteamericana de agroquímicos Agrofina”.

- "Respecto de los planes de Los Grobo, el productor cuenta que una de las empresas en las que está asociado, Bioceres, junto con Hugo Sigman, de Insud, está de lleno en la carrera de la bioeconomía. 'Estamos desarrollando plásticos con vegetales y biomasa para producir energía', se entusiasma. Este proyecto lo hacen en el laboratorio de Indear, en Rosario, junto con el Conicet”. 
Por otra parte, la imagen que acompaña la nota corresponde a una foto pose, clasificación realizada por Verón para señalar que el personaje ofrece su imagen al fotógrafo. En ella, aparecen "Paula Marra y (su esposo) Gustavo Grobocopatel, ayer en su local de Expoagro", como explica el epígrafe.

UA 29. "Fuerte deterioro del campo en 10 años: la soja fue la única excepción", tituló en tapa el diario La Nación, el 28 de abril de 2014. La ubicación del titular sobre la línea de indicatividad, el tamaño de sus letras- de mayor extensión comparadas con las demás- y el hecho de ocupar alrededor del 25\% del espacio de la portada demuestran la jerarquización del acontecimiento.

Como es tradición, en este periódico de formato sábana, las noticias comienzan a desarrollarse en la tapa y continúan en el interior; en este caso en la página 11 del rubro Economía. La nota ocupa allí alrededor del 35\% del espacio y está acompañada por dos gráficos a color, que presentan información estadística sobre la reducción de hectáreas sembradas de trigo, girasol y centeno, el primero, y sobre el descenso de toneladas de carne exportadas en el periodo que comprende los años 2005 a 2013, el segundo. Los gráficos actúan como editoriales porque el medio los elabora con la intención de impactar visualmente al lector con información negativa acerca de la situación económica del campo.

El diario titula en complicidad con el lector que sabe que esos 10 años corresponden a la gestión del matrimonio Kirchner. A esta estrategia Eliseo Verón llama efecto de reconocimiento, ya que la publicación da por sabido el contexto político y alude a él a través de una expresión que tiene relación. Puede observarse además, que el enunciado se inicia con un adjetivo evaluativo no axiológico -según la clasificación de Orecchioni- que antecede al verbo para expresar con mayor énfasis la cualidad; en este caso, la gravedad de la situación económica del agro. De igual modo, al categorizar como "campo" al sector rural, se emplea la estrategia de superficie de la generalización, que opera sacando conclusiones a partir de algunos casos y generalizando a todos los casos semejantes. Como ya señalamos en las UA 14 y 19, esta generalización puede ser empleada por La Nación para homogeneizar al sector agropecuario y que los reclamos de los estratos más altos sean entendidos como los reclamos de todo el conjunto.

La volanta "Magra cosecha", evalúa de manera negativa los rindes del sector, calificándolos de flacos. Al igual que en título, el enunciado comienza con un adjetivo evaluativo no axiológico 
para resaltar la cualidad del sustantivo. Mientras que la bajada menciona las producciones afectadas y otorga una cifra desfavorable para el agro: "Sectores como el trigo, el girasol y la carne producen menos que en 2003; desde 2008 desaparecen 1000 empresas agropecuarias por año".

El discurso de La Nación realiza un balance de la gestión kirchnerista en materia agropecuaria y otorga datos económicos desfavorables para el sector; procedentes de la Sociedad Rural Argentina y Coninagro, dos instituciones que mantienen fuertes diferencias con las políticas implementadas por el Gobierno Nacional, dejándose al margen las estadísticas del Ministerio de Agricultura y del Indec. La única cifra oficial que aparece pertenece al Ministerio de Trabajo de la Nación y también arroja resultados negativos para la actividad:

- “...desde hace cuatro años desaparecen casi 1000 empresas agropecuarias por año, según datos del Ministerio de Trabajo de la Nación”.

- "Según datos del Instituto de Estudios Económicos y Negociaciones Internacionales de la Sociedad Rural Argentina (SRA), del promedio de siembra de 5.829.333 hectáreas en las campañas 2003/2004 a 2005/2006, se cayó el año pasado a 3,6 millones. El cereal perdió $38 \%$ de área. Hace dos campañas, la superficie sembrada (3,1 millones de hectáreas) fue la peor en más de un siglo. Por el lado de la cosecha las cosas no fueron mejor. Del promedio de 14.383.333 toneladas de los ciclos 2003/2004 a 2005/2006, el volumen se redujo la última campaña a 10,1 millones. Un 30\% menos”.

- "Según datos de Coninagro, mientras hasta 2007/2008 se había crecido en indicadores de área y producción, hubo después un retroceso. Varias producciones no superan hoy niveles de otras épocas. Ejemplo: en 2012/13 se produjeron 708.000 toneladas de algodón, pero el récord se había dado en 1996, con 1.350.000. Es decir, se está casi en la mitad".

Al utilizar fuentes que poseen la misma orientación y no contrastarlas con otras que posean una visión divergente, el medio otorga una sola versión del tema a los lectores. Prieto Castillo denomina a esta estrategia uniacentualidad significativa y señala que la misma funciona en el plano de la organización del enunciado porque cada frase posee una intención.

En la noticia también aparece una fuente oficiosa utilizada por el enunciador para realizar un juicio de valor negativo sobre el Gobierno poniendo "en boca" de actores, cuya identificación es 
imprecisa, lo que quiere expresar: "En el sector coinciden en que el problema fue la receta que aplicó el kirchnerismo: más allá de la soja, que logró quedar al margen de las políticas oficiales y que sirvió como fuente de ingresos al Estado a través del cobro de retenciones, desde 2006 hubo permanentes trabas al comercio, intervenciones de mercado y cuotificación de las exportaciones que desalentaron la producción en sectores emblemáticos del país. A estos factores se sumó, en los últimos años, el retraso cambiario, que tuvo un fuerte impacto en muchos productos regionales”. En este fragmento puede observarse además, que el enunciador generaliza porque hace alusión a que en todo el sector agropecuario coinciden con lo señalado.

Teniendo en cuenta las proposiciones de las que habla van Dijk, en este discurso el "campo" es considerado como la víctima y el Gobierno Nacional como el victimario, como puede observarse en el siguiente fragmento: "Cultivo importante en zonas marginales, pero castigado con retenciones de $32 \%$ en su grano y $30 \%$ para sus subproductos, el girasol fue también afectado".

El discurso utiliza también la figura retórica de la ironía para denominar "década ganada" a la gestión de los gobiernos kirchneristas. Con esta estrategia, La Nación da a entender lo contrario de lo que dice, en complicidad con el lector que entiende la intención del medio: "La década ganada tampoco alcanzó a la carne".

En cuanto al cuadrado ideológico de van Dijk, el discurso enfatiza información negativa sobre el Gobierno Nacional y sobre la situación del agro; para ello, se vale de evaluativos axiológicos que aplican un juicio de valor del sujeto de la enunciación y una toma de posición respecto al objeto denotado:

- "Con la excepción de la soja, que logró un explosivo crecimiento en área y producción, para los principales productos del campo la 'década ganada' de gobiernos kirchneristas quedó trunca".

- “... para muchos sectores del campo han sido años malos o, en el mejor de los casos, mediocres".

- "El escenario tampoco es exitoso para la leche, cuya producción quedó en 2013 en 11.100 millones de litros, $10 \%$ por encima de los 10.111 millones de 2000 . No son buenos resultados si se considera, por ejemplo, el alza de $65 \%$ que tuvo en estos años Brasil (de 20.000 millones a más de 33.000 millones)”. 
La noticia también emplea la figura retórica de la hipérbole para exagerar los rasgos negativos de la situación del agro argentino. Estas descripciones inducen a pensar en un escenario caótico:

- "El cereal perdió 38\% de área. Hace dos campañas, la superficie sembrada (3,1 millones de hectáreas) fue la peor en más de un siglo”.

- "Mientras tanto, se desplomaron las exportaciones. Entre 2004 y 2007, la Argentina exportó por encima de los 9 millones de toneladas. Luego hubo una caída, una recuperación con 11,4 millones exportadas en 2012 y otro derrumbe a 3,2 millones en 2013".

- "La última campaña (de girasol) fue de las peores en 40 años".

A modo de síntesis, la gestión del matrimonio Kirchner está asociada en este discurso a los siguientes léxicos y predicaciones que aportan información negativa sobre la situación del agro: caída en la producción, despidos, desaparición de empresas agropecuarias, cierre de plantas frigoríficas, trabas al comercio, intervenciones de mercado, retraso cambiario, intervencionismo, cierre de exportaciones y controles, reducción del área de siembra, desplome de las exportaciones y férreo control. Todas estas expresiones pudieron ser utilizadas por La Nación para persuadir al lector e inducirlo a pensar que el Gobierno llevó adelante políticas desacertadas.

Teniendo en cuenta "lo dicho y lo no dicho", una de las estrategias de fondo planteadas por Prieto Castillo, en este discurso no se hace referencia al fenómeno denominado "avance de la frontera agropecuaria" de cultivos extensivos que ganan superficie en lugares donde tradicionalmente se realizaban producciones regionales como el algodón, la papa o los cítricos. Tampoco alude al hecho de que los productores eligen sembrar soja por la rentabilidad del cultivo, debido a los precios internacionales y al valor del peso argentino en comparación con el dólar. El enunciador oculta estos elementos que ayudan a explicar las causas del aumento de la producción sojera con la intención de responsabilizar al Gobierno de los "malos años" del campo y explica en otras palabras que a los productores no les quedó otra opción que la soja: "Contra el intervencionismo, los productores que pudieron se refugiaron en la soja". A diferencia de Página 12 que asocia al cultivo con la idea de rentabilidad. 


\section{II.4. Los controles de la Administración Federal de Ingresos Públicos (AFIP).}

"Hay una persecución a los productores por parte de la AFIP que está yendo a los domicilios fiscales y a los campos de los productores. Lo tomamos como una presión para amedrentar, atemorizar a los productores", sostuvo Luis Etchevehere, titular de la Sociedad Rural".

Página 12, 15 de febrero de 2013.

UA 30. La noticia seleccionada para este eje temático se encuentra ubicada en el rubro Economía en la edición del sábado 9 de febrero de 2013 del diario La Nación; ocupando alrededor de un $33 \%$ de la página 2.

El título "La AFIP intensificó la presión a los productores de soja", plantea la existencia de lo que Prieto Castillo denomina "relación de oposición", que alude a la existencia de un conflicto entre los sujetos que forman parte del discurso. Y, por otra parte, el diario La Nación asocia a la Administración Federal de Ingresos Públicos con el término "presión”, que posee connotaciones negativas.

La bajada expresa que el faltante de dólares es la causa de los controles que lleva adelante la AFIP para fiscalizar cuántas toneladas de granos poseen los productores y apresurar su comercialización: "Faltan dólares. El organismo aumentó las inspecciones para controlar los stocks, con el objetivo de acelerar su venta".

En el primer párrafo de la noticia se explica que los operativos de la AFIP se realizan "con el objeto de forzar su liquidación e inyectar dólares en el sistema por medio del cobro de retenciones, en un intento por frenar la escalada en la cotización de la divisa". Como puede observarse, el diario La Nación evalúa en términos negativos el accionar del Gobierno, al señalar que intenta obligar a los productores a vender soja para conseguir dólares.

En otro orden de ideas, la palabra "ajena" es insertada con fines polémicos, para descalificar el accionar del organismo recaudador del Estado y por ende, para evaluar de manera negativa las políticas económicas del Gobierno Nacional. El diario utiliza fuentes textuales institucionales oficiales buscando un efecto de realidad y veracidad; entre ellas, reproduce las declaraciones de Julio Currás, vicepresidente primero de la Comisión Nacional de la FAA (a); la palabra del 
presidente de la Sociedad Rural Argentina, Luis Miguel Etchevehere (b) y un comunicado de Acción Gremial de Federación Agraria Argentina (c):

a). "Muchos productores han recibido las visitas de los inspectores de la AFIP. Piden que declaren la cantidad de granos de soja en su poder. Hay casos en que lo han hecho de una forma agresiva y amenazante. Piden diligenciar formularios y entregarlos en 48 horas bajo amenaza de perder el registro de operador de agricultores', explicó Currás”.

b). "En diálogo con LA NACIÓN, el presidente de la Sociedad Rural Argentina, Luis Miguel Etchevehere, repudió ayer el operativo del AFIP: 'Vemos con gran preocupación que el Gobierno se gaste a cuenta una cosecha que todavía no se cuantifica. No pueden obligar a los productores a vender por medio de aprietes y actos intimidatorios', declaró”.

c). "Mediante un comunicado, el Comité de Acción Gremial de Federación Agraria Argentina denunció anteayer que `el gobierno nacional persigue, una vez más, a los productores, enviándoles a la AFIP a que controle existencias de soja, con un operativo de apriete inexplicable. Como es habitual en el kirchnerismo, se ve al sector agropecuario como salvavidas cuando se le complica la caja, cosa que les preocupa en un año electoral; al tiempo que siguen dándoles la espalda sistemáticamente a todos nuestros reclamos y pedidos'".

De igual modo, se utilizan fuentes oficiosas activas que se suman a los reclamos de las entidades que representan los intereses del agro:

- "Es inédito que la AFIP haga esta solicitud en enero. Generalmente, esta información se registra en diciembre, al cierre del año fiscal. Hoy he tenido una avalancha de pedidos de clientes que solicitan confirmar cuánto tengo de remanente. Piden detallar el lugar en donde tienen stock. Si no lo tienen en acopios, exigen los puntos de referencia para hacer rastreos satelitales', dijo el responsable comercial de una firma de granos”.

- “Alicia, una productora de Entre Ríos, recibió hoy en su domicilio a la inspectora: 'Vienen a nuestras casas a intimarnos. Es una violación a la propiedad privada. Están buscando que vendamos remanentes de soja, que en muchos casos son un stock que ya está vendido y que no nos pertenece. Ya somos varios los que nos hemos acercado a la Sociedad Rural para expresar nuestra preocupación'”. 
Haciendo un análisis de las declaraciones que aparecen en el discurso, puede observarse que el Gobierno Nacional está asociado con las siguientes expresiones negativas: "obliga a los productores a vender por medio de aprietes y actos intimidatorios", "persigue" a los productores, está "preocupado en un año electoral" y "da la espalda a los reclamos" del sector.

De igual modo, las actividades de fiscalización de la AFIP son evaluadas de manera negativa con las siguientes descripciones: "agresivas y amenazantes", "un operativo de apriete inexplicable", "Generalmente, esta información se registra en diciembre, al cierre del año fiscal”, intimación y "violación a la propiedad privada".

Como puede observarse no se utiliza como fuente a la AFIP para que explique el motivo de los operativos y sus hallazgos. En este sentido, cabe señalar que otorgar o vedar la palabra son estrategias intencionadas que se relacionan de manera directa con el posicionamiento del medio en la construcción del hecho.

La noticia es acompañada por un destacado periodístico titulado, "La pelea rural" en donde aparecen las fotografías de Etchevehere (a la izquierda) y la de Ricardo Echegaray, titular de la AFIP (a la derecha). Dichas imágenes corresponden a lo que Verón llama "retórica de las pasiones" por haber sido "arrancadas" a los personajes cuando su rostro expresaba una emoción. De manera implícita, el diario La Nación instaura un paralelismo entre víctima y victimario, entre productores y Gobierno, entre buenos y malos. Debajo de la imagen del referente rural aparecen sus declaraciones textuales, a través de citas directas, señalando que los productores se encuentran afectados por la inflación; mientras que debajo de la imagen del funcionario público aparecen descripciones negativas sobre el Organismo Estatal:

Luis Etchevehere, presidente de la Rural:

- "No nos van a amedrentar, no nos pueden obligar a vender".

- "Venimos de dos años muy malos de sequía e inflación. Vemos con gran preocupación que el Gobierno se gaste a cuenta una cosecha que aún no se cuantifica”.

- "El momento de vender lo decide el productor. Es él quien tiene el mejor criterio para determinar las condiciones del mercado que le favorecen".

- "Para los productores conservar los remanentes de la soja es la forma de protegerse ante la inflación local y los mayores costos". 
Ricardo Echegaray, titular de la AFIP:

- "Echegaray obliga a declarar las existencias de soja".

- "El ente recaudador lanzó un operativo que busca detectar stocks de soja acopiados por productores rurales. Quiere que el campo liquide esas existencias para obtener dólares provenientes de las exportaciones (mediante retenciones y liquidación de ventas al exterior).

- "Amenazó a los productores con quitarles registros oficiales necesarios para operar si no dan respuesta a sus requerimientos".

- "Tiene 1090 intimaciones en carpeta para realizar en los próximos días".

UA 31. La noticia titulada "Los esclavos de la soja" demuestra la contracara del modelo agrosojero al denunciar el hallazgo, por parte de la AFIP, de 157 trabajadores en condiciones inhumanas, dedicados al desmonte de campos en la provincia de Salta. Hecho que no aparece mencionado en el diario de los Mitre.

El discurso se encuentra en la edición del jueves 11 de abril de 2013 en el diario Página 12; ocupando el 50\% de la página 16 en el rubro Sociedad.

Su título más que anunciar un hecho, enuncia una situación y por otra parte, es editorial ya que califica como "esclavos" a los trabajadores que detectó la AFIP en campos ubicados a 30 kilómetros de la localidad de Dragones, al norte de la provincia de Salta.

La volanta, a su vez, aporta datos del contexto que ayudan a comprender el título: "Trabajo en condiciones infrahumanas en Salta”. Mientras que la bajada resalta la cantidad de personas halladas por el organismo estatal y la situación de las mismas: "La AFIP detectó en un campo la presencia de 157 trabajadores no declarados, entre los que había menores de edad. Vivían en chozas precarias y la comida debían comprársela al empleador".

En la presente UA, aparece la figura retórica de la paradoja ya que por un lado, describe la existencia de trabajadores en condiciones de esclavitud y por otra parte, señala que el propietario de las 16.600 hectáreas, que oficia como empleador, "declaró ventas totales por 70 millones de pesos en 2012". El enunciador contrapone estos datos para dejar en evidencia el accionar de un empresario millonario que explota a sus trabajadores y los somete a "condiciones infrahumanas". 
En cuanto a las proposiciones a las que alude van Dijk, en este discurso los 157 trabajadores precarizados son considerados víctimas; mientras que su patrón, el titular de los campos, aparece en el rol de victimario. A diferencia del diario La Nación, donde sus víctimas son los grandes productores y el victimario es el Gobierno Nacional, con sus políticas económicas e impositivas. Como pudo observarse en las UA 14, 15 y 19.

Teniendo en cuenta el cuadrado ideológico propuesto por van Dijk, el discurso brinda información positiva sobre la AFIP resaltando la importancia de sus operativos al descubrir la existencia de trabajadores en situación de esclavitud y al presentar posteriormente una denuncia ante el Juzgado Federal de Orán e informar "a los organismos del Estado nacional competentes en la lucha contra el trabajo ilegal, infantil, explotación laboral o sexual y trata de personas ante la presencia de situaciones de trabajo ilegal”. En términos de Bajtin, el órgano recaudador del Estado se encuentra en la "arena" de los medios, donde se lucha por la imposición de la valoración y es objeto de múltiples acentuaciones; positivas, en el caso de Página 12 y negativas, en el caso de La Nación, que lo describe como el organismo encargado de hostigar a los productores rurales presionando para la venta de soja.

En lo referido a la lexicalización, se utilizan las expresiones "esclavos", "trabajadores precarizados" y "trabajadores no declarados" para referirse a las 157 personas halladas por las AFIP en campos salteños; quienes aparecen asociadas además a las expresiones "sometidos", "condiciones infrahumanas", "precariedad" y "aislamiento" que denotan de manera negativa el estado en el que se encontraban viviendo y prestando sus servicios.

La noticia emplea además, evaluativos axiológicos que manifiestan una toma de posición en contra del objeto denotado y fustigan la situación de precariedad de los trabajadores:

- "Entre otras irregularidades, se verificó que la familia de un trabajador, compuesta por el matrimonio y sus hijos de 3 años, 2 años y 6 meses, dormía en una choza armada con palos y tela plástica, con un único colchón, lo que obligaba a algunos de ellos a descansar sobre la tierra".

- "Además, el lugar era insalubre, con temperaturas extremas y una gran presencia de insectos, víboras y otros animales, sin contar con medios de traslado y asistencia sanitaria. Las necesidades fisiológicas debían ser satisfechas a cielo abierto, a metros de las chozas y en letrinas". 
- "En cuanto a la alimentación, los trabajadores se veían obligados a comprar las mercaderías a su empleador, quien posteriormente se las descontaba de sus ingresos, con lo cual se veían significativamente recortados".

Se trata además, de un discurso de alta referencialidad, al acercarse lo más posible a un tema mediante una adecuada cantidad de información y detalles precisos de las condiciones en las que se encontraban los trabajadores:

- "Los inspectores constataron que los trabajadores, incluidos mujeres y niños, residían en los campos rurales en condiciones infrahumanas. Los trabajadores precarizados habitaban chozas construidas con plásticos y palos sobre la tierra que eran provistos por su empleador. Además, no poseían agua corriente, energía eléctrica, sanitarios, primeros auxilios ni sistemas de comunicación. Dormían en condiciones de total precariedad, sin elementos de aseo personal ni domésticos”.

- "Por otra parte, los niños no podían asistir a ningún establecimiento escolar, debido al aislamiento al que se veían sometidas las personas, dado que no contaban con ninguna posibilidad de desplazamiento hasta la localidad de Dragones, la más cercana a la finca, ubicada a 30 kilómetros".

- "Los lugares visitados tampoco cuentan con elementos de seguridad laboral, y se verificó también la falta de la indumentaria requerida por el alto riesgo que implica este tipo de tarea".

La fotografía que acompaña al texto posee un carácter documental. En la misma aparecen agentes de la AFIP y de la Policía salteña junto a un trabajador en uno de los establecimientos productivos donde se realizó el operativo.

UA 32. El discurso seleccionado para este análisis corresponde a una noticia del diario Página 12 en la cual se informa que la Justicia realizó 27 allanamientos "a pedido de la AFIP, en distintas compañías cerealeras sospechadas de utilizar empresas 'fantasma' para ingresar al mercado formal granos no declarados".

La noticia que es objeto de este análisis se encuentra ubicada en la edición del viernes 26 de abril de 2013 en el diario Página 12, ocupando el extremo inferior derecho de la página 15 en el rubro Economía. 
El título "A la caza de empresas fantasma"; por un lado, enuncia una situación más que anunciar un hecho y por otra parte, apela a la complicidad del lector que puede asociarlo con la conocida película "Los cazafantasmas". Con este recurso se pretende entretener e inducir a la lectura de la noticia.

La volanta, "Allanan cerealeras por presunta evasión fiscal" brinda elementos para la comprensión del título y utiliza términos de la jerga jurídica para no incriminar de manera directa a las compañías del rubro, teniendo en cuenta que existe una causa judicial que investiga el hecho.

En el discurso se resalta el accionar de la AFIP como organismo encargado de ejecutar las políticas impulsadas por el Poder Ejecutivo Nacional en materia tributaria y aduanera, a diferencia del diario La Nación para quien el ente posee una supuesta animosidad contra un sector del agro al titular en la UA 15, "La AFIP contra las cerealeras".

En el discurso se menciona el nombre de las cerealeras que se encuentran investigadas por la justicia y los mecanismos de evasión: "La creación de compañías pantalla permitía a las firmas multinacionales como Noble, Nidera, Alfred Toepfer, CHS y Louis Dreyfus reclamar el reintegro de IVA y Ganancias cuando exportaban los granos sin haber cancelado esos impuestos al momento de hacerse de la mercancía. También están involucradas grandes firmas locales como Vicentin y otras que operan en el mercado interno, como Gear, Ricedal Alimentos, Oliva y FAVA".

La palabra del "otro" es introducida a través de citas indirectas con fines polémicos, debido a que las justificaciones de una fuente textual oficiosa activa (las cerealeras) se contraponen con lo señalado por una fuente textual institucional oficial (la AFIP):

- "Las cerealeras argumentan, cuando se detectan estos casos, que la responsabilidad no recae sobre ellas, sino sobre el vendedor de los granos, ya que no pueden conocer a cada uno de sus proveedores. Desde la AFIP rechazan ese argumento y consideran que son las cerealeras las que contratan los servicios fraudulentos. Todavía no se determinó el monto de la evasión. La causa está radicada en el Juzgado Federal 2 de Lomas de Zamora, a cargo de Ferreiro Pella".

En cuanto a las predicaciones, en este discurso las cerealeras Noble, Nidera, Alfred Toepfer, CHS, Louis Dreyfus Vicentin, Gear, Ricedal Alimentos, Oliva y FAVA aparecen asociadas de 
manera negativa a una posible evasión fiscal por utilizar empresas "fantasma" para ingresar al mercado formal granos no declarados. A diferencia del diario La Nación en la UA 18, donde aparecen como víctimas de la presión del Gobierno para que comercialicen la producción.

Por otra parte, se predica acerca de los resultados de diferentes operativos efectuados por la AFIP a fin de controlar el pago de impuestos, con lo que se resalta el accionar del organismo:

- "En paralelo a la investigación, distintos procedimientos realizados por el organismo que conduce Ricardo Echegaray en la provincia de Misiones resultaron en la incautación de 214 toneladas de soja no declarada con un valor estimado de 570.000 pesos que iban a ser contrabandeadas al exterior. La mercadería se encontraba disimulada en diferentes envases para ocultarla del control aduanero e impositivo y evitar así el pago de derechos de exportación. Se estima que se evadió el pago de 200.000 pesos en impuestos”.

La noticia principal se encuentra acompañada de un recuadro titulado, "Aceptan a la UIF como querellante", en la cual se informa que "la Unidad de Información Financiera fue aceptada como querellante en una causa donde se investiga una presunta asociación ilícita físcal que habría utilizado falsos contribuyentes para comercializar productos agropecuarios, ocultando la verdadera identidad de los productores".

El discurso predica sobre el modus operandi de la presunta evasión fiscal: "Personas que simulaban ser productores o prestadores de servicios agropecuarios facilitaban y participaban en la presunta evasión tributaria, mediante comprobantes apócrifos comercializados por la organización. Esta presunta asociación ilícita funcionaba por lo general bajo una sociedad anónima encargada de la comercialización de granos, se valía de contribuyentes ficticios -a los que se inscribía como mayorista de cereales- y organizaba la logística de transporte, entrega en puerto, gestiones bancarias, etc. Luego se procedía a su inscripción en el Registro Fiscal de Operadores de Granos como acopiador”.

UA 33. "Por la cosecha de la soja, la AFIP redobló el control de campos", titula el diario La Nación en su edición del día domingo 23 de abril de 2013. La noticia se encuentra ubicada en la página 20 del rubro Economía; ocupando el 45\% de su espacio, del lado izquierdo y sobre la línea de indicatividad, lo que indica una manera de jerarquizar el hecho. 
Como ya se señaló en otras UA, el centenario diario ubica las noticias sobre la soja en el rubro Economía al considerar al cultivo como mercancía, pudiendo haberla situado en otra como Política, debido a que hacen referencia a la Administración Federal de Ingresos Públicos (AFIP) o en el suplemento Campo, de los sábados.

Como puede observarse, el título asocia a la AFIP con la palabra "control", que en este discurso posee connotaciones negativas.

Asimismo, la volanta conformada por la palabra "Ofensiva" es editorial ya que lanza un juicio de valor negativo sobre el accionar del organismo recaudador del Estado, ligado a los significados "ataque" o "embestida". Mientras que la bajada generaliza la opinión negativa de algunos ruralistas sobre el Gobierno: "Los agentes visitan establecimientos e inspeccionan en las rutas; los productores creen que se trata de una presión para que vendan el grano".

La noticia trata sobre los operativos que realiza la AFIP para controlar el documento de carga de porte exigido para el tránsito de la mercadería y la fiscalización de rendimiento de cultivo en los campos. Según el diario, estos controles son evaluados de manera negativa por los productores, que los toman como "una presión para que se desprendan de la soja y no la retengan en el campo".

En lo referido a las fuentes, el diario La Nación otorga la palabra a dos productores que exportan soja, ligados a la Sociedad Rural y a Confederaciones Rurales Argentinas (CRA) para probar el argumento central del discurso. Y, al igual que en otras UA, esta publicación deja de lado la voz de pequeños productores o chacareros que también, aunque en menor medida, siembran la oleaginosa y están nucleados en otras asociaciones:

- “En esta zona se pararon en las rutas 8 y 7 a pedir cartas de porte [un documento para el tránsito de la mercadería] a los camioneros, las cruzan con la razón social y después van al campo', contó Maximiliano Bordas, integrante de la Sociedad Rural de Río Quinto, en Villa Mercedes, San Luis”.

- "Según el ruralista, en los casos en que los inspectores ya fueron a los campos lo hicieron para estimar el rendimiento del productor. Eso lo hace un inspector de la AFIP que se sube a la cosechadora que tiene un equipo, conocido como monitor de rendimiento, que mide lo cosechado. 'Quieren ver cuánto producís', señaló Bordas, que cree que el objetivo 
de esta acción es 'meter presión impositiva para que la soja no quede en el campo' y se venda".

- "Néstor Roulet, ex vicepresidente de Confederaciones Rurales Argentinas (CRA), confió otro caso. Según dijo, en Wenceslao Escalante, en el sudeste cordobés, también hubo agentes del organismo de visita. 'También está pasando en Córdoba. A gente que estaba cosechando le llegó la AFIP y se pusieron a hacer control de cosecha [para estimar los rindes] ', indicó".

También utiliza una fuente oficiosa activa al insertar la palabra de un agente de la AFIP:

- "Desde la AFIP, una fuente confirmó los operativos. 'Se están haciendo, pero no como algo especial, sino como rutinario. Es algo normal', indicó. Según la fuente, esta acción no tiene 'ninguna intencionalidad' para que los productores vendan. Otra fuente oficial indicó que las operaciones son 'particulares', es decir, a partir de algún dato que siguen los inspectores".

Como puede observarse, esta cita es introducida con fines polémicos ya que si bien presenta la versión extraoficial del organismo nacional sobre los operativos que realiza, se contrapone con las expresiones de los productores. Asimismo, el enunciador del discurso, se aleja de las palabras del agente de la AFIP al citarlas de manera textual y entre comillas.

En este discurso, la AFIP aparece asociada a expresiones y léxicos negativos: redobló el control, volvió a la carga, ofensiva, presión e intimidación. Que construyen la idea de un ataque del Estado hacia el campo, de un Gobierno deseoso de dólares y un sector agobiado por la carga impositiva, del victimario y la víctima. Esto es a lo que Prieto Castillo llama Relación de oposición debido al conflicto que existe entre los sujetos a los que alude la noticia: el Gobierno y el "campo". Y, por otra parte, teniendo en cuenta el cuadrado ideológico de van Dijk se enfatiza información negativa sobre el Gobierno.

Por su parte, la fotografía, que ilustra dos máquinas cosechando un campo con soja, posee un uso documental que adhiere a la realidad.

UA 34. Con el título "El oscuro camino del cereal", Página 12 califica de manera negativa la existencia de granos sin declarar en la AFIP y por lo tanto, deja sentado su posicionamiento 
editorial respecto al tema. De igual modo, puede observarse que no se trata de un titular informativo y su comprensión se logra al leer los demás elementos de lectura rápida.

En la volanta se resalta la magnitud de los productos irregulares: "La AFIP detectó 300 mil toneladas de granos no declarados". Mientras que en la bajada se destaca el accionar de la entidad estatal: "Operativos de fiscalización sobre la cosecha gruesa que llevó a cabo el organismo fiscal permitieron detectar un volumen significativo de granos no declarados, dando lugar a una evasión impositiva de 138 millones de pesos".

La noticia está ubicada en la edición del 18 de julio de 2013; en la página 4 del rubro Economía, ocupando un $60 \%$ de su espacio sobre la línea de indicatividad, lo que señala una manera de jerarquizar el hecho.

La UA que nos ocupa realiza una descripción pormenorizada de los distintos operativos llevados a cabo por la AFIP en predios rurales de Buenos Aires, La Pampa, Mendoza, San Luis, Córdoba, Santa Fe, Entre Ríos, Corrientes, Misiones, Chaco, Santiago del Estero, Tucumán y Salta. Las fiscalizaciones también se realizaron en acopios, silos, rutas y estaciones de trenes; en donde se halló soja, maíz, girasol, trigo, sorgo, arroz y porotos sin declarar. Se trata de un discurso de alta referencialidad que acerca lo más posible a un tema, mediante una adecuada cantidad de información y detalles precisos.

En este discurso de Página 12, al igual que en la UA 31 se destacan las acciones de la AFIP como ente recaudador de impuestos del Estado, configurando una imagen positiva del organismo; a diferencia del diario La Nación en las UA 30 y 33 donde señalan que el órgano “intensificó la presión a los productores de soja". Como puede observarse, la AFIP es objeto de múltiples acentuaciones o valoraciones, por lo que, se trataría de un signo pluriacentuado según lo planteado por Bajtín.

En cuanto a la polifonía de voces, el discurso emplea como fuente textual institucional oficial un comunicado de la AFIP, que oficia de voz autorizada.

La noticia predica que la AFIP descubrió deudas millonarias al fisco por parte de productores, hecho que no aparece mencionado en las páginas del diario La Nación:

- “... detectó alrededor de 300 mil toneladas de cereales no declarados que representan una evasión impositiva de 138 millones de pesos". 
- “... en otros controles sobre camiones y trenes se secuestraron 33.062 toneladas de cereal que eran movilizadas sin comprobantes. El cereal interdictado tiene un valor aproximado de 86 millones de pesos”.

- “... se recuperaron deudas de impuestos por cuatro millones de pesos a partir del embargo de cereal de contribuyentes deudores con ejecuciones fiscales en trámite”.

En cuanto a los subjetivemas, se emplea un evaluativo no axiológico para señalar que se trata de una distinguida evasión de impuestos: "La magnitud de las irregularidades detectadas es relevante, de hecho la evasión de impuestos estimada alcanza los 138 millones de pesos”.

Finalmente, en lo que respecta a la fotografía, se trata de una imagen que documenta un operativo de la AFIP a la vera de una ruta, en donde aparecen agentes del organismo y pueden observarse camiones que transportan granos.

UA 35. La unidad de análisis seleccionada se encuentra en la edición del 21 de febrero de 2014 del periódico La Nación y ocupa alrededor del 15\% de la página 14, perteneciente al rubro Economía. La cantidad de espacio empleado y su ubicación en la mitad de la página denotan que el hecho no se encuentra jerarquizado, a diferencia del mismo acontecimiento construido en Página 12, donde fue anunciado en el $80 \%$ de su tapa y ocupó las páginas 2 y 3; es decir, las más importantes de un periódico; como veremos en la UA 36.

A través de los elementos de la titulación, La Nación señala de manera implícita que el Gobierno aumentará la fiscalización al campo: "Profundizan el control sobre la comercialización de la cosecha”. Y en la bajada se destaca la posible ampliación de los gastos operativos que demanda la nueva medida: "La AFIP dispuso que los acopiadores den información que se seguirá en tiempo real; habría más costos para los operadores".

En contrapartida con el discurso de Página 12, el diario La Nación suprime información negativa sobre los ruralistas nucleados en la Mesa de Enlace y las grandes cerealeras y en cambio, destaca información negativa sobre el nuevo registro de granos; para ello, emplea la palabra de un contador y de una consultora que advierten sobre los plazos establecidos para informar sobre el stock de granos y sobre el costo administrativo que requiere para los operadores: 
- "Es muy preocupante el estrecho plazo de 24 horas para comunicar a la AFIP cualquier movimiento', sostuvo Santiago Sáenz Valiente, contador".

- “Se verá incrementada la carga administrativa que conjuntamente con otros regímenes agobian a la cadena', destaca un informe de la consultora Barrero \& Larroudé".

La Nación señala de manera implícita que la medida perjudica a los productores y acopiadores de granos por el escaso tiempo que tendrán para informar y por el dinero que demandará el trámite. De igual modo, da a entender que el requisito resulta innecesario porque la información solicitada ya se entrega a la cartera productiva: "Los acopiadores, que ya suministran información al Ministerio de Agricultura, tienen la sensación de que comunicarán dos veces lo mismo. Conceptualmente es equivalente al libro de movimientos y existencias de granos aún vigente. La duda es si deberá declararse dos veces lo mismo', opinó Leandro Pierbattisti, asesor de la Federación de Acopiadores".

El discurso utiliza una fuente oficiosa con actores cuya identificación es imprecisa a fin de polemizar y señalar que la medida adoptada por el Gobierno se produce en el marco de la "pelea" con el campo: "Según algunas fuentes, luego de la pelea con el campo por la soja sin vender, con esta herramienta el Gobierno tendrá más control sobre lo que ocurre con la comercialización".

Por otra parte, se otorga la palabra al máximo representante del ente recaudador del Gobierno para luego desacreditarlo teniendo en cuenta que se agrega la apreciación de uno de los representantes de la Mesa de Enlace: “Ayer, el jefe de la AFIP, Ricardo Echegaray, indicó no obstante que 'no hay más control. Es un paso más en la informatización del movimiento de granos', indicó. 'No hay más control, sino que se informatizó', insistió. (...) Rubén Ferrero, de Confederaciones Rurales Argentinas (CRA), remarcó que la medida 'se suma a controles ya existentes'",

Como puede observarse la nueva medida de la AFIP es objeto de múltiples acentuaciones; es decir que, como señala Bajtín, es un signo pluriacentuado. Para el diario Página 12 se trata de una medida que "servirá al Estado para combatir la evasión y maniobras especulativas" (UA 36); mientras que para La Nación "profundizará el control sobre la comercialización de la cosecha" y con ella "habría más costos para los operadores". 
UA 36. El 21 de febrero de 2014, el diario Página 12 construyó el acontecimiento sobre el nuevo registro electrónico de la AFIP para declarar la existencia de granos almacenados como "el" tema de la jornada; anunciándolo desde su portada.

Fiel a su estilo creativo e innovador, el matutino dedica alrededor del $80 \%$ de su tapa para informar el hecho. El título, "Cuentas claras" se encuentra en letras mayúsculas, negritas y cursivas, y además, en cuerpo catástrofe para llamar la atención del lector. Como puede observarse, utiliza un lenguaje coloquial y poco informativo, pero que a su vez es editorial porque conlleva a pensar en el refrán "Cuentas claras conservan la amistad". Como señala Ulanovsky (1997: 335) lo diferente en Página 12 es la utilización de, “títulos con humor, irreverencia o ironía, basados tanto en paráfrasis de nombres de películas como en dichos populares". Además, de ofrecer tapas con un "estilo vibrante y con ideas gráficas distintas (desde dibujos a fotos especialmente producidas, desde resoluciones tipográficas o fotomontajes)".

La bajada aporta datos para comprender el hecho "La AFIP creó un registro on line de las existencias de granos almacenados en silos o acopios". Y, resalta los aspectos positivos de la medida: "La información le servirá al Estado para combatir la evasión y las movidas especulativas".

Por su parte, la imagen que acompaña al texto es un fotomontaje que consiste en un contador o ábaco (instrumento para hacer cálculos manualmente) que en vez de cuentas redondas posee semillas de soja, ubicado sobre un montículo de semillas y de las chauchas que las contienen.

En el interior del diario, el acontecimiento se ubica en el rubro Economía, en las páginas 2 y 3 (las más importantes de la publicación), dispuesto a modo de "falsa central" y ocupando un 60\% del espacio total de ambas páginas; lo cual indica jerarquización.

El título que utiliza esta vez para referirse al hecho es: "Piedra libre a quienes se guardan la cosecha". El medio se vale de una expresión de uso popular perteneciente al juego de la "Escondida" para indicar que un participante fue descubierto. En este sentido, el matutino nacional titula en complicidad con el lector que sabe a lo que se refiere; estrategia que Verón llama "efecto de reconocimiento". Como veremos a lo largo de este estudio, Página 12 utiliza titulares poco informativos que enuncian una situación más que anunciar un hecho y de manera creativa buscan atrapar la atención del lector. 
La volanta, más informativa, anuncia que "La AFIP creó un registro online de las existencias de granos almacenados en acopios y silos bolsa". Mientras que la bajada agrega datos temporales y destaca de manera positiva los atributos de la nueva herramienta del Estado: "Los acopiadores de cereales y oleaginosas deberán informar desde el $1^{\circ}$ de abril sus tenencias de producción en un registro informático. La información le servirá al Estado para combatir la evasión y maniobras especulativas". Como vimos en la UA 35, a diferencia de Página 12, el diario La Nación describe al registro de manera negativa y lo relaciona con una medida adoptada por el Gobierno en el marco de la "pelea" con el campo: "Según algunas fuentes, luego de la pelea con el campo por la soja sin vender, con esta herramienta el Gobierno tendrá más control sobre lo que ocurre con la comercialización” (21-02-2014).

El discurso otorga una versión de alta referencialidad que acerca lo más posible al tema. Es así que brinda detalles precisos sobre el registro informático de granos almacenados en campos o acopios. Al respecto señala que: "Desde diciembre de 2009, esta operación se hacía de manera manual y la AFIP no tenía un control en tiempo real de las existencias de los granos. Además, muchos productores grandes, incluso las multinacionales que cuentan con acopios en sus propios campos, no estaban obligados a declarar desde el momento de la cosecha cuál era su stock. Sí lo hacían al momento de vender el grano, pero esta situación habilitaba a las multinacionales y grandes productores a guardar en sus silos y silos bolsas parte de la cosecha”.

Teniendo en cuenta el cuadrado ideológico de van Dijk, en el discurso se enfatiza información negativa sobre:

- Los ruralistas representados por la Mesa de Enlace que "suelen decir que" el aumento en el precio del pan se produce "por falta de trigo. Sin embargo los propios dirigentes reconocen que el grano está almacenado".

- Y, sobre las grandes cerealeras que, "tenían la capacidad de presionar al gobierno nacional a partir de la no liquidación de granos retenidos, esto se debía a que podían mantener los granos en sus silos sin declarar".

Mientras que se expresa información positiva sobre el registro online ideado por el Estado: “A partir de la sistematización del registro de los granos acopiados, el Estado podrá saber quién es el dueño del grano y dónde está almacenado. El caso del trigo es emblemático, ya que es un insumo básico para la industria alimentaria". 
Según la clasificación de Lucrecia Escudero, el diario emplea como fuentes textuales institucionales oficiales, la palabra de Ricardo Echegaray, titular del ente recaudador del Estado y fragmentos de la Resolución de la AFIP 3593 publicada en el Boletín Oficial, para explicar en qué consiste el registro. Ambos enunciados se producen en función de la persona y la institución que emiten un mensaje, por lo tanto se tratan de citas autorizadas:

- "Hasta ahora podíamos saber cuánto hay en poder de los productores, pero los granos en manos de los acopiadores sólo podíamos estimarlos a través de las diferentes fuentes de información. Los acopiadores pueden ser exportadores o proveedores de los molinos o las multinacionales. Ahora sólo resta informatizar el formulario por el cual los productores informan que entregaron granos en consignación a los acopios', sostuvo ayer Ricardo Echegaray durante un encuentro con periodistas".

- "Se hace necesario simplificar la operatoria de registración de movimientos físicos de granos y consolidar la captación de dicha información a los efectos de agilizar su utilización, adecuándola a los avances que incorporan los operadores, tanto en lo que se refiere a los sistemas de comercialización como al manejo físico de los granos y el consiguiente reflejo tributario', sostiene la resolución publicada ayer".

Por otra parte, emplea como fuente un medio de comunicación para abrir la polémica y luego brindar información negativa sobre los ruralistas nucleados en la Federación Agraria:

- “ ¿Dónde está el trigo no comercializado?', le había preguntado por radio Marcelo Longobardi a Eduardo Buzzi, titular de la Federación Agraria. Con algo de sorna, el ruralista respondió que estaba almacenado en silos y silos bolsas".

La fotografía que acompaña al texto ilustra cuatro silos y una gran cantidad de silobolsas y posee una función documental ya que intenta adherir a la realidad y probar la existencia de granos almacenados. El epígrafe señala: "El Gobierno sistematizó el registro de granos almacenados en los campos de los productores, de todas las escalas, o en los acopios". 


\section{II.5. Organismos Genéticamente Modificados.}

"Hoy no se puede pensar la sustentabilidad sin tecnología, y estoy seguro que INTACTA será beneficiosa para la Argentina, justamente por contribuir para proteger y preservar este planeta al que llamamos 'casa' y para mejorar la calidad de vida de las personas...". Pablo Vaquero, vicepresidente de Monsanto Latinoamérica Sur ${ }^{33}$.

"La disputa por los transgénicos no tiene que pasar por si usar o no usar, sino bajo qué modos, de qué manera, con qué marcos regulatorios, con qué controles y en beneficio de quién".

Pablo Pellegrini, biotecnólogo y doctor en Ciencias Sociales y Filosofía del Conocimiento ${ }^{34}$.

UA 37. El miércoles 22 de agosto de 2012, Página 12 anuncia en dos columnas y 17 líneas la presentación de Intacta RR2 Pro, la segunda generación de soja elaborada por la compañía multinacional Monsanto para ser comercializada en nuestro país. La noticia ocupa alrededor del $12 \%$ de la página 7 , en el rubro Economía y se halla en el extremo inferior de la hoja en un recuadro que acompaña a la noticia titulada "Respetar la propiedad intelectual", que informa el envío al Congreso de un proyecto para una nueva ley de semillas.

El anuncio de la nueva semilla por parte del Ministerio de Agricultura, Ganadería y Pesca de la Nación pasa casi inadvertido en este matutino, a diferencia del diario La Nación, donde el mismo acontecimiento ocupa el $50 \%$ de la tapa del suplemento Campo del 25 de agosto de 2012 y el 90\% de la página 6 , como veremos en la UA 38.

Cabe destacar, que Página 12 clasifica la noticia como un hecho económico, relacionado con la comercialización del producto, y no así con un hecho político que requirió la aprobación de la semilla por parte de un organismo estatal. La Nación, por su parte, propone otro tipo de recorrido para el lector y ubica el acontecimiento en el suplemento Campo, entendiendo que los beneficios productivos de la nueva semilla genéticamente modificada, pueden resultar de interés para los productores agropecuarios que compran el diario.

\footnotetext{
${ }^{33}$ En revista Amanecer Rural. Edición especial Diciembre No 127. Pág. 56.

${ }^{34}$ En Página 12, lunes 30 de diciembre de 2013. Pág. 16.
} 
La noticia titulada "La segunda generación de soja" reproduce la palabra - a través de una cita mixta- del entonces máximo funcionario de la cartera productiva Nacional, quien subrayó los beneficios económicos del nuevo producto y manifestó la existencia de "estrictos controles" para la autorización de la venta de semillas: "El ministro de Agricultura, Norberto Yauhar, destacó ayer que la aprobación de 'la segunda generación de soja', luego de estrictos controles, permitirá incrementar en 11 por ciento la producción del grano en la misma cantidad de suelo, según los estudios ya realizados en Brasil".

El diario también le otorga la palabra al vicepresidente de Monsanto, Pablo Vaquero, quien resalta los atributos positivos de Intacta RR2 Pro: "reúne tres beneficios: gracias al gen BT ofrece protección contra insectos lepidópteros, máxima tolerancia a la aplicación de glifosato y mayor productividad". Ambas declaraciones pertenecen a fuentes textuales institucionales oficiales que actúan como voces autorizadas para hablar sobre el tema.

Este discurso, posee una versión de baja referencialidad, clasificación elaborada por Prieto Castillo para señalar que una versión ofrece unas pocas notas de algo, con la intención de que con ellas de agote todo. Según van Dijk, los discursos tienden a ser relativamente incompletos cuando hablan acerca del grupo o ideología al que alguien pertenece. En este sentido, cabe señalar que no aparecen detalles específicos sobre los estudios realizados para determinar si la semilla es segura, ni aparece la palabra de quienes se manifiestan en contra del consumo de alimentos provenientes de Organismos Genéticamente Modificados (OGM).

UA 38. La noticia seleccionada para este análisis es, sin dudas, el acontecimiento principal del suplemento Campo del diario La Nación, en su edición del sábado 25 de agosto de 2012. La jerarquización de las notas sobre la aprobación de la nueva variedad de soja de Monsanto puede observarse desde la tapa, que ocupa el 50\% del espacio con una extensa fotografía en donde aparecen semillas de soja y un título desplegado en formato "bandera". En la página 6 del suplemento continúa el desarrollo de la noticia, cuyo título también ocupa todo el ancho de la página. Aparecen también otras dos noticias que se incluirán en el análisis por referirse al mismo tema y cinco fotografías que documentan el hecho. Todos estos elementos ocupan el $90 \%$ del espacio de la página mencionada, lo que indica una jerarquización del acontecimiento. 
El título, "La biotecnología vuelve a ser la mejor aliada" califica de manera positiva el uso de semillas modificadas de manera genética al emplear un adjetivo superlativo no axiológico, que expresa una cualidad en su máxima intensidad.

En la volanta "(Semillas) Nuevos lanzamientos comerciales", hace explícito que el diario La Nación se encuentra presentando los productos de una de las compañías que publicitan en sus páginas y que aparece mencionada en la bajada: "La aprobación de la nueva soja de Monsanto y más eventos en maíz permiten acortar distancias con Brasil”.

Por su parte, el primer párrafo amplía la información de la bajada y señala que nuestro país retomó el uso de la biotecnología y se aproxima a Brasil en cuanto a los eventos autorizados:

- "La Argentina se ha puesto definitivamente, otra vez, en el camino de la carrera biotecnológica y quedó más cerca de alcanzar a Brasil en materia de cantidad de eventos autorizados. La aprobación del Gobierno y el lanzamiento que hizo esta semana la firma Monsanto de su soja Intacta RR2 PRO, la 'heredera' del evento de 1996 que ahora llega con una nueva tecnología de tolerancia al glifosato e incorpora la resistencia a insectos, fue la confirmación de esa tendencia. Sumando la nueva soja y el recientemente quíntuple apilado en maíz de Dow Agrosciences, el país cuenta con 27 eventos aprobados comercialmente, entre maíz, soja y algodón. Brasil posee 33 para los mismos productos y poroto. Y los Estados Unidos tienen 91, entre diversos cultivos...”.

Por otra parte, se utilizan fuentes textuales institucionales oficiales pertenecientes a compañías que comercializan semillas genéticamente modificadas y a una asociación relacionada al sector. La palabra del "otro" es insertada a través de citas directas en su calidad de cita autoridad y para ratificar lo expuesto por el enunciador del discurso en cuanto a la competitividad biotecnológica. Cabe destacar que en todas las declaraciones se califica de manera positiva la aprobación de la nueva semilla de Monsanto:

- "La aprobación de la nueva soja, sin duda, vuelve a poner a nuestro país en carrera frente a Brasil. Hoy no sólo se ha alcanzado un número similar de eventos aprobados [en soja], sino que el sector productivo podrá contar con las últimas tecnologías $\mathrm{y}$, por lo tanto, recuperar competitividad. Esta aprobación, junto con las últimas de maíz, reposiciona a la Argentina como líder regional y también mundial en materia regulatoria debido al ritmo 
acelerado con que se efectuaron', expresó Gabriela Levitus, directora ejecutiva de ArgenBio".

- "Estamos recuperando competitividad y la reciente aprobación en soja, acompañado de un modelo de captura de valor, nos pondrá en dos a tres años a tiro de Brasil", dijo Ignacio Conti, gerente de marketing del negocio de semillas oleaginosas de Dow Agrosciences.

- “La aprobación de la nueva soja es una excelente noticia para el país. Nos ayuda a aumentar la competitividad de nuestros productores y de nuestro país y genera condiciones más favorables para atraer nuevas inversiones en el sector', afirmó, por su parte, Carlos Becco, director de soja de Syngenta".

- 'Desde Don Mario, Manuel Mihura, director de estrategia y nuevos negocios, coincidió: 'Es una excelente noticia y para la Argentina es un gran paso de los tantos que tienen que ir sucediendo para intentar construir y recuperar el camino del liderazgo tecnológico que supo tener'”.

Por otra parte, el discurso evalúa de manera favorable la política llevada adelante por el Gobierno Nacional en materia biotecnológica. Cabe destacar que se trata de la única UA del diario La Nación donde se califica como acertada a una decisión política del Ejecutivo Nacional:

- "Es, tal vez, la única política acertada que ha tenido el kirchnerismo en la relación con el campo, luego de destruir con su intervención los mercados de carne, trigo y leche”.

Para reforzar esta idea utiliza como fuente textual institucional oficial la palabra del máximo referente de la Asociación de Semilleros, a través de citas directas e indirectas:

- “Ahí Brasil nos sobrepasó. Perdimos terreno porque faltaba la decisión política de que la biotecnología era una política de Estado', señaló Miguel Rapela, director ejecutivo de la Asociación de Semilleros Argentinos (ASA). Sin embargo, según Rapela, esa situación comenzó a cambiar con la llegada de Julián Domínguez a la cartera de Agricultura. El actual presidente de la Cámara de Diputados de la Nación y ex ministro de Agricultura introdujo cambios que son considerados positivos".

- "Faltaba decisión política de que la biotecnología debía ser política de Estado, pero eso se tomó desde Domínguez en adelante y se modernizó el proceso de evaluación y administrativo y de desregulación. Así, de los cuatro años que demandaba un proceso de desregulación ahora eso está en alrededor de dos años', indicó Rapela”. 
Otro hecho en el que focaliza el discurso es en la aprobación de una nueva ley de semillas que contemple el pago de regalías por la propiedad intelectual de los adelantos biotecnológicos. En este sentido, cabe indicar que el centenario diario reproduce la palabra de quienes están a favor de cobrar regalías a los productores agrarios cada vez que siembren alguna variedad de semilla modificada genéticamente y deja de lado los argumentos de las asociaciones de agricultura familiar y pueblos originarios que luchan en defensa de las semillas nativas y criollas, medio fundamental para la soberanía alimentaria.

Al reproducir opiniones "a favor" que poseen la misma orientación de sentido y omitir argumentos "en contra", el diario se posiciona respecto al tema:

- “A todo esto, Rodolfo Rossi, fitomejorador de soja de Nidera, subrayó: `... Las empresas propietarias de las nuevas tecnologías todavía mantienen una actitud de observación sobre si se modifica favorablemente en el país la incierta situación referente a la propiedad intelectual en semillas, germoplasma y eventos'".

- "En este contexto, Ricardo Reddy, director del semillero Sursem, explicó que una nueva ley de semillas podría permitir a las empresas recuperar sus inversiones. 'Sería importante que se concrete la sanción de una nueva ley de semillas que contemple la protección de las obtenciones intelectuales y permita recuperar las inversiones que las empresas hacen durante años para lograrlas', opinó".

En lo referido al detalle o nivel de descripción que plantea van Dijk, se trata de un discurso incompleto que, como ya lo señalamos, sólo contempla argumentos a favor del pago de un plus por el valor agregado de tecnología y omite mencionar la lucha que llevan adelante campesinos, pueblos originarios y agricultores familiares para garantizar el intercambio, comercialización y libre uso de las semillas:

- "Precisamente, en la industria semillera admiten que el punto que falta terminar de cerrar es el vinculado con la propiedad intelectual. Hoy la ley de patentes protege el evento, como el que patentó Monsanto. Vale recordar que Monsanto impulsó la firma de cartas donde productores que representan el 68\% del área sembrada a nivel país (y más del 90\% en el Norte) ya manifestaron su conformidad en pagar regalías".

En cuanto a la noticia titulada "Las empresas aceleran la llegada de tecnología" que acompaña en la misma página a la nota principal, el diario La Nación informa a los productores agropecuarios 
A) sobre las nuevas semillas que podrán adquirir en poco tiempo más, explicando los atributos que presentarán los nuevos eventos y B) sobre los acuerdos existentes entre diferentes compañías para la investigación, elaboración y comercialización de nuevas variedades de soja:

A) "Rodolfo Rossi, de Nidera, firma que igual que Don Mario ya está preparada para lanzar las nuevas sojas Intacta RR2 PRO el próximo año en el Norte, comentó que hay proyectos avanzados en tolerancia a glifosato más dicamba y resistencia a insectos; tolerancia a glifosato y glufosinato más tolerancia a la familia de herbicidas HPPD; tolerancia al glifosato más al 2,4 D más glufosinato; combinaciones de tolerancia a herbicidas con nuevos eventos de resistencia a insectos lepidópteros; eventos de mayor rendimiento y tolerancia al estrés y eventos de calidad de aceite para la usos comestibles".

B) "... se sabe que Monsanto tiene convenios con Don Mario, Nidera, Sursem y Syngenta, entre otras, para la llegada de esta tecnología. (...) Syngenta tiene un acuerdo de investigación con Monsanto y está desarrollando a toda velocidad variedades RR2Bt que estarán en el mercado en cuanto se autorice su comercialización', indicó Carlos Becco, director de soja de Syngenta. Además, Becco precisó: 'Estamos trabajando en el desarrollo de un evento biotecnológico que permitirá incorporar a la soja resistencia a una nueva familia de herbicidas y complementar la acción del glifosato a través de una nueva herramienta'”.

Por su parte, la subnota titulada "Apoyo a la propiedad intelectual" destaca la labor del Ministerio de Agricultura de la Nación en la aprobación de semillas y variedades biotecnológicas y en el reconocimiento a la propiedad intelectual, como primer paso hacia el pago de regalías a los dueños de las patentes. Para ello, utilizan como fuente textual institucional oficial, la palabra del entonces secretario de Agricultura de la Nación, Lorenzo Basso y un informe de su área, en calidad de cita autorizada y como prueba de lo expuesto:

- "De acuerdo con el funcionario (el secretario de Agricultura de la Nación, Lorenzo Basso), la modificación de la ley de semillas `avanzará sobre el reconocimiento de la propiedad intelectual del germoplasma ${ }^{35 \prime \prime}$.

\footnotetext{
${ }^{35}$ Significa recurso genético.
} 
- "Según un informe del área de Basso, desde la creación del Ministerio de Agricultura en los últimos tres años se aprobaron 14 eventos versus los 13 que se habían autorizado en los primeros diecisiete años desde que se creó el marco regulatorio en la Argentina. Vale recordar que en 1991 se creó la Conabia (Comisión Nacional Asesora de Biotecnología Agropecuaria)".

A modo de síntesis y trazando un mapa de predicaciones, se observa que en las tres noticias analizadas se califica de manera positiva la aprobación de la nueva semilla Intacta RR2 PRO y el empleo de biotecnología. Hechos que aparecen asociados a las siguientes expresiones: "permiten acortar distancias con Brasil", "recuperamos terrenos perdidos", "más cerca de alcanzar a Brasil", "recuperando competitividad", "aumentar la competitividad de nuestros productores", "favorable para traer nuevas inversiones en el sector", "excelente noticia", "gran paso", "recuperar el camino del liderazgo tecnológico", "avance" y "aliada".

Para finalizar, las fotografías que aparecen acompañando la noticia documentan el hecho. En las mismas aparecen: 1) Una bióloga investigando en un laboratorio. 2) El entonces ministro de Agricultura Norberto Yauhar junto a Bernardo Calvo y Pablo Vaquero, presidente y vice, respectivamente, de Monsanto, en la presentación de la nueva soja. 3) El rostro de Rodolfo Rossi de Nidera. 4) El rostro de Miguel Rapela de la Asociación de Semilleros. 5) Y el rostro de Lorenzo Basso, entonces secretario de Agricultura.

UA 39. El discurso seleccionado se ubica en el suplemento Campo del diario La Nación en su edición del sábado 3 de septiembre de 2012; ocupando un 15\% de la página 3, la primera en importancia después de la tapa.

El título "Destacan el papel de los transgénicos", adelanta que la noticia brindará argumentos positivos para la utilización de semillas genéticamente modificadas en la agricultura. La volanta "Internacionales" indica que el hecho se realizó fuera del país. Mientras que la bajada resalta uno de los atributos principales de la utilización de transgénicos según lo señalado en la conferencia: "Son claves para la competitividad', dijo un foro internacional".

El primer párrafo reproduce una recomendación de la II Conferencia Mundial sobre Investigación Agrícola para el Desarrollo (Gcard), en donde solicitan que Latinoamérica 
prospere en el uso de cultivos genéticamente modificados que hayan recibido fuertes controles para garantizar la seguridad alimentaria:

- “América latina debe avanzar en la utilización de cultivos transgénicos siguiendo principios de selectividad y asegurando férreos controles que den seguridad a los consumidores sobre su uso, dijeron este martes los expertos reunidos en la II Conferencia Mundial sobre Investigación Agrícola para el Desarrollo (Gcard)”.

En cuanto a las fuentes, se trata de un discurso realizado por la agencia internacional FrancePresse (AFP), como señala al comienzo del primer párrafo.

De manera implícita el discurso señala que los transgénicos son seguros y no ocasionan daños a la salud, en este sentido se vale de la palabra autorizada de Claudio Barriga, vicepresidente del Foro Global de Investigación Agropecuaria (GFAR), quien señala: “... los males que se adjudican a los transgénicos son un 'mito', ya que 'no hay ningún caso de que el transgénico haya sido perjudicial para la salud o haya causado muerte'".

De igual modo, se predica que el uso de transgénicos no causa daños al medio ambiente y para ello, emplea la palabra autorizada A) del entonces ministro de Ganadería, Agricultura y Pesca uruguayo, Tabaré Aguerre y B) de Emilio Ruz, secretario ejecutivo del Programa Cooperativo para el Desarrollo Tecnológico Agroalimentario y Agroindustrial del Cono Sur (Procisur):

A) "Sobre los efectos nocivos que algunas organizaciones sociales y medioambientales adjudican a los transgénicos, especialmente sus efectos sobre la biodiversidad, el ministro Aguerre señaló que ‘fácilmente con reglamentaciones de manejo de la agricultura se pueden conservar los centros de biodiversidad'".

B) "Ruz, a su vez, destacó que 'la tecnología de los transgénicos ha traído a la región una carga de agroquímicos menor', lo que reduce el impacto ambiental de la agricultura".

A modo de síntesis, en esta noticia, los transgénicos están asociados a léxicos positivos: "competitividad", expansión de la producción agrícola y "reducción del impacto ambiental de la agricultura".

UA 40. El discurso seleccionado pertenece al diario La Nación y fue publicado en su edición del sábado 16 de febrero de 2013. Se encuentra ubicado en la página 5 del suplemento Campo, ocupando un 50\% del espacio, sobre la línea de indicatividad. Cabe señalar que el acontecimiento 
se encuentra mencionado en la tapa de esta sección con el título, "La nueva soja permitirá ahorrar en aplicaciones", que destaca un beneficio económico para los productores.

En el interior del suplemento, se vuelve a titular enfatizando en el beneficio económico que obtendrán los productores que utilicen el nuevo producto: "La nueva soja que permite ahorrar hasta tres aplicaciones de insecticidas".

La volanta indica que la nueva semilla es producto de la "Biotecnología". Por su parte, la bajada hace hincapié en que ya se está sembrando con Intacta RR2 Pro en dos países de Sudamérica y que la semillera Nidera organizó una visita al país fronterizo para recorrer los lotes sembrados con los nuevos productos transgénicos: "La Intacta RR2 de Monsanto ya se produce en la Argentina y Brasil; Nidera mostró a productores y técnicos en el país vecino las características de este material".

Al igual que en la UA 5 y como se verá en el presente análisis, para el diario La Nación los eventos organizados por las empresas que publicitan en sus páginas son noticia; a diferencia del diario Página 12, en donde abordan otros temas referidos a la soja y donde no existen notas de corte instructivo /educativo destinadas a productores rurales. En el discurso que es objeto de este análisis se informa que la compañía organizó "una visita a Brasil con 36 productores argentinos de punta para recorrer los lotes sembrados con estos nuevos materiales transgénicos”.

Teniendo en cuenta el cuadrado ideológico de van Dijk, en el discurso se enfatizan los beneficios de los tres eventos transgénicos para los productores que utilicen la semilla de Monsanto:

- "Con esta triple tecnología transgénica -aseguran las empresas semilleras-, el productor podría ahorrarse hasta tres aplicaciones de insecticida, gracias a la cobertura contra orugas, y aumentar su potencial de rendimiento".

- "Esta tecnología genética consta de tres eventos biotecnológicos en la misma semilla: al conocido RR (resistente a glifosato) -que el 25 de marzo cumplirá 17 años de su aprobación en la Argentina- se le suman el nuevo RR2, que aumentaría un 3 por ciento el potencial de rendimiento, y el BT, que protege a la planta del ataque de hasta cinco tipos de lepidópteros (rachiplusia, pseudoplusia, anticarcia, espilosoma y epinotia)”.

Al enfatizar en los beneficios y características del producto, La Nación intenta persuadir a sus lectores, en calidad de potenciales clientes, para la adquisición de las semillas una vez que sea aprobada por China, principal destino de las exportaciones. 
Continuando con el cuadrado ideológico, el discurso resalta expresiones a favor del pago de un "royalty" por la tecnología aplicada y omite comentarios en su contra, a pesar de lo controvertido del tema y de la existencia de cientos de organizaciones de agricultores familiares que se pronuncian en contra de las regalías a lo largo y ancho de nuestro país. Para el diario de los Mitre, el cobro de un plus por las investigaciones se trata de un tema cerrado que no admite discusión en sus páginas, aunque señalan que aún no se ha fijado el sistema de pago:

- "Otro de los temas importantes que deben formalizarse entre Monsanto, Nidera, Don Mario, los productores y el resto de la cadena productiva es el cobro de las regalías, asunto que todavía no está claro entre los distintos actores”.

- “... se está trabajando para llegar a un acuerdo, pero todavía hay más preguntas que respuestas. Desde hace dos años, Monsanto ya logró acuerdos con más de 800 productores que se comprometieron en el pago de regalías para cuando salga esta nueva soja al mercado. En esos casos el agricultor deberá pagar un royalty por la tecnología nueva (RR2 + BT) que aporta Monsanto, pero además abonar la regalía extendida correspondiente al mejoramiento genético tradicional de los materiales de Nidera y Don Mario, según sea la marca adquirida”.

Tampoco se menciona el aspecto ecológico del tema, en el sentido de que al ahorrar hasta tres aplicaciones de insecticidas se contribuye al cuidado del medio ambiente. Esto hace suponer que para el diario La Nación en esta noticia lo único importante es resaltar el aspecto económico del hecho y persuadir al lector sobre las bondades del nuevo producto y su posterior compra. Para ello utiliza la palabra autorizada de un gerente de Nidera:

- “Todavía no sabemos el precio que tendrá la bolsa, pero la ventaja económica para el productor debería ser mayor respecto del costo de dos aplicaciones de insecticidas, sin tener en cuenta el beneficio del nuevo gen que potencia el rendimiento', explicó Carlos Balbi, gerente de autógamas de Nidera, y aclaró que la venta se realizará, por ahora siempre y cuando llegue la aprobación de China-, sólo en las provincias del Norte (Salta, Tucumán, Chaco, Formosa, Santiago del Estero y norte de Santa Fe), y la primera venta, que serán grupos de variedades 7 y 8 , se hará directamente desde la compañía, en principio a los productores que hayan firmado el acuerdo con Monsanto". 
Por otra parte, el diario informa a sus lectores que la nueva semilla sería lanzada a la venta una vez aprobada por China:

- “... todavía falta un paso fundamental que no depende de lo que decidan las empresas, los productores o el gobierno local: es la aprobación de China, el principal comprador de la soja argentina. Sin la autorización de ese país, no tendría sentido lanzarla comercialmente para esta campaña...”.

De igual modo, menciona las empresas a través de las cuales los productores podrían adquirir las semillas en poco tiempo más:

- "Pero como la empresa norteamericana (por Monsanto) no vende soja en el mercado argentino, la tecnología se incorporará en nuevos materiales locales que deberán tener un potencial de rendimiento superior a los testigos que están actualmente en el mercado, todos desarrollados y seleccionados por las semilleras Nidera y Don Mario, que en abril próximo formalizarían el acuerdo con la compañía norteamericana".

A modo de síntesis y haciendo un repaso de las predicaciones que aparecen en el discurso puede inferirse que la unidad de análisis seleccionada se trata de una "publinota", ya que contiene todos los datos para promocionar la venta de la nueva semilla de Monsanto. Entre otros aspectos señala: por qué comprarla (beneficios), a qué empresas, los productores de qué región geográfica podrán adquirirla, a partir de cuándo se podrá conseguirla y qué deberán pagar los productores.

Por último, la fotografía que acompaña al texto documenta la visita de los productores argentinos a un campo experimental de siembra de la nueva semilla en Brasil.

UA 41. La noticia titulada, "La soja del futuro ya está en el país" se ubica en el suplemento Campo del diario La Nación, en su edición del sábado 30 de marzo de 2013; ocupando el 10\% de la página 7 en su extremo superior. El 90\% restante posee clasificados de venta, compra y alquiler de campos.

La volanta indica el nombre de la variedad de soja a la que alude: "Intacta". Mientras que la bajada menciona a la empresa semillera que realizó ensayos a campo y destaca los atributos de la nueva semilla: "La nueva variedad, presentada por Nidera, asegura más productividad y control de malezas; esperan que se concrete la aprobación de China para liberar su comercialización". 
El discurso trata sobre una presentación de plantaciones de soja que cuenta con tecnología Intacta RR2 Pro, organizada por la firma Nidera en el campo experimental El Recuerdo en la localidad de Venado Tuerto, provincia de Buenos Aires. Evento que según el diario contó con la presencia de numerosos productores y técnicos.

En esta noticia, el diario de los Mitre señala los atributos de la semilla Intacta RR2 Pro; mencionando entre ellos, su rendimiento y resistencia a plagas y malezas:

- “... la tecnología Intacta RR2 Pro, que confiere una mayor productividad al contener la nueva generación del gen RR (RR2Y) para el control de malezas y gracias al gen $\mathrm{Bt}$ permite un control de las principales orugas que atacan el cultivo”.

- "Una característica de los cultivares Intacta de ciclo corto de Nidera es que además casi todos cuentan con la tecnología Ligate STS, de Dupont, que en aplicaciones para barbechos largos controla Rama Negra, entre otras malezas difíciles, explicó Guillermo Marrone de Dupont”.

Como también pudo observarse en la UA 5, los encuentros a campo que realizan las compañías semilleras (Syngenta, Nidera, Don Mario) que publicitan en las páginas de La Nación son hechos noticiables para el diario. Por otra parte, se mencionan los atributos de la nueva semilla de soja con la intención de persuadir a los lectores que pudieran ser productores para que la adquieran. Por otra parte, reproduce la palabra autorizada de Rodolfo Rossi, investigador de Nidera, quien se mostró esperanzado en que las nuevas semillas sean lanzadas comercialmente a la brevedad para su siembra en el norte y centro argentino. Téngase en cuenta que por ese entonces China aún no había aprobado la nueva soja y que el principal destino de la oleaginosa sudamericana es el mencionado país asiático. Por lo que Monsanto aguardaba la liberación comercial de dicha tecnología: "Rossi dijo que se descuenta una rápida adopción en las zonas sojeras del NEA y NOA dado los mayores ataques de lepidópteros en esas regiones. En tanto que en la zona central, donde ese problema es menor o requiere tratamientos que incluyen sólo una aplicación de insecticidas, la mayor inversión que requerirá la siembra de soja estará compensada principalmente por el plus de rendimiento obtenido".

UA 42. La noticia titulada "Un día contra la multinacional" fue publicada en la edición del 23 de mayo de 2013 del diario Página12. Más específicamente en la página 19 del rubro Sociedad. 
La volanta resalta la cantidad de ciudades en donde se llevarán adelante medidas de protesta contra la compañía que lidera el mercado biotecnológico a nivel mundial: "En 300 ciudades marcharán para denunciar el modelo agrario de Monsanto". Mientras que la bajada informa dónde y cuándo se realizarán las medidas de reclamo en nuestro país: "La protesta se llevará a cabo en varias ciudades argentinas entre hoy y el sábado. En Córdoba, los vecinos se oponen a la instalación de una planta de la compañía en la localidad de Malvinas Argentinas y reclaman una consulta".

La noticia anuncia que se realizará una marcha a nivel mundial contra la compañía biotecnológica Monsanto, hecho que es omitido en las páginas del diario La Nación, conforme los criterios de selección de la centenaria publicación.

El discurso emplea como fuentes las declaraciones de activistas ambientales que operan como grupos contrahegemónicos y son introducidas para polemizar sobre el modelo que impulsa Monsanto, brindando información negativa:

- "Monsanto controla el mercado de las semillas, impulsa la aplicación de millones de litros de agrotóxicos, expulsa campesinos, destruye el ambiente y la soberanía alimentaria y daña la salud de miles de personas", denuncia en su comunicado la Asamblea por un Río Cuarto Sin Agrotóxicos".

- "Vanina Barboza Vaca, de la Asamblea de Malvinas, recordó que la localidad es una ciudad 'cercada' por las fumigaciones, donde se repiten abortos espontáneos, malformaciones, cáncer y enfermedades respiratorias. `Decimos no a Monsanto porque ya conocemos los males del modelo que representa. También sabemos que son mentiras sus promesas de trabajo y rechazamos que en nuestro barrio instalen 200 silos de semillas transgénicas tratadas con agrotóxicos', alertó Barboza Vaca".

- "Cristina Arnulphi, docente de la Universidad de Córdoba y militante del Colectivo Paren de Fumigar, recordó que la marcha también es para `decir no a la ley de semillas impuesta por las transnacionales del agro' y advirtió que `el avance de este modelo será a costa de los ecosistemas y a costa de la vida de los campesinos e indígenas'. Y recordó que la soja hoy abarca 20 millones de hectáreas". 
También cita como fuente una encuesta de opinión realizada por las universidades Nacional de Córdoba y Católica de Córdoba y el Conicet, que arroja resultados negativos sobre la construcción de una planta de Monsanto en la localidad de Malvinas Argentinas:

- "En abril pasado, siete investigadores de la Universidad Nacional de Córdoba, la Universidad Católica de Córdoba y del Conicet hicieron pública una encuesta realizada en Malvinas Argentinas: nueve de cada diez (87 por ciento) desean que se realice una consulta popular y el 58 por ciento explicitó que rechaza la instalación de la multinacional. Realizada entre marzo y abril, la consulta se hizo en 352 domicilios a mayores de 18 años. Destaca que el 73 por ciento tiene miedo de opinar en contra de Monsanto por temor a salir perjudicado y el 65 por ciento no tiene confianza en el estudio de impacto ambiental (que realizará la propia empresa bajo la supervisión del gobierno provincial)".

En cuanto a la lexicalización o palabras escogidas para expresar un concepto, en el discurso se denomina "modelo agrario industrial" al sistema productivo impulsado por Monsanto, basado en “agrotóxicos y semillas transgénicas". Como puede observarse, el término empleado para referirse a los agroquímicos posee connotaciones negativas, al evaluarlos como tóxicos.

En base al cuadrado ideológico planteado por van Dijk, el discurso expresa información negativa sobre la empresa Monsanto, que aparece relacionada a la figura del victimario, a través de las siguientes predicaciones: “impulsa la aplicación de millones de litros de agrotóxicos, expulsa campesinos, destruye el ambiente y la soberanía alimentaria y daña la salud de miles de personas" y además comete "excesos contra la naturaleza, los agricultores y los consumidores".

El discurso también predica acerca de la hegemonía de la empresa multinacional: "Monsanto, la corporación líder de agronegocios", “domina el 27 por ciento del mercado de semillas (transgénicas y convencionales) y el 86 por ciento del mercado de transgénicos", "el gigante biotecnológico".

Por su parte, la imagen documenta una protesta realizada a nivel mundial, pero no especifica el lugar. En la misma aparece una cinta de color rojo y letras negras mayúsculas con la siguiente leyenda en inglés: "Monsanto genetic biohazard"; que traducido al castellano significa "Monsanto riesgo biológico genético". 
UA 43. Un año después de haber anunciado que el Gobierno autorizaba el uso de Intacta RR2 Pro, Página 12 informa sobre una presentación judicial que critica el procedimiento de aprobación de la semilla de soja de Monsanto.

La noticia titulada "Una ONG ambientalista objeta una nueva semilla" fue publicada el 5 de septiembre de 2013 en el rubro Sociedad del diario Página 12. Ocupa alrededor del 40\% de la página 18 en su extremo inferior; lo cual indica que el acontecimiento no se encuentra jerarquizado si se lo compara con otras noticias de la misma página.

El título no es puramente informativo y necesita los datos aportados por la volanta para su comprensión: "Presentan una denuncia en la Justicia para la soja de Monsanto". Como puede observarse en los elementos de la titulación se resalta información negativa sobre la mencionada empresa multinacional ya que una organización ambientalista se opone al uso de su nueva semilla de soja.

El discurso elaborado por el periodista Darío Aranda señala en su primer párrafo que, "El Centro de Estudios Legales del Medio Ambiente (Celma) denunció ante la Justicia Federal que es 'irregular' la forma en que fue aprobada la nueva estrella del agro, la semilla de soja Intacta RR2, de la empresa Monsanto”. Puede observarse aquí la existencia de una relación conflictiva entre la mencionada ONG y la compañía biotecnológica internacional y si bien se otorga la palabra a Monsanto para efectuar su descargo (como se verá más adelante), la polémica por el uso de la semilla ingresa a la "arena de los medios" en donde se lucha por la imposición del sentido, a diferencia de La Nación donde el tema es omitido.

La noticia predica información negativa sobre el nuevo producto de Monsanto y sobre los organismos nacionales que aprueban los transgénicos en Argentina, citando como fuente la denuncia Judicial. La denuncia presentada el 19 de marzo de 2013, ante el juez en lo Contencioso y Administrativo, Ernesto Marinelli:

- “Argumentó que en la aprobación no hubo consulta pública, como establece la ley argentina, y que carece del debido estudio de impacto ambiental”.

- “... cuestionó el accionar de los organismos estatales...”.

- “... sostiene que el Estado no realizó estudios...”, “... y que la aprobación `se sustenta en estudios sólo de Monsanto'”. 
- “... sostuvo que se omitió frondosa bibliografía científica sobre los efectos negativos en salud y ambiente de los transgénicos”.

- “... solicita que se anule la aprobación de la soja y se suspenda la comercialización de la semilla".

Página 12 otorga la palabra a un representante de la ONG para comprobar lo que dice al respecto a la acción judicial. Como podrá observarse se trata de citas mixtas en las que se brinda información negativa sobre el procedimiento llevado adelante por organismos estatales:

- "Fernando Cabaleiro, del Celma, cuestionó el rol de la Comisión Nacional de Biotecnología Agropecuaria (Conabia) y del Senasa (Servicio de Sanidad y Calidad Agroalimentaria). `Se basan sólo y exclusivamente en los estudios realizados por la propia firma solicitante, Monsanto. No existe ninguna observación ni pregunta sobre los trabajos presentados por la empresa', afirmó el abogado y señaló que en la foja 37, documento de decisión con el que la Conabia aprobó la nueva soja, se visualizan `once garabatos-firmas, sin aclaración de nombres, especialidad ni cargos. Pudo ser cualquiera. Es insólita la impunidad con la que dan luz verde a una semilla que abarcará millones de hectáreas', cuestionó".

- Cabaleiro "afirmó que es necesario que se reexaminen todas las semillas transgénicas liberadas en Argentina y exigió que `la aprobación no se haga a carpeta cerrada. El procedimiento debe ser transparente y se debe cumplir el requisito de la participación ciudadana para poder realizar las objeciones fundadas que hoy los organismos oficiales ignoran abiertamente'",

De igual manera, Página 12 otorga la palabra institucional a Monsanto que, en su calidad de voz autorizada, defendió la aprobación de la nueva soja:

- "Monsanto señaló en un comunicado que Intacta RR2 se aprobó `cumpliendo con todos y cada uno de los requisitos exigidos por la Resolución 763/11 del Ministerio de Agricultura', que regula la autorización de transgénicos. La empresa valoró la acción de la Conabia y Senasa. El escrito de Monsanto sostiene que 'las normas que regulan el proceso de aprobación no prevén audiencia pública' y afirmó que 'Argentina cuenta con un sistema regulatorio consistente con los estándares internacionales; el principio subyacente 
de la normativa argentina es la seguridad y a tales fines las evaluaciones sólo permiten argumentos científicos, sólidos y estrictos'”.

La nota anexa titulada, "Polémica por un dictamen", acompaña a la noticia principal en un recuadro. La misma adhiere información negativa sobre el Organismo estatal encargado de la Sanidad y Calidad Agroalimentaria en nuestro país, al señalar que, "El Celma cuestionó que en el dictamen aprobatorio, por parte del Senasa, interviniera un científico con 'conflicto de intereses', Moisés Burachik. `Ha sido miembro asesor de una asociación internacional de la cual Monsanto es parte', afirmó el Celma”.

El discurso revela además que, "Burachik es socio honorario de ILSI (Instituto Internacional de Ciencias de la Vida), que tiene entre sus socios directos a las multinacionales de agroquímicos y transgénicos Bayer, Dow Agro Sciences, Syngenta y Monsanto”.

El diario vuelve a otorgar la palabra a Cabaleiro, referente de la ONG, quien emite un juicio de valor negativo sobre los organismos estatales que actúan en la aprobación de los OGM:

- "Los integrantes de la Conabia, Dirección de Biotecnología y Senasa deben ser los expertos por el Estado que deben tener una postura neutra en la aprobación de los organismos vegetales genéticamente modificados. Pero la realidad muestra que están estrechamente vinculados con una organización internacional como ILSI, que en todos sus documentos y actividades surge un claro interés en propugnar una santificación de los transgénicos", denunció el abogado".

UA 44. La noticia titulada "Dos meses de bloqueo" fue publicada en el rubro Sociedad del diario Página 12; en su edición del 23 de noviembre de 2013. Ocupa el 60\% de la página 18 y se sitúa en su costado derecho. Como vimos en la UA 42 y veremos en los sucesivos análisis, Página 12 ubica en este rubro las protestas y denuncias de diferentes poblaciones del país, en contra del modelo productivo agrosojero y sus consecuencias; entre ellas, daños a la salud por fumigaciones, desalojos por el avance de la frontera agropecuaria, asesinato de campesinos, desmonte y contaminación del medio ambiente. En estos casos, se observa que las noticias sobre la soja se desplazan a un sistema de clasificación distinto a los rubros Política y Economía en los que venían apareciendo las UA. 
El título no resulta informativo pero se sustenta de la volanta para comprenderlo: "El rechazo a la planta de Monsanto en Córdoba". Como puede observarse, en este elemento de la titulación se destaca información negativa sobre la compañía multinacional, al señalar que existe resistencia por parte de un sector de la sociedad. Mientras que la bajada resalta que "el reclamo contra la planta de semillas transgénicas en Malvinas Argentinas empezó el 19 de septiembre". Y agrega que, "La empresa envió cartas documento a los protagonistas de la protesta".

Cabe señalar, que las medidas de fuerza implementadas por los vecinos de la mencionada localidad cordobesa no aparecen mencionadas en el diario La Nación; donde se omite cualquier tipo de información negativa sobre la multinacional y sobre este caso particular.

Volviendo al discurso seleccionado, en el primer párrafo se alude a una relación conflictiva entre dos partes, con fuerzas disímiles; por un lado, "Asambleas socioambientales, activistas, organizaciones sociales y vecinos de a pie", y por otro, "la mayor empresa de agronegocios del mundo". Al respecto, señala que los primeros, "lograron lo que pocos creían: frenar a Monsanto" y paralizar, desde hace dos meses, "la construcción de su megaplanta de semillas transgénicas en Córdoba".

Se trata de un discurso de alta referencialidad, donde se brindan detalles precisos sobre la cronología de los hechos y el contexto geográfico del lugar elegido para la instalación de la planta, a fin de que el lector pueda comprender por qué se realiza el bloqueo: "Monsanto anunció en junio de 2012 la construcción de su mayor planta en Latinoamérica de semillas de maíz transgénico. El lugar elegido fue Malvinas Argentinas (Gran Córdoba), ciudad rodeada de soja y con experiencia en fumigaciones sobre viviendas. De inmediato nació la Asamblea de Vecinos Malvinas Lucha por la Vida. Primero exigieron información a la municipalidad y al gobierno provincial. La información nunca llegó. Pero los vecinos comenzaron a realizar asambleas y comunicar quién era Monsanto, qué modelo agropecuario representa, y los propios vecinos comenzaron a informar a sus pares mediante panfletos, charlas debate y murales".

Teniendo en cuenta el cuadrado ideológico propuesto por van Dijk, el discurso enfatiza información negativa sobre Monsanto y sobre el Gobierno provincial de José Manuel de la Sota, al señalar que la empresa incumplió la realización del estudio obligatorio de impacto ambiental, establecido en la Ley General del Ambiente y que el Ejecutivo provincial tampoco se lo exigió. Agrega además, que el intendente Daniel Arzani (UCR) y el gobernador de la Sota (PJ) 
rechazaron la iniciativa de la Asamblea de Vecinos Malvinas Lucha por la Vida, que en noviembre de 2012 comenzó a exigir que la realización de un plebiscito en el que la población pudiera votar a favor o en contra de la instalación.

La noticia señala además, la existencia de sectores de la sociedad que se oponen a la construcción de la planta biotecnológica, lo que puede ser tomado como información negativa para la empresa:

- "Dos encuestas confirmaron el rechazo a la empresa. En abril, investigadores de la Universidad Nacional de Córdoba (UNC), la Universidad Católica y del Conicet realizaron 350 encuestas en Malvinas Argentinas. Nueve de cada diez se mostraron a favor de que se realice una consulta popular en la localidad y el 58 por ciento explicitó que rechaza la instalación. En octubre, la consultora Sicchar difundió una encuesta de opinión de 1000 casos (en capital y el interior). El 63,2 por ciento se mostró en desacuerdo con la planta y el 66,8 por ciento se mostró de acuerdo con los vecinos que se oponen".

- "En las últimas semanas, tres universidades nacionales de Córdoba cuestionaron la instalación de Monsanto. En documentos separados, la Universidad Católica, la de Río Cuarto (UNRC) y la de Córdoba cuestionan que se haya permitido la obra sin la previa Evaluación de Impacto Ambiental, como establece la Ley General del Ambiente, y que tampoco se cumpliera con las audiencias públicas. (...) La UNC ya había cuestionado la llegada de Monsanto en agosto de 2012. Y la UNRC se había expedido también contra la multinacional y el modelo de agronegocios".

El discurso señala además, que en respuesta a las medidas de fuerza implementadas por los activistas, "Monsanto envió cartas documentos a Sofía Gatica (de la organización Madres de Ituzaingó) y a Eduardo Quispe, de la asamblea de Malvinas Argentinas. A ambos los acusó de 'lesionar la seguridad pública' por el bloqueo y denunció supuestos 'actos de violencia contra el personal'". Como puede observarse, el enunciador utiliza comillas para alejarse de las expresiones utilizadas por la empresa.

En cuanto a las fuentes, Página 12 utiliza un comunicado de la Asociación Campesinos del Valle de Conlara de la provincia de San Luis, que rechaza la actividad de Monsanto en el Valle de Conlara, en donde alquilan campos a la empresa Cresud. El documento redactado por familias 
rurales vecinas de la empresa, brinda información negativa sobre la compañía y el modelo agropecuario:

- "Monsanto produce semillas bajo el modelo de la agricultura industrial, desmontaron miles de hectáreas, se siembran cultivos transgénicos de maíz y soja para semilla, se fumiga muchísimas veces durante el ciclo del cultivo con productos altamente peligrosos para la salud, sin el consenso de nuestra comunidad', denunció la Asociación...”.

- 'Los campesinos alertaron que el uso de agroquímicos 'pone en riesgo los acuíferos', reclamaron que se los deje de fumigar en sus casas, exigen un estudio de impacto ambiental y resaltaron: 'Este modelo no genera puestos de trabajo, no genera alimento para nuestra zona y pone en riesgo nuestra salud'”.

La noticia presenta una nota anexa titulada "Amenaza contra una dirigente" que alude a la intimidación recibida por Sofía Gatica, referente de la organización Madres de Ituzaingó y participante del bloqueo contra Monsanto.

El enunciador toma como fuente las declaraciones de Gatica, quien rememora las palabras de la persona que la desafió, y a través de citas mixtas se relata cómo sucedieron los hechos: "Vamos a desparramar tus sesos por Malvinas Argentinas. No jodas más'. Fueron las palabras de un hombre que, arma en mano, amenazó días pasados a Sofía Gatica (...) La amenaza sucedió en Alta Gracia, cuando Gatica iba al trabajo. Un hombre de unos 50 años se acercó y le mostró un arma. 'Hay varias formas de morir', le advirtió".

El discurso señala de manera implícita que, a pesar de los amedrentamientos recibidos por realizar el bloqueo; entre ellos, las acciones legales iniciadas por la multinacional y la amenaza de vida denunciada por una activista, los miembros de la asamblea pudieron suspender la construcción de la obra.

Por otra parte, la fotografía que acompaña a la noticia, documenta una pancarta ubicada frente al predio de la compañía en Malvinas Argentinas que dice, "No a Monsanto en Córdoba y América Latina"; mensaje que expresa una opinión negativa sobre la empresa. Su epígrafe agrega información contextual: "Las protestas contra la instalación empezaron en junio de 2012”. 


\section{II.6. Los silobolsas.}

"El productor agropecuario tiene todo el derecho de vender el producto de su trabajo, de su inversión, en el momento que más crea conveniente y sobre todo es un acto de responsabilidad, con una expectativa de 30 por ciento de inflación, mantenerse en algo que guarde alguna relación con lo que tiene que comprar durante el año".

Luis Miguel Etchevehere, presidente de la Sociedad Rural ${ }^{36}$.

UA 45. La noticia seleccionada se encuentra en el suplemento Cash del diario Página 12, en su edición del 7 de octubre de 2012. Ocupa las páginas 6 y 7 a modo de falsa central y está acompañado del seudorrubro "Finanzas".

El título "Pocos dólares, mucha soja", alude a la paradoja que implica la existencia de escaza cantidad de dólares pese a un elevado stock de soja. Esta figura retórica une ideas contradictorias en un mismo pensamiento. Téngase en cuenta que por aquellos días, la utilización de silobolsas era toda una innovación y que antes de su implementación, los productores culminaban la cosecha y vendían la producción a las cerealeras, lo que implicaba el ingreso de moneda extranjera al país.

La volanta señala la causa que origina el acopio de la producción: "Los productores retienen parte de la cosecha porque no pueden dolarizar ganancias". Nótese, que el diario utiliza el verbo retener que posee connotaciones negativas ya que implica "interrumpir o dificultar el curso normal de algo", según la Real Academia Española. La acción de retener está asociada a la idea de fuerza o presión, a diferencia de los verbos "almacenar", "guardar" y "conservar", utilizados por el diario La Nación en las UA 46 y 47.

La bajada por su parte, informa sobre la cantidad de soja que hasta el momento no fue comercializada y hace alusión a la nueva medida implementada por el ente recaudador del Estado: "La cosecha de soja que todavía no fue vendida en el mercado es de 7 a 8 millones de toneladas, granos que están guardados en silobolsas. A partir de este mes, los productores deberán informar a la AFIP el stock de granos".

\footnotetext{
36 “Para la Sociedad Rural, la soja está bien guardada”. Página 12, 31 de marzo de 2013.
} 
En el primer párrafo del discurso se describe el efecto económico que tuvo para nuestro país la utilización de silobolsas; aludiéndose a la existencia de una alteración en el modo de reponer las reservas que el Banco Central utilizaba para el pago de la deuda externa:

- "Pese a pronósticos de cosecha récord y precios de granos en máximos históricos, el Banco Central no está sumando reservas. El pago de deuda con reservas tiene implícito el objetivo de recuperarlas rápidamente y hasta superar el monto previo al desembolso. Los silobolsas alteraron esa estrategia al diluir los límites de la estacionalidad en la venta de granos y posterior liquidación de divisas por parte de los exportadores. Un trimestre después de finalizada la cosecha de soja, resta ingresar al mercado de siete a ocho millones de toneladas".

A lo largo del discurso, existen marcas que revelan la postura del enunciador respecto a los productores que retienen soja en silobolsas. Por ejemplo, utiliza el recurso de la ironía a través del entrecomillado para dar a entender lo contrario de lo que se dice acerca de las "necesidades" de los ruralistas:

"El fuerte crecimiento económico de zonas sojeras tiene su origen en la decisión de los productores de volcar parte de su renta anual en la compra de activos muebles e inmuebles. Luego de la crisis 2001-2002, los empresarios del campo se alejaron de los bancos, comprando propiedades y vehículos $4 \mathrm{x} 4$. También invirtieron en instalaciones y maquinaria. Cubiertas esas "necesidades", el excedente comenzó a dolarizarse". En este ejemplo puede observarse que, a diferencia del diario La Nación, no se victimiza al sector agropecuario. Al contrario, se hace alusión a la compra de bienes que no son indispensables o básicos y se menciona la capacidad de ahorro.

El discurso advierte la verdadera intención de los ruralistas que guardan la producción: "Los productores no esperan mejores precios, sino que especulan con que se relajen los controles oficiales o encontrar algún artificio legal que les permita volver a atesorar dólares. En este caso, los silobolsas, un invento argentino que es aprovechado por sólo cuatro firmas que además exportan a casi todos los países productores de granos, se convierten en cajas fuertes de lo que consideran un bien que puede liquidarse fácilmente". En este extracto aparecen subjetivemas que desacreditan la actitud de los ruralistas, a quienes asocia con el deseo de guardar dólares como un tesoro. Y, por otra parte, compara a los silobolsas con cajas fuertes. 
El discurso también explica que los silobolsas son utilizados porque las cerealeras pagan precios bajos por la producción local pese a las buenas cotizaciones internacionales. Y, agrega una expresión de uso popular para describir que pocas empresas se concentran la exportación: "La menor liquidación también responde a la tensión entre los exportadores y los productores por los menores precios que pagan los primeros respecto de la cotización internacional. Esto es posible porque la intermediación se concentra en pocas manos".

La noticia emplea como fuentes a la Consultora Investigaciones Económicas Sectoriales y a la Bolsa de Cereales de Buenos Aires para probar la idea central del discurso, que señala que pese a los pronósticos récord de cosecha y granos, la producción no se está comercializando. Según la clasificación propuesta por Lucrecia Escudero, se trata de fuentes textuales institucionales oficiales:

- "Según un informe de la consultora Investigaciones Económicas Sectoriales, la cosecha finalizará en 107 millones de toneladas, si 'persisten las favorables condiciones climáticas'. El informe sostiene que las exportaciones agrícolas de este año sumaron 21.105 millones de dólares, con una caída de 6,2 por ciento, mientras que, con 89,3 millones de toneladas, experimentó una pérdida del 13,6 por ciento respecto de la campaña pasada, 2010-2011”.

- "Por otra parte, según estimaciones de la Bolsa de Cereales de Buenos Aires, la próxima cosecha de soja - para el cierre de la actual campaña-- podría alcanzar un nivel record de 19,7 millones de hectáreas, cifra que sería un 4,5 por ciento superior a la registrada en 2010-2011. Esta previsión se sustenta en el interés que despierta el buen nivel de precios internacionales, actualmente en torno de los 570 dólares -tras tocar un techo de 650 la tonelada-, en detrimento del maíz".

Por otra parte, el discurso señala que, "En el Gobierno estudian cómo incentivar a productores de soja para que liquiden los granos guardados en silobolsas"; a diferencia del diario La Nación para quien el Gobierno "presiona" a los productores para que liquiden. Como puede observarse, estos diarios dan versiones totalmente opuestas sobre el accionar del Gobierno. Mientras Página 12 predica de manera positiva, La Nación asocia al Gobierno con el uso de la fuerza.

Otro tema que se aborda es la nueva Resolución de la AFIP que señala la obligatoriedad de informar el stock de granos y la cantidad de hectáreas sembradas: "A partir de este mes, la AFIP 
contará con información del stock y de las hectáreas sembradas, que se irá informando a medida que se levante la producción de trigo, maíz, soja y girasol. Deberá informarse el stock de todos los granos y las hectáreas sembradas durante el mes de octubre y, en caso de que no se cumpla esta obligación, podría haber sanciones, según la resolución publicada a mediados de septiembre. La información incluye también las tenencias en silobolsas, tanto en campos propios como prestados, lo que permitirá tener un control sobre el remanente que quede por liquidarse en el mercado".

La imagen que acompaña al texto, se clasifica como documental, ya que intenta probar la utilización de silobolsas en los campos. Su epígrafe agrega un dato sobre estimaciones de la siguiente cosecha: "La próxima cosecha de soja podría alcanzar un nivel récord de 19,7 millones de hectáreas".

UA 46. La noticia que es objeto de este análisis fue publicada en la edición del 2 de mayo de 2013 del diario La Nación. Se ubica en el rubro Economía y ocupa alrededor de un 25\% de la página 19, sobre la línea de indicatividad. Como ya se señaló en otras unidades de análisis, para este periódico la soja es un tema netamente productivo y por lo tanto, se sitúa en el espacio destinado a la economía.

Desde el título, el diario instaura de manera implícita la sospecha de que el Gobierno podría tener algo que ver con los daños a silobolsas, como método de presión para que se comercialice el producto: "Atacan silos bolsas y temen que sea para que el campo venda soja”. Nótese además, que emplea la estrategia de superficie de la generalización para mencionar al campo como un bloque homogéneo.

La volanta menciona a la localidad en donde se produjo el hecho: "9 de Julio". Mientras que la bajada hace referencia al productor afectado, la cantidad de bolsas dañadas y advierte que los ruralistas se encuentran intranquilos: “Al productor Walter Paganti le cortaron ocho bolsas donde almacenaba granos; preocupación entre ruralistas de la zona”.

El discurso trata sobre el ataque a ocho silobolsas en las que un productor de la localidad bonaerense de 9 de Julio almacenaba soja y manifiesta que los pobladores de la zona temen que se trate de un mensaje para los que guardan la cosecha, como señala en su primer párrafo: “... en 
esa zona se encendió el temor a que se trate de una advertencia hacia aquellos que no venden el grano".

De manera latente, se instaura la idea de que el Gobierno podría estar relacionado con el hecho; para ello, utiliza la palabra autorizada de Walter Paganti, el productor afectado y de Nicolás Capriroli, presidente de la Sociedad Rural de la mencionada localidad, a modo de citas prueba:

- "Paganti sostiene que no tiene conflictos ni con empleados ni con centros de transportistas de cereales como para sospechar de algo que haya provocado ese ataque. Tampoco recibió amenazas previas. En rigor, quienes cometieron el hecho no destruyeron ni robaron ninguna otra cosa del lugar, donde hay una oficina y camiones para el transporte de granos. 'No robaron nada en la oficina ni en los camiones', señaló”.

- “No sabemos si es un hecho aislado o algo más complejo por la soja', indicó a LA NACION".

- "Antes de una entrevista telefónica con este cronista, el productor ya había advertido mediante un mensaje privado en la red Twitter que esperaba que el hecho no fuera una 'persecución por no vender la soja'”".

- "El productor hizo la denuncia ante la comisaría local y avisó a otros productores de la región para que estén alertas. 'Ojalá que sea aislado y esto no empiece como en 2008 [el año del conflicto con el Gobierno por las retenciones móviles], cuando cortaban las bolsas', dijo".

- 'Nicolás Capriroli, presidente de la entidad, expresó: `Es preocupante. Esperamos que no sea un ataque a la forma de comercialización'”.

- "Capriroli afirmó que los productores tienen 'la libertad de vender según las circunstancias'. En este sentido, consideró que almacenar el grano es 'una manera de resguardar el capital'".

El último párrafo de la noticia refuerza la idea implícita de que el Gobierno podría tener algo que ver con los ataques, al señalar que necesita dólares: "Con inspecciones de la AFIP sobre el sector en plena cosecha en los campos, el Gobierno procura que los productores vendan la soja para hacerse de los dólares que necesita".

Al igual que en otras unidades de análisis, el diario La Nación victimiza a los ruralistas, a quienes asocia con los siguientes léxicos: ataque, temor, preocupación y alerta. 
Por otra parte, la fotografía que acompaña a la noticia retrata, como señala su epígrafe, "uno de los ocho bolsones rotos que guardaban soja". Se trata de una imagen documental que intenta probar la realidad del hecho.

UA 47. La noticia seleccionada fue publicada en la edición del 3 de mayo de 2013 del diario La Nación. Se encuentra ubicada en el rubro Economía y ocupa el 25\% de la página 14, sobre la línea de "indicatividad", rodeada de avisos de remates judiciales y de clasificados. Cabe señalar, que este hecho no aparece mencionado en el diario Página 12, lo cual indica que los criterios de selección de ambos diarios son diferentes y operan conforme al público al que se quiere llegar.

En el título: "La Rural ve la mano del Gobierno en el ataque a silos bolsas con soja" pueden observarse dos estrategias discursivas. Por un lado, se emplea una metáfora para responsabilizar al Gobierno de la rotura de bolsones que contenían granos. Este recurso es utilizado para dar énfasis a lo que se está diciendo y para llamar la atención del lector. Según van Dijk, la métafora puede emplearse para subrayar "nuestras" cualidades y "sus" defectos. Y por otra parte, aparece una relación de oposición entre dos actores, la Sociedad Rural Argentina (SRA) y el Gobierno Nacional.

La volanta, conformada por la expresión "Rechazo" hace referencia al repudio de la patronal. Y, la bajada reproduce una acusación del líder de la SRA contra el Gobierno: "Según Luis Etchevehere, presidente de la entidad, el corte a las instalaciones de un productor está 'en la misma línea' de otras ofensivas de la Casa Rosada contra el sector”.

El discurso que nos ocupa es una repercusión de la embestida a ocho silobolsas con soja en la localidad bonaerense de 9 de Julio, hecho que fuera anunciado por el centenario periódico en la noticia titulada "Atacan silos bolsas y temen que sea para que el campo venda soja" (UA 46).

En esta ocasión, se informa sobre el pronunciamiento en contra del principal representante de la SRA, tomando como fuentes otros medios de comunicación: "Entre quienes repudiaron el hecho, que en la madrugada del martes afectó al productor Walter Paganti, estuvo el presidente de la Sociedad Rural Argentina (SRA), Luis Miguel Etchevehere. El dirigente señaló, en declaraciones a las radios Eı Mundo y Colonia, que esa acción podría estar 'en la misma línea' de la ofensiva oficial contra el campo que mantiene el Gobierno". 
El diario reproduce, a través de citas directas, opiniones de Etchevehere en las que 1) descalifica las políticas llevadas adelante por el Gobierno de Cristina Kirchner y 2) defiende intereses de grupo:

1) "Con este gobierno estamos acostumbrados a no creer en las coincidencias. Si miramos para atrás, vemos que hay señales muy fuertes y que ésta podría ser otra en la misma línea del intento de confiscación del predio de la Sociedad Rural en Palermo, la quita del formulario 1116 a Federación Agraria Argentina [lo emitía esa entidad para el depósito de granos], el apriete por parte de la AFIP a productores agropecuarios para que vendan la cosecha vieja a quienes conservaban algo, el Proyecto $\mathrm{X}$ que mostraba que se habrían realizado escuchas telefónicas a dirigentes ruralistas y de la Mesa de Enlace, y la amenaza de aplicar la ley antiterrorista a quienes no vendan soja', expresó el ruralista".

2) "Ante el descalabro que hay en la economía, el productor sabe que una tonelada de soja le alcanza para tanto de fumigación, herbicida, fertilizante. Vender toda la soja al momento de la cosecha y ver cómo esos pesos obtenidos se devalúan a lo largo del año es suicida', subrayó el presidente de la Sociedad Rural Argentina".

Por otra parte, en el cuerpo de la noticia aparecen, en un tamaño de letra mayor y en negritas, los siguientes destacados:

- "Productores en máxima alerta. Temor por los ataques contra la soja almacenada".

- "Vender toda la soja al momento de la cosecha y ver cómo esos pesos obtenidos se devalúan es suicida".

Este recurso, utilizado en los diferentes géneros periodísticos, actúa como elemento que sirve para aligerar la lectura y poner de relieve núcleos centrales de la información. En el primero de los casos, se describe una situación que podría tener un impacto persuasivo en muchos lectores que se dediquen a la producción de soja, poniéndolos en vilo ante un eventual ataque. Mientras que el segundo destacado reproduce la opinión de Etchevehere, que evalúa como poco rentable comercializar la cosecha debido a la inflación.

En cuanto a la fotografía, se trata de una imagen documental en la que aparece el rostro del líder de la SRA; cuyo epígrafe señala: "Luis M. Etchevehere, Pte. Sociedad Rural Argentina". 


\title{
II.7. Los costos sociales del modelo agrosojero.
}

\footnotetext{
"Sosegao vivia en mi rancho como el pájaro en su nido; alli mis hijos queridos iban creciendo á mi lao... Solo queda al desgraciao lamentar el bien perdido". José Hernández ${ }^{37}$.
}

\begin{abstract}
"Cuando a un campesino le sacan la tierra, es como si lo mataran. ¿A dónde va a ir con su mujer y sus hijos? ¿Qué hará con los chivos, las ovejas, las gallinas? ¿A caso puede llevar esa vida a la ciudad? Yo, que ya tengo el segundo desalojo, se lo he dicho bien claro a mi señora: si nos vienen a desalojar, yo no me he de ir nunca. A mi del campo me sacan muerto". Ignacio Avellanal, dirigente de la Asamblea Campesina e Indígena del Norte Argentino ${ }^{38}$.
\end{abstract}

UA 48. El diario Página 12 publica en su edición del 14 de agosto de 2012 la noticia titulada, "Avance sojero", que ocupa un 30\% de la página 17 en el rubro Sociedad. En ella, el periodista Darío Aranda denuncia las consecuencias sociales del modelo agrosojero. Cabe señalar que notas similares a esta y redactadas por el mismo reportero, ocupan de tres a cuatro páginas en la revista "MU" y son anunciadas en sus tapas. Por el espacio que ocupa el acontecimiento en Página 12 y su ubicación debajo de la línea de "indicatividad", se infiere que no se trata de uno de los hechos principales de la edición; no obstante, el diario hace visible las consecuencias del avance del monocultivo; a diferencia de La Nación en cuyas páginas ni siquiera aparecen mencionadas.

El diario titula enunciando una situación y la volanta, "Desalojo y retenciones" anticipa los efectos de quienes resisten la expansión de la frontera agropecuaria.

La noticia reproduce una denuncia de la comunidad Indio Calalao reprimida por la Policía de Tucumán para ser desalojados del territorio que habitan desde el año 1600. El pueblo originario aparece asociado a la idea de víctima debido a que un grupo de empresarios pretende sembrar soja.

Teniendo en cuenta las estrategias de fondo planteadas por Prieto Castillo, el discurso describe una relación de oposición entre víctima y victimarios; entre los miembros de la comunidad

\footnotetext{
37 "Martín Fierro" (2009:17).

${ }^{38}$ En Acción, revista de INCUPO, Agosto/Septiembre de 2014, página 5.
} 
originaria y la Policía/el Gobierno/los empresarios/el modelo sojero y la Justicia; como puede observarse en el siguiente mapa de predicaciones:

\begin{tabular}{|c|c|}
\hline $\begin{array}{l}\text { Comunidad } \\
\text { Indio Calalao }\end{array}$ & $\begin{array}{l}\text { “...sufrió dos represiones de la policía para ser desalojados del } \\
\text { territorio que habitan desde el } 1600 " \text { " } \\
\text { “... enfrentaron } 25 \text { pedidos de detención por no acatar el desalojo } \\
\text { y dos miembros de la comunidad estuvieron apresados durante doce } \\
\text { días". } \\
\text { "Desde la década del ' } 90 \text { mantienen conflictos con privados que } \\
\text { pretenden } 19 \text { mil hectáreas para agricultura. Enfrentaron desde } \\
\text { amenazas y matanza de animales hasta contaminación de pozos } \\
\text { de agua e intentos de desalojos". }\end{array}$ \\
\hline Empresarios & $\begin{array}{l}\text { "En septiembre de 2010, el empresario Freddy Moreno Núñez Vela } \\
\text { cerró el único camino vecinal que permitía el ingreso de vehículos". }\end{array}$ \\
\hline Policía & $\begin{array}{l}\text { "E1 } 23 \text { de junio, la policía provincial allanó la comunidad indígena } \\
\text { por orden de la jueza Ema de Nucci y a pedido del fiscal Guillermo } \\
\text { Herrera". } \\
\text { "Luego de las } 15 \text { comenzaron la represión y el desalojo. Hubo } \\
\text { balas de goma, corridas y palazos policiales". }\end{array}$ \\
\hline Justicia & $\begin{array}{l}\text { "E1 } 25 \text { de julio, el fiscal Guillermo Herrera solicitó la detención de } \\
25 \text { integrantes de la comunidad. El juez Pisa apoyó el pedido del } \\
\text { fiscal. La acusación: 'Tentativa de homicidio, lesiones, robo, } \\
\text { amenazas y otros'". }\end{array}$ \\
\hline Gobierno & $\begin{array}{l}\text { No da respuestas sobre el desalojo al comunero Elías Apaza, de } 90 \\
\text { años y no vidente. }\end{array}$ \\
\hline
\end{tabular}


Por otra parte, la palabra del "otro" se inserta a través de citas directas que buscan producir un efecto de realidad. Según Sandra Savoini (2004), la palabra ajena puede ser introducida para expresar lo que piensa quien redacta el texto. Esto podría ocurrir en el discurso que es objeto de nuestro análisis, teniendo en cuenta las predicaciones analizadas anteriormente y que el primer párrafo de la noticia comienza con una cita que condena el procedimiento llevado adelante por la Justicia y el Estado: “El genocidio del general Roca continúa hoy en Tucumán', denunció la comunidad Indio Colalao, del norte provincial...”. Con esta declaración, los hechos de represión y desalojos en Tucumán quedan asociados a la expresión negativa "genocidio".

En esta unidad de análisis, se otorga la palabra a la vocera de la comunidad Indio Colalao y a la ONG Abogados del Nordeste Argentino en Derechos Humanos, para repudiar la represión policial:

- “Jueces y políticos violan nuestros derechos y sólo benefician a los que tienen dinero', acusó Cynthia Ovejero, vocera de la comunidad".

- “La ONG Abogados del Noroeste Argentino en Derechos Humanos denunció la “criminalización de la lucha indígena en Tucumán'. Cuestionó al fiscal Herrera y a los jueces Nucci y Pisa. 'La bochornosa actuación de la Justicia tucumana sigue dando muestras de cuán vulnerables pueden ser los principios del debido proceso', explicó la directora, Josefina Doz Costa".

- 'La comunidad indígena de Colalao alertó que los pueblos originarios de Tucumán están padeciendo una 'cacería que recuerda el genocidio de Julio Argentino Roca en la Campaña del Desierto'. La vocera Cynthia Ovejero adelantó qué hará la comunidad: 'Seguiremos peleando por nuestros territorios'”.

Por otra parte, se utiliza como fuente un documento de Amnistía Internacional que contiene una advertencia al Gobierno Nacional:

- “Amnistía Internacional Argentina acaba de solicitar al gobierno nacional que 'respete los derechos humanos' de los pueblos originarios. 'El Gobierno debe poner fin a los desalojos que se llevan adelante en distintas provincias y entregar los títulos de propiedad comunitaria de las tierras ancestrales', reclamó. Citó como casos emblemáticos de expulsión de comunidades y 'violenta represión estatal' a las provincias de Formosa, Neuquén, Salta y Tucumán”. 
En esta UA pudo observarse que Página 12 hace visible los reclamos de pueblos originarios; es decir, de otros sectores que integran el campo argentino y que aparecen en menor medida en los grandes medios de información que centran su atención en las patronales defensoras del agronegocio. Este diario de alcance nacional, hace visible la existencia de represiones y encarcelamientos por parte de la Policía de la provincia de Tucumán a raíz de órdenes de desalojos judiciales. Y, hace visible también diferentes ataques sufridos por la comunidad por parte de empresarios privados, como ser la matanza de animales y la contaminación de pozos de agua. Temas que no aparecen en las páginas de La Nación, para quien la idea de víctimas gira en torno a los agroexportadores que se encuentran en "crisis" debido a las políticas económicas implementadas por el Gobierno de Cristina Kirchner.

UA 49. La noticia titulada "Denuncian el asesinato de un campesino" se encuentra publicada en la edición del jueves 12 de octubre de 2012 del diario La Nación, en el rubro Seguridad. La misma ocupa alrededor del $8 \%$ de la página 29 , en su extremo inferior; lo que indica la escasa jerarquización del acontecimiento si se compara con el espacio asignado a otras noticias en el mismo rubro.

Las 16 líneas que ocupa la noticia anuncian el asesinato de Miguel Galván, un campesino del Paraje Simbol de Santiago del Estero. El diario de los Mitre no volverá a mencionar el caso en otras ediciones, tampoco informará sobre las marchas organizadas en repudio del hecho ni se lo citará como antecedente de violencia en sucesos que ocurrieron con posterioridad por problemas de tierras.

Además, puede observarse que La Nación construye el acontecimiento como un hecho más de inseguridad en nuestro país, por eso se lo ubica en el rubro Seguridad junto a otros asesinatos y problemas delictivos. El centenario diario reduce el hecho a una cuestión delictiva sin explicar el contexto de lucha por las tierras en el que se produjo ni el corrimiento de la frontera agropecuaria.

El discurso toma como fuente un comunicado del Movimiento Nacional Campesino Indígena que "denunció el asesinato de uno de sus integrantes". A diferencia del discurso de Página 12, la palabra ajena se otorga a través de citas indirectas; es decir, modificando la narración de los acontecimientos. No aparecen citas directas en donde los referentes del movimiento realicen 
juicios de valor expresando su repudio al asesinato y tampoco aparece la palabra de gobernantes locales o nacionales refiriéndose al hecho.

La noticia señala como causa del crimen el desmonte realizado en la zona: "En el comunicado de ese movimiento se afirmó que el crimen tuvo que ver con las denuncias efectuadas en los últimos meses sobre la tala indiscriminada que realizan empresas en la zona norte de Santiago del Estero", pero a diferencia de la UA 50, perteneciente a Página 12, no relaciona el hecho con el avance de la frontera agropecuaria debido a los cultivos extensivos; entre ellos, la soja, ni alude a la falta de títulos de propiedad de las tierras. Tampoco menciona que Galván ya había sufrido amenazas ni que existieron otros asesinatos por las tierras que habitan los campesinos hace más de 20 años y también son reclamadas por los empresarios. La noticia se presenta sin datos contextuales por lo que se trata de un discurso de baja referencialidad; estrategia de fondo del discurso planteada por Prieto Castillo para señalar que la versión ofrece unas pocas palabras sobre algo, con la intención de que con ellas se agote todo.

Por otra parte, señala que el Movimiento Campesino "acusó a empresas agropecuarias instaladas en el norte de Santiago del Estero como promotoras del ataque”, sin ahondar en la búsqueda del autor del hecho y en las hipótesis del asesinato. Solamente agrega la versión que señala el comunicado sobre cómo se produjo el asesinato: "Según manifestaron los miembros de esa organización, Miguel Galván recibió un mortal cuchillazo en el cuello en el Paraje Simbol”.

Otra diferencia con el diario Página 12 es, como veremos a continuación, que en este discurso los campesinos no aparecen como víctimas o afectados.

UA 50. En esta unidad de análisis, el diario Página 12 informa sobre hechos de violencia contra sectores que conforman el campo argentino y no se encuentran representados por la Mesa de Enlace. El discurso seleccionado se encuentra en la edición del 16 de octubre de 2012, ocupando un $70 \%$ de la página 18 del rubro Sociedad. El 30\% restante se encuentra ocupado por otra noticia que posee estrecha relación con la primera y que forma parte de la UA 53. Si bien el acontecimiento no aparece mencionado en la tapa, el espacio que se le dedica es una manera de jerarquizarlo; teniendo en cuenta que la publicación analiza en profundidad 4 o 5 hechos destacados por jornada, en 32 o 40 páginas, según la edición. 
El título "Denuncias de violencia contra campesinos", categoriza a los pobladores afectados por los conflictos de tenencia de tierras como "campesinos" y se los asocia con la idea de ser víctimas que padecen hechos de violencia. La volanta resalta el reclamo principal de los campesinos: "Organizaciones sociales reclaman al gobierno que regularice la posesión de tierras", pero no especifica si aluden al ejecutivo provincial o al nacional.

La bajada señala, "En Santiago del Estero, el crimen de Galván fue una etapa de una escalada originada por la extensión de la frontera agrícola. Organizaciones rurales reclaman al gobierno provincial que cumpla con la regularización de tierras". El discurso categoriza como "crimen" a la muerte de un campesino; palabra que posee connotaciones negativas ya que está ligada a la idea de un delito, de un culpable, de un victimario y una víctima. Nótese cómo desde los elementos de la titulación el medio adopta una postura negativa sobre la expansión de la frontera agropecuaria, situación a la que señala como el génesis de la violencia.

"El asesinato el miércoles pasado del campesino indígena Miguel Galván descubrió una vez más la escalada de violencia que sufren las comunidades campesinas e indígenas de Santiago del Estero", señala el primer párrafo del discurso. En este fragmento se informa sobre el asesinato de un campesino de apellido Galván que fue apuñalado al resistirse a abandonar la tierra donde vivía. Desde el inicio de la noticia puede observarse que los campesinos están asociados a la idea de víctimas que "sufren" nuevamente una "escalada de violencia".

De igual manera, se subrayan propiedades negativas de empresarios interesados en las tierras, que actúan con el respaldo de jueces y policías: "Represión, amenazas, desalojos, causas armadas, detenciones arbitrarias, golpizas e intentos de homicidio son sólo algunas de las prácticas de amedrentamiento utilizadas por empresarios en complicidad con jueces y policías provinciales". En el discurso se explica que estas formas de atemorizar tienen su origen en el "boom de la soja". A diferencia de la noticia del diario La Nación sobre el mismo tema (UA 49), donde se omiten explicaciones sobre el contexto en el que se produjo el asesinato de Galván.

Al igual que en la UA 48, el diario Página 12 alude a la existencia del corrimiento de la frontera agropecuaria por la siembra de soja; tema denunciado de manera recurrente por las organizaciones ambientalistas, como lo hemos explicado en el inicio de esta investigación. De igual modo, señala que el modelo agrosojero es el origen o causa de la violencia ejercida contra 
los campesinos. A diferencia del diario La Nación que asocia la muerte de Galván con un hecho más de violencia en nuestro país y lo ubica en el rubro Seguridad.

Por otra parte, el discurso reproduce los reclamos de los campesinos hacia el Gobierno de Santiago del Estero: "Desde el Movimiento Campesino de Santiago del Estero (Mocase) exigen que el gobierno local aplique una política de inversión para los pequeños productores y que cumpla con los programas de regularización de la posesión de tierras".

En este discurso, los pobladores que reclaman la tenencia de tierras aparecen caracterizados como "campesinos indígenas", "comunidades campesinas", "comunidades rurales e indígenas" y "pueblo indígena"; respetando la auto denominación de dichas comunidades santiagueñas. El hecho de mencionarlos así y no utilizar denominaciones como "pueblos originarios", "productores" o "ruralistas" indica cierta cercanía con el sector. Por su parte, el accionar de los campesinos es categorizado como "lucha en defensa de la tierra" y "lucha por conservar la tierra".

Página 12 califica a los conflictos de la zona como graves y a los asesinatos como trágicos. Mediante estos evaluativos axiológicos el sujeto enunciador manifiesta un juicio de valor negativo acerca de la situación:

- "El asesinato de Ferreyra, el 16 de noviembre de 2011, evidenció la gravedad de los conflictos en la zona".

- "No fue el único caso que casi termina en tragedia".

Por otra parte, la noticia señala de manera implícita 1) que la muerte de Galván podría haberse evitado de haber intervenido la Policía y la Justicia y 2) que los problemas de tierra no son algo nuevo sino que provienen de años atrás:

1) “Galván había denunciado en varias oportunidades amenazas de muerte, intentos de desalojo y golpizas por parte de grupos armados que intentaban echarlos de su comunidad".

2) "El ataque se produjo en el paraje Simbol, del departamento de Copo, el mismo donde fuera asesinado hace menos de once meses el campesino indígena Cristian Ferreyra también en el marco de su lucha en defensa de la tierra-, y tuvo lugar a pesar de que la familia de Galván había denunciado en varias oportunidades amenazas de muerte, intentos de desalojo y golpizas por parte de grupos armados que intentaban echarlos de su 
comunidad (...) El $1^{\circ}$ de julio, por ejemplo, Sixto Ruiz, un campesino también del distrito de Copo, fue baleado en su estancia por un grupo armado de alambradores que intentaba echarlo de su tierra. La bala le atravesó el pecho a un centímetro del corazón. Ruiz sobrevivió. No fue el único caso que casi terminó en tragedia. El 19 de diciembre de 2011, Néstor Palacios 'recibió un disparo cuando defendía los territorios de su comunidad frente al avance de los alambradores custodiados por una banda armada", acusó el Mocase-VC'",

En el discurso existen dos marcas puntuales que señalan el posicionamiento del enunciador sobre el hecho; por un lado, relaciona de manera directa el asesinato de Galván con la figura de un empresario agropecuario y con la expansión de la frontera agropecuaria; basándose en una denuncia del Movimiento Campesino de Santiago del Estero (Mocase). Y, por otra parte, mediante el uso del pronombre posesivo "su", manifiesta que las tierras pertenecen a los campesinos:

- “Galván, campesino del pueblo indígena lule-vilela, de 40 años, murió el miércoles tras ser apuñalado en la yugular por un hombre que responde a un empresario agropecuario salteño".

- "El $1^{\circ}$ de julio, por ejemplo, Sixto Ruiz, un campesino también del distrito de Copo, fue baleado en su estancia por un grupo armado de alambradores que intentaba echarlo de su tierra. La bala le atravesó el pecho a un centímetro del corazón. Ruiz sobrevivió".

La evaluación o postura del diario sobre el tema puede observarse además, en el análisis de las fuentes. Se introducen citas directas que brindan información negativa sobre el gobernador de Santiago del Estero y el Poder Judicial, a quienes responsabiliza de la situación de violencia que existe en la provincia.

- "Era una muerte anunciada. Hace rato que los movimientos campesinos denunciamos que esto pasaría otra vez. El gobernador Gerardo Zamora y el Poder Judicial de la provincia son los responsables de las condiciones de violencia e indefensión en que se encuentran las comunidades rurales e indígenas. Siguen privilegiando la producción de soja por sobre los derechos de los campesinos que llevamos generaciones trabajando la tierra', denunció Roger Almaraz, vocero del Mocase. En el caso de Galván, cuenta, ya 
habían intervenido el Comité de Emergencia, que depende de la gobernación y, por lo tanto, el crimen 'debía haberse evitado'”.

La palabra "ajena" es introducida para denunciar y repudiar hechos de violencia, no existen opiniones que posean una orientación diferente. Tampoco aparecen descargos del Gobierno provincial o de los empresarios que exigen sus tierras. La voz autorizada es la de los campesinos. Esto es a lo que Prieto Castillo denomina "uniacentualidad significativa”, recurso utilizado para dejar una sola versión del tema.

Por otra parte, la imagen que acompaña a la noticia es documental. La misma retrata una marcha de distintas organizaciones sociales en repudio a los desalojos y la represión policial. El epígrafe señala que el crecimiento de la soja es la causa de la violencia: "Las organizaciones denuncian que el problema recrudeció con el boom de la soja”.

UA 51. La unidad de análisis seleccionada se ubica en la edición del 16 de octubre de 2012 del diario Página 12. Ocupa un 30\% de la página 18 en el rubro Sociedad, debajo de la UA 50; con la cual se relaciona de manera temática.

Su título, "Un intento para frenar los ataques", enuncia una situación, más que anunciar un hecho pero se apoya en la volanta para hacer comprensible el acontecimiento: "Proyecto para suspender desalojos por cinco años". Como puede observarse, la idea de violencia ejercida contra un grupo se encuentra expresada desde el titular, con el léxico "ataques", que posee connotaciones negativas.

La noticia anuncia la conferencia de prensa que realizará el Movimiento Nacional Campesino Indígena (MNCI) "junto a un grupo de legisladores del Frente para la Victoria (FpV), donde hablarán de los alcances de un proyecto de ley que declara la emergencia en materia de posesión y propiedad de las tierras rurales". Cabe señalar que la conferencia de prensa y el proyecto para frenar los desalojos no aparecen mencionados en el matutino de los Mitre.

El discurso que nos atañe señala que el principal objetivo de la norma es "frenar por cinco años los desalojos de campesinos que se ven afectados por el corrimiento de la frontera agrícola a partir de los agronegocios". En este fragmento se emplea el evaluativo axiológico "afectados" que denota un juicio de valor negativo del sujeto enunciador y una toma de posición respecto al sujeto denotado. Al utilizar este adjetivo subjetivo se pone de manifiesto que los campesinos 
padecen o están perjudicados por el avance de la frontera agrícola. De igual modo, Página 12 vuelve a relacionar de manera directa el desalojo de los campesinos con el agronegocio, situación que no ocurre en el diario La Nación.

En la noticia se alude que dicho proyecto fue elaborado por "organizaciones campesinas y presentado el año pasado por el diputado Edgardo Depetri, pero acaba de cobrar un nuevo impulso político tras el asesinato de Miguel Galván, en Santiago del Estero”. En este fragmento puede observarse que Página 12 vuelve a mencionar al igual que en la UA 50, el crimen del campesino Galván; hecho que solamente es mencionado en un pequeño espacio del diario La Nación, el 11 de octubre de 2012, en su página 29; como vimos en la UA 49.

En el discurso aparece también la figura retórica de la paradoja, para señalar que los desalojos se producen a pesar de la existencia de una ley que avala el derecho de la posesión de tierras, en caso de habitarla por 20 años: "Con el auge de los agronegocios, muchos campesinos sufrieron desalojos de sus tierras, más allá de estar amparados por la ley veinteañal, que indica que si una persona o familia habita por más de veinte años un campo para su subsistencia, tiene derecho de posesión sobre el mismo". Este fragmento señala de manera implícita que los desalojos son ilegales, por contradecir una norma que ampara el uso de las tierras por parte de los campesinos. De igual manera, relaciona otra vez el desalojo con los agronegocios. Y, finalmente, a través del adjetivo posesivo "sus" hace explícita la idea de que las tierras pertenecen a los campesinos y no a los empresarios que impulsan los desalojos, al señalar que "los campesinos sufrieron desalojos de sus tierras".

En cuanto a la polifonía de voces, en el discurso se otorga la palabra a Leonardo Grosso, diputado Nacional por Buenos Aires del Frente para la Victoria, que en su calidad de voz autorizada y a través de citas directas brinda información positiva sobre el proyecto:

- "La ley sirve como una herramienta legal para que las provincias puedan administrar los conflictos que tienen', indicó a Página/12 Leonardo Grosso (FpV), del Movimiento Evita, la misma fuerza política a la que pertenece Pérsico”.

- "Grosso indicó a este diario que el impulso a este proyecto se basa en 'la necesidad de construir una salida política (al conflicto de tierras) con una mayor participación del Estado nacional'". 
También toma como fuente el proyecto de ley para suspender los desalojos por cinco años y cita considerandos, en los que alude a la necesidad de su implementación a fin de proteger derechos humanos y sociales de los campesinos:

- "Se propicia esta ley de emergencia como remedio a los innumerables conflictos por la tenencia de las tierras rurales que son causa de una vulneración sistemática de los derechos humanos de estas familias campesinas en tanto son desalojadas y desapropiadas de sus pertenencias', puede leerse en los fundamentos del proyecto".

- “Una ley que suspenda los desalojos confiere también la expresión la tierra para quien la trabaja y una protección de los derechos sociales, como el derecho al trabajo', sostiene la iniciativa bajo análisis".

- “El eje que seguimos en torno de la alta conflictividad que existe sobre la tenencia de las tierras comunitarias está vertebrado por la relación entre legalidad y legitimidad, que se relaciona con la coexistencia de dos modelos de desarrollo antagónicos: los agronegocios y el modelo de producción campesina', explica la iniciativa".

UA 52. La noticia titulada "Reclamos del otro campo" fue publicada en la edición del 17 de abril de 2014 en el diario Página 12. Ocupa el 60\% de la página 16 del rubro Sociedad. La cantidad de espacio que utiliza en tres de las cinco columnas de la página, el empleo de todos los elementos de titulación y de una fotografía, indican la jerarquización del hecho en esta publicación de alcance nacional.

Página 12 titula de manera informal, apelando al "efecto de reconocimiento" que plantea Verón; por el cual, en el título se emplea una expresión existente dentro del campo cultural del lector. El periódico denomina el "otro campo" al sector rural que se contrapone a la Mesa de Enlace y al modelo de los agronegocios; es decir, hace referencia a los campesinos o sectores populares del campo, en complicidad con el lector, que sabe a lo que se refiere el diario.

La volanta manifiesta que los reclamos se producen en el marco del "Día Mundial de la Lucha Campesina”. Mientras que la bajada aporta datos contextuales para la comprensión del título y señala dos pilares de la lucha campesina que no aparecen mencionados en las unidades de análisis del diario La Nación: "Diversas organizaciones presentarán hoy sus demandas al conmemorarse una jornada que busca defender las semillas criollas y avanzar hacia la soberanía alimentaria”. 
Las semillas criollas hacen referencia a semillas autóctonas, adaptadas al entorno por un proceso de selección natural o manual por parte de los agricultores. "La utilización de semillas criollas se ha ido reemplazando por variedades muy homogéneas que no son naturales, sino que han sido obtenidas artificialmente, como son las semillas comerciales (híbridos y transgénicos), utilizadas para la siembra de grandes extensiones, por ejemplo la soja en nuestro país", señala un folleto sobre Semillas Nativas y Criollas del Ministerio de Agricultura, Ganadería y Pesca de la Nación y de la Federación de Organizaciones Nucleadas de la Agricultura Familiar (FONAF).

Mientras que la soberanía alimentaria se define como "el derecho de los pueblos a la producción de alimentos sanos y nutritivos, producidos en forma sustentable y ecológica, accesibles y culturalmente adecuados. Postula la libre decisión de los pueblos sobre cómo organizar la producción y el sistema alimentario poniendo en el centro de escena a quienes producen, consumen y distribuyen los alimentos por encima de las exigencias del mercado", señala la revista Agricultura Familiar de la FONAF (2013: 13).

La noticia elaborada por el periodista Darío Aranda, hace referencia a las movilizaciones y asambleas que se llevarán a cabo en el marco del Día Mundial de la Lucha Campesina. Actividades convocadas en defensa de las semillas criollas y de la soberanía alimentaria. Y, también, para reclamar por la pérdida de estado parlamentario del proyecto de ley para frenar los desalojos campesinos y por las fumigaciones de agroquímicos sobre viviendas. Temas que como ya se dijo no son mencionados en las unidades de análisis de La Nación.

Página 12 otorga la palabra a referentes de organizaciones campesinas que se pronuncian a favor de las semillas criollas y en contra de las semillas transgénicas, el agronegocio, los desalojos a campesinos y las fumigaciones sobre viviendas habitadas:

- Diego Montón, del Movimiento Campesino Indígena (MNCI) "alertó por un proyecto de ley de semillas impulsado por Monsanto y resaltó que `el extractivismo no posibilita ningún proyecto nacional ni latinoamericano'”.

- "Nahuel Levaggi, de la Unión de Trabajadores de la Tierra (UTT), evaluó que la 'correlación de fuerzas es muy desigual' entre el agronegocio y el campesinado, afirmó que 'el único que puede equilibrar esa balanza es el Estado' y se animó a la autocrítica: 'Tenemos que elaborar propuestas, presionar arriba para poder plasmarlas y evitar la fragmentación del campo popular'”. 
- “... en lo que va de 2014, los campesinos sufrieron cuatro fumigaciones. 'Hicimos las denuncias y ahí estamos, resistiendo', señaló Goyo Arias, de la Asociación Campesina del Valle de Conlara. Recordó que en la zona están presentes Cresud, Monsanto y pooles de siembra que inundan los campos con soja y maíz transgénico”.

Como puede observarse, la palabra ajena pertenece a referentes "del otro campo" que operan como voz autorizada en la defensa de sus derechos, y no se acude a informantes de las instituciones que conforman la Mesa de Enlace, fuentes comúnmente utilizadas por el diario La Nación.

La palabra ajena también es utilizada para describir de manera negativa a los Poderes Ejecutivo y Legislativo en lo que respecta a su "falta de apoyo" a los sectores populares del campo:

- "La caja del Ministerio de Agricultura sigue siendo para el agronegocio. Y las monedas para agricultura familiar', cuestionó José Luis Castillo de la Asamblea Campesina Indígena del Norte (Acina)”.

- “El agronegocio avanza y no tenemos apoyo real de provincia ni de Nación', resumió Raúl Galván, de la Coordinadora de Organizaciones Campesinas Indígenas y Trabajadores Rurales (Cocitra). (...) Cuestionó al Poder Legislativo: ‘Pasaron años y ni leyeron el proyecto de ley para frenar los desalojos. No les importamos'. Reveló que sólo se financian proyectos a 'organizaciones paraestatales, oficialistas'”.

También se utiliza como fuentes un comunicado de la organización internacional Vía Campesina en el cual se defiende el uso de semillas criollas y datos del Ministerio de Agricultura para abrir la polémica:

- "Las semillas tienen un lugar fundamental en la lucha por la soberanía alimentaria. De ellas depende el alimento de los pueblos, cómo se cultiva y quién lo cultiva', explica el llamamiento de la Vía Campesina, que nuclea organizaciones de 70 países y denuncia la 'privatización' de las semillas que impulsan las grandes empresas”.

- “El Ministerio de Agricultura reveló en 2013 que hay un piso de 9,3 millones de hectáreas en disputa y 64.000 familias campesinas e indígenas afectadas”.

La noticia está acompañada por una nota anexa titulada, "Aquella matanza en el Amazonas", en donde se explica porqué se conmemora cada 17 de abril el Día de la Lucha Campesina. Allí señala que, "El 17 de abril de 1996, en el estado amazónico de Pará (Brasil), el Movimiento de 
Trabajadores Rurales sin Tierra bloqueó una ruta en reclamo de la reforma agraria. La policía asesinó a 21 campesinos e hirió a 69. La organización denunció que la represión estuvo orquestada por autoridades políticas, la policía, el ejército y grandes terratenientes".

Por otra parte, la noticia presenta una fotografía que documenta a un grupo de campesinos sosteniendo un pasacalle, cuyo epígrafe señala, "Las organizaciones de base denuncian el avance del agronegocio".

En este discurso, el campo de lexemas relacionados con el agronegocio es el siguiente: "privatización de las semillas", "grandes empresas", "Monsanto", "extractivismo", "desalojos", "fumigaciones", "pooles de siembra", "soja y maíz transgénicos", "asesinato" y "poderosos". Mientras que los léxicos relacionados a los campesinos son: "semillas criollas", "soberanía alimentaria", "afectados", "reflexión, unión y lucha", "trabajo conjunto de organizaciones campesinas", "agricultura familiar", "resistiendo", "reforma agraria", "producción agroecológica" y "alimentos sanos". A partir de estos términos puede observarse que para Página 12, en el campo coexisten dos economías; el modelo del agronegocio y el de la agricultura familiar, este último omitido en las unidades de análisis del diario La Nación. 


\section{II.8. La tala de árboles.}

"Entre 2004-2012 las topadoras arrasaron 2.501.912 hectáreas, el equivalente a 124 veces la superficie de la ciudad de Buenos Aires".

Darío Aranda, revista $\mathrm{MU}^{39}$.

"La destrucción de los bosques de nuestro país se realiza por el avance de la frontera agropecuaria, principalmente para cultivos de soja y afecta de manera directa a la población campesina e indígena, las más olvidadas. La desaparición de los bosques favorece la pérdida de todo tipo de vida y aumenta la posibilidad de que muchas zonas se conviertan en desiertos". Mocase, revista Defensa del Monte ${ }^{40}$.

UA 53. El presente discurso fue publicado en la edición del 12 de noviembre de 2012 del diario Página 12. Se ubica en el rubro Sociedad y ocupa alrededor del 55\% de la página 14 . El espacio que utiliza, su ubicación sobre la línea de indicatividad, el titular desplegado a modo "bandera" y la incorporación de una imagen para ilustrar el texto, indican que se trata de la noticia más importante de la página.

La noticia denuncia, como señala su título, el "Desmonte en zonas prohibidas" en la provincia de Salta. Para ello, toma como fuente el informe de situación denominado "Vulneración a los derechos de pobladores criollos e indígenas por deslindes y desmontes irregulares", realizado por la Defensoría del Pueblo de la Nación. Cabe destacar que, desde el titular se señala la ilegalidad de la tala, al calificar las zonas como "prohibidas".

En la noticia se plantea que el avance de la soja y el corrimiento de la frontera agropecuaria actúan como causa de los desmontes:

- “(La región visitada) se encuentra sometida a una alta presión desmontadora impulsada por los altos valores de la soja, que han empujado a la ganadería fuera de las zonas centrales de la Argentina desplazándola hacia el gran Chaco argentino, y por lo tanto también a Salta. Estos cambios atentan directamente contra el sistema tradicional de producción ganadera del criollo chaqueño', afirma la Defensoría, que recorrió doce comunidades".

\footnotetext{
${ }^{39}$ Edición de marzo de 2013; página 18.

${ }^{40}$ Número1; página 14.
} 
Como se señaló anteriormente, la principal fuente del discurso es el informe de la Defensoría del Pueblo, que en la clasificación propuesta por Lucrecia Escudero forma parte de las fuentes textuales institucionales oficiales. Dicho documento opera como fuente autorizada que resalta información negativa sobre el avance de la frontera agrícola:

- "El corrimiento de la frontera agropecuaria implica la violación de derechos de campesinos y comunidades indígenas. Lo afirmó la Defensoría del Pueblo de la Nación en su último informe sobre la situación rural en el nordeste de Salta, donde constató desmontes en zonas prohibidas, violencia sobre comunidades, incumplimiento de leyes nacionales y provinciales, falta de control por parte del gobierno provincial y la ausencia del Instituto Nacional de Asuntos Indígenas (INAI)".

En cuanto a las proposiciones que plantea van Dijk, los campesinos y comunidades indígenas son considerados víctimas, teniendo en cuenta que están amparados por la ley para habitar los territorios que ocupan pero sus derechos son quebrantados: "Se ha verificado una clara vulneración a los derechos de pobladores criollos e indígenas, un potencial daño al medio ambiente, debilidad en el accionar de la provincia para la solución de los hechos observados y la existencia de un conflicto social latente, que demanda la urgente atención por parte de todas las autoridades con el fin de evitar una escalada que produzca consecuencias imposibles de remediar', alertó la Defensoría del Pueblo".

Para reforzar la idea de víctima, que aparece implícita en el discurso, se menciona la existencia de "tres leyes (dos nacionales y una provincial) que protegen a las comunidades pero no se cumplen":

- "La ley 26.160 (sancionada en 2006) suspende los desalojos y ordena realizar un relevamiento catastral de comunidades. 'El fracaso del relevamiento es tal que implicó la anulación en 2011 del convenio entre INAI y el Instituto Provincial de Pueblos Indígenas de Salta (Ippis), por el que se financiaba al equipo de técnicos que efectuaría el relevamiento. Apenas una decena de carpetas había sido presentada', detalla".

- "La Ley Provincial 7658 es similar a la 26.160, pero para criollos de Salta. Suspende los desalojos y prevé la realización de un censo de campesinos. `El relevamiento nunca se realizó, por lo que la situación no pasó de ser una expresión de deseos', cuestiona la Defensoría”. 
- 'La ley 26.331, conocida como 'ley de bosques', establecía un reordenamiento territorial que identificara las zonas de monte en tres colores: rojo (no se puede desmontar), amarillo (requiere autorizaciones para realizar actividades intensivas) y verde (se puede desmontar). Las comunidades visitadas están ubicadas en zonas rojas y amarillas”.

El discurso predica sobre el "'proceso de arrinconamiento' que padecen las comunidades mediante el cercado de fincas vecinas que limitan los espacios de ganadería de criollos e indígenas". El verbo "padecer" es sinónimo de sufrir o soportar y es un léxico que posee connotaciones negativas que sitúa a las comunidades en el lugar de víctimas.

La palabra "ajena", a través del discurso directo de Horacio Esber, director de Derechos Sociales de la Defensoría, es utilizada para desacreditar el accionar de los gobiernos locales en lo referido a los derechos de campesinos y comunidades indígenas:

- "Los estados provinciales, por acción u omisión, están ausentes en lo que respecta a los derechos de campesinos y comunidades indígenas, y dejan amplias regiones libres al accionar de empresarios y particulares que violan toda la legislación que protege a los sectores más vulnerables del campo".

También se otorga la palabra a un representante de la Federación Wichí con fines polémicos; ya que en sus declaraciones señala que a pesar del informe elaborado por la Defensoría del Pueblo no mejoró la situación de la comunidad: “Estamos igual que cuando vino la Defensoría. Los empresarios nos encierran, voltean los quebrachales y los palo santo, y se nos vienen con las topadoras encima', explicó Ramón Paz, de la Federación Wichí de la cuenca del río Bermejo. Afirmó que la provincia 'siempre promete (mejoras) pero nunca cumple', advirtió que ya no recurren al INAI 'porque siempre nos quieren manejar' y pidió dejar clara la posición wichí y criolla: 'Siempre trabajamos acá, no nos van a correr, tenemos derecho a vivir donde nacimos'”. La imagen posee un uso documental que retrata un campo cuyos árboles fueron cortados y los utilitarios que se emplean para la tala; entre ellos, una topadora, un camión y una camioneta. $\mathrm{Su}$ epígrafe señala: "Vista aérea del desmonte en la reserva de la biosfera de las yungas".

UA 54. La noticia titulada, "Las imágenes del desmonte" fue publicada en la edición del 20 de agosto de 2013 en el diario Página 12. Se sitúa en el rubro Universidad, por informar acerca de un proyecto impulsado desde el ámbito académico, y ocupa alrededor del 70\% de la página 14 . 
La cantidad de espacio que utiliza, los elementos de la titulación extendidos en cuatro de las cinco columnas de la página y el empleo de una imagen para acompañar el texto, son indicios de que el diario jerarquiza el acontecimiento.

Como en otras unidades de análisis, el título de Página 12 no resulta informativo, sino que enuncia una situación y se apoya en los demás elementos de la titulación para su comprensión. El diario busca atrapar al lector e invitarlo a seguir leyendo la noticia, de ahí la utilización de títulos que tienen que ver más con semanarios.

La volanta agrega datos de los responsables del emprendimiento "El trabajo de la Facultad de Agronomía junto a comunidades wichí” y recién en la bajada se explica de qué se trata el proyecto y cuál es su objetivo: "En Salta, docentes y alumnos de Agronomía (UBA) desarrollan junto con pueblos originarios un sistema de monitoreo para detectar la deforestación en tiempo real. 'Queremos contribuir a que las cosas ocurran de una manera menos injusta', dijo el profesor José Paruelo".

El discurso informa sobre el desarrollo de un sistema de monitoreo para detectar la deforestación en tiempo real, a través de imágenes satelitales y "que pueda ser gestionado por las propias comunidades afectadas". En el proyecto trabajan docentes, investigadores y estudiantes de la Facultad de Agronomía de la UBA junto a comunidades wichí de la provincia de Salta, “con el objetivo de frenar los desmontes ilegales en la zona".

En este discurso de Página 12 se visibiliza la deforestación debido al avance de la frontera agropecuaria y se brindan datos al respecto: "La región del Chaco semiárido, que involucra, además del este de Salta, a las provincias del Chaco y Santiago del Estero, concentra el 90 por ciento de la deforestación total del país, y es una de las zonas más afectadas de toda Latinoamérica".

El discurso hace foco en la ilegalidad del desmonte por producirse en áreas protegidas por ley en la provincia de Salta y en que ocurre como consecuencia del avance de la frontera agropecuaria:

- "El trabajo comenzó en el este de Salta luego de la sanción de la Ley de Bosques, en 2008. Ese año la Corte Suprema de Justicia prohibió los desmontes en cuatro departamentos salteños (San Martín, Orán, Rivadavia y Santa Victoria) debido a una presentación de los pobladores, ya que allí se estaban registrando las tasas de desmontes 
más altas de la historia argentina. Según datos oficiales, a fines de los '70 Salta ya había perdido el 25 por ciento de sus bosques nativos, producto de la expansión de la frontera agrícola, lo que afectó a pueblos originarios y criollos. (...)Aunque la ley fue sancionada, los desmontes siguieron".

Teniendo en cuenta el uso de subjetivemas, pudo observarse que en el discurso aparece en reiteradas ocasiones el adjetivo afectivo "afectadas" para caracterizar a las poblaciones rurales que padecen los efectos de las deforestaciones. A partir del empleo de este adjetivo subjetivo se induce que los pobladores son considerados víctimas:

- "El trabajo comenzó con visitas a las comunidades afectadas...".

- "Las comunidades afectadas denuncian que las autoridades no hacen nada para frenar el desmonte".

- “... para implementar un sistema de monitoreo que detecte la deforestación en tiempo real y que pueda ser gestionado por las propias comunidades afectadas".

En cuanto a la polifonía de voces en el discurso, se otorga la palabra a José Paruelo, director de la carrera de Ciencias Ambientales, que en su calidad de voz autorizada expresa información negativa sobre la expansión de la frontera agropecuaria y de la soja. Y, por otra parte, presenta a los pobladores rurales como víctimas del sistema productivo: "En buena parte del norte argentino se está produciendo desde hace diez años una muy fuerte expansión de la agricultura y de la ganadería -afirmó Paruelo-. Para eso es necesario desmontar el bosque original y en ese desmonte aparecen una serie de consecuencias. Los pueblos originarios y criollos son corridos y eso genera desarraigo y migración a periferias urbanas. Si no se van, quedan en una pequeña isla de monte y eso genera consecuencias serias en cuanto a las posibilidades de supervivencia, porque los recursos que utilizaban ya no están más, por el contexto socioeconómico que implica la expansión de las actividades agrícolas, entre ellas la expansión de la soja".

También se toma como fuente a la Red Agroforestal Chaco Argentina (Redaf) para reproducir un fragmento de una entrevista realizada a Félix Jonathan, miembro de la comunidad wichí de General Ballivián, en el departamento salteño de San Martín. El poblador relata sobre lo que significa el monte para las personas que lo habitan, con lo cual refuerza la idea de víctimas, $\mathrm{y}$ denuncia que las autoridades de las fuerzas armadas no interceden para frenar el desmonte ilegal: "Nosotros vivimos del monte. En el monte vamos a campear, a hacer la recolección de alimentos. 
Para nosotros el monte todavía existe porque ésa es nuestra cultura. No vamos a hacer desaparecer las cosas que siempre han sido nuestras. Pero nadie, ni la policía ni gendarmería, se quiere ocupar de lo que aquí sucede. Nadie interviene y, si lo hacemos nosotros, quedamos como los malos. Acá no se está respetando nada. Todos saben que el desmonte está prohibido", dijo en una entrevista con la Redaf. "No es que nosotros queremos olvidarnos de lo que somos, sino que nos destruyen lo que nos pertenece. Queremos mantener nuestra cultura y nuestras costumbres y nos hacen quedar como los malos.”

La noticia presenta una caricatura que según la clasificación de Thibault Laulan posee un uso apelativo, en donde la imagen está volcada a quien la percibe y los elementos se combinan con el fin de impactar o involucrar al perceptor. En la misma aparecen dos personajes, un hombre de edad avanzada vestido con traje y un joven con atuendo informal. El primero señala, "Sí... Estamos desmontando miles de hectáreas para plantar soja y venderla". El joven pregunta, "Y cuando, como consecuencia del desmonte, llegue la sequía. ¿Qué va a vender?”. “¡Pantalla solar!!”, le responde el anciano.

Este dibujo de Daniel Paz ironiza sobre los intereses económicos de los grandes agricultores, que sólo se preocupan por la comercialización de la soja sin pensar en los perjuicios que ocasiona al medio ambiente la deforestación. Y, por sobre todas las cosas, presenta a los grandes agricultores como inversores que están atentos a las circunstancias para llevar adelante un negocio. Como puede observarse, se trata de una imagen editorial, en la que el medio hace visible su opinión sobre el tema.

UA 55. "Desarrollaron un sitio para monitorear los desmontes" tituló el diario La Nación, el 30 de julio de 2014; 11 meses después de que Página 12 haya anunciado dicho proyecto, como lo vimos en la UA 54. La noticia se ubica en el extremo inferior derecho de la página 15, perteneciente al rubro Economía, y ocupa alrededor del 10\% de su espacio; lo que indica la escasa jerarquización del acontecimiento. A diferencia del tabloide que le otorga el $70 \%$ de su página 14 perteneciente al rubro Universidad.

El discurso trata sobre el desarrollo de un sitio de Internet, creado por La Facultad de Agronomía de la UBA (Fauba), el INTA y la Red Agroforestal Chaco Argentina (Redaf), para brindar información actualizada sobre los desmontes ocurridos en la región del Gran Chaco. 
Se trata de una de las dos noticias halladas durante el periodo de estudio en las que el diario La Nación relaciona la deforestación con el avance de la frontera agropecuaria, principalmente por plantaciones de soja: "En la región del Gran Chaco, las tasas de deforestación se encuentran entre las más altas del mundo y están promovidas principalmente por el avance de la frontera agropecuaria en la Argentina, Paraguay y en Bolivia”.

Según la clasificación de Lucrecia Escudero, se utiliza una fuente textual institucional oficial, que brinda detalles del emprendimiento, en su calidad de voz autorizada:

"Desarrollamos un sistema de información geográfica online, de acceso público a través de monitoreodesmonte.com.ar, con mapas interactivos que permiten obtener información actualizada sobre la superficie desmontada desde 1976 y hasta la fecha, a nivel de departamento, provincia o lote", afirmó Federico Pagnanini, del Laboratorio de Análisis Regional y Teledetección, que comparten la Fauba y el Conicet. Añadió: "El reemplazo de bosques por cultivos extensivos, principalmente soja, y por pasturas ya afectó el 20,7\% del área natural de toda la ecorregión Gran Chaco, con 15,8 millones de hectáreas desmontadas hasta fines de 2012". El discurso señala de manera implícita que en la provincia de Salta se realizaron desmontes ilegales: "a fines de 2012, la Fauba y la Redaf advirtieron sobre el aumento de la problemática en Salta, donde detectaron 100.000 hectáreas desmontadas en zonas protegidas por la ley de ordenamiento territorial de bosques nativos. Ahora se están relevando los datos de 2013 para integrarlos al sistema de información geográfica".

Finalmente, puede observarse que se trata de un discurso de baja referencialidad; clasificación elaborada por Prieto Castillo para señalar que una versión ofrece unas pocas notas de algo, con la intención de que con ellas se agote todo. 


\section{9. La contaminación del medio ambiente.}

"En un análisis desde la ecología política llama la atención la permanencia de un patrón fuertemente primarizado donde la Naturaleza queda relegada a un papel subsidiario como proveedora de recursos". Eduardo Gudynas, secretario del Centro Latino Americano de Ecología Social (CLAES) ${ }^{41}$.

"La soja, en tanto monocultivo, opera bajo las mismas lógicas extractivas y de comercialización que la minería y los hidrocarburos".

Sergio Federovisky, biólogo y periodista, profesor de Política Ambiental en la Universidad Torcuato Di Tella ${ }^{42}$.

UA 56. La noticia titulada "El delta del Paraná se está volviendo ingobernable" es el único discurso publicado por el diario La Nación en el periodo comprendido entre agosto de 2012 y julio de 2014 que se relaciona con el eje temático número 9 "La contaminación del medio ambiente"; creado por la autora del presente trabajo para brindar un panorama completo del objeto de estudio. Cabe señalar que en el diario Página 12 no se encontraron noticias que se relacionen de manera exclusiva con este eje. El tema de la contaminación aparece mencionado en las UA 57, 58, 59 y 60 pero desde un enfoque sanitario en los seres humanos, sin profundizar en los efectos que provoca el mal uso de agroquímicos en el suelo, el agua y el aire. Lo que indica que en el periodo de tiempo señalado, los diarios no enfatizaron en esta temática, a diferencia de otras más desarrolladas que requirieron de la selección de noticias por parte de la investigadora para formar parte de la muestra.

El discurso de La Nación fue publicado en el suplemento Campo, el 1 de junio de 2013 y ocupa alrededor del 75\% de la página 6. Su ubicación en el extremo superior de la página, la cantidad de espacio que ocupa y la utilización de tres fotografías a color y dos destacados periodísticos indican que el medio jerarquiza el acontecimiento.

\footnotetext{
41 “Más allá del nuevo extractivismo: transiciones sostenibles y alternativas al desarrollo", Oxfam y CIDES UMSA, La Paz, Bolivia, 2011.

${ }^{42}$ En "La Soja como problema", Le Monde diplomatique, Mayo de 2014. Pág. 9.
} 
El título, "El delta del Paraná se está volviendo ingobernable”, señala una apreciación negativa del enunciador respecto del mencionado territorio. Por sí solo no brinda elementos suficientes para la comprensión del tema, por lo que se sustenta en la volanta (A) y en la bajada (B) que aportan datos sobre la situación del humedal:

A) "Inundaciones $\mid$ Falta un plan hidráulico integral". En este elemento de titulación se advierte la necesidad de una estrategia para revertir la situación descripta.

B) "Los murallones y canales, creados para urbanizaciones y la siembra de soja, son un laberinto infranqueable cuando el río crece”. Mientras que la bajada asocia al cultivo de la oleaginosa con un problema ambiental.

La noticia denuncia que las construcciones urbanas y las plantaciones de soja provocan inundaciones en el Delta del Paraná y explica además, que el uso de herbicidas contamina el humedal; ecosistema considerado como reservorio de agua dulce para las poblaciones cercanas. Junto a la UA 55, son las únicas notas del diario La Nación en las que se mencionan efectos negativos del monocultivo extensivo; en los demás discursos que integran el corpus se brinda información positiva sobre la oleaginosa.

El discurso intenta persuadir a los lectores y convencerlos acerca de la necesidad de la creación e implementación de un plan hidráulico en el Delta: "Preocupa la falta de regulaciones, controles y de un plan integral del manejo del agua. Así, las islas pierden esa suerte de efecto 'esponja', de su capacidad regulatoria, a costa de esos verdaderos murallones levantados para emprendimientos inmobiliarios o agrarios: antes hubiese sido impensado sembrar soja en medio de un humedal". De igual modo, brinda una versión de alta referencialidad mediante una adecuada cantidad de información y detalles precisos que explican por qué se producen las inundaciones, como puede observarse en los siguientes ejemplos:

- "El delta del Paraná se está convirtiendo en un laberinto infranqueable que crea una suerte de tapón fluvial, inundando a las islas y costas desprotegidas a causa de los 'endicamientos', albardones y canales artificiales en un total de 1,7 millones de hectáreas".

- "Se estima que la soja ya cubre casi unas 50.000 hectáreas de esas tierras, con un 25 por ciento de canales artificiales. Las aguas corren río abajo y las crecientes suben. Que el 
agua corra por la pendiente es natural, pero que el flujo se vuelva indomable pasa por otro lugar".

La noticia utiliza fuentes textuales institucionales oficiales pertenecientes a expertos en el tema y a personajes del ámbito político y social. La palabra del "otro" se inserta a través de citas directas e indirectas, en función de la persona que habla y como prueba de lo que señala el enunciador. En las siguientes declaraciones se destaca la importancia que posee el humedal para evitar inundaciones y se intenta crear conciencia en los lectores acerca del impacto negativo que tiene en la flora y fauna autóctonas, la utilización de modelos productivos diseñados para tierra firme, citando el caso de la soja:

- “Quintana (presidente de la Fundación Humedales) resume los servicios ecológicos del humedal: 'Tiene la capacidad de regular los excedentes hídricos amortiguando inundaciones de grandes ciudades e industrias a la vera del Paraná ante la fuerza de semejante volumen de agua. Es que cerca del 96 por ciento de la superficie del Delta tiene una cobertura vegetal herbácea, alta, densa y continua (juncales, pajonales, pastizales y praderas de hierbas hidrófilas), con tallos y hojas flexibles que minimizan la presión del agua sobre las plantas y reducen el flujo dentro del humedal. Así se retarda la descarga de agua dulce al mar y disminuye su impacto sobre las costas'”.

- "Coincide con Quintana, Pedro del Piero, presidente de la Fundación Metropolitana. 'Nuestra mayor preocupación es que se convierta al Delta en continente y por eso insistimos en que no se debe violentar su condición de territorio insular. Se debe permitir que el agua fluya, suba y baje con mareas, crecientes y bajantes. Si se impidiera esta vida, si se rellenan los corazones de islas y se levantan los bordes (albardones) para que el agua no entre se mata el humedal y toda la biodiversidad'".

- "Para la diputada nacional del Pro Cornelia Schmidt Liermann, el tema ambiental es una preocupación permanente: 'De continuarse con la incorporación de técnicas productivas diseñadas para tierra firme en el Humedal Delta, -lo que conlleva a su destrucción- los impactos serán los siguientes: 1) Residuos de agroquímicos. Al utilizar el paquete tecnológico de la siembra directa, es inevitable que los residuos de los agroquímicos aplicados deriven con el impacto inmediato sobre la flora y faunas autóctonas y la permanencia de los mismos en el agua potabilizada para consumo 
humano. Su uso es ilegal, ya que, según las mismas empresas de agroquímicos, no existe un solo producto registrado para ser utilizado en un humedal'".

- "La falta de un plan hídrico integral contrapone y superpone las obras realizadas por el Estado como por los privados, las que se afectan entre sí y producen un gasto ineficiente de ambos recursos', sostiene Cadoppi (presidente de la Sociedad Rural de Ibicuy, Entre Ríos). `Se trata de no seguir el camino de convertir a todo el país en una gran pampa seca sembrada sólo de soja y comunidades cerradas', concluye".

En este discurso, la producción de soja es considerada de manera negativa como un "problema" para el humedal, como puede observarse en el siguiente fragmento: "Las inundaciones no son el único problema que aqueja al gran Delta. A esto se suma el cambio de terrenos (rellenos altos) para la siembra de soja. Es decir, pérdida del humedal y la contaminación de los herbicidas que, finalmente, escurren hacia las napas, es decir hacia el mismo río".

La noticia está acompañada con una fotografía que ilustra el humedal y según la clasificación de Laulan, posee un uso documental. Mientras que su epígrafe realiza un juicio de valor, al aludir de manera implícita que en vez de plantaciones de soja y construcciones debería existir la biodiversidad autóctona: “Como debiera ser: vacas, pajonales, juncales y depresión del suelo; un reservorio de agua en los humedales".

Otro recurso gráfico empleado por el diario La Nación para llamar la atención del lector y resaltar información, es el destacado periodístico que contiene las declaraciones de personajes del ámbito social junto a sus fotografías. Este elemento de lectura rápida se ubica en el cuerpo de la noticia y sirve para aligerar la lectura y poner de relieve núcleos centrales de la información. En la noticia que nos ocupa, el destacado aparece con el título "Voces Calificadas" y enfatiza la palabra de Armando Cadoppi, presidente de la Sociedad Rural de Ibicuy (1); Rubén Quintana, presidente de la Fundación Humedales (2) y Pedro del Piero, presidente de la Fundación Metropolitana (3):

(1) "Nos encontramos en el umbral de lo que puede ser una transformación irreversible por la falta de un plan hídrico integral".

(2) "El humedal tiene la capacidad de regular los excedentes hídricos amortiguando las inundaciones de las grandes ciudades costeras".

(3) "Se debe permitir que el agua fluya, suba y baje con las mareas. Si no entra en las islas, se mata el humedal y toda la biodiversidad que contiene". 
Como puede observarse, estas declaraciones resaltan la importancia del humedal para evitar inundaciones e intentan persuadir al lector sobre la necesidad de un plan hídrico. 


\section{10. Los riesgos a la salud.}

“Antes poco fumigaban, no pasaban con el avión, era el mosquito nomás.

Pero habia más respeto, se fumigaba nomás si no había viento; ahora no les interesa nada si hay viento o no hay viento. Y si pasan, si han fumigado en la mañana hay que estar todo el día encerrado porque si no le hace mal a los chicos". Simona, integrante del Movimiento Campesino de Santiago del Estero (2012:99).

UA 57. La noticia que nos ocupa se encuentra en el diario Página 12, en su edición del 18 de febrero de 2013. Se ubica en el rubro Sociedad y ocupa un $40 \%$ de la página 18 . La cantidad de espacio que utiliza, su posicionamiento sobre la línea de "indicatividad", el uso de fotografía y de todos los elementos de titulación, señalan una manera de jerarquizar el acontecimiento.

El título "Polémica por los transgénicos" enuncia una situación y asocia a los transgénicos con la idea de controversia o discusión. En cuanto a la lexicalización, Página 12 utiliza el término "transgénico" con el que se denomina comúnmente a los Organismos Genéticamente Modificados (OGM u OMG). Mientras que en el diario La Nación se emplean los dos términos como sinónimos. Desde el ámbito científico, la consultora de la Organización de las Naciones Unidas para la Agricultura y la Alimentación (FAO), Sandra Sharry, señala que la denominación correcta es OGM y no los "mal llamados alimentos transgénicos"43.

Recién en la volanta se anuncia un hecho: “Cuestionan en la Universidad de Córdoba la instalación de una planta de semillas". Como puede observarse, se asocia nuevamente la idea de controversia, pero ahora a un hecho concreto: la instalación de la planta de semillas. Y, además, el verbo encabeza la oración para expresar con mayor énfasis la acción. En estos elementos de lectura rápida se señala de manera explícita que desde el ámbito académico se pone en duda la instalación de un establecimiento para almacenar semillas transgénicas.

La bajada, por su parte, otorga datos contextuales y menciona a la multinacional que trabaja en la instalación de la planta: "Un informe elaborado en la Facultad de Ciencias Médicas advierte sobre los problemas de salud en la localidad de Malvinas Argentinas y reclama evitar la planta de transgénicos de Monsanto. La empresa dice que su accionar 'está dentro de las leyes vigentes'”.

\footnotetext{
${ }^{43}$ En El Diario, publicación de La Paz Bolivia, 18 de mayo de 2005, "Experta de la FAO: Transgénicos no amenazan integridad medioambiental".
} 
En este elemento de titulación aparece una relación de oposición entre la compañía multinacional que quiere instalar la planta y la Facultad, que está en contra de su funcionamiento en el lugar.

Se trata de un discurso que da una versión de alta referencialidad, ya que acerca lo más posible a un tema con versiones a favor y en contra de la instalación de la planta de acopio de Monsanto, que prevé la construcción de 240 silos con capacidad para almacenar 16 toneladas cada uno. A lo largo del texto aparecen relaciones de oposición que se pueden apreciar en la inclusión de la palabra ajena. Dichos enunciados se introducen a través de citas mixtas y en función de las personas que hablan; es decir, como voces autorizadas.

Por un lado, se toma como fuente principal la investigación "Análisis de la salud colectiva ambiental de Malvinas Argentinas", elaborada por profesionales pertenecientes a cuatro cátedras de la Facultad de Ciencias Médicas de la Universidad Nacional de Córdoba: Luciana Ruderman (Red Universitaria de Ambiente y Salud), Betiana Cabrera Fasolis (Cátedra de Medicina Psicosocial), Gloria Dozzo (Alergia e Inmunología), Carlos Nota (Medicina I) y Medardo Ávila Vázquez (Clínica Pediátrica). Dicho trabajo entrecruzó información social y económica y obtuvo datos sanitarios de 3563 personas de la localidad cordobesa de Malvinas Argentinas. A raíz de este estudio pudo conocerse que los pobladores del lugar padecen enfermedades respiratorias y de la piel, además de abortos espontáneos y nacimientos con malformaciones, al habitar una zona próxima a campos fumigados:

- 'La investigación 'Análisis de la salud colectiva ambiental de Malvinas Argentinas' destaca la existencia de casos de bronquiolitis, bronquitis, asma y alergias, que 'comprometen a la mayoría de los niños del pueblo'. 'Se trata de una población que padece enfermedades respiratorias de manera llamativamente más frecuente e intensa que en otras poblaciones', señala”.

- "Detalla (por la investigación) que la localidad tiene una prevalencia de 15,46 por ciento en neumopatías (enfermedades pulmonares) y la zona más expuestas a fumigaciones (el barrio Nicolás de Bari) llega al 20,25 por ciento, lo relaciona con la `elevada contaminación' del aire con polvo proveniente de los campos vecinos".

- "Los investigadores relevaron a 178 mujeres que padecieron abortos espontáneos en los últimos años. 'Una prevalencia de 22 por ciento de mujeres en edad reproductiva (MER) 
en la muestra estudiada. En el Nicolás de Bari tiene el valor más elevado (25,6 por ciento) '. El Centro de Estudios de Estado y Sociedad y el Centro de Estudios de Población estiman que en Argentina los abortos espontáneos tienen una prevalencia de 0,6 por ciento de MER. 'Un valor de 22 por ciento de abortos espontáneos en Malvinas Argentinas nos dice que algo grave está pasando', advierte la investigación. También detectaron 42 casos de nacimientos con 'defectos'”.

El discurso reproduce además, dos fragmentos de la investigación en donde se expide en contra de la instalación de la planta de acopio de granos, al considerar que sus efectos contaminantes pueden ocasionar daños en la salud de la población:

- "La experiencia de los pueblos agrícolas nos enseña que vivir alrededor de los granos es de alto riesgo para patologías respiratorias', advierte la investigación”.

- "Los investigadores, luego del estudio interdisciplinario, concluyeron: `Someter a esta población a un nuevo golpe en su salud ambiental, como el que generará una enorme planta de semillas transgénicas de Monsanto, no es recomendable desde el punto de vista médico, y es intolerable desde el punto de vista social'".

- “(...) recomendaron 'no someter a la población a los efectos de, entre otros contaminantes, el polvo de cereales que emanará de los silos y la actividad productiva de Monsanto'",

Y, por otra parte, se otorga la palabra- a través de citas mixtas- a la jefa de Prensa de Monsanto, Fernanda Pérez Cometto, quien defiende los protocolos de seguridad de la empresa y, por lo tanto, brinda información positiva sobre ésta:

- “(...) señaló que no tuvieron acceso a la investigación, pero remarcó que tienen una planta similar (aunque de menor envergadura) en Rojas (Buenos Aires) y 'nunca se detectaron problemas en la población, todas nuestras plantas cumplen los más altos estándares de seguridad'. Respecto del rechazo que genera la instalación de Monsanto, Pérez Cometto apuntó a la 'desinformación' de quienes se oponen y explicó que apuntan al 'diálogo de todos los sectores'. Ante la posibilidad de una consulta popular (como propone la Asamblea de Vecinos Malvinas Lucha por la Vida), desde Monsanto destacaron que `lo deben decidir las autoridades municipales'”. 
En la noticia también se relaciona las enfermedades de la población con las fumigaciones de agroquímicos; a los que Página 12 denomina "pesticidas" y "agrotóxicos". Como puede observarse, este último término posee connotaciones negativas teniendo en cuenta que califica de tóxicos a los productos fitosanitarios.

- 'Nicolás de Bari tiene 1,83 casos (de nacimientos con defectos) por cada cien vecinos encuestados, mientras que la zona menos expuesta a agrotóxicos tiene 0,66 por ciento. 'Se verificó que hay mayor probabilidad de tener hijos con malformaciones si el hogar está más cerca de campos fumigados con agrotóxicos', explica”.

- "El alto impacto encontrado en salud reproductiva, respiratoria y dérmica más la distribución espacial de las mismas, incluyendo tumores y cánceres, con mayor presencia en las zonas más expuestas a los pesticidas, reflejan grados de vulnerabilidad ambiental muy grandes".

Finalmente, el discurso reproduce un fragmento del informe en donde se brinda un juicio de valor negativo sobre el municipio, al señalar su incapacidad para atender los problemas sanitarios:

- “La vulnerabilidad de la población es de las más altas de Córdoba y la capacidad del Estado municipal de responder a la demanda de enfermedad es mínima', afirma”.

La noticia se encuentra acompañada de una subnota titulada, "La planta más grande"; también redactada por el periodista Darío Aranda. La misma, brinda datos contextuales sobre la localidad de Malvinas Argentinas y la planta que Monsanto pretende instalar.

El discurso predica que Malvinas Argentinas se ubica en el Gran Córdoba, "cercada por soja” y que sus pobladores conformaron la Asamblea de Vecinos luego de enterarse por televisión, en junio de 2012, que tendrían como vecina "a la empresa de agronegocios más grande del mundo". Señala además, que "desde la Asamblea se organizaron cortes informativos y movilizaciones (en septiembre hubo una multitudinaria marcha en la capital provincial). También se recurrió a la vía judicial y presentaron un proyecto en la Legislatura para evitar la instalación. Pero la municipalidad aprobó en enero la construcción de la planta”.

En cuanto a las citas, se otorga la palabra a un referente de la Asamblea vecinal, que se manifiesta en contra de la instalación de la planta de acopio, en su calidad de voz autorizada:

- “La investigación socio-sanitaria aporta datos que preocupan y tienen relación directa con lo que denunciamos de las fumigaciones. Vivimos una situación delicada y con la 
instalación de Monsanto colapsará el barrio', afirmó Matías Marizza, de la Asamblea, y pidió que `los gobernantes escuchen lo que dicen los investigadores y lo que quiere la población de Malvinas'".

El discurso señala de manera implícita que las fumigaciones en los campos de soja y los agronegocios son los responsables de las condiciones sanitarias de la población del lugar.

Puede observarse además, la existencia de un conflicto de intereses entre los gobernantes, que apoyan la instalación de la planta y dos Universidades Nacionales y la Asamblea de vecinos, que están en contra:

- "La llegada de Monsanto a Córdoba fue anunciada en junio pasado por la Presidenta y respaldada por el gobernador, José Manuel de la Sota, y el intendente radical, Daniel Arzani".

- "Dos universidades nacionales (de Córdoba y de Río Cuarto) cuestionaron la instalación de Monsanto. Recordaron las denuncias de contaminación que pesan sobre la compañía, alertaron sobre las consecuencias sociales y ambientales del modelo agropecuario, llamaron a respetar el principio precautorio de la Ley General del Ambiente y exhortaron a respetar la decisión de las poblaciones afectadas".

UA 58. La noticia seleccionada se ubica en la edición del lunes 20 de mayo de 2013 de Página 12. Ocupa alrededor del $80 \%$ de la página 14 correspondiente al rubro Sociedad. Como pudimos observar en las UA 48, 49, 50 y 51, este diario sitúa los temas referidos a la expansión de la frontera agropecuaria en dicha sección.

La cantidad de espacio utilizado, el titular desplegado en cuatro de las cinco columnas de la página, el empleo de una fotografía y de un cuadro con información que contextualiza el acontecimiento, son elementos que indican que se trata de la noticia principal de la página y de una de las más importantes en la sección.

El título, "La salud cercada de Avia Terai", es editorial. A través del adjetivo subjetivo "cercada" el enunciador aplica un juicio de valor negativo para señalar que la salud de un pueblo se encuentra acorralada por las fumigaciones en los campos vecinos. 
La volanta indica de manera explícita que los casos de cáncer están relacionados con el uso de agroquímicos y de semillas transgénicas: "Fumigaciones y campos transgénicos elevan los casos de cáncer”.

La bajada por su parte, alude a la principal fuente consultada, que relaciona a las fumigaciones en campos de soja con el cáncer: "Un estudio interdisciplinario auspiciado por el Ministerio de Salud de la Nación determinó que en Avia Terai, una localidad chaqueña rodeada de campos de soja y continuamente fumigados, más del 31 por ciento de la población tiene un pariente con cáncer”.

Como se adelantó, el discurso toma como fuente principal el estudio denominado "Relación entre el uso de agroquímicos y el estado sanitario”, que encuestó a 2051 personas de las localidades chaqueñas de Avia Terai, Campo Largo, Napenay y La Leonesa. El trabajo utiliza datos oficiales del ámbito de la salud y fue elaborado por seis médicos, licenciados en enfermería y geógrafos. Las citas son incluidas en función de las personas que hablan, en su calidad de voces autorizadas al formar parte de un equipo de investigación encabezado por Mirta Liliana Ramírez, doctora en cartografía, directora del Laboratorio de Tecnologías de la Información Geográfica (UNNE), investigadora independiente del Conicet y autora del libro Geografía de la Salud del Chaco; y compuesto además por, Braulio Santiago Belingheri, María Beatriz Nícoli, María del Carmen Seveso, Lina Alba Ramírez y Mercedes Beatriz Garcete.

Teniendo en cuenta las proposiciones planteadas por van Dijk, en este discurso los pobladores de las localidades cercanas a plantaciones de soja, girasol y arroz donde se fumiga, aparecen como víctimas o afectados por un modelo agropecuario que ocasiona consecuencias en la salud:

- "Las cuatro localidades que se han caracterizado como asentamientos en los que se desarrolla el modelo agroproductivo, empleando los paquetes tecnológicos que incluyen semillas transgénicas y empleo de agroquímicos, tienen respuestas por encima del $20 \mathrm{y}$ hasta el 38 por ciento, mientras que las dos localidades caracterizadas como ganaderas arrojan valores muy bajos', alerta la investigación”.

- "El trabajo detalla bibliografía científica que advierte de malformaciones y cáncer en zonas con uso intensivo de agrotóxicos, recuerda que la aparición de malezas resistentes llevó a que ‘con el fin de sostener la productividad se aplican cantidades cada vez 
mayores de agroquímicos', y recuerda que los más afectados son niños y mujeres embarazadas".

En cuanto al cuadrado ideológico de van Dijk, el discurso expresa información negativa sobre las fumigaciones y los daños que ocasionan en la salud de las personas que habitan cerca de los campos con cultivos de soja, girasol y arroz. Al respecto, predica que:

- "En Avia Terai se entrevistó a 390 personas. El 31,3 por ciento de la población declaró haber tenido un familiar con cáncer en los últimos 10 años".

- En la misma localidad existen "101 niños y jóvenes con discapacidad”.

- "En la localidad de Campo Largo, el 10 por ciento de las mujeres y el 15 por ciento de los hombres manifestaron tener algún tipo de discapacidad. El 29,8 por ciento reconoció tener familiares con cáncer en los últimos diez años. En Napenay, el 20 por ciento de los hombres manifestó tener algún tipo de discapacidad, y el 38,9 por ciento señaló la existencia de algún familiar con cáncer. En La Leonesa, zona arrocera, el 27,4 por ciento de la población declaró tener familiares con cáncer”.

Se otorga también la palabra a Alejandra Gómez, de la Red de Salud Popular Ramón Carrillo, quien brinda un juicio de valor negativo sobre el actual modelo agropecuario: "Se sigue priorizando la 'productividad' y el rendimiento de los agronegocios sin tener en cuenta los costos sociales y ambientales, ni la salud y la vida. No se cumplen las leyes y el Estado sigue ausente en materia ambiental. Debe quedar claro que junto al avance de la frontera agrícola avanza el desmonte y las enfermedades en la población".

En este discurso, la soja, las fumigaciones y el modelo agropecuario están asociados a los siguientes léxicos: cáncer, discapacidad, enfermedades, tumores, malformaciones congénitas, desmonte, avance de la frontera agrícola, reducción de la fertilidad masculina, enfermedades neurológicas, reducción del crecimiento, anormalidades fetales, fatiga crónica en niños y mal de Parkinson.

Por otra parte, los agroquímicos aparecen categorizados de manera negativa como "agrotóxicos"; término informal utilizado para señalar que dichos productos son nocivos para los seres humanos.

El discurso presenta una alta referencialidad sobre la ubicación geográfica de Avia Terai y brinda una adecuada cantidad de información sobre los cultivos de la zona y las actividades que 
giran en torno al modelo agropecuario. Todo esto para comprender el contexto en el que se originan los daños a la salud:

- "Avia Terai es una localidad de cinco mil habitantes en el centro geográfico de Chaco. El casco urbano está, literalmente, rodeado de cultivos de soja y girasol que son fumigados entre diez y doce veces al año".

- "En el ingreso a Avia Terai se ubica una semillera transgénica (Mandiyú) y una agroquímica (Ciagro), con campos experimentales. En la entrada al pueblo sobresale una pista de aviones fumigadores. También está presente la multinacional cerealera Bunge, con carga-descarga de camiones".

En cuanto a las marcas de subjetividad del enunciador, en el discurso aparece un adjetivo que según la clasificación de Orecchioni pertenece a los evaluativos no axiológicos: "Los muy altos índices de cáncer, y también de discapacidad, se repitieron en otras tres ciudades cercadas por campos transgénicos: Campo Largo, Napenay y La Leonesa”. Si bien este tipo de adjetivos no enuncia un juicio de valor, implica una evaluación cuantitativa o cualitativa del objeto denotado. En el discurso se señala que, según la investigación el modelo agropecuario y el contacto de la población con agroquímicos originan daños a la salud:

- "La investigación vincula la causa de las enfermedades con el modelo agropecuario".

- "Y explicaron que priorizaron los casos de tumores y las malformaciones congénitas porque `se asocian a la exposición con agroquímicos'”.

En el último párrafo de la noticia se reproducen recomendaciones de los investigadores, en las que solicitan que la Justicia actúe con celeridad para frenar las fumigaciones en cultivos cercanos a zonas habitadas: "En el capítulo final, los investigadores (...) recuerdan el fallo judicial que frenó fumigaciones en la localidad de La Leonesa, pero advierten que en muchas otras ciudades 'la población aún sigue esperando y por ello creemos que se debe actuar de forma más rápida frente a situaciones en las que se vulnera la salud"'.

Como señalamos anteriormente, la noticia es acompañada por un recuadro titulado, "A la espera de la devolución”. Allí se explica que la investigación fue realizada en el marco de la Beca Ramón Carrillo-Arturo Oñativia del Ministerio de Salud de la Nación, a través de la Comisión Salud Investiga. Y, advierte que, los resultados fueron presentados en mayo de 2012 a los ministerios de Salud de la Nación y de Chaco, pero "aún no hubo una devolución al equipo 
investigador". Seguidamente, introduce una cita directa de la médica María del Carmen Seveso, integrante del equipo de investigación, quien descalifica el accionar de los Ministerios de Salud Provincial y Nacional, y los acusa de ocultar lo que sucede en los pueblos cercanos a campos fumigados: "No es ético ocultar lo que pasa. Se está hipotecando el futuro, hay niños con malformaciones y lesiones neuronales, se está envenenando a seres humanos. Hay que frenar esto".

La imagen que acompaña al texto retrata a una avioneta fumigando un campo sembrado con soja. Según la clasificación de Thibault Laulan, se trata de una fotografía que intenta documentar el hecho.

UA 59. La noticia titulada "Agrotóxicos pampeanos" se encuentra en la edición del 18 de noviembre de 2013 del diario Página 12. Ocupa alrededor del 80\% de la página 18 en el rubro Sociedad. El espacio asignado y su ubicación sobre la línea de indicatividad, señalan una manera de jerarquizar el acontecimiento.

El diario titula de manera editorial, representando de manera negativa a los productos fitosanitarios, a los que califica de tóxicos. La volanta, más informativa, indica la existencia de "Denuncias en tres provincias por las fumigaciones". Mientras que la bajada alude a la existencia de un conflicto entre pobladores y productores que fumigan; además de mencionar cuales son las provincias que "dan batalla" a los "agrotóxicos": "Con el avance de las fumigaciones, cada vez más pueblos dan batalla a los agrotóxicos. A los casos de Córdoba y Santa Fe, ahora también se suma la provincia de Buenos Aires".

La nota, redactada por el periodista Darío Aranda, describe la situación de las localidades de Alberti, Buenos Aires; San Jorge, Santa Fe y Río Cuarto, Córdoba; pertenecientes a la región conocida como Pampa Húmeda; en donde existen casos de personas que fueron fumigadas con agroquímicos y en las que se "cuestiona al modelo agropecuario". A lo largo del discurso se citan casos en los que se incumplen fallos judiciales y se continúan fumigando viviendas.

Teniendo en cuenta las estrategias de fondo del discurso planteadas por Prieto Castillo, se trata de una versión de alta referencialidad que acerca lo más posible al tema, mediante detalles precisos y descripciones acerca de los pueblos fumigados. Señala, por ejemplo, la experiencia de María Cristina Monsalvo y Víctor Fernández, habitantes de Alberti que "comenzaron a ser 
fumigados en 2006" con glifosato, atrazina y cirpermetrina por un vecino que sembraba soja. El caso llegó a tribunales y “en agosto de 2012, la Corte Suprema de Buenos Aires prohibió fumigar a menos de 1000 metros de las viviendas. Incluso citó el principio precautorio vigente en la ley: ante la posibilidad de perjuicio ambiental irremediable, es necesario tomar medidas protectoras". Predica además, que pese al fallo "la Municipalidad autorizó fumigaciones a cien metros de las casas. En enero pasado rociaron con glifosato a sólo 40 metros de la vivienda de MonsalvoFernández y a cincuenta metros del polideportivo municipal, el mismo día en que comenzaba la colonia de vacaciones de cientos de niños. La primera semana de noviembre volvieron a fumigar a metros del polideportivo y a 300 metros de la casa familiar que la Corte Suprema había protegido". Como puede observarse, el discurso alude al incumplimiento de medidas judiciales por parte de los productores y de la misma Municipalidad de Alberti.

Se predica además que, las fumigaciones sobre viviendas particulares y escuelas se repiten en las localidades de Carmen de Areco, Cañuelas, Chacabuco, Rojas, Luján, Ramallo, Marcos Paz, Los Toldos, Saladillo y en Guernica, partido de Presidente Perón, a 40 kilómetros de Capital Federal. Hechos que no aparecen mencionados en el diario La Nación, donde las denuncias por exposición a agroquímicos son omitidas.

Cabe señalar, que en este discurso Página 12 da cuenta de sectores organizados que luchan contra las fumigaciones, como la "Multisectorial Paren de Fumigarnos" y la "Asamblea por un Río Cuarto sin Agrotóxicos”. Los pobladores aparecen en su doble rol de afectados y dirigentes. Por un lado, son víctimas de "intoxicaciones, alergias y problemas respiratorios" y por otra parte, debaten sobre las distancias de fumigación permitidas en las legislaciones provinciales, denuncian el incumplimiento de fallos judiciales y proponen sistemas de producción sustentables:

- "Otras localidades de Santa Fe donde existen asambleas y rechazos al modelo son Alvear, Carcarañá, San Lorenzo, Desvío Arijón y San Justo, entre otros. A nivel provincial, la Multisectorial Paren de Fumigarnos (que nuclea a decenas de localidades y organizaciones) impulsa una ley que prohíba por completo las fumigaciones aéreas y legisle un resguardo de 800 metros libre de agroquímicos".

- "Río Cuarto está ubicada al sur de Córdoba. En junio pasado, cuando la empresa Monsanto anunció la instalación de una planta de experimentación en la ciudad (otra en Tucumán y una gran planta de semillas en la localidad cordobesa de Malvinas 
Argentinas), nació la Asamblea por un Río Cuarto sin Agrotóxicos. Comenzaron una 'iniciativa popular' para que se aprobara una ordenanza que establezca un territorio libre de agroquímicos, y proponen una transición del modelo de transgénicos y químicos hacia la agroecología”.

- "Similares debates y críticas se repiten en las localidades cordobesas de Morrison, Huinca Renancó, General Levalle, Coronel Moldes, General Cabrera, Las Perdices, Coronel Baigorria, Villa Ciudad Parque e Italó, entre otros. En Alta Gracia está vigente una ordenanza que prohíbe fumigar a 1500 metros de la zona urbana, pero productores quieren vetar la ordenanza".

En cuanto a la polifonía de voces en el enunciado, Página 12 otorga la palabra - a través de citas directas- a personas relacionadas con los hechos y testigos que brindan descripciones negativas sobre las fumigaciones. Las declaraciones se producen en función de las personas que hablan, por lo tanto aparecen como voces autorizadas:

- "El fallo de la Corte establece que para otorgar permisos deben hacer primero estudios ambientales, audiencia pública y recién luego dar permiso. Nada de eso se cumple', denunció Cristina Monsalvo (vecina de la localidad de Alberti) y alertó: ‘Seguiremos en la lucha contra este modelo que no duda en sacrificar a las poblaciones'”.

- "El 10 de septiembre se realizó un debate público en el Concejo Deliberante (de Río Cuarto), con 70 expositores que disertaron tanto en apoyo como con críticas al modelo agroindustrial. 'Si no son peligrosos los agrotóxicos, ¿por qué fumigan de noche? ', preguntaron dos nenas de 9 años de la escuela primaria Eva Duprat, ubicada frente a un campo fumigado".

- "Viviana Peralta, una de las madres que iniciaron la denuncia (San Jorge, Santa Fe), afirmó que las fumigaciones volvieron a fines de 2012. 'Y volvimos a denunciarlos. Ahí frenaron. Tienen que entender que la Justicia ya dijo que paren y que la salud es lo primero', reclamó".

Por otra parte, en el discurso, el modelo agropecuario y las fumigaciones están asociados a léxicos negativos que dan cuenta de los daños que ocasionan a la salud de la población: “agrotóxicos”, "peligrosos", “intoxicaciones”, “alergias”, “problemas respiratorios”, enfermedad, "nocivos" y "contaminación". 
La noticia está acompañada por una nota anexa titulada, "Polémica por las distancias", en donde aparece lo que Prieto Castillo denomina "Relaciones de oposición", entre médicos y organizaciones sociales que solicitan límites de entre 800 y 1500 metros para las fumigaciones y el Ministerio de Agricultura de la Nación que "distribuyó entre productores un documento que propone fumigar a cien metros de las viviendas".

Seguidamente, se otorga la palabra a referentes de distintas organizaciones ambientalistas para polemizar y descalificar el documento del Organismo estatal, lo que podría indicar que el enunciador se vale de voces autorizadas para expresar su evaluación sobre el hecho:

- “El documento llamado Pautas sobre aplicaciones fitosanitarias en áreas periurbanas, carece de nivel científico, ignora por completo el conocimiento disponible sobre efectos nocivos de los plaguicidas en la salud y los ecosistemas, y facilita la contaminación de las personas', afirmó desde la Fundación para la Defensa del Ambiente (Funam) Raúl Montenegro, y destacó que 'no es casual' que funcionarios y grandes productores omitan mencionar que en la Comunidad Europea está prohibida la fumigación aérea”.

- "Horacio Brignone, de la Multisectorial Paren de Fumigarnos de Santa Fe, calificó el documento de 'burdo, es el trabajo de una voluntad sectorial corporativa'...”.

- “Claudio Lowy, desde la Red Nacional de Acción Ecologista (Renace), consideró que el documento `carece de legitimidad científica, política y jurídica"”.

- “Carlos Manessi, de Cepronat (Centro de Protección a la Naturaleza) y la Multisectorial, explicó que están trabajando en todo Santa Fe, señaló que se articulan acciones con otras provincias y con todos los sectores de la sociedad por un simple motivo: 'El lobby sojero opera en la Legislatura, en los medios de comunicación, en las universidades. En todos lados encuentra socios, pero también resistencias'”.

La noticia y la nota anexa están acompañadas además, por una fotografía que retrata a una avioneta fumigando un campo con plantaciones de soja. Se trata de una imagen documental que demuestra la existencia de fumigaciones aéreas. Su epígrafe explica, "Decenas de pueblos de la Pampa Húmeda cuestionan la fumigación a sólo 100 metros de las casas”.

UA 60. La noticia titulada "La contaminación en las aulas" se ubica en el diario Página 12, en su edición del 15 de abril de 2014. Ocupa alrededor del 80\% de la página 20 perteneciente al rubro 
Sociedad. El espacio asignado, coincidente con la línea de indicatividad, el título desplegado en cuatro de las cinco columnas de la página y una fotografía que ocupa alrededor del $20 \%$ de la página, son maneras de jerarquizar el hecho.

El título enuncia una situación, más que anunciar un hecho y requiere de los demás elementos de la titulación para su comprensión. Como señala Verón, este tipo de titulares se utiliza con mayor frecuencia en semanarios.

La volanta señala: "Campaña de gremios y organizaciones contra fumigaciones que afectan a escuelas". Mientras que la bajada resalta: "Ocurre en muchas escuelas rurales, ubicadas cerca de campos donde hay plantaciones de soja. En algunas provincias hay legislación que pone límites, pero muchas veces no se cumplen. Reclaman mayores controles".

Como puede observarse en los elementos de titulación, las fumigaciones en plantaciones de soja están asociadas al léxico negativo "contaminación” y se alude al incumplimiento de la normativa referida a la aplicación de agroquímicos.

La noticia trata sobre la campaña "Paren de fumigar escuelas" organizada por asambleas socioambientales, gremios docentes y padres de alumnos. La misma da cuenta de "miles de escuelas rurales rodeadas por cultivos transgénicos, donde llueven agroquímicos sobre niños y maestros”, señala el periodista que firma la nota, Darío Aranda. Cabe señalar que dicha campaña no aparece mencionada en el diario La Nación y por ende, tampoco se dan a conocer los casos de escuelas fumigadas ni los daños a la salud de los alumnos expuestos a los agroquímicos.

A lo largo de la noticia se describen los casos de escuelas rurales fumigadas en las provincias de Córdoba, Buenos Aires, Entre Ríos y Chaco; todos ellos denunciados en la mencionada campaña. Y, se menciona además, que en Santiago del Estero, Salta, Santa Fe, La Pampa y Formosa también ocurrieron situaciones similares en establecimientos educativos afectados por la aplicación de agroquímicos:

- "El único informe oficial del país sobre escuelas y agroquímicos se realizó en Coronel Suárez, provincia de Buenos Aires: 41 establecimientos educativos fueron fumigados”.

- "Un caso testigo sucedió en octubre de 2012, cuando fue fumigada la escuela rural No 66 de Gualeguaychú. Los chicos padecieron picazón en los ojos, dolores de garganta y vómitos". 
- "El sindicato docente de Entre Ríos (Asociación Gremial del Magisterio, Agmer) y la Asamblea Ciudadana Ambiental de Concepción del Uruguay comenzaron un relevamiento en toda la provincia. Ya avanzaron en tres departamentos (Uruguay, Nogoyá y Gualeguaychú). Sobre 74 escuelas censadas, el 70 por ciento fue fumigado (52). En el departamento de Uruguay sufrieron aspersiones 15 escuelas de las 28 censadas. En Nogoyá, 18 sobre 23. Y en Gualeguaychú fueron fumigadas 19 escuelas sobre 23 relevadas. Confirmaron casos de afecciones en la piel y vías respiratorias de chicos y maestros, vómitos y problemas gastrointestinales".

- "En Buenos Aires hubo denuncias de escuelas fumigadas en Exaltación de la Cruz, Cañuelas y Los Toldos".

- "Estimaciones de Médicos Fumigados y sindicatos docentes provinciales señalan que en Córdoba hay 1500 escuelas a menos de 1000 metros de campos fumigados. 'De esas 1500, hay 400 escuelas rodeadas de campos de soja y maíz transgénico. Unos 12 mil alumnos y 900 maestros están expuestos a los agrotóxicos', afirmó Avila Vázquez, que también forma parte de la "Campaña escuelas fumigadas nunca más. Los casos se repiten en todas las provincias con cultivos transgénicos: Santiago del Estero, Salta, Santa Fe, La Pampa y Formosa, entre otras".

- "La escuela $\mathrm{N}^{\circ} 552$ de Pampa del Indio, donde se fumigaba con los chicos en clases; la escuela N ${ }^{\circ} 141$ Fortaleza Campesina, en el departamento General San Martín, donde se usó glifosato a menos de 100 metros de los alumnos; y la escuela $\mathrm{N}^{\circ} 257$ de Tres Isletas, son sólo algunos de los casos".

En el discurso, se introduce la palabra "ajena" de activistas de la Asamblea Ciudadana Ambiental de Concepción del Uruguay, de la Red de Médicos de Pueblos Fumigados y del Foro Ambiental de Los Toldos, para despertar polémica sobre el uso de agroquímicos en campos cercanos a escuelas rurales de diferentes provincias argentinas. Como puede observarse las voces provienen de sectores ecologistas que denuncian el incumplimiento de la normativa vigente, se manifiestan en contra de la inacción de los gobiernos local y nacional y advierten que los docentes temen denunciar las fumigaciones:

- "En Cañuelas, en 2010, se sancionó una ordenanza (la 2671) que regula la aplicación de agroquímicos, tomada como referencia por otras localidades. Limita las fumigaciones a 
2000 metros de poblaciones urbanas y 200 metros de distancia de escuelas rurales. Diana Iceruk, periodista y asambleísta socioambiental, asegura que la ordenanza 'no se cumple plenamente, se continúa fumigando en zonas prohibidas'",

- "Medardo Ávila Vázquez forma parte de la Red de Médicos de Pueblos Fumigados. Detalló que en Córdoba los mayores problemas se dan en septiembre con las aplicaciones de glifosato, 2.4D y atrazina. 'Son de tres a seis aplicaciones antes de la siembra de noviembre-diciembre, los chicos aún están en las escuelas y los fumigan sin reparos', denunció".

- "En Buenos Aires hubo denuncias de escuelas fumigadas en Exaltación de la Cruz, Cañuelas y Los Toldos. 'Hay muchos casos, pero los docentes tienen miedo. Algunos directivos y funcionarios son amigos de empresarios sojeros. Además está Cargill, que hace donaciones a las escuelas y eso complica todo', explicó Margot Goycochea, del Foro Ambiental de Los Toldos".

El hecho de reproducir la opinión de referentes ambientalistas y omitir el descargo de sectores gubernamentales puede explicarse en palabras de Ulanovsky: "Página 12 ofreció de entrada costados distintos, como información sobre grupos minoritarios e influyentes en la sociedad gays, lesbianas, feministas, ecologistas, psicoanalistas y militantes de los derechos humanos- con buen criterio recuperó la importancia de dos secciones poco a poco relegadas en otros medios, 'Educación' y 'Universitarias' (...)” (1997: 333).

Ahora bien, Página 12, hace públicos los casos de escuelas fumigadas pero citando la fuente que los denuncia; es así que, el enunciador toma distancia del discurso citado, situación que puede observarse en las fórmulas introductorias del discurso referido: "reclaman mayores controles", "denunció", "cuestiona", "realiza recomendaciones", "recomienda" y "solicitó medidas urgentes".

A continuación, se detallan los léxicos y las predicaciones que aparecen en el discurso:

Campo semántico de lexemas que refieren a las acciones que se producen:

- "llueven agroquímicos sobre niños y maestros".

- "se continúa fumigando sobre zonas prohibidas".

- "se fumigaba con los chicos en clases". 
- "se usó glifosato a menos de 100 metros de los alumnos".

- “aplicación de agrotóxicos”.

Campo semántico de lexemas que refieren a las escuelas:

- "rodeadas por cultivos transgénicos".

- “expuestas a la deriva".

- “desprovistas de las mínimas garantías para la salud".

Campo semántico de lexemas que refieren a alumnos y maestros:

- “expuestos a los agrotóxicos".

- “tienen miedo a denunciar".

- "casos de afecciones en la piel y vías respiratorias de chicos y maestros, vómitos y problemas gastrointestinales".

Por su parte, la fotografía que acompaña a la noticia documenta una avioneta volando sobre una señal de tránsito que indica la existencia de una Escuela. Mientras que la bajada expresa: "Atención escuela. Señor aplicador y productor. No fumigar', dice un cartel en una escuela de Entre Ríos”. 


\section{CONCLUSIONES}

El estudio ha demostrado que en los diarios argentinos La Nación y Página 12 existe un caudaloso flujo de información sobre el modelo productivo sojero en el periodo de agosto de 2012 a julio de 2014, pero el tratamiento informativo de las noticias construidas por cada diario fue disímil. En este sentido, puede señalarse que cada periódico diagramó y valoró los acontecimientos conforme principios editoriales que les permitieron organizar "la multitud de creencias sociales acerca de lo que sucede" (van Dijk, 2000).

A lo largo de la investigación se demostró que las unidades de análisis (UA) que integraron el corpus no presentan en sus discursos una superficie lisa y neutra, sino más bien colmada de huellas que remiten al sujeto de la enunciación.

En primer lugar, estos diarios se diferencian por la manera en que estructuran el espacio discursivo propio; dentro de cada página y en la organización del conjunto; es decir, en la diagramación. Por empezar, Página 12 posee un formato tabloide, mientras que La Nación uno sábana; además el primer diario posee 32 o 40 páginas (conforme la edición), más segmentos especiales y el cuerpo principal del segundo 38, más los suplementos que lo acompañan según el día de la semana.

Hemos observado que los criterios de selección y jerarquización que posee cada diario operan en función de los intereses de cada medio y conforme al público al que cada uno quiere llegar. Las noticias sobre la soja ocupan diferentes rubros de los diarios, de acuerdo al enfoque que posee el discurso. En La Nación se ubicaron generalmente en el rubro Economía- el segundo en importancia después de Política- para informar sobre la cotización de la oleaginosa en diferentes mercados, brindar estimaciones sobre la cosecha y evaluar las políticas implementadas por el Gobierno Nacional. En estos casos la soja está asociada a la idea de una mercancía que puede venderse o comprarse y que posee distintos valores conforme los mercados nacionales e internacionales.

Las noticias sobre soja también fueron una constante en el suplemento Campo que acompaña al diario el día sábado; en donde poseen un corte instructivo/ educativo al estar destinadas a los productores agropecuarios. Hemos visto que en este segmento especial, las noticias sobre la oleaginosa son anunciadas la mayoría de las veces en tapa y ocupan amplios espacios de las 
primeras páginas, lo que indica la jerarquización de dichos acontecimientos. Estos discursos utilizaron como fuentes a ingenieros agrónomos y productores para brindar recomendaciones sobre el paquete tecnológico y asesorar en el logro de mejores rindes.

Conforme lo analizado en las unidades ubicadas en el suplemento Campo, puede concluirse que el diario La Nación promueve el uso de paquetes tecnológicos para la producción sojera a gran escala y promociona la comercialización de las nuevas variedades de semillas genéticamente modificadas. En este sentido, pudimos observar que evaluó como positivo las investigaciones en materia biotecnológica y la aprobación del Gobierno argentino para el uso de semillas genéticamente modificadas, asociando estos hechos con el aumento de la competitividad y el desarrollo.

Tres de las UA seleccionadas se situaron también en el rubro Política. Las mismas, se enfocaron en las políticas adoptadas por el Gobierno Nacional en materia agropecuaria y en su relación con productores y empresas cerealeras.

En una oportunidad, la centenaria publicación ubicó una noticia relacionada con la soja en el rubro Seguridad cuando informó sobre el asesinato del campesino Miguel Galván en Santiago del Estero (UA49). Pudo observarse que La Nación construyó este acontecimiento como un hecho más de inseguridad en nuestro país; reduciéndolo a una cuestión delictiva y sin explicar que el crimen se produjo en un contexto caracterizado por el avance de la frontera agropecuaria y de lucha por las tierras.

Por su parte, en Página 12 las noticias sobre el modelo sojero se ubican en su mayoría en el rubro Economía; el segundo en importancia después de El País; seguido del rubro Sociedad, en donde tematizó sobre las consecuencias sociales, sanitarias y ambientales que provoca el avance sojero en nuestro país.

A diferencia del diario de los Mitre, Página 12 no posee un suplemento especial dedicado a la actividad agropecuaria. El matutino creado en la década del 80, posee otros segmentos que ayudan a configurar una idea de lo públicos a los que apunta: Radar (cultural, sale los domingos); Radar Libros (incluido en el anterior); Cash (económico); Turismo; Líbero (deportivo, se publica los lunes); NO (dirigido a los jóvenes, sale los jueves); Sátira/12 (suplemento humorístico, sale los sábados); Futuro (científico, sale los sábados); LAS12 (suplemento de género femenino); M2 (diseño, patrimonio histórico de arquitectura) y SOY. 
La UA 54, titulada "Las imágenes del desmonte" fue ubicada en el rubro Universidad debido a que informa acerca de un sistema de monitoreo para detectar la deforestación creado por la Facultad de Agronomía de la UBA. Y, finalmente, la UA 45 fue posicionada en el suplemento Cash al abordarse la soja desde una perspectiva económica.

Como pudo verse en el desarrollo de este trabajo, el diario La Nación creó los siguientes seudorrubros para ubicar noticias relacionadas con la devaluación de la moneda oficial, en enero de 2014:

- "La crisis cambiaria/ El impacto en la economía real” (UA 22).

- “La crisis cambiaria / Reservas y precios, dos frentes abiertos” (UA 24).

- "La crisis cambiaria/ Estrategia de la Casa Rosada" (UA 25).

- "La crisis cambiaria/ Impacto en el mercado y en los salarios" (UA 26).

Cabe destacar que en este sistema de organización, el matutino nacional categoriza de manera negativa la situación económica del país, al indicar la existencia de una "crisis".

En cuanto a la diagramación de las páginas, La Nación construye textos extensos que ocupan alrededor del 40\% de cada página; casi siempre ubicados sobre la denominada "línea de indicatividad" y con titulares desplegados a modo "bandera", lo cual denota la importancia del tema. En una sola oportunidad el medio anunció una noticia sobre la soja en su portada. Como pudimos verlo en la nota titulada: "Con excepción de la soja, el Gobierno no muestra signos de una década ganada", publicada en su edición del 28 de abril de 2014 (UA 29).

Por su parte, Página 12 anunció en portada en las UA 23, 27 y 36. El 31 de enero de 2014, ocupó el $70 \%$ de su tapa con una noticia en la que su principal fuente, el ministro de Agricultura, Ganadería y Pesca de la Nación, Carlos Casamiquela, advirtió: "Los responsables son los grandes". En esta ocasión, el periódico utilizó la palabra autorizada y en cita directa del funcionario nacional para titular la noticia más importante de la edición. Pudimos ver además, que este matutino, fiel a su estilo innovador y creativo, utilizó recursos del diseño gráfico para expresar valoraciones sobre la soja. El 7 de febrero de 2014, Página 12 tituló en tapa "Se abrió la canilla"; señalando el compromiso asumido por las cerealeras para liquidar los granos que tenían retenidos en silos y silobolsas. Sobre el título se ubica un fotomontaje constituido por un grifo por el que caen granos de soja. Dicha construcción metafórica conlleva a interpretar que la 
liquidación de granos estaba obstruida pero tras una reunión entre el entonces jefe de Ministros, Jorge Capitanich, con empresarios cerealeros pudo fluir.

La soja también se construyó como "el" tema de la jornada el 21 de febrero de 2014, cuando Página 12 anunció en el $80 \%$ de su tapa un nuevo registro de la AFIP para declarar la existencia de granos almacenados. El título "Cuentas claras", basado en un refrán de uso popular, está acompañado de un fotomontaje que consiste en un contador o ábaco que en vez de cuentas redondas posee semillas de soja.

El tabloide también se caracteriza por jerarquizar la información diagramando falsas centrales, como pudimos observar en las UA 17, 23, 27, 36 y 45; todas ellas, en las primeras páginas de la publicación. Otros indicadores de jerarquía fue la utilización de títulos desplegados a modo "bandera" y la ubicación de noticias sobre el modelo productivo sojero sobre la "línea de indicatividad".

En cuanto a la titulación, el diario La Nación elaboró en su mayoría títulos informativos que anuncian un acontecimiento y en menor medida empleó títulos que enuncien situaciones, en complicidad con el lector. Los titulares de esta publicación se caracterizan por utilizar generalizaciones y describir al campo y a los ruralistas como un sector homogéneo:

- "Aumenta el malestar del campo con el Gobierno" (UA 14).

- "Rechazan los ruralistas la posible aplicación de la ley antiterrorista" (UA 15).

- "Para el campo no hay avaricia en la venta de granos, sino prudencia" (UA 19).

- "Fuerte deterioro del campo en 10 años: la soja fue la única excepción” (UA 29).

- "Atacan silos bolsas y temen que sea para que el campo venda soja” (UA 46).

Como se señaló anteriormente, en estos títulos se emplea la estrategia de superficie de la generalización, que opera sacando conclusiones a partir de algunos casos y generalizando a todos los casos semejantes. De esta manera se presenta a los productores como un sector uniforme que posee los mismos intereses, cuando la realidad demuestra que se trata de un sector diverso, estratificado y mucho más complejo de lo que el matutino nacional pretende describir. Dicha estrategia pudo ser empleada por La Nación para que los reclamos de los estratos más altos sean entendidos como los reclamos de todo el conjunto.

Según van Dijk, lo que aparece en la introducción de un discurso puede indicar relevancia; en este sentido, resulta vital analizar la información que se encuentra expresada en los titulares, 
elementos que resumen el contenido de la noticia. Pudimos observar así que los títulos de La Nación expresan información negativa sobre la Administración Federal de Ingresos Públicos:

- "La AFIP intensificó la presión a los productores de soja” (UA 30).

- "Por la cosecha de la soja, la AFIP redobló el control en campos" (UA 33).

Página 12, por su parte, se valió en su mayoría de títulos similares a los utilizados en semanarios, en los que se enuncian situaciones y se apoyan en la volanta y la bajada para ampliar los datos y contextualizar el hecho. El tabloide se caracteriza por utilizar expresiones existentes dentro del campo cultural del lector y por emplear metáforas, ironías y paradojas. En sus titulares predomina la complicidad entre el enunciador y el enunciatario, que tiene que ver con lo que Verón denomina "efecto de reconocimiento". Por ejemplo:

- "En la tercera reunión se abrió la silobolsa" (UA27), que alude al compromiso de las cerealeras de liquidar la cosecha.

- "Piedra libre para quienes se guardan la cosecha" (UA 36), empleado en una noticia en la que el diario informó acerca del nuevo registro online de la AFIP para los tenedores de granos.

- "Reclamos del otro campo" (UA 52), en donde reconoce la existencia de otros sectores de la ruralidad que no están representados por la Mesa de Enlace.

La palabra ajena, fue utilizada en titulares de los periódicos seleccionados pero con orientaciones divergentes. En la UA 24, La Nación empleó declaraciones del ex jefe de Ministros para despertar la polémica: "Capitanich acusó a productores de 'amarrocar' la cosecha y dijo que se busca desestabilizar”. El mismo diario tituló en la UA 28, “El próximo gobierno debe mejorar la relación con el campo', dijo Grobocopatel"; utilizando una cita directa que expresa el deseo de un conocido empresario en defensa de los intereses de un sector particular de la ruralidad. Mientras que en la UA 23, Página 12 resaltó las palabras del Ministro de Agricultura, Carlos Casamiquela: "Los responsables son los grandes", señalando que sólo los productores con "espalda" financiera pueden guardar la cosecha.

Conforme lo analizado en los capítulos anteriores, Página 12 aborda el modelo productivo sojero desde una mirada integral; informando sobre aspectos económicos, políticos, sociales, sanitarios y ambientales. El mismo periódico que en el rubro Economía reconoce la importancia de los millones de dólares provenientes de los agronegocios, cuando destaca que "permitieron reducir el 
impacto de los pagos de deuda" (08/04/2014); en el rubro Sociedad denuncia la existencia de conflictos sociales a causa del avance de la frontera agropecuaria e informa sobre casos de daños a la salud por el mal uso de productos fitosanitarios. Página 12 complejiza la realidad y tematiza sobre sectores vulnerables: campesinos que sufren el desalojo de "sus tierras", alumnos de escuelas rurales que fueron rociados con fitosanitarios, vecinos del barrio Islas Malvinas de Córdoba que se oponen a la instalación de una planta almacenadora de semillas. A diferencia de la centenaria publicación donde prevalece un abordaje económico, que asocia a la soja con la idea de mercancía, y se omite todo tipo de conflictos sociales. En este sentido, podría decirse que para el diario La Nación las únicas pérdidas generadas en el modelo sojero son las cuantificables; es decir, las que poseen valor monetario.

Puede concluirse que La Nación promueve el modelo hegemónico de producción agropecuaria argentina; es decir, el modelo sojero, basado en paquetes tecnológicos, semillas genéticamente modificadas, innovación en el sistema de labranza mediante la siembra directa, trabajo calificado y productos fitosanitarios; entre ellos, el glifosato.

De igual modo, reprodujo en sus páginas las ideas de la Mesa de Enlace, de las empresas multinacionales que elaboran eventos y variedades de semillas genéticamente modificadas y de las compañías encargadas de la exportación de cereales; haciendo eco de sus intereses de grupo y adhiriendo a sus reclamos. A lo largo del trabajo hemos visto, por ejemplo que la centenaria publicación señala que el sector rural se encuentra "afectado por la inflación", se declara a favor del pago de regalías a los dueños de las patentes de semillas y variedades biotecnológicas, y califica como elevados a los derechos de exportación.

Igualmente, promueve a través de "publinotas" la comercialización de las variedades de semillas de soja de Don Mario, Nidera y Syngenta; compañías que publicitan con frecuencia en el suplemento Campo y que auspician las ferias- remates de La Nación Ganadera, emprendimiento organizado por el periódico homónimo.

En la UA 5 resalta información positiva sobre la nueva tecnología propuesta por la compañía Syngenta y alega que la utilización de su paquete permitirá que los productores adquieran granos gruesos de soja y de maíz, y mayores rindes. Mientras que en la UA 7, la centenaria publicación señala que los altos rindes en lotes del centro sur de Santa Fe y el sudeste cordobés fueron posibles debido al uso de las nuevas variedades de semillas de Don Mario, Nidera y Syngenta. Y, 
en la UA 41 destaca los atributos de la nueva semilla Intacta presentada por la firma Nidera en el campo experimental El Recuerdo, en la localidad bonaerense de Venado Tuerto.

Para promover el modelo de producción sojero, La Nación efectuó una doble estrategia basada en destacar la palabra del sector agroexportador y omitir las voces de otros sectores que integran la ruralidad. Como veremos en el apartado de las fuentes, los reclamos del "otro" campo denominación utilizada por Página 12- no llegan a sus páginas. Esta operación configura la idea de un "campo" homogéneo, cuyos intereses están representados en la Mesa de Enlace.

Según la organización internacional GRAIN, los medios de comunicación corporativos, que actúan como brazo comunicacional del agronegocio, estigmatizan y criminalizan a los movimientos y organizaciones sociales que luchan contra el avance sojero, mostrándolos como subversivos o violentos, como se citó al inicio de este trabajo. La presente investigación pudo demostrar que en el diario La Nación, la protesta no es criminalizada sino que es omitida, dejando al margen de su agenda las luchas sociales de resistencia campesina que se suceden a lo largo del país y que son abordadas por Página 12.

Otra diferencia sustancial es que la centenaria publicación focaliza sus discursos en el modelo de los agronegocios y deja de lado el modelo de agricultura familiar. Mientras que Página 12 admite la existencia de estas dos economías y también reproduce los reclamos del segundo sector. Pudo observarse que el tabloide presenta el siguiente campo de lexemas relacionados con el agronegocio: "privatización de las semillas", "grandes empresas", "Monsanto", "extractivismo", “desalojos", "fumigaciones", "pooles de siembra”, "soja y maíz transgénicos”, "asesinato" y "poderosos". Mientras que los léxicos relacionados a los campesinos son: "semillas criollas", "soberanía alimentaria", "afectados", "reflexión, unión y lucha", "trabajo conjunto de organizaciones campesinas", “agricultura familiar", "resistiendo", "reforma agraria”, "producción agroecológica" y “alimentos sanos".

\section{Fuentes}

Según la clasificación de Lucrecia Escudero, La Nación empleó la mayor de las veces, fuentes textuales institucionales oficiales, pertenecientes a miembros de instituciones tradicionales del poder político y social. Las voces provenientes de la Mesa de Enlace representan las de mayor intervención (24\%); sobresalen aquí las consultas a los referentes de la Sociedad Rural Argentina 
con 12 declaraciones; seguidas de los testimonios de representantes de las Confederaciones Rurales Argentinas (CRA), con 5 declaraciones; a continuación la Federación Agraria Argentina (FAA), con 4 intervenciones y finalmente Coninagro, con 3 declaraciones. Las cuatro entidades de la Mesa de Enlace, en general, expresan información negativa sobre el Gobierno Nacional, a quien acusan de llevar adelante "desacertadas políticas macroeconómicas" y victimizan al sector agropecuario por el pago de retenciones, la inflación, el costo de los insumos que se importan y el dólar "blue".

En segundo lugar, se consultó a un conglomerado de fuentes conformado por mercados, bolsas, cámaras y asociaciones (18\%) que brindaron información sobre las cotizaciones de la soja a nivel nacional e internacional. En tercer lugar aparece la palabra de empresas ligadas a la biotecnología y agroindustrias (10\%); entre ellas, Nidera, ArgenBio, Dow Agrosciences, Syngenta, Don Mario, Sursem y el empresario agroindustrial Gustavo Grobocopatel.

A continuación, se detallan las demás fuentes consultadas por la centenaria publicación:

- Consultoras privadas y analistas (8\%), que en general describen un panorama negativo sobre la situación económica del sector agropecuario.

- Gobierno Nacional (6\%), cuyas declaraciones son reproducidas para polemizar y contraponerlas con otras voces.

- Distintos sectores con fines educativos/instructivos (5\%). Este conglomerado está conformado por expertos y productores que comentaron sus experiencias sobre los rendimientos de la oleaginosa (empresarios rurales; productores, ingenieros del grupo CREA y de la Universidad del Litoral).

- Instituciones y referentes que destacan el papel de los OGM (5\%).

- Sectores ecologistas y en defensa del ambiente (4\%), que mencionan los casos de los desmontes en la región conocida como el Gran Chaco Americano y de las inundaciones en el delta del Paraná.

- Y, en último lugar, una asociación de productores que no está nucleada en la Mesa de Enlace: el Movimiento Nacional Campesino Indígena (1\%).

Siguiendo con la clasificación de Escudero, La Nación emplea además fuentes oficiosas activas (5\%) que presentan un grado de identificación aceptable que las inscribe en un universo referencial específico: "en el sector agropecuario coinciden”, "el responsable comercial de una 
firma de granos", "una fuente de la Cámara de la Industria Aceitera", "una fuente de la cerealera Dreyfus". Según Escudero, estas fuentes vuelven "muy difícil la verificación de la información suministrada pero al mismo tiempo arrojan sobre la escena informativa datos y personajes con el objetivo de hacerlos circular" (1996: 110).

También aparecieron, aunque en menor medida agencias de noticias (4\%), medios de comunicación $(3 \%)$, productores que no están nucleados en asociaciones (3\%) y la Red Social Twitter $(2 \%)$.

Por su parte, Página 12 priorizó como fuentes a sectores ecologistas y en defensa del ambiente $(23 \%)$ que denuncian, por ejemplo, el uso de agroquímicos a escasos metros de escuelas rurales, incumpliendo la normativa vigente. En segundo lugar, le otorgó la palabra a asociaciones de productores que no están nucleadas en la Mesa de Enlace (14\%) que, entre otras cosas, denuncian desalojos, represiones y asesinatos a causa del avance de la frontera agropecuaria. En tercer lugar, a referentes del Gobierno Nacional (12.8\%) que brindan detalles sobre las políticas implementadas. Recién en cuarto lugar aparece como fuente la Mesa de Enlace y las asociaciones que la integran (10\%). El tabloide también le otorgó la palabra a Universidades $(8.9 \%)$ que a través de estudios e investigaciones aportan datos sobre temas sanitarios, sociales y ambientales relacionados con la soja. El conglomerado conformado por mercados, bolsas, cámaras y asociaciones aparece en sexto lugar (5\%) para informar sobre los precios de la oleaginosa. En séptimo lugar aparecen instituciones en defensa de los derechos humanos (5\%), empresas ligadas a la biotecnología (4\%)y corrientes y agrupaciones (4\%). Seguidamente, se utiliza como fuentes a la Cátedra Nacional de Economía Arturo Jauretche (2.5\%) y a entidades bancarias (2.5\%). Finalmente a una consultora privada (1\%). Todas ellas brindan datos positivos sobre la situación del agro.

Teniendo en cuenta la clasificación de Escudero, hasta aquí se trata de fuentes textuales institucionales oficiales.

También aparecen declaraciones de vecinos en contra de las fumigaciones (4\%), una fuente oficiosa activa (1\%) y se consulta a la red social Twitter (1\%).

A fin de exponer información de manera visual, los siguientes cuadros sintetizan las fuentes utilizadas por ambos diarios: 


$\begin{array}{lc}\text { FUENTES LA NACIÓN } & \text { Porcentaje } \\ \text { Mesa de Enlace } & 24 \% \\ \text { Mercados, bolsas, cámaras y asociaciones } & 18 \% \\ \text { Empresas ligadas a la biotecnología y agroindustriales } & 10 \% \\ \text { Consultoras privadas y analistas } & 8 \% \\ \text { Gobierno Nacional } & 6 \% \\ \text { Instituciones y referentes que destacan el papel de OGM } & 5 \% \\ \text { Distintos sectores con fines educativos/instructivos } & 5 \% \\ \text { Fuentes oficiosas activas } & 5 \% \\ \text { Sectores ecologistas y en defensa del ambiente } & 4 \% \\ \text { Agencias de noticias } & 4 \% \\ \text { Medios de comunicación } & 3 \% \\ \text { Productores } & 3 \% \\ \text { Red social (Twitter ) } & 2 \% \\ \text { Asociaciones de productores que no están nucleadas en la Mesa de Enlace } & 1 \%\end{array}$

$\begin{array}{lc}\text { FUENTES PÁGINA } 12 & \text { Porcentaje } \\ \text { Sectores ecologistas y en defensa del ambiente } & 23 \% \\ \text { Asociaciones de productores que no están nucleadas en la Mesa de Enlace } & 14 \% \\ \text { Gobierno Nacional } & 12.8 \% \\ \text { Mesa de Enlace } & 10 \% \\ \text { Universidades } & 8.9 \% \\ \text { Mercados, bolsas, cámaras y asociaciones } & 5 \% \\ \text { Instituciones en defensa de Derechos Humanos } & 5 \% \\ \text { Empresas ligadas a la biotecnología } & 4 \% \\ \text { Corrientes y agrupaciones } & 4 \% \\ \text { Vecinos en contra de las fumigaciones } & 4 \% \\ \text { Cátedras } & 2.5 \% \\ \text { Entidades bancarias } & 2.5 \% \\ \text { Consultora privada } & 1 \% \\ \text { Fuente oficiosa activa } & 1 \% \\ \text { Red social (Twitter ) } & 1 \%\end{array}$




\section{Imágenes}

En lo referente a las fotografias, en ambos diarios predominan imágenes documentales que adhieren a la realidad en sus conexiones esenciales, como señala Thibault Laulan. De las 15 imágenes que presenta el diario La Nación, 12 son documentales y de las 22 que posee Página 12 , 18 corresponden a igual categoría.

La centenaria publicación también presenta dos "fotos pose" en las que se retrata a Roberto Levingston, un productor de la zona de El Trébol, Santa Fe, rodeado de una plantación de la oleaginosa que obtuvo altos rindes (UA 7) y a Gustavo Grobocopatel, ingeniero agrónomo que conduce una de las principales compañías agropecuarias del país, junto a su esposa Paula Marra en Expoagro (UA 28). Según Verón, en este tipo de imágenes, el personaje ofrece su imagen al fotógrafo.

En este periódico aparecen además, dos fotografías correspondientes a lo que Verón llama "retórica de las pasiones" por haber sido "arrancadas" a los personajes cuando su rostro expresaba una emoción, en donde aparecen las fotografías de Luis Miguel Etchevehere, presidente de la SRA y la de Ricardo Echegaray, titular de la AFIP.

De igual modo, La Nación presenta un cuadro con las cotizaciones en alza de los granos a término en el país y en el exterior (UA 10) y dos gráficos a color, que exhiben información estadística sobre la reducción de hectáreas sembradas de trigo, girasol y centeno, el primero, y sobre el descenso de toneladas de carne exportadas en el periodo que comprende los años 2005 a 2013, el segundo. Dichos gráficos actúan como editoriales porque el medio los elabora con la intención de impactar visualmente al lector con información negativa acerca de la situación económica del campo (UA 29).

Por su parte, Página presenta tres imágenes apelativas utilizadas para impactar al perceptor. Dos de ellas corresponden a fotomontajes ubicados en portadas; uno en el que aparece un grifo por el que caen granos de soja (UA 27) y otro que consiste en un contador o ábaco (instrumento para hacer cálculos manualmente) que en vez de cuentas redondas posee semillas de soja, ubicado sobre un montículo de semillas y de las chauchas que las contienen (UA 36). Dichas imágenes responden al estilo creativo e innovador que caracteriza al periódico creado en la década del '90. También se empleó una caricatura (UA54) en la que se ironiza sobre los intereses económicos de los grandes agricultores y sobre los daños ambientales causados por la deforestación. Mientras 
que en la UA 23 aparecen dos fotografías de Carlos Casamiquela, ministro de Agricultura de la Nación, que corresponden a lo que Verón llama "retórica de las pasiones", ya que fueron arrancadas al personaje durante una entrevista.

\section{Ejes temáticos}

A fin de brindar un panorama completo sobre el objeto de estudio se describirán los hallazgos de los diez ejes temáticos en los que se clasificó el corpus:

\section{III.1. La rentabilidad del modelo agrosojero.}

En el eje temático $N^{\circ} 1$ "La rentabilidad del modelo agrosojero", el diario La Nación describió a la soja en términos de intercambio desfavorables. El 9 de febrero de 2013 (UA 1) informó que en la campaña 2012/ 2013 se deterioró el poder de compra de la soja respecto al ladrillo. Mientras que en igual periodo, Página 12 publicó la noticia titulada "La siguen cosechando con pala" (UA 2), en donde alude a la rentabilidad del sector sojero y desmiente el relato de los empresarios del agro sobre una "supuesta crisis".

Para el tabloide, el sector agropecuario aparece asociado con las siguientes palabras que señalan el buen momento económico que atraviesa: "rentabilidad", "evolución de los precios", "ganancias", "negocio muy rentable", “aumento", "fuerte suba", "bonanza" e "inversión”. En contraposición con la centenaria publicación que utiliza adjetivos evaluativos no axiológicos para señalar de manera latente que el productor se encuentra perjudicado debido a "Elevados impuestos (35\% derechos de exportación)" y a "una inflación doméstica en bienes de construcción excepcionalmente alta (promedia el 25\% anual entre 2009 y 2012)”.

Pudo notarse además, que el diario La Nación plantea escenarios disímiles para el agro en sus discursos; uno caracterizado por la inflación y los elevados costos de los insumos y otro, donde informa que será récord la cosecha de soja y anuncia mejoras en las cotizaciones en la Bolsa de Chicago. Por un lado, predica que el sector rural se encuentra "afectado por la inflación" (UA 6) y predice que con la escalada del dólar paralelo llevada a cabo en marzo de 2013 los productores se verán afectados por los dos tipos de cambio del dólar (oficial y blue) a la hora de comprar insumos, debido a que "a las empresas proveedoras se les podría hacer más cara y complicada la reposición de productos" (UA 3). Y, por otra parte, informa que "el precio de la soja subió por 
tercera consecutiva" (UA 9) y que según el Ministerio de Agricultura de la Nación, "las primeras evaluaciones permiten estimar una producción de soja de 51, 30 millones de toneladas" (UA 4).

\section{III.2. Las patronales.}

Teniendo en cuenta la estrategia de fondo de las relaciones de conflicto que plantea Prieto Castillo, Página 12 reconoce una relación de oposición entre la Mesa de Enlace y el Gobierno; a diferencia de La Nación que construye la idea de conflicto entre el "campo", como sector homogéneo y el Gobierno. Como pudimos observar en diferentes unidades de análisis, para el diario La Nación la totalidad del sector agrario se encuentra representado en las cuatro entidades que conforman la Comisión de Enlace de Entidades Agropecuarias (CEEA): la Sociedad Rural Argentina, las Confederaciones Rurales Argentinas (CRA), la Federación Agraria Argentina (FAA) y la Confederación Intercooperativa Agropecuaria Limitada (Coninagro). Cuando el campo está conformado también por agricultores familiares, pueblos originarios, cooperativas, etc., nucleados a su vez en otras asociaciones.

Por su parte, Página 12 reconoce la existencia de un campo que posee diferentes estratos y realidades: pequeños, medianos y grandes productores:

- "Página/12 habló con varios productores sojeros, pequeños, y les consultó si estaban dispuestos a vender soja con el actual tipo de cambio. La respuesta fue que ellos no tenían los granos, sino que ya habían sido vendidos a los exportadores”.

- "Los pequeños y medianos productores no tienen capacidad de mantener en silos y silobolsas su producción. Generalmente venden cuando van sacando cosecha. Quien tiene stock de soja cuenta con una espalda financiera importante" (Casamiquela).

Pudo observarse además, que Página 12 utiliza las figuras retóricas de la paradoja (A) y de la ironía (B) para plantear que existe una contradicción entre la realidad del sector productivo y el discurso de la Mesa de Enlace que alega una crisis:

A) (La exposición Rural) "Abre las puertas con cosecha y quejas récord".

B) "El dirigente de la SRA, como el resto de los integrantes de la Mesa de Enlace, viene repitiendo desde hace cinco años el mismo latiguillo: 'El campo no da para más'”. Y, seguidamente, el tabloide refuta este argumento señalando que, "la cosecha 2012-2013 
alcanzó un record histórico, con 105 millones de toneladas, donde se destacaron el maíz, la soja y la cebada" (UA 17).

Vimos además que en Página 12 los productores que llamaron a no vender soja aparecen categorizados en función de su situación e intereses económicos, como: "terratenientes nucleados en la Mesa de Enlace", "férreos opositores", "socios de la Rural", "clase terrateniente" y “oligarquía dueña de la soja". Además, se los asocia negativamente a los términos: "boicot", “concentración" y se los responsabiliza de querer generar un "desgobierno". Mientras que para mencionar a las empresas exportadoras se utilizan términos relacionados a su potencial económico: "multinacionales", "grandes exportadores" y "corporaciones". Y, se las asocia de manera negativa con barajar "la posibilidad del lockout".

\section{III.3. La política económica del Gobierno Nacional.}

A lo largo de este y otros eje temáticos, pudimos observar que el diario La Nación enfatizó información negativa sobre el Gobierno de la Nación y sus políticas agropecuarias, como puede observarse en el siguiente mapa de predicaciones:

\section{Gobierno Nacional}

- "Prefirió perjudicar al campo".

- Puso "trabas" a la comercialización de productos.

- “... para los principales productos del campo la 'década ganada' de gobiernos kirchneristas quedó trunca".

- “...obliga a los productores a vender por medio de aprietes y actos intimidatorios".

- "Persigue" a los productores.

- Está "preocupado en un año electoral".

- “... da la espalda a los reclamos” del sector.

- “... quiere controlar todo lo que sea industria, comercio y producción..."

- “... posee una actitud de revanchismo hacia el sector agropecuario".

- “... comenzó a analizar la ley antiterrorista para presionar a exportadores y productores a vender soja ante la escasez de divisas". 
El Gobierno también aparece asociado a los siguientes léxicos negativos que reflejan juicios de valor del enunciador respecto al tema: "fascismo", "crisis cambiaria", "apriete” y "embestir". Mientras que la AFIP está ligada a estos términos: "control”, "volvió a la carga", "ofensiva", “presión” e “intimidación”. El Indec, por su parte, está ligado al término negativo "trucho".

De igual manera, La Nación empleó en sus discursos la figura retórica de la metáfora para descalificar al Gobierno y para describir en términos negativos la situación económica del país, luego de la última devaluación del peso oficial en enero de 2014:

- "Lo cierto es que hay un ambiente de temor generalizado a sacar la cabeza ya sea por sufrir alguna persecución de la AFIP, por la inseguridad privada o por mostrarle la muleta del torero al Gobierno como para que embista con nuevas retenciones" (UA 21).

- "El Gobierno volverá a desplegar hoy una de sus jugadas más repetidas en medio de la tormenta cambiaria" (UA 25).

En este eje temático pudo advertirse además, que el diario La Nación jerarquizó en el título de una noticia (UA 28) la palabra del empresario agroindustrial, Gustavo Grobocopatel, con una cita en donde señala que de alguna manera no existe una buena relación entre el campo, como unidad homogénea y el Gobierno: “El próximo gobierno debe mejorar la relación con el campo...”.

\section{III.4. Los controles de la AFIP.}

En Página 12, la AFIP aparece asociada a la lucha contra el trabajo esclavo e infantil y contra la evasión fiscal de productores y empresas cerealeras. En este periódico se resalta el accionar del organismo encargado de ejecutar las políticas impulsadas por el Poder Ejecutivo Nacional en materia tributaria y aduanera. Por ejemplo, la UA 32, destaca de manera positiva que a pedido de la AFIP, la Justicia realizó 27 allanamientos "en distintas compañías cerealeras sospechadas de utilizar empresas 'fantasma' para ingresar al mercado formal de granos no declarados”.

Por su parte, el periódico La Nación asocia a la AFIP con los siguientes léxicos negativos: "persecución”, "agresivas y amenazantes", "apriete”, "redobló el control”, "volvió a la carga", "ofensiva", "presión", "violación a la propiedad privada" e "intimidación"; que conllevan a pensar en la idea de un organismo encargado de hostigar a los productores rurales presionando para la venta de soja. 
En lo que respecta al registro electrónico implementado por la AFIP para declarar la existencia de granos almacenados, pudo observarse que fue objeto de múltiples acentuaciones; es decir que, como señala Bajtín, se trata de un signo pluriacentuado. Página 12 lo describió como una medida que "servirá al Estado para combatir la evasión y maniobras especulativas"; mientras que para La Nación "profundizará el control sobre la comercialización de la cosecha" y con ella "habría más costos para los operadores".

\section{III.5. Organismos Genéticamente Modificados.}

En este eje temático pudo observarse que La Nación reproduce la palabra de empresas que solicitan la sanción de una ley de semillas que contemple el pago de regalías cada vez que los productores utilicen semillas genéticamente modificadas y omite los argumentos de otros sectores en defensa de las semillas nativas y criollas. Mediante la palabra ajena también se construye la idea de que los transgénicos no ocasionan daños a la salud y además reducen el impacto ambiental de la agricultura ya que con ellos se utiliza menor cantidad de agroquímicos.

De igual modo, la centenaria publicación asocia a la biotecnología con la idea de productividad y de competitividad.

En lo que respecta a la semilla de Monsanto, Intacta RR 2 Pro, Página 12 -al igual que La Nación- reconoce los atributos del producto pero aborda el tema desde una mirada más compleja y también otorga la palabra a referentes de sectores ambientalistas que denunciaron ante la Justicia Federal que es "irregular" la forma en que fue aprobada la nueva semilla del agro. Como pudo verse en la UA 43: "Fernando Cabaleiro, del Celma, cuestionó el rol de la Comisión Nacional de Biotecnología Agropecuaria (Conabia) y del Senasa (Servicio de Sanidad y Calidad Agroalimentaria). 'Se basan sólo y exclusivamente en los estudios realizados por la propia firma solicitante, Monsanto. No existe ninguna observación ni pregunta sobre los trabajos presentados por la empresa', afirmó el abogado y señaló que en la foja 37, documento de decisión con el que la Conabia aprobó la nueva soja, se visualizan `once garabatos-firmas, sin aclaración de nombres, especialidad ni cargos. Pudo ser cualquiera. Es insólita la impunidad con la que dan luz verde a una semilla que abarcará millones de hectáreas', cuestionó”. 
En Página 12, La palabra del "otro" también expresa opiniones en contra de la ley de semillas que impulsan las transnacionales del agro (UA 42) y de la instalación de "una planta de semillas transgénicas en Malvinas Argentinas", provincia de Córdoba.

Teniendo en cuenta el cuadrado ideológico propuesto por van Dijk, la UA 44 enfatiza información negativa sobre Monsanto y sobre el Gobierno provincial de José Manuel de la Sota, al señalar que la empresa incumplió la realización del estudio obligatorio de impacto ambiental, establecido en la Ley General del Ambiente y que el Ejecutivo provincial tampoco se lo exigió. Agrega además, que el intendente Daniel Arzani (UCR) y el gobernador de la Sota (PJ) rechazaron la iniciativa de la Asamblea de Vecinos Malvinas Lucha por la Vida, que en noviembre de 2012 comenzó a exigir que la realización de un plebiscito en el que la población pudiera votar a favor o en contra de la instalación.

Pudo observarse también, que en Página 12 la empresa Monsanto, aparece relacionada a la figura de victimario, a través de las siguientes predicaciones: “impulsa la aplicación de millones de litros de agrotóxicos, expulsa campesinos, destruye el ambiente y la soberanía alimentaria y daña la salud de miles de personas" y comete "excesos contra la naturaleza, los agricultores y los consumidores".

Otra diferencia en el tratamiento informativo de los diarios seleccionados tiene que ver con la diagramación y jerarquización del acontecimiento. Recordemos que Página 12 anunció la nueva semilla de soja de Monsanto "Intacta RR2" en dos columnas y 17 líneas que ocuparon el extremo inferior de la página 7, en su edición del 22 de agosto de 2012. Acontecimiento que pasa casi inadvertido al ocupar alrededor del $12 \%$ de la mencionada página; a diferencia de La Nación que jerarquizó las notas sobre la aprobación de la nueva variedad de soja, ubicando el hecho en la tapa del suplemento Campo (25/08/2012) y ocupando la totalidad de la página 6 de dicho segmento.

Finalmente, cabe señalar que sólo en una ocasión el diario de los Mitre realizó un juicio de valor positivo sobre el Gobierno Nacional refiriéndose a las gestiones realizadas en materia biotecnológica y a los "eventos" aprobados en el país para su comercialización: "Es, tal vez, la única política acertada que ha tenido el kirchnerismo en la relación con el campo, luego de destruir con su intervención los mercados de carne, trigo y leche” (UA 38). Sin embargo, culmina la idea señalando información negativa sobre el Ejecutivo. 


\section{III.6. Los silobolsas.}

Otra diferencia significativa en las construcciones que realizan los periódicos es que, para Página 12 los productores retuvieron soja porque especularon con la devaluación del peso oficial, como señala en la UA 13: "Según un informe de la Cámara de la Industria Aceitera, al 24 de febrero se había liquidado un 30 por ciento menos de divisas que hace un año. Esto obedeció a cierta especulación por parte de los productores y la industria vinculada con los movimientos en el tipo de cambio". Mientras que el periódico de los Mitre interpreta que los productores de soja retienen la comercialización de la oleaginosa "para hacer frente a inversiones como la siembra de trigo y otros gastos relacionados con su actividad" (UA 20); es decir, que la utilizan como un ahorro.

La hipótesis de especulación aparece también en la UA 23, cuando el diario Página 12 toma como principal fuente de la noticia, las palabras del ministro de Agricultura de la Nación y en la UA 45:

- "El ministro de Agricultura, Carlos Casamiquela, cuestionó en diálogo con Página/12 a la dirigencia agropecuaria y a los exportadores por llevar adelante una estrategia de especulación, al no vender su producción, con el objetivo de erosionar al gobierno nacional" (UA 23).

- "Los productores no esperan mejores precios, sino que especulan con que se relajen los controles oficiales o encontrar algún artificio legal que les permita volver a atesorar dólares. En este caso, los silobolsas, un invento argentino que es aprovechado por sólo cuatro firmas que además exportan a casi todos los países productores de granos, se convierten en cajas fuertes de lo que consideran un bien que puede liquidarse fácilmente" (UA 45).

En lo referente a la lexicalización o palabras escogidas para expresar un concepto, La Nación denomina a la cosecha sin liquidar "granos que no se vendieron hasta el momento" y "granos almacenados". A diferencia del diario Página 12 que emplea la expresión "cosecha retenida", que posee connotaciones negativas, ya que este verbo implica interrumpir o dificultar el curso normal de algo. En términos bajtianos, podríamos decir que cada periódico utiliza palabras con diferente “acentuación ideológica” para referirse a la producción que no se comercializa.

Por otra parte, Página 12 señala que, "En el Gobierno estudian cómo incentivar a productores de soja para que liquiden los granos guardados en silobolsas"; a diferencia del diario La Nación para 
quien el Gobierno "presiona" a los productores para que liquiden. Como puede observarse, estos diarios dan versiones totalmente opuestas sobre el accionar del Gobierno. Mientras Página 12 predica de manera positiva, La Nación asocia al Gobierno con el uso de la fuerza.

Hemos señalado además, que La Nación publica dos noticias sobre la rotura de ocho silobolsas en las que un productor de la localidad bonaerense de 9 de Julio almacenaba soja (UA 46 y 47) y asocia el hecho con una ofensiva de la Casa Rosada contra el sector rural. Mientras que el diario Página 12 omite esta información.

\section{III.7. Los costos sociales del modelo agrosojero.}

A lo largo del estudio pudo observarse que Página 12 relaciona el avance de la frontera agropecuaria por la siembra de soja con los conflictos por tenencia de tierras, hecho que no aparece mencionado en el diario de los Mitre pese a que en nuestro país existen unas 9,3 millones de hectáreas en disputa y 64.000 familias campesinas e indígenas afectadas, según datos del Ministerio de Agricultura de la Nación (UA 52). Los conflictos por la propiedad de las tierras ni siquiera son mencionados cuando La Nación anuncia el asesinato del campesino indígena Miguel Galván por resistirse a abandonar la tierra donde vivía (UA 49), noticia en la que se relaciona el crimen con las denuncias sobre la tala indiscriminada.

La centenaria publicación tampoco menciona la existencia de un proyecto presentado por el Movimiento Evita para suspender por cinco años los desalojos "de campesinos que se ven afectados por el corrimiento de la frontera agrícola a partir de los agronegocios", como informa el tabloide.

De igual modo, Página 12 señala que muchos campesinos "sufrieron desalojos de sus tierras, más allá de estar amparados por la ley veinteañal, que indica que si una persona o familia habita por más de veinte años un campo para su subsistencia, tiene derecho de posesión sobre el mismo" (UA 51). Con lo cual señala de manera implícita la ilegalidad de los desalojos al incumplir una norma que ampara el uso de las tierras por parte de los campesinos.

El análisis de este eje temático permitió dilucidar también que para Página 12 el avance de la frontera agropecuaria por la siembra de soja es la causa de la violencia ejercida contra los campesinos en Santiago del Estero, donde asesinaron a Galván: 
"Represión, amenazas, desalojos, causas armadas, detenciones arbitrarias, golpizas e intentos de homicidio son sólo algunas de las prácticas de amedrentamiento utilizadas por empresarios en complicidad con jueces y policías provinciales. El problema, aseguran desde las organizaciones sociales, ha recrudecido principalmente en el norte de la provincia, donde tierras que no resultaban productivas para la siembra cobraron valor con la llegada de los agroquímicos y el boom de la soja", señala el diario nacional en la UA 50.

En cuanto al uso de subjetivemas, Página 12 califica a los conflictos de Santiago del Estero como graves y a los asesinatos como trágicos. Mediante estos evaluativos axiológicos el enunciador manifiesta un juicio de valor negativo acerca de la situación:

- "El asesinato de Ferreyra, el 16 de noviembre de 2011, evidenció la gravedad de los conflictos en la zona".

- "No fue el único caso que casi termina en tragedia".

Cabe destacar además, que Página 12 otorga la palabra a organizaciones de productores que no se encuentran nucleados en la Mesa de Enlace y reproduce sus reclamos; entre ellos, la regularización de la posesión de tierras, la defensa por las semillas criollas y la soberanía alimentaria. Mientras que en La Nación estos temas son omitidos.

Teniendo en cuenta las proposiciones de van Dijk, pudimos observar también que en Página 12 las comunidades campesinas e indígenas de Santiago del Estero están asociadas a la idea de víctimas que "sufren" nuevamente una "escalada de violencia"; a diferencia de La Nación que construye la idea de víctimas en torno a los productores nucleados en la Mesa de Enlace, que se encuentran en "crisis" debido a las políticas económicas implementadas por el Gobierno de Cristina Kirchner, como vimos por ejemplo en la UA 21:

- "Los chacareros saben que vienen perdiendo poder de compra año a año".

- "La primera víctima de este ambiente donde nadie quiere ser destacado es la producción. Se encuentra afectado el mismísimo espíritu del que produce, que tiene que lidiar ya no con un Estado convertido en el 'socio bobo', como lo suele describir el dirigente Néstor Roulet al mencionar que con las retenciones sólo comparte las ganancias, sino con un Estado policial". 


\section{III.8. La tala de árboles.}

Este eje temático no aparece con asiduidad en los periódicos que forman parte de la investigación, teniendo en cuenta que en el periodo de estudio sólo se publicaron 4 noticias en Página 12 y 1 en La Nación, seleccionándose 2 unidades del primer diario y la publicada en el segundo.

No obstante, podemos señalar algunas diferencias en la construcción de los acontecimientos. Entre ellas, que Página 12 jerarquiza las noticias al ubicarlas sobre la denominada línea de indicatividad y al otorgarles espacios extensos (más del 50\% en las páginas correspondientes a las UA 53 y 54). Mientras que en La Nación la tala de árboles pasa casi inadvertida en una noticia que solamente ocupa el 10\% del extremo inferior izquierdo de la página 15 en la edición del 30 de julio de 2014 (UA 55).

Si bien los dos periódicos señalan el corrimiento de la frontera agropecuaria por cultivos de soja como la causa de los desmontes; La Nación presenta un discurso de baja referencialidad en el cual ofrece unas pocas notas de algo, con la intención de que con ellas se agote todo. Mientras que Página 12 otorga versiones de alta referencialidad, que acercan lo más posible al tema, mediante una adecuada cantidad de información y detalles precisos sobre la tala de árboles.

Pudimos observar que en la UA 53, Página 12 tomó como principal fuente un informe de la Defensoría del Pueblo que opera como voz autorizada y resalta información negativa sobre el avance de la frontera agrícola:

- "El corrimiento de la frontera agropecuaria implica la violación de derechos de campesinos y comunidades indígenas. Lo afirmó la Defensoría del Pueblo de la Nación en su último informe sobre la situación rural en el nordeste de Salta, donde constató desmontes en zonas prohibidas, violencia sobre comunidades, incumplimiento de leyes nacionales y provinciales, falta de control por parte del gobierno provincial y la ausencia del Instituto Nacional de Asuntos Indígenas (INAI)”.

Teniendo en cuenta el uso de subjetivemas, pudo observarse que en Página 12 aparece en reiteradas ocasiones el adjetivo afectivo "afectadas" para caracterizar a las poblaciones rurales que padecen los efectos de las deforestaciones. A partir del empleo de este adjetivo subjetivo y de otras descripciones, se induce que los pobladores son considerados víctimas:

- "El trabajo comenzó con visitas a las comunidades afectadas...". 
- "Las comunidades afectadas denuncian que las autoridades no hacen nada para frenar el desmonte".

- “... para implementar un sistema de monitoreo que detecte la deforestación en tiempo real y que pueda ser gestionado por las propias comunidades afectadas”.

- "Se ha verificado una clara vulneración a los derechos de pobladores criollos e indígenas, un potencial daño al medio ambiente, debilidad en el accionar de la provincia para la solución de los hechos observados y la existencia de un conflicto social latente, que demanda la urgente atención por parte de todas las autoridades con el fin de evitar una escalada que produzca consecuencias imposibles de remediar', alertó la Defensoría del Pueblo" (UA 53).

\section{III.9. La contaminación del medio ambiente.}

Como señalamos antes, en el periodo comprendido entre agosto de 2012 y julio de 2014, los diarios no enfatizaron en esta temática, a diferencia de otras más desarrolladas que requirieron de la selección de noticias por parte de la investigadora para formar parte de la muestra. El único discurso publicado por el diario La Nación que se relaciona con el eje temático número 9 corresponde a la noticia titulada "El delta del Paraná se está volviendo ingobernable" (UA 56).

Cabe señalar que en el diario Página 12 no se encontraron noticias que se relacionen de manera exclusiva con este eje. El tema de la contaminación aparece mencionado en las UA 57, 58, 59 y 60 pero desde un enfoque sanitario en los seres humanos, sin profundizar en los efectos que provoca el mal uso de agroquímicos en el suelo, el agua y el aire.

La UA 56 denuncia que las construcciones urbanas y las plantaciones de soja provocan inundaciones en el Delta del Paraná y explica que el uso de herbicidas contamina el humedal; ecosistema considerado como reservorio de agua dulce para las poblaciones cercanas. Junto a la UA 55, son las únicas notas del diario La Nación en las que se mencionan efectos negativos del monocultivo extensivo; en los demás discursos que integran el corpus se brinda información positiva sobre la oleaginosa. 


\section{III.10. Los riesgos a la salud.}

Cabe destacar aquí que en el diario La Nación no se encontraron noticias relacionadas con este eje temático a diferencia del diario Página 12, que de un total de 11 noticias publicadas durante el periodo de estudio, se seleccionaron 4 para su análisis. Lo que conlleva a pensar en la importancia que le brinda cada periódico a la temática.

En las UA seleccionadas, Página 12 reproduce la palabra de sectores ambientalistas y médicos de las Universidades Nacionales de Córdoba, Río Cuarto y del Nordeste que denuncian la existencia de fumigaciones en campos de soja cercanos a zonas habitadas y sobre escuelas; y que solicitan entre otras cosas, evitar la instalación de la planta de acopio de Monsanto en la localidad de Malvinas Argentinas, respetar las distancias establecidas por Ley para fumigar y el cumplimiento de fallos judiciales y proponen sistemas de producción sustentables.

En este periódico, los agroquímicos son denominados "agrotóxicos"; término que posee connotaciones negativas y las fumigaciones en las plantaciones de soja están asociadas a los siguientes léxicos negativos que dan cuenta de los daños que ocasionan a la salud de la población: peligrosos, intoxicaciones, problemas respiratorios y gastrointestinales, enfermedad, nocivos, contaminación, cáncer, discapacidad, enfermedades, tumores, malformaciones congénitas, alergias, reducción de la fertilidad masculina, abortos espontáneos, afecciones en la piel, enfermedades neurológicas, reducción del crecimiento, anormalidades fetales, fatiga crónica en niños y mal de Parkinson.

Finalmente, teniendo en cuenta las proposiciones planteadas por van Dijk, en Página 12 los pobladores de las localidades cercanas a plantaciones de soja, girasol y arroz donde se fumiga, aparecen como víctimas o afectados por un modelo agropecuario que ocasiona consecuencias en la salud. 


\section{PARA SEGUIR INVESTIGANDO}

Sin dudas queda mucho por estudiar sobre el modelo productivo sojero en los medios argentinos. Este trabajo apenas describe y compara el tratamiento periodístico de dos diarios nacionales en un periodo de tiempo. No obstante podría actuar como disparador para futuras investigaciones donde se amplíen las unidades de análisis, se comparen distintos momentos históricos o aborden el objeto de estudio desde un marco teórico que incluya a otras disciplinas como la Historia, la Sociología y la Filosofía. Hasta aquí nuestro aporte al campo de la Semiótica, el Periodismo y la Comunicación, contribuyendo con herramientas para el necesario debate sobre el modelo agrario argentino. 


\section{APÉNDICE DOCUMENTAL}




\section{BIBLIOGRAFÍA}

- ÁlVAREZ, M. F. S.; (2009) Pocos ganan, muchos pierden: soja, agroquímicos y salud. Primera Edición. Eduvim, Departamento Río Segundo, Provincia de Córdoba, Páginas 28 - 55.

- ARFUCH, E.; (1997) Crímenes y pecados de los jóvenes en la crónica policial. Primera edición. UNICEF, Buenos Aires, Capítulo 4.

- ATORRESI, A.; (1996) Los estudios semióticos. El caso de la crónica periodística. Conicet, Red Federal, Buenos Aires, Capítulo III y IV.

- BAJTÍN, M.; (1992) Marxismo y filosofía del lenguaje. Alianza, Madrid, Primera parte Capítulo 1.

- BARSKY, O. y DÁVILA, M. (2008). La Rebelión del Campo. Historia del conflicto agrario argentino. Editorial Sudamericana, Buenos Aires, Página 68.

- BIDASECA, K.; (2013) Relevamiento y sistematización de problemas de tierra de los agricultores familiares en la Argentina. $1^{\circ}$ Edición. Ministerio de Agricultura, Ganadería y Pesca de la Nación, Secretaría de Desarrollo Rural y Agricultura Familiar, Buenos Aires, páginas 4, 10, 13, 48, 49 y 52.

- BORRAT, H.; (1989) El periódico, actor político. Editorial Gustavo Gili, Barcelona, Página 10.

- BRAVO, A.; CENTURIÓN MERELES, H y otros; (2010) Los señores de la soja. La agricultura transgénica en América Latina. Primera Edición. Fundación Centro de Integración, Comunicación, Cultura y Sociedad (CICCUS), Consejo Latinoamericano de Ciencias Sociales (CLACSO), Buenos Aires, Páginas de 10 a 21.

- CRUZATE, G. y CASAS, R.; "Extracción y balance de nutrientes en los suelos agrícolas de la Argentina"; Instituto de Suelos del INTA, 2012.

-DABAT, G. y PAZ, S.; (2013) Paradoja de la soja argentina. Modernización hacia el monocultivo. Primera Edición. Centro Cultural de la Cooperación, Buenos Aires.

- ESCUDERO, L.; (2000) Puente del alma: la emergencia de la subjetividad en el escenario mediático. En: Cuaderno de Información y comunicación. № 5, Universidad Complutense de Madrid, Madrid. Páginas 79- 97. 
- ESCUDERO, L.; (1996) Malvinas, el gran relato. Primera Edición. Gedisa, Barcelona, Capítulos 1 y 4.

- FILINICH, M. I.; (2001) Enunciación. Eudeba, Buenos Aires.

- GARCÍA, M.; (2004) Narración, Semiosis, Memoria. $2^{\circ}$ Edición. Editorial Universitaria de la Universidad Nacional de Misiones, Posadas, Páginas 66- 68.

- GRAS, C. y BIDASECA, K. (2010). El mundo chacarero en tiempos de cambio, Buenos Aires, Editorial CICCUS, página 6.

- GUDYNAS, E.; (2011) Más allá del nuevo extractivismo: transiciones sostenibles y alternativas al desarrollo. En: El desarrollo en cuestión. Reflexiones desde América Latina, Fernanda Wanderley. Oxfam y CIDES UMSA, La Paz, Bolivia, páginas 379- 410.

• HERNÁNDEZ, J., (2009) Martín Fierro. RTM S.A., Buenos Aires, página 17.

- HODGE, B.; (1983) Periódicos y Comunidades. En: Fowler, R. (ed.): Lenguaje y Control FCE, México, páginas $41-52$.

- JAURETCHE, A.; (2010) Política y Economía. $1^{\text {o }}$ Edición, Corregidor, Buenos Aires. página 30.

- LÓPEZ, M. S.; (1998). Fundamentos Epistemológicos y metodológicos del análisis del discurso. Aproximación al análisis discursivo como herramienta abductiva de las ciencias sociales. Editorial Universitaria de la Universidad Nacional del Nordeste; Corrientes.

- LOZANO, J.; PEÑA MARÍN, C. y ABRIL, G.; (1993) Análisis del discurso. Hacia una semiótica de la interacción textual. $4^{\circ}$ Edición; Ediciones Cátedra, Madrid.

- MENDICOA, G.; (2003) Sobre tesis y tesistas. Primera edición. Espacio Editorial, Buenos Aires, capítulos 4 y 5.

- MOCASE VC, Movimiento Campesino de Santiago del Estero- Vía Campesina; (2012) Memoria de los orígenes de la Central campesina de Quimilí. 1 ${ }^{\text {o }}$ Edición. Mocase VC, Santiago del Estero, página 99.

- ORECCHIONI, K.; La enunciación de la subjetividad en el lenguaje. Hachette, Francia, 1986. páginas 91 y 92.

- PÉREZ SERRANO, G.; (1994) Investigación cualitativa. Retos e interrogantes. II Técnicas y análisis de datos. Editorial La Muralla, Madrid, página 104. 
- PERETTI, P.; (2013) Chacareros, soja y gobernabilidad. Del Grito de Alcorta a la Resolución 125. $1^{\circ}$ Edición. Fundación CICCUS, Buenos Aires, Capítulos 1, 2 y 3.

- PETRANTONIO, M. y ARANGUREN, C.; (2008) El proceso de sojización: la mirada en un territorio desde una perspectiva histórica. Ponencia de las II Jornadas Nacionales de Investigadores de las Economías Regionales, Tandil.

- PRIETO CASTILlO, D.; (1999) El juego discursivo. Manual de análisis de estrategias discursivas. Lumen Hvmanitas, Buenos Aires.

- REDAF, Red Agroforestal Chaco Argentina, Observatorio de Tierras, Recursos naturales y medioambiente; (2010) Conflictos sobre tenencia de tierra y ambientales en la región del Chaco argentino. $2^{\circ}$ Informe datos relevados hasta agosto de 2010, Reconquista, Cap. 2 y 3.

- RODRÍGUEZ, J.; (2008) Consecuencias económicas de la soja transgénica. Argentina, 19962006. CLACSO, Buenos Aires, 2008, página 89.

-SABINO, C.; (1996). El proceso de investigación; Tercera Edición. Lumen, Buenos Aires, capítulos 6, 7, 9 y 95 .

- SAVOINI, S.; (2004) La inclusión de la palabra del otro en el discurso informativo. Apunte de la Cátedra de Semiótica II. Universidad Nacional del Nordeste, Corrientes.

- TEUBAL, M. y PALMiSANO, T.; (2010) El conflicto agrario en la Argentina (2008/2010): sojización vs. agricultura familiar de alimentos. Ponencia presentada al VIII Congreso Latinoamericano de Sociología Rural, Porto de Galinhas, páginas 1-3 y 5-8.

- TREW, T.; (1983) Teoría e ideología en acción. En: Fowler, R. (ed.): Lenguaje y Control. Primera Edición. FCE, México.

- ULANOVSKY, C. (1997) Paren las rotativas. Primera Edición. Compañía Editora Espasa Calpe Argentina S.A., Buenos Aires, página 333.

- VAN DIJK, T.; (1997) Racismo y análisis crítico de los medios. Paidos; España.

- VAN DIJK, T.; (2000) Ideología. Gedisa. S.A., Barcelona, páginas 15, 16, 17, 338 y 395.

-VAN DIJK, T.; (2003) Ideología y Discurso. Ariel, Madrid, Capítulo 5.

- VERÓN, E.; (1980) Anais du Primeiro Coloquio de Semiotica, Ediçoes Loyola-PUC, Sâo Paulo-Rio de Janeiro, páginas 85-98.

- VERÓN, E.; (1983) Construir el acontecimiento. Editorial Gedisa, Buenos Aires, 1983. 
-VERÓN, E.; (1985) El análisis del contrato de lectura. En: Les medias: Experiences, recherches actuelles, aplications. IREP, París, páginas 1 a 12.

- VERÓN, E.; (1999) Aniversarios. En: Efectos de agenda; Gedisa; Barcelona.

-VERÓN, E.; (2001) El cuerpo de las imágenes. In: Enciclopedia Latinoamericana de Sociocultura y Comunicación, Grupo Editorial Norma, Buenos Aires, página 14.

- VERÓN, E.; (2002) Construir el acontecimiento. Tercera Edición. Editorial Gedisa, Barcelona Capítulos II y III.

-VERZEÑASSI. D.; (2014) Agroindustria, salud y soberanía. En: Melón, D. ed. La patria sojera. El modelo agrosojero en el Cono Sur. Primera edición. Editorial El Colectivo, Buenos Aires, 31-48.

\section{TESIS}

MELON, D.; (2014) La patria sojera: el modelo agrosojero en el Cono Sur. (Tesis), La Plata, Universidad Nacional de La Plata.

\section{DIARIOS}

HOY, La Plata, Buenos Aires. Edición del 16/05/2004, página 11.

LA RAZÓN, Bolivia. Edición del 22/05/2005.

EL DIARIO, La Paz, Bolivia, 18/05/2005.

LA NACIÓN, Buenos Aires, 02/12/2007, página 6.

PÁGINA 12, Buenos Aires, 30/12/2016, página 16.

\section{REVISTAS}

- ADÁMOLI, J.; (2013) Evolución de las áreas cultivadas en Salta y en Santiago del Estero, 1977-2010. Amanecer Rural. Edición Especial Diciembre No 127- Enero № 128: 109-112.

- AVEllanAl, I., En Acción, Revista de INCUPO, Agosto/ Septiembre de 2014, página 5.

- ARANDA, D.; (2013) Qué campo. Revista MU. Febrero: 14, 15 y 16.

- ARANDA, D; (2013) El árbol y el bosque. Revista MU. Marzo: 18 y 19.

- ARANDA, D; (2013) La postal del modelo. Revista MU. Mayo: 10 y 11. 
- ESCUDERO, L.; (1997) ¿Quién es el autor de las noticias? Revista Sociedad. Número 11.

- FEDEROVISKY, S.; (2014) La soja como problema. Le Monde diplomatique. Mayo de 2014, página 9.

- FONAF, Federación de Organizaciones nucleadas de la Agricultura Familiar; (2013) Los mercados populares: una alternativa a favor de la soberanía alimentaria. Revista Agricultura Familiar. Año 1 No 1 Segunda edición: Página13.

- GALAND, P.; (2014) Especuladores hechos bolsa. Revista Veintitrés, 9 de octubre de 2014.

- JAURETCHE, A.; (1958) La mentira de la “prensa libre”. Revista Qué sucedió en 7 días. Año IV, $\mathrm{N}^{\circ} 173,18$ de marzo de 1958, págs. 10 y 11.

- MARTÍNEZ, N.; (1996) El estudio del discurso periodístico informativo; una aproximación metodológica desde la teoría de la discursividad social. Trípodos. Número 2.

- MOCASE, (2007) Situación crítica de nuestros bosques. Revista Defensa del Monte, No1. Página 14.

- VAQUERO, P.; (2013) Intacta RR2 PRO contribuirá a un sistema productivo más sustentable. Amanecer Rural. Edición Especial Diciembre No 127- Enero No 128: 55 y 56.

- UZIN, M. M.; (1996) El plurilingüismo en Mijail Bajtín: interacción y diálogo de lo oculto, lo masivo y lo popular en una novela de Manuel Puig. Revista Voces e Ideologías.

\section{WEB-BIBLIOGRAFÍA}

- Crónica de la soja en la región pampeana argentina. Fernando Martínez. En: http://inta.gob.ar/documentos/cronica-de-la-soja-en-la-region-pampeanaargentina/at_multi_download/file/cr\% $\%$ C3\%B3nica-de-la-soja-en-la-regi $\% \mathrm{C} 3 \% \mathrm{~B} 3 \mathrm{n}$ pampeana-argentina.pdf

- Declaración de la FAO sobre biotecnología. En: Portal de la Organización de las Naciones Unidas para la Alimentación y la Agricultura. http://www.fao.org/biotech/fao-statement-onbiotechnology/es/

- "Declaración de la Unión de Asambleas Ciudadanas sobre la criminalización y judicialización de la protesta social" www.biodiversidadla.org

- Desertificación, lado escondido del boom granario. En $\underline{\text { www.comambinetal.com.ar }}$ 
- En 2012: 50 Millones de hectáreas de soja transgénica. Berterretche, Juan Luis, 17/09/13. En:http://www.ecoportal.net/Temas Especiales/Salud/En 201250 Millones de Hectareas de Soja Transgenica

- Experta de la FAO: Transgénicos no amenazan integridad medioambiental. En El Diario, La Paz, Bolivia, 18 de mayo de 2005 http://madalbo.blogspot.com.ar/2012/08/experta-de-la-fao$\underline{\text { transgenicos-no.html }}$

- INDEC http://www.indec.mecon.ar/

- La producción de soja en el Cono del Sur: Actualización sobre Uso Suelos y Plaguicidas. Georgina Catacora, Pablo Galeano, Sarah Zanon Agapito, Darío Aranda, Tomás Palau y Rubens Nodari. En: http://www.genok.com/news_cms/2012/july/report-soybean-productionin-the-southern-cone-of-the-americas-update-on-land-and-pesticide-use/158

- La República Unida de la Soja recargada. En: organización internacional GRAIN. http://www.grain.org/es/article/entries/4739-la-republica-unida-de-la-soja-recargada

- Las protestas rurales. Ediciones Incupo. http://redaf.org.ar/wp-content/uploads/2008/04/lasprotestas-rurales.pdf

- "Los orígenes del yuyo maldito", http://edant.clarin.com/suplementos/rural/2008/04/12/r01648969.htm

- La soja finalizó el año con mayor cosecha y exportaciones, aunque los precios cerraron en baja. Por: Juan Gasalla. En: http://www.infobae.com/2013/12/31/1534275-la-soja-finalizoel-ano-mayor-cosecha-y-exportaciones-aunque-los-precios-cerraron-baja

Folleto sobre Semillas Nativas y Criollas del Ministerio de Agricultura, Ganadería y Pesca de la Nación y de la Federación de Organizaciones Nucleadas de la Agricultura Familiar (FONAF).

Foto de tapa. En Urgente 24: http://www.urgente24.com/230816-la-soja-no-da-promesas-para$\underline{\mathrm{el}-2015}$ 
